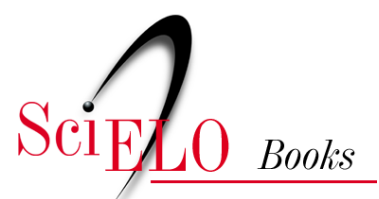

\title{
A ciência como profissão médicos, bacharéis e cientistas no Brasil (1895-1935)
}

\author{
Dominichi Miranda de Sá
}

\section{SciELO Books / SciELO Livros / SciELO Libros}

SÁ, D.M. A ciência como profissão: médicos, bacharéis e cientistas no Brasil (1895-1935) [online]. Rio de Janeiro: Editora FIOCRUZ, 2006, 216 p. História e Saúde collection. ISBN: 978-85-541-308-1. https://doi.org/10.7476/9788575413081.

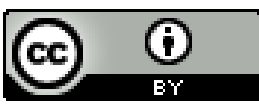

All the contents of this work, except where otherwise noted, is licensed under a Creative Commons Attribution 4.0 International license.

Todo o conteúdo deste trabalho, exceto quando houver ressalva, é publicado sob a licença Creative Commons Atribição 4.0. 


\section{A ciêncía como Profíssão}

médicos, bacharéis e cientistas no Brasil (1895-1935) 


\section{FUNDAÇÃO OSWALDO CRUZ \\ Presidente \\ Paulo Marchiori Buss \\ Vice-Presidente de Ensino, \\ Informação e Comunicação \\ Maria do Carmo Leal}

\section{EDITORA FIOCRUZ}

\section{Diretora}

Maria do Carmo Leal

Editor Executivo

João Carlos Canossa Pereira Mendes

Editores Científicos

Nísia Trindade Lima e Ricardo Ventura Santos

Conselho Editorial

Carlos E. A. Coimbra Jr.

Gerson Oliveira Penna

Gilberto Hochman

Lígia Vieira da Silva

Maria Cecília de Souza Minayo

Maria Elizabeth Lopes Moreira

Pedro Lagerblad de Oliveira

Ricardo Lourenço de Oliveira

Coleção História e Saúde

Editores Responsáveis: Jaime L. Benchimol

Flavio C. Edler

Gilberto Hochman 


\section{A ciêncía como Profíssão}

médicos, bacharéis e cientistas no Brasil (1895-1935)

Dominichi Miranda de Sá

$$
\begin{aligned}
& \text { EDITORA } \\
& \text { FIOCRUZ } \\
& \text { FiOC }
\end{aligned}
$$


Copyright (C) 2006 da autora

Todos os direitos desta edição reservados à

FUNDAÇÃO OSWALDO CRUZ / EDITORA

ISBN: 85-7541-077-6

Capa e projeto gráfico

Angélica Mello, Guilherme Ashton e Daniel Pose

Ilustração da capa

Posse de Oswaldo Cruz na Academia Brasileira de Letras em 26 de junho de 1913, Rio de Janeiro. Acervo da Casa de Oswaldo Cruz, Departamento de Arquivo e Documentação [IOC (OC) 5-4].

Editoração eletrônica

Guilherme Ashton

Supervisão editorial

Janaina S. Silva

Catalogação-na-fonte

Centro de Informação Científica e Tecnológica

Biblioteca da Escola Nacional de Saúde Pública Sergio Arouca

S111c

Sá, Dominichi Miranda de

A ciência como profissão: médicos, bacharéis e cientistas no Brasil (1895-1935). / Dominichi Miranda de Sá. - Rio de Janeiro: Editora Fiocruz, 2006.

216 p. il. (Coleção História e Saúde)

1. Médicos-história. 2. Ciência-história. 3. Ciências da saúde. 4. Ocupações em saúde. 5. História do século 20. I. Título.

$$
\text { CDD - 20.ed. - 362.10230981 }
$$

2006

EDITORA FIOCRUZ

Av. Brasil, 4036 - $1^{\circ}$ andar - sala 112 - Manguinhos

21040-361 - Rio de Janeiro - RJ

Tel.: (21) 3882-9039 e 3882-9041

Telefax: (21) 3882-9006

e-mail: editora@fiocruz.br

http://www.fiocruz.br/editora

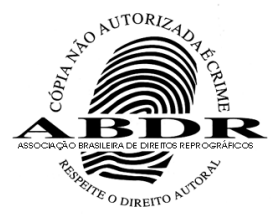


Aos meus pais, Carlito e Marilda, e ao Fernando com todo $o$ amor que houver nessa vida! 



\section{Sumárío}

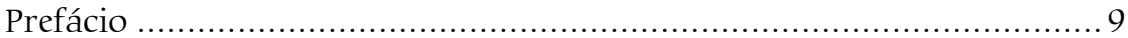

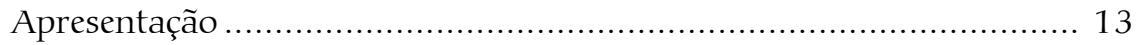

1. Os Intelectuais: história e polêmicas ………….......................... 21

2. A Sociedade Culta da Capital Federal ........................................... 33

3. Entreato: os expoentes da cultura literária ................................... 61

4. A Generalidade em Crise …...................................................... 73

5. Uma Multidão de Idéias Novas .................................................. 89

6. A Crítica da Razão Pomposa ……............................................ 107

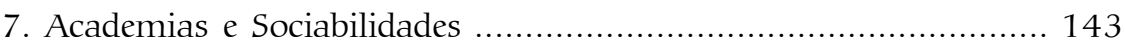

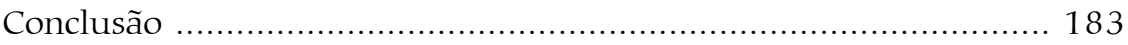

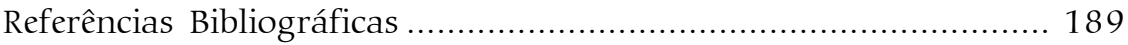

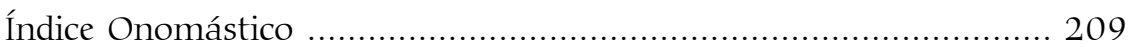




\section{Prefácio}

Venho das últimas gerações da monarquia. Assisti aos cinco anos às primeiras festas da República. Penso que o país deve um grande serviço à minha geração: foi a primeira a descrer das "fabulosas riquezas" do Brasil, para começar a crer nas "decisivas possibilidades do trabalho". Recebemos a noção de que um moço bem nascido e bem criado não devia precisar trabalhar... Ouvimos ainda o eco dos eitos. Diziam-nos que nosso céu tem mais estrelas que os outros... Minha geração começou a contar as estrelas. E foi ver se era verdade que nos nossos bosques havia mais vida. E começou a falar claro aos concidadãos. Com minha geração, o Brasil deixou de ser tema de lirismo.

Roquette-Pinto (depoimento ao periódico Vamos Ler, 23 mar. 1939)

O depoimento de Roquette-Pinto apresenta a auto-imagem professada por sua geração, ressaltando a busca pela afirmação de novas identidades profissionais em um contexto marcado pelo recente passado escravista e colonial. Refere-se também à crítica corrente, e que se estendeu aos períodos que se seguiram aos primeiros anos da República, ao ufanismo e ao que era apontado como tradição retórica e bacharelesca do ambiente intelectual do país no início do século XX.

Tal processo de auto-construção de identidade e imagem pública não foi uma peculiaridade da história intelectual brasileira, como vêm demonstrando importantes trabalhos nos campos da história das idéias e da história das ciências. Entre outras contribuições, destaca-se Entre a Literatura e a Ciência, obra de Wolf Lepenies sobre o processo de especialização do discurso das ciências sociais. Neste texto, o autor refere-se a um estilo intelectual que, para se afirmar, deveria afastar as emoções e a subjetividade, e que contribuiu inclusive para a mudança na conotação da palavra literatura. Esta foi sendo progressivamente alterada - de sinônimo da expressão escrita do conhecimento e da ilustração próprios a diferentes domínios do saber passou a se referir essencialmente à prosa de ficção e à poesia. Questão semelhante pode ser apontada para o conjunto das ciências, com a progressiva padronização de linguagem, conceitos e estilos de trabalho, verificando-se simultaneamente a especialização do conhecimento 
e a afirmação da autonomia da categoria cientista nos mais diferentes contextos nacionais.

O estudo desse processo no caso do Brasil ganha agora novas luzes a partir deste admirável livro de Dominichi Miranda de Sá. A autora analisa a especialização do trabalho científico e a afirmação do cientista como categoria profissional nas três primeiras décadas do século XX, com ênfase na geração que criou em 1916 a Academia Brasileira de Ciências. Em destaque, as campanhas voltadas para a valorização da ciência e de seu papel, no que se entendia como processo civilizatório e de construção nacional, empreendidas por personagens como Edgard Roquette-Pinto, Henrique Morize, os irmãos Miguel e Álvaro Ozório de Almeida, Alberto Paes Betim Paes Leme, Oswaldo Cruz, Carlos Chagas, Cardoso Fontes e Juliano Moreira - todos vinculados a importantes movimentos intelectuais e políticos e à criação de instituições científicas cuja trajetória representa importante, mas ainda pouco estudada, face da história do Brasil republicano.

A Ciência como Profissão apresenta consistente análise em que sobressai a relação tensa, mas não necessariamente antagônica, entre cientificismo e humanismo. A abordagem escolhida privilegia as vertentes mais criativas da história das idéias e dos conceitos, o que se evidencia tanto nos capítulos de discussão teórica e cotejamento com a experiência européia quanto nos que se dedicam ao estudo do processo de especialização da categoria social do cientista no Brasil. Entre os pontos fortes do livro, destaca-se a compreensão de como, em alguns contextos culturais, coube aos próprios cientistas a crítica ao otimismo científico e à associação entre inovação tecnológica e progresso social.

No caso do Brasil, a despeito da valorização positiva do papel dos intelectuais/cientistas, evidencia-se, como um dos aspectos mais problemáticos de seu legado, o processo de construção da imagem que associa tradição retórica e origem ibérica, proposta, pelo menos desde fins do século XIX, por intelectuais como Sílvio Romero e reforçada pelos cientistas do início do século XX. Tal interpretação foi amplamente divulgada em estudos clássicos da história das ciências, como nas obras de Fernando de Azevedo, e fixou-se na matriz de análise que, ao longo de décadas, postulou a coincidência entre a criação das universidades nos anos 1930 e o efetivo desenvolvimento das ciências e do espírito científico no Brasil, tese que começou a ser mais fortemente questionada na década de 1980 pelas novas tendências historiográficas.

Ao mesmo tempo em que se acentuava a importância da explicação científica para os problemas do país, verificava-se a presença dos cientis- 
tas nos espaços de consagração destinados prioritariamente aos literatos e ensaístas. Nessa perspectiva, a leitura do sétimo capítulo deste livro traz importante contribuição, ao se deter nas polêmicas que marcaram o ingresso na Academia Brasileira de Letras de médicos/cientistas, como Oswaldo Cruz, Miguel Couto, Aloísio de Castro e Roquette-Pinto. Nesse mesmo capítulo, são analisados outros espaços de consagração e sociabilidade acadêmica, como o Instituto Histórico e Geográfico Brasileiro (IHGB) e a Academia Brasileira de Ciências. Ao lado da análise das características que diferenciavam tais espaços, identificam-se alguns projetos que ainda não mereceram maior atenção nos estudos históricos. É o caso da proposta apresentada em 1911, no IHGB, de criação da 'Universidade Brasileira', integrando o ensino das ciências e das letras.

No decorrer da leitura, constatamos também que o ensino universitário e a reforma educacional em sentido amplo foram temas privilegiados pela Academia Brasileira de Ciências, cujos integrantes lideraram muitos projetos e a criação da Associação Brasileira de Educação, em 1924. Ao estabelecer relações entre os espaços de sociabilidade e consagração intelectual nas três primeiras décadas do século XX e a formulação de projetos de reforma ou criação institucional, a autora contribui para o estudo de diferentes temáticas da pesquisa histórica, entre elas a história da educação no Brasil.

Outro ponto forte desta obra consiste na contribuição, ao mesmo tempo, para os estudos de história da ciência e da divulgação científica. Isto tanto no que se refere à análise do papel que assumiu a Academia Brasileira de Ciências nos esforços de "vulgarizar a ciência" - entre os quais se destaca a criação da Rádio Sociedade do Rio de Janeiro, em 1923 - quanto às evidências apresentadas para um argumento ainda não suficientemente abordado pelos estudiosos do tema. Trata-se da estreita e, à primeira vista, paradoxal relação entre a progressiva especialização do discurso científico e a intensa atividade de divulgação ou "vulgarização científica".

Pode-se dizer também que a especialização do discurso científico entre nós foi acompanhada pela defesa da ciência como chave interpretativa da cultura brasileira, o que resultou muitas vezes em um cientificismo humanista, como bem ressaltou Roque Spencer Maciel de Barros em seu $A$ Ilustração Brasileira e a Idéia de Universidade. Para este autor, o cientificismo humanista ancorava-se em filosofias da história que professavam a crença no progresso das sociedades humanas e que, ao insistirem na identidade humana e no determinismo histórico universal, desautorizaram as interpretações pessimistas sobre o futuro do país. 
Cientistas, mas também intérpretes e construtores da cultura e reformadores sociais, com sua aposta em políticas públicas nas áreas de saúde e educação - estas são as principais características da geração que criou, entre outras instituições a Academia Brasileira de Ciências. O estudo de suas estratégias discursivas, de sua atuação e papel na cultura brasileira ganha nova dimensão com a análise empreendida por Dominichi Miranda de Sá. Certamente este livro inspirará novos estudos que caminhem na direção oposta ao que uma leitura mais apressada do processo de especialização da categoria social do cientista no início do século XX poderia apontar. Trata-se de estabelecer as necessárias pontes entre história das idéias e história das ciências; entre discurso científico e o pensamento social e político no Brasil.

Nísia Trindade Lima Pesquisadora da Casa de Oswaldo Cruz (COC) e editora científica da Editora Fiocruz 


\section{Apresentação}

Na linguagem culta da Corte Imperial, a expressão 'literatura' significava a soma dos saberes cultivados pelos então chamados 'homens de letras'. A palavra funcionava na ocasião como um sinônimo de 'conhecimento e instrução', englobando a oratória política, a medicina, o direito, a filosofia, as letras, a ciência, a eloqüência, a gramática, a filologia, a história e as humanidades. Era o nome pelo qual se fazia menção ao movimento das idéias no Brasil oitocentista. ${ }^{1}$

Versados em literatura porque conhecedores de vários ramos do saber, os homens de ciência, jornalistas, artistas, médicos, advogados, bacharéis, historiadores e poetas eram, por exemplo, literatos. Seus demais atributos e significados pares mais imediatos eram ainda 'homens de espírito', de 'letras', 'eruditos', 'intelectuais', 'letrados', 'doutos', 'ilustrados', 'sábios' e 'instruídos'.2

Nesse período, a 'literatura', nela incluídas a 'retórica' e as 'humanidades', era o saber que contribuía para a formação pessoal; com o seu aprendizado, os letrados supunham esclarecer a sua inteligência. ${ }^{3}$ E eles eram especialmente bem vistos e respeitados por reterem na memória conhecimentos gerais bastante variados - numerosas referências, línguas e teorias estrangeiras, passagens de livros e máximas de autores, sobretudo, os da Antigüidade Clássica. Vultuoso cabedal que costumavam exibir em discursos, aulas, odes cívicas, sermões e conferências públicas. Partidários 
de um Iluminismo tardio que lhes incutia acentuado entusiasmo pela ampla difusão do saber, reconheciam-se ainda como homens especialmente aperfeiçoados e, por isso, inclusive, dotados de autoridade para fazer progredir toda a sociedade. Atuação civilizadora que estenderam à tarefa de delimitar os fundamentos da própria identidade nacional no então recém-implantado Estado brasileiro. Nessa época, a atividade intelectual não constituía uma ocupação profissional, sendo considerada uma missão espinhosa, mas benemérita e muito nobre. Em suma, era nada menos do que um sacerdócio ou um apostolado.

No entanto, em fins do século XIX, a intelectualidade começou a se especializar. Nesse novo cenário, a vasta instrução perdeu grande parte do seu prestígio público, adquirindo, no mesmo movimento, ares de cultura enciclopédica 'inútil'. A carreira nas letras esmerou-se na composição de obras de poesia e romances. Homens de ciência ganharam respeitáveis ares públicos de experimentação e observação da 'realidade'. A palavra 'literatura' começou a adquirir uma nova significação - a de 'arte de ficção' -, perdendo, gradualmente, a sua estreita aproximação semântica com as 'humanidades' e com a idéia de 'conhecimento'. ${ }^{4}$ A 'cultura geral' tornou-se uma 'frívola' manifestação de pompa verbal, enciclopedismo, beletrismo, bacharelismo, verborragia e vaidade intelectual. As leituras de salão, as conferências literárias e o cultivo de um saber ligado à oralidade culta começaram igualmente a decair. Aos olhos da elite letrada fortaleceu-se a convicção de que o exercício de uma atividade profissional específica deveria ser, então, a razão primordial da dedicação aos estudos.

Sucede que todas essas mudanças nos juízos pelos quais os letrados do período firmavam os seus critérios de reconhecimento intelectual não se deram sem resistências, mútuas acusações, inúmeros debates, posicionamentos incongruentes e grandes hesitações. E a esse respeito, o caso aqui proposto é exemplar. O objeto central deste livro é a análise das mudanças nos estilos de produção cultural na virada do século XX. Examina-se, na verdade, o processo de especialização da atividade intelectual, tomando como foco privilegiado da investigação a emergência do 'cientista'. Trata-se de compreender o seu surgimento como o profissional da pesquisa aplicada e como uma das vozes mais ativas na crítica à 'pompa enciclopédica' e na defesa de um padrão mais especializado de formação e produção intelectuais.

O livro vincula-se a uma tendência contemporânea de revisão da história da atividade científica no Brasil. A respeito, deve-se mencionar que a introdução da prática experimental em laboratórios foi por muitas décadas o critério de validação obrigatório para identificar os primórdios do 
exercício científico no país. De acordo com essa interpretação, o Instituto de Manguinhos teve a total primazia como centro irradiador da ciência no Brasil. No entanto, não teria passado de um esforço isolado na paisagem intelectual dos primeiros anos do século XX, já que seguido num larguíssimo espaço de tempo pelas universidades, fundadas na década de 1930.

Nessa análise, a extensa precariedade institucional vivida até os anos 30 é vista como um correlativo lógico tanto da atuação nacionalista dos intelectuais quanto da sua forte ligação com o Estado. E enquanto essa produção intelectual teria sido ainda panfletária, ensaística, eclética teoricamente e indefinida do ponto de vista disciplinar, as universidades teriam representado a instauração automática de uma nova epistème. Como sua decorrência, a implementação da especialização entre as várias áreas do conhecimento, método incorporado ao trabalho científico imediatamente após a criação dos departamentos, cadeiras e disciplinas universitárias (Stepan, 1976; Schwartzman, 1979; Ferri \& Motoyama, 1979; Cunha, 1980; Miceli, 1989, 1995; Azevedo, 1994).

Nos últimos anos, as pesquisas em história das ciências redimensionaram tais demarcações temporais e, sobretudo, investigaram outros espaços de atuação intelectual e o seu papel no desenvolvimento conceitual e no fortalecimento da prática científica no Brasil. Nesses estudos foram contemplados os periódicos médicos, as conferências populares, os jardins botânicos, as escolas médico-cirúrgicas, os institutos agrícolas, os museus naturais, as comissões, expedições e associações de caráter científico existentes no país desde o período colonial (Alves, 1989; Domingues, 1995; Ferreira, 1989, 1996; Lopes, 1997; Lima, 1999; Edler, 1999; Benchimol, 1999; Fernandes, 2000). ${ }^{5}$ A vertente é muito promissora e inovou a historiografia das ciências, já ansiosa de novo fôlego dada a longa vigência do paradigma universitário. Com essa reformulação interpretativa, a geração de cientistas das primeiras décadas do século XX deixou corretamente de ser considerada como precursora da ciência no Brasil, mas foi inserida numa tradição de pesquisas que remontava a muitas décadas antes da sua aparição no cenário intelectual.

No entanto, marca forte no discurso dos cientistas da época é a insistência na singularidade da sua atuação, instauradora, no seu dizer, de uma verdadeira ruptura com antecessores e tradições culturais. ${ }^{6}$ Como se procura demonstrar no livro, não inauguraram a atividade científica, mas representaram efetivamente uma variação nos modos de se produzir idéias no país. A grande novidade da sua agenda foi a defesa da especialização intelectual como o mais seguro caminho para a prosperidade do trabalho científico brasileiro e sua equiparação internacional. Reconhecer esse de- 
bate reforça a crítica ao paradigma institucional e consolida a nova vertente na historiografia das ciências. A institucionalização universitária deve ser interpretada como o remate do processo de especialização dos saberes e da individualização crescente das disciplinas, e não como o seu nascimento. Representam, na verdade, a enorme relevância que essas especializações já possuíam no âmbito da atividade científica brasileira.

A demarcação temporal privilegiada procura abarcar os períodos de formação e atuação profissional da geração de cientistas brasileiros que debateu a especialização intelectual, e rejeitou, no mesmo movimento, os qualificativos de 'retóricos', 'enciclopédicos' e 'homens de letras' - vocábulos que empregavam tanto para desqualificar a produção intelectual generalista que lhes antecedera quanto para designar os autores de ficção que lhes eram contemporâneos. E é por isso, inclusive, que a identidade do 'cientista' vai-se construindo em oposição à imagem do 'literato'.

Nos discursos científicos, literatos seriam todos os 'diletantes' e 'polivalentes', ocupados com a beleza da forma e com o agrado aos mais variados gostos. Na sua crítica aos intelectuais enciclopédicos, os cientistas repreendiam indistintamente a pretensa inutilidade social dos 'homens de letras' e dos 'eruditos', dos 'autores de ficção' e dos 'retóricos'; afinal, no seu dizer, todos não faziam mais do que 'literatura', ou seja, ou não faziam mais do que 'cultivar a instrução', ou ocupavam-se tão-somente em 'burilar ilusões com a expressão oral e escrita'.

A ambigüidade do emprego desses termos denota o emaranhado dos significados disponíveis naquele período - entrecruzavam-se os que teimavam em não desaparecer e aqueles que se iam impondo na linguagem corrente dos intelectuais. A polissemia de determinadas categorias - como 'retórica' e 'literatura', por exemplo - e a ausência de uma unidade de sentido para o seu emprego são reconhecidas como pistas valiosas da adoção de um novo estilo de produção cultural.

E para interpretar essas inflexões na intelectualidade do período, toma-se para exame as revistas ilustradas, os estatutos, atas, periódicos e discursos feitos nas academias literárias e sociedades científicas, assim como ainda os artigos publicados pelos (e sobre os) cientistas nos jornais e revistas de ciências e letras da cidade do Rio de Janeiro, à época centro político e intelectual do país e seu maior pólo comercial e populacional. Em detrimento dos livros, tais artigos foram privilegiados porque é preciso, quanto a isso, levar em conta as dificuldades na impressão tipográfica e a lentidão na distribuição dos volumes, o que conferia à imprensa periódica grande importância literária, por seu trânsito e ampla circulação serem consideravelmente mais rápidos e por seus produtos serem, inclusive, mais 
baratos. Ademais, eram utilizados como veículos privilegiados para o debate científico desde o século XIX (Ferreira, 1996; Figueirôa \& Lopes, 1997; Benchimol, 1999).

Nesse período, a presença dos temas científicos era bastante intensa nos jornais diários e nos semanários que circulavam no Rio de Janeiro. Figuravam nas chamadas de primeira página, em artigos, editoriais, seções e números especiais. A imprensa noticiava as novas descobertas científicas, as viagens dos cientistas ao exterior, a presença de cientistas estrangeiros no país, suas biografias, perfis e obituários, e ainda costumava realizar entrevistas e reproduzir as palestras, as aulas e os discursos proferidos nas mais prestigiadas instituições da época. E tudo isto graças à importância então conotada à ciência no processo de modernização e civilização do país.

Nessas fontes foram levantadas as mudanças no vocabulário descritivo da atividade científica, com análise do recurso aos léxicos utilizados para designar as suas novas idéias, práticas, escrita e especialidades. Nos artigos publicados nas revistas dedicadas a um público letrado mais amplo, percebese um nítido voluntarismo dos cientistas em explicitar os novos padrões de identidade intelectual - pontos que pretendiam firmar publicamente. E nesse caso, se desejavam tornar públicas as suas respectivas atribuições e características, tais veículos eram perfeitos. Muito mais adequados, aliás, que as revistas médico-científicas, em que, na verdade, apresentavam os resultados de suas pesquisas e reflexões sem discutir ou contra-argumentar as normas e códigos de conduta da atividade científica. ${ }^{7}$

O livro constitui-se em sete capítulos. No capítulo 1, discute-se o tratamento dado ao tema pela historiografia brasileira, relacionando-o à proposta dessa pesquisa. No capítulo 2 , identifica-se a agonia da imagem pública do 'homem de letras' de espírito erudito e generalista, representação cada vez mais estereotipada no discurso intelectual do período. Essa marcante descaracterização do letrado tradicional pode ser acompanhada, nas revistas e jornais, pelas duras críticas ao 'estilo retórico' que grassaria, então, nas rodas intelectuais da Capital Federal. Nessa época, irromperam as maiores inventivas contra toda sorte de bacharelismo, exemplo mais bem acabado do intelectual enciclopédico amante da erudição ostentosa e da palavra sonora.

Expõe-se, em linhas gerais, no capítulo 3, o momento de consolidação de um discurso em defesa da profissionalização dos literatos como prosadores e autores de obras de ficção. No capítulo 4, mapeando os combates iniciados na imprensa carioca contra as belas-letras, o bacharelismo e seu imenso prestígio social, passa-se a associá-los à importância da 
separação entre as áreas do conhecimento. Trata-se ainda das inter-relações entre as mudanças na cidade do Rio de Janeiro e as transformações nas maneiras de 'se ilustrar' e produzir intelectualmente, com breve discussão da legislação do período sobre instrução pública.

No capítulo 5, discute-se o panorama internacional ao qual se filiou o discurso científico aqui tomado como objeto, identificando os gêneros, os paradigmas analíticos e os modelos de produção intelectual com os quais os cientistas dialogaram no seu lento processo de especialização. No capítulo 6, analisa-se a circulação dessas idéias nos meios intelectuais brasileiros. Nessa textualidade, a adoção do modelo especializado era indissociável da refutação da ascendência ibérica sobre a cultura nacional. No seu dizer, o 'peso da retórica' seria fruto da tradição cultural clássica e literária herdada de Portugal. E a ela os cientistas contrapunham a defesa da 'ciência' - a imagem da 'civilização' e da 'modernidade' - e seus demais elementos pares, tais como a padronização conceitual, o emprego da evidência empírica e da prova, a importância da observação e do experimento, a adoção da técnica, do parcelamento das atividades profissionais e de uma pedagogia da disciplinarização do tempo de trabalho.

No último capítulo, através das atas das reuniões da Academia Brasileira de Ciências $(A B C)$ e do Instituto Histórico e Geográfico Brasileiro (IHGB), assim como dos acervos pessoais dos cientistas e dos discursos de posse e recepção na Academia Brasileira de Letras (ABL), examinam-se os seus múltiplos vínculos intelectuais e demais modos de sociabilidade em associações literárias que consideravam tradicionais, mas às quais teimavam em pertencer. A maneira como eram confrontados, sobretudo, na imprensa carioca, pela sua suposta incoerência intelectual ajuda a compreender o lento processo de assentamento das suas especialidades profissionais. Discute-se, por fim, as demandas pela criação de universidades e faculdades de ciências no Brasil e as inter-relações entre as suas atividades como divulgadores e postulantes à especialização científica.

Essas iniciativas foram assumidas por parte dos cientistas ligados a três das maiores instituições científicas brasileiras do período: a Escola Politécnica, o Instituto Oswaldo Cruz (IOC) e o Museu Nacional (MN). Toda essa discussão, no entanto, ultrapassa as suas filiações institucionais, engajando-os em um movimento de defesa de uma imagem profissional distinta das demais atividades intelectuais. Não há neste livro análise minuciosa das suas biografias e obras - os cientistas são citados de acordo com a sua contribuição e mobilização para o debate. E esses intelectuais dentre os mais destacados, Edgard Roquette-Pinto, Miguel Ozório de Almeida e seu irmão Álvaro, Alberto Betim Paes Leme, Oswaldo Cruz, Carlos Chagas, 
Aloísio de Castro, Juliano Moreira - procuraram marcar a sua enorme desconexão com o passado. Glorificaram a inauguração de uma nova era para a realização dos trabalhos científicos no país: seu maior símbolo foi a fundação da $A B C$ em 1916. As renovações epistemológica, lingüística e temática que atribuíram à sua geração são fundamentais para se compreender a nova identidade profissional que pleiteavam para a ciência no Brasil.

Este livro é uma versão revisada da minha tese de doutorado defendida em 2003 no Programa de Pós-Graduação em História Social da Universidade Federal do Rio de Janeiro (PPGHIS-UFRJ). Muitas pessoas e instituições contribuíram, de diversas maneiras, no trajeto da tese ao livro. A elas, gostaria de agradecer brevemente.

O orientador da tese, o professor Afonso Carlos Marques dos Santos, não pôde vê-la publicada. Registro aqui, além da minha saudade, que nosso vínculo foi um estímulo fundamental não só para que eu chegasse ao fim deste trabalho, mas para que nunca perdesse a confiança. Agradeço à Capes que me concedeu bolsa de doutorado por quatro anos e bolsa-sanduíche para freqüentar a École des Hautes Études en Sciences Sociales de Paris. Agradeço ao professor François Hartog por sua disponibilidade, interlocução e ricas sugestões para esta pesquisa. Agradeço também a todos os colegas, funcionários e professores do PPGHIS, e especialmente aos professores Eliana Regina de Freitas Dutra, Nísia Trindade Lima, André Luiz Vieira de Campos e Manoel Luiz Salgado Guimarães pelos comentários e indicações valiosas na defesa da tese.

Devo uma menção especial à Nísia Trindade Lima por sua generosidade, incentivo, respeito intelectual e entusiasmo. A marca da nossa convivência é bem nítida neste trabalho.

Agradeço ainda aos funcionários da Biblioteca Nacional, da Fundação Casa de Rui Barbosa, do Centro de Memória da Academia Brasileira de Letras, da Academia Brasileira de Ciências e sobretudo aos colegas e funcionários da Casa de Oswaldo Cruz pelo excelente clima intelectual. A Gilberto Hochman, caríssimo editor, agradeço pela diligência em ver publicado o livro e pelo preciso título que substituiu a 'pompa retórica' que nomeava a tese.

Registro meu reconhecimento a todos os meus amigos e familiares, e a Luciana Miranda de Sá, minha irmã, e Jonison Lopes Cardoso, meu cunhado, pela alegria constante. Aos dois últimos devo a linda e querida Alice, meu "não contentar-se de contente". Sou profundamente agradecida aos meus pais, Carlito Andrade de Sá e Marilda Miranda de Sá. Não tenho palavras para retribuir apoio tão amoroso. 
Ao fim, agradeço a Luiz Fernando Almeida Pereira. Nossos muitos sonhos deram sentido a todo este trabalho que me parecia interminável.

\section{Notas}

1 Cf. Couto (1842: 239); Vieira (1871: 1326, v.3); Figueiredo (1899: 53, v.2).

2 Cf. Couto (1842: 20, 93, 232, 239); Vieira (1871: 238, 1134, 1292, v.3); Figueiredo (1899: 163, 368, 463, 528, 765, v.1; 1899: 42, 53, v.2).

3 Cf. Couto (1842: 199, 239, 337); Vieira (1871: 238, 992, 1326, v.3; 1871: 292, v.5; Figueiredo (1899: 712, 763, 765, v.1; 1899: 53, 464, 485, v.2).

4 Em dicionário do século XX, a noção já tinha adquirido o seu sentido de 'arte' (Freire, 1954: 3209, v. 4). A 'retórica', de sua parte, viu esvaziar por completo a significação de 'elocução' para ganhar um conteúdo forte de "discurso brilhante na forma embora pobre de idéias. Estilo empolado e guindado. Afetação da eloqüência" (Freire, 1954: 4445-4446, v.5).

5 Como balanço dessa perspectiva de análise em história das ciências, devem-se consultar também os pioneiros textos de Maria Amélia Dantes (1988, 1996, 2001a, 2001b), que, desde a década de 1980, vêm ressaltando a importância em relacionar a história da ciência à história social.

6 À semelhança dos antropólogos, os historiadores têm feito crescente uso das 'categorias nativas', ou melhor, têm incorporado as histórias narradas pelos homens do passado às suas próprias narrativas (Burke, 2000).

7 Nos periódicos Brasil Médico, Revista da Escola Politécnica, Memórias do IOC e Arquivos do Museu Nacional, por exemplo, publicavam-se prioritariamente artigos com considerações sobre temas como medicina, cirurgia, medicina legal e alienação, eugenia, neurologia, oftalmologia, medicina tropical, higiene pública e profilaxia, saneamento, ginecologia, pediatria, ortopedia, receituários médicos, virologia, helmintologia, biologia, química, parasitologia, protozoologia, matemática, astronomia, física, anatomia patológica, hematologia, micologia, clínica geral, entomologia, bacteriologia, zoologia, botânica, fisiologia experimental, paleontologia, geologia, antropologia física, arqueologia e imunologia. E, pela prevalência destes assuntos nas suas páginas, foram preteridos na pesquisa. 


\section{Os Intelectuaís: históría e polêmicas}

Nada muda mais rapidamente do que o imutável passado. Alexandre Koyré (1991)

Abrem-se as cortinas. Vê-se um palco onde inúmeras pessoas se apresentam à vista de uma atenta platéia. Ao entretê-la, desempenhando seus papéis, tentam dirigir as impressões que os espectadores possam ter delas. Empregam técnicas que garantem o seu bom desempenho, e representam, tais como os melhores atores entre todos, os seus personagens diante do público.

Nesse imenso teatro que é a vida em sociedade, as máscaras, as figuras dramáticas, as palavras empregadas e as imagens simuladas constituem um primoroso jogo de comunicação, no qual o que se manipula e controla é a própria espontaneidade da conduta (Goffman, 1995). E tudo isto porque na vida social a encenação tem valor de face - um 'indivíduoator', ao projetar sua figura e suas características pessoais, define-se aos olhos dos seus semelhantes. Em suma, informa o que é. E na vida social, atitudes e convicções, padrões de linguagem e de comportamento, expressões faciais e gestos corporais devem se combinar adequadamente. Em outras palavras, não se pode pretender ser o que não se aparenta, sob pena de um indivíduo não gozar adequadamente do status que o seu tipo social representa publicamente.

Os maiores letrados brasileiros da virada do século XIX para o XX apresentaram-se num 'palco' cujo cenário estava prestes a se transformar 
por completo. De Rui Barbosa a Miguel Ozório de Almeida, passando por Oswaldo Cruz, Roquette-Pinto, Euclides da Cunha, João do Rio e Afrânio Peixoto, nenhum deles deixou de participar do 'espetáculo'. Foram contemporâneos na mesma cidade que, então, começava a se modernizar, tendo sido, todos, eleitos para a mesma, a maior, e a mais prestigiada associação intelectual do período, a Academia Brasileira de Letras (ABL).

Nesse 'palco', houve um tempo em que Rui Barbosa era imbatível, tendo sido aclamado como o maior 'ator' entre todos, ou ainda como a maior inteligência entre todas do planeta. Dominava a 'arte de bem dizer' e de encantar o público com palavras tão sonoras e períodos tão bem decorados que parecia mesmo querer arrebatar o espírito dos auditores que o apreciavam embevecidos. No período em que reinava Barbosa, Oswaldo Cruz, por exemplo, não fazia 'apresentações'. Não dominava a técnica de exibição em público. Não era orador, não possuía vasta memória. Não era talhado, nem formado para esse tipo de encenação pública. Não 'tinha tempo'; aliás, preferia dedicar-se com exclusividade à figura dramática que 'tinha escolhido' para si. No mais, à vista de Barbosa, seria considerado limitado pelo público, por suas falas serem muito específicas e por sua exibição ser tão esotérica. No entanto, no tempo em que Oswaldo Cruz foi aclamado como ator de um só personagem - o 'Pasteur brasileiro' -, Barbosa já era alvo das maiores caçoadas, pela pretensa inutilidade das peças inteiras que levava à mente. A platéia passava a desconfiar de tamanha boa memória, insistindo em saber do préstimo dos saberes desfilados ao palco.

Nesses tempos, Oswaldo Cruz pretendia reinar nas 'composições de ciência', assim como pretendiam se notabilizar Coelho Neto e João do Rio nas 'composições de literatura'. De Euclides da Cunha e Afrânio Peixoto, por exemplo, não se tinha muita clareza quanto ao papel que representavam, quanto aos textos que entoavam, as máscaras que empunhavam e as peças que encenavam. Atores polivalentes, cambiando suas diferentes máscaras, tinham cada vez menos lugar nesse palco. O câmbio de imagens já era tão postiço, era adorno tão artificial, e a apresentação tão sem encanto. Parte dela era gasta em vastas explicações e justificativas sobre suas novas e provisórias vestimentas. Qual a mágica em apresentações nas quais personagens e figurinos estão separados? Nas quais os atores precisam pedir mil licenças para empunhá-los? E o público, ainda que, por respeito, os aplaudisse em novas representações, não lhes perdoava a traição cênica, e já no dia seguinte poder-se-ia notar o alarido de boca em boca. 
Fechem-se as cortinas. Passemos ao enredo da nossa história.

Ela começa num tempo em que coexistiram tanto 'velhos' critérios de reconhecimento intelectual e 'novos' modelos de expressão das idéias quanto ainda 'velhos' tipos sociais e 'novas' definições da atividade criadora. E nessa confluência entre papéis e atores, temos os intelectuais que, por força da análise, são chamados de 'enciclopédicos' - os letrados formados segundo uma educação humanista pretendente a promover-lhes o cultivo da mente e do espírito. 'Bacharéis' ou 'doutores' que, de acordo com o sentido da época, eram todos os diplomados em ciências e letras pelos colégios secundários, como, por exemplo, o prestigiado Colégio Pedro II no Rio, sem esquecer ainda os egressos das escolas superiores de direito, medicina e dos cursos científicos da Escola Politécnica e da Escola Militar, seguindo carreira na política, no funcionalismo público, na magistratura, na advocacia, na diplomacia, na engenharia civil, de minas, de artes e manufaturas, na clínica terapêutica e no magistério.

Nos seus estudos, aprendiam filosofia, letras, matemática, aritmética, geometria, física, química, história natural, latim, grego, línguas estrangeiras e poética, sem contar ainda a retórica. Indissociável dessa educação humanista, a retórica constituía, segundo o conceito tradicional, a 'ciência' da organização e transmissão dos pensamentos, contribuindo para ensinar, argumentar, deleitar e persuadir (Venâncio Filho, 1982; Broca, 1991; Carvalho, 1998; Coelho, 1999).

Temos também os 'especializados' - os diplomados nas mesmas instituições e segundo os mesmos modelos culturais, mas que estavam, então, a pleitear a associação entre formação intelectual e atividade profissional. Sentiam-se filiados a uma outra tradição de pensamento em nome da qual desprestigiavam e ironizavam os velhos tipos sociais. O sarcasmo era, na ocasião, um dos recursos discursivos mais utilizados para decretar o ocaso dos bacharéis, homens de letras, eruditos, retóricos e afins. Em suma, de todos aqueles que, pelo saber acumulado, iam sendo identificados como 'antimodernos'.

Estes enfrentaram verdadeira campanha difamatória na imprensa periódica da Capital Federal. Novos tipos sociais buscavam galardão e notoriedade públicas. Técnicos, especialistas e intelectuais amparados pela dedicação ao ofício, por atestados meritocráticos e por competitividade profissional não lhes perdoavam as pretensas 'frases feitas', inúteis exemplares de um tempo supostamente acabado. Suas leituras variadas nem 
mais serviriam para 'cortejar moças'. Os responsáveis pelas críticas? Conheceremos seus precursores nos capítulos seguintes.

\section{Os Intelectuais e sua História}

A história intelectual experimentou considerável ostracismo no século XX. Por muitos, foi vista como um cruzamento entre a história política e a biografia, exiladas, desde a Escola dos Annales, do campo disciplinar do conhecimento histórico. No apogeu de uma abordagem socioeconômica e num universo onde os problemas sociais foram alçados à categoria de "únicos problemas históricos realmente significativos", as 'massas', os 'vencidos' e as coletividades figuraram como os temas por excelência da história (Darnton, 1990: 176); enquanto os intelectuais, entendidos como expressão da consciência ou como 'elite', foram "confinados ao purgatório dos seus subobjetos" (Sirinelli, 1986: 235). Insuflada pelo desprezo acadêmico, a abordagem apresentada por Arthur O. Lovejoy, em 1936, no seu livro The Great Chain of Being, sustentou por muitos anos a disciplina, confirmando o entendimento da produção intelectual como o fruto de 'mentes privilegiadas' para o pensamento. Obras intelectuais foram, por décadas, entendidas como projetos livremente concebidos pelos autores, tidos como determinantes na criação das idéias (Pomian, 1999). Em outros termos, não passariam de "inteligências desencarnadas". ${ }^{1}$ Assim, até os anos 1980, a história intelectual foi insistentemente 'acusada' de desconsiderar por completo o contexto social (Darnton, 1990). Culpada de ser, ao mesmo tempo, tema, objeto e método e de manifestar preferência por questões periféricas e supérfluas, optando pelo estudo do 'inverso do vivido', ou seja, as idéias e o simbólico, no lugar das chamadas 'condições concretas da existência' (Darnton, 1986, 1990).

A história intelectual foi ainda protagonista de uma confusão semântica que atingiu a definição do seu próprio objeto. Historiadores de diferentes países atribuíram-lhe designações distintas, o que impediu um consenso mínimo em torno do seu tema de trabalho. Para os americanos, por exemplo, a disciplina poderia ser chamada tanto de Intellectual History, quanto de History of Ideas, cada uma delas com a sua área particular de investigação. Para os alemães, seria a Geistesgeschichte, enquanto na França não passaria de a Histoire des Intellectuels. Assim, ao passo que cada comunidade de historiadores imputou à disciplina um nome diferente, 
acabaram também por desenvolver diferentes conceitualidades e métodos para objetos não menos distantes (Chartier, 1990).

Some-se a essas divergências a enorme polissemia do próprio termo 'intelectual'. O significado do vocábulo, tal como o concebemos hoje, guarda uma origem não muito recente. Seu sentido, forjado durante o Iluminismo, manteve uma visão aristocrática de mundo, própria do Antigo Regime, mas já quando a nobreza deixava de ser entendida como uma condição herdada para ser pensada como a aquisição de atributos e qualidades especiais fundadas na autoridade da Razão. ${ }^{2}$ Envolvido na instauração de uma 'república pedagógica', entendida como um projeto, e numa atividade específica, o conhecimento, encontrava-se o 'sábio', ou o philosophe, tornando o funcionamento do universo mais transparente, e, mais do que isso, pondo a razão a serviço da humanidade. E Razão como sinônimo de virtude, de pensamento claro, de busca progressiva de objetividade e neutralidade, mas, fundamentalmente, de crítica. A atividade que consistia, de um lado, em alcançar, pelo conhecimento, resultados justos e corretos; de outro, em combater a ignorância e o erro. A República de Letras ilustrada era uma nova 'elite' com uma autoconsciência muito peculiar - a de educadores de uma nova sociedade e a de representantes da verdade e da humanidade (Charle, 1990; Koselleck, 1990a).

E essa referência teórica nascida na Ilustração, seu aristocratismo letrado, seus hábitos, características mentais e a atuação no espaço público estão na origem do sentido da palavra 'intelectual'. É herança ilustrada a imagem do sábio cuja participação nos grandes problemas sociais é percebida como indício de uma atitude civil e interessada no progresso das Luzes. Na formulação contemporânea, inclusive, reconhece-se o intelectual como um criador cultural na medida em que ele pode ser, no seu engajamento cívico, identificado ao patriota. Essa imagem tanto quanto essa auto-representação consolidaram-se mais ainda, em fins do século XIX, com o célebre Affaire Dreyfus, na França, quando nasceu o sentido recente da palavra - o de homens que participam da resolução de uma questão pública por seu engajamento político. ${ }^{3}$ Desde então, intelectuais passaram a ser fundamentalmente os maîtres à penser (Sirinelli, 1986; Ory \& Sirinelli, 1992; Déguy, 1993; Trebitsch \& Granjon, 1998).

Como se vê, tais definições, imagens públicas e auto-representações guardam certas linhas gerais. Mas isto não permite pleitear a existência de parâmetros trans-históricos e de validade universal a definir, de uma vez 
por todas, 'quem é' ou 'o que' faz um intelectual. A respeito, os historiadores passaram a perceber que essas divisões conceituais são, elas mesmas, produtos da história, devendo, portanto, ser relativizadas de modo a revelar riquezas, matizes e diferentes dinâmicas.

Seguindo a trilha proposta por Zigmunt Bauman (1987), pode-se tentar designar para o intelectual moderno um conjunto de traços estruturais reunidos sob a fórmula 'poder-conhecimento'. Essa definição, por pretender dar ao pensamento status de ação política, permite, de um lado, que o intelectual seja entendido como um criador e um mediador cultural, ou como um 'homem que pensa' e participa das tensões sociais próprias ao seu tempo; de outro, a problematização de esquematismos rígidos que o qualificam meramente como o crítico (e não como mais um ator) do jogo político, influenciando-o com sua opinião culturalmente autônoma (Ory, 1990; Charle, 1990).

É nesse sentido, ao rejeitar a noção de 'máxima consciência desencarnada', que os historiadores têm pretendido compreender a atuação dos intelectuais, ou melhor, como as idéias informam transformações sociais, criando e transmitindo novos significados entre os homens. ${ }^{4}$ A partir dessas reflexões, a atual problematização da produção intelectual ganhou um enfoque lingüístico (La Capra, 1983; Darnton, 1990). A linguagem, polifônica e polissêmica, tem sido pensada como um meio de compreensão das relações sociais, sobretudo das suas formas de diferenciação e identidade (La Capra, 1983; Burke \& Porter, 1993).

Dessa abordagem, incorporada desde o linguistic turn dos anos 1970, importa reter a compreensão dos 'estilos de falar', ou dos vocabulários, noções, regras, padrões analíticos, conceitos e esquemas explicativos, como performativos (Guilhaumou, 1981, 1998, 2001). Argumentos, enunciados e idéias têm, assim, valor de ação. Em outras palavras, produzir criticamente já significaria intervir na ordem social (Burke, 1995). Deve-se tentar perceber, na verdade, como os intelectuais escrevem contra o seu tempo (La Capra, 1983).

Inverte-se, assim, a tradicional causalidade sociológica contexto/produção de textos. Essa perspectiva inspira-se nas reflexões das relações pluricausais entre 'idéias' e 'sociedade' desenvolvidas por Reinhart Koselleck (1990, 1999b). Para o autor, novas situações históricas combinam-se a novas idéias, assim como, mesmo ainda, novas idéias criam novas situações históricas. Dito de outro modo, textos podem ser entendidos como criadores de contextos. Nesse sentido, as idéias não são abordadas somente 
como discursos, mas como 'atos' - formulam ações políticas e criam instituições.

Segundo Koselleck (1992), mudanças sociais se fazem representar em variações semânticas, ou seja, novas situações históricas produzem novos usos e significados para as palavras, do mesmo modo que novas formulações conceituais e discursivas podem ser entendidas como indícios de transformações na sociedade. Historicamente, a linguagem é autoreflexiva - ela remete aos eventos sociais e concomitantemente a ela mesma. De um lado, refere-se à sociedade, nela interferindo e sendo por ela conformada; de outro, ganha novos significados e categorias diversificando o seu léxico. E assim é transmitida ao historiador na forma de 'representações' nas fontes. Com isso, pode-se chegar às transformações nas idéias, mas também podem-se compreender as mudanças históricas tomadas como objeto. E isto porque a linguagem guarda resquícios dos sentidos formulados no passado. Koselleck (1992) argumenta que uma história da linguagem não é somente uma história das palavras - seus historiadores lidam inevitavelmente com séries de cruzamentos temporais entre idéias e transformações sociais. No seu dizer, uma história da linguagem é também uma história da sociedade por suas interconexões com as variações nos 'modos de dizer' e nos 'modos de pensar'.

Empreender a análise das palavras e dos seus novos usos e significados torna-se, então, um modo de elucidar os fundamentos e as significações das existências sociais. Significa pôr em relevo a intenção dos autores no momento da escrita, assim como salientar as relações das idéias com a ação, priorizando as transformações que os teóricos planejavam imprimir na sociedade (Pocock, 1990). No livro, trata-se de compreender como os cientistas brasileiros das primeiras décadas do século $\mathrm{XX}$, ao informar os traços e os perfis que reconheciam então em si mesmos, estavam escrevendo contra os padrões estabelecidos, idealizando na verdade uma nova identidade e um novo sentido para o seu mundo.

\section{Os Intelectuais e as Polêmicas}

A historiografia dos intelectuais no Brasil se ocupa, desde a década de 1970, do tema das "idéias fora do lugar". A expressão, cunhada pelo crítico literário Roberto Schwarz (1977), consagrou a interpretação da produção intelectual brasileira oitocentista pelo viés da 'importação cultural'. Ostentatória e em descompasso com a 'realidade nacional', não passaria 
de uma cópia de modelos teóricos estrangeiros, não poucas vezes contraditórios entre si ou já suplantados e obsoletos na própria Europa.

Essas classificações evidenciam uma análise de fundo dos intelectuais. Nela, foram qualificados basicamente como 'retóricos', já que meros repetidores de idéias importadas. O seu proverbial 'verbalismo ornamental' não passaria, nessa perspectiva, de um forte indício da ausência de pensamento original. Daí o reemprego recorrente da expressão 'comédia ideológica' (Schwarz, 1977).

A suposta inadequação entre, de um lado, 'ciência original', e, de outro, 'produção intelectual brasileira', tema herdado de vários teóricos das primeiras décadas do século XX, de Sílvio Romero, Manuel Bomfim a Fernando de Azevedo, por exemplo, fortaleceu-se com essa discussão sobre 'as idéias fora do lugar'. Com isso, assumiu a marca de um parecer acadêmico, impondo a baliza dos anos 1930, os da fundação das universidades, como o momento do nascimento da ciência entre os brasileiros, ou como o começo de uma verdadeira 'revolução intelectual' (Azevedo, 1994).

Como já foi mencionado na apresentação do livro, a ênfase destacada que a institucionalização universitária recebeu nos estudos em história intelectual no Brasil consolidou um preconceito interpretativo bastante usual: o de que a 'ciência' precisaria ser um conhecimento autônomo e desinteressado politicamente (Schwartzman, 1979; Miceli, 1979; Martins, 1987; Pécaut, 1990; Schwarcz, 1993; Azevedo, 1994). Não é por outra razão que, nessas análises, além de suplantar os pensadores diletantes, os homens políticos, a onipresença da temática nacional e o mimetismo cultural, as universidades ganharam verdadeiro status de 'causa' do nascimento do pensamento original no Brasil (Vilhena, 1997; Lima, 1999). Não é por outra razão que, o período histórico que antecede a fundação daquela que é considerada, hoje, a universidade mais importante do país a Universidade de São Paulo (USP) - foi definido como 'ideológico' e como 'pré-científico'.

No entanto, é interessante notar que, em termos cronológicos, a primeira universidade criada no Brasil, em setembro de 1920, foi a do Rio de Janeiro. Na historiografia ocupada com o tema, essa data tem pouca importância porque é entendida como a mera agregação de três institutos superiores de formação profissional - o de Direito, o de Medicina e a Escola Politécnica. Não teria significado uma reformulação suficientemente 'revolucionária' dos métodos de pesquisa ou no ensino superior no país, pois carece- 
ria do 'verdadeiro e novo espírito científico', da disciplina ascética, da técnica rigorosa, de objetos limitados e de pesquisas metódicas (Azevedo, 1994).

A rigor, antes mesmo da discussão sobre 'as idéias fora do lugar', alguns autores, por vias diversas, procuraram salientar a riqueza e a importante contribuição intelectual da dita fase 'pré-científica' no Brasil. Entre eles, ganham destaque Guerreiro Ramos e Roque Spencer Maciel de Barros. ${ }^{5} \mathrm{O}$ primeiro, por não atrelar a análise das obras a cronologias temporais ou marcos institucionais (Santos, 1978); o segundo, por realçar os novos temas desenvolvidos nesse movimento intelectual no seu diálogo ativo com as teorias importadas (Barros, 1986). Wanderley Guilherme dos Santos, com especial densidade, também rediscutiu essa interpretação. Segundo ele, tal esquematização, além de epistemologicamente equivocada, por induzir a uma visão estereotipada da intelectualidade, não passaria de um 'simplismo', por ordenar a ciência brasileira em rigoroso atrelamento às suas características institucionais e às conjunturas políticas do país. Muito esquematicamente, como vemos a partir desses autores, a análise criticada obedeceria à seguinte cronologia: oposição à Monarquia, campanha republicana, decepção com a República, engajamento na 'resolução' dos problemas nacionais, fundação das universidades com sua blindagem frente às influências políticas e sociais, e, enfim, nascimento da ciência segundo padrões universais (Santos, 1967).

A reificação da análise institucional incorpora também a célebre oposição entre Rio de Janeiro e São Paulo. De um lado, a suscetibilidade da 'intelectualidade carioca' ao mundo público da política; de outro, a origem privada, burguesa, acadêmica e autônoma dos 'cientistas paulistas'. Como nas palavras de Sérgio Miceli (1989: 93), "o Rio de Janeiro está para a política, assim como São Paulo está para a ciência". Na origem da descompensação entre as distintas vocações das duas cidades, suas funções históricas e seus perfis culturais (Carvalho, 1988).

O Rio de Janeiro, na condição de centro político do país, teria tido a obrigação de se apresentar como a fachada de um Brasil civilizado; o que levava os seus intelectuais, os auto-encarregados dessa epopéia civilizatória, a se converterem em vorazes imitadores da cultura européia, desprezando o Brasil e sua verdadeira 'base social'. Os paulistas, por sua vez, teriam gozado da sua criatividade cultural, já que desembaraçados dos encargos tanto da importação das idéias quanto da exportação da boa imagem do país. 
A consagração desses modelos tendeu a exagerar o pretenso caráter lacunar, periférico e historicamente atrasado das manifestações culturais brasileiras. Acrescente-se que, seguindo as premissas da sociologia do conhecimento, essa bibliografia voltou o seu interesse para a origem nacional das teorias científicas (Santos, 1978). Seu enfoque se concentrou, então, no agrupamento dos intelectuais em ferrenhas correntes de pensamento, tornadas sem sentido fora do seu contexto nacional de criação. ${ }^{6}$ Isto equivale a dizer que a ciência, nessa interpretação, não é percebida como uma forma de conhecimento cujos critérios de avaliação e de atribuição de mérito, códigos, regras, instrumentos, convenções e procedimentos de análise têm historicidade, intensa circulação, releituras, justaposições conceituais e reapropriações. Não é preciso dizer, mais uma vez, que trabalha prioritariamente tanto com a idéia de cópia de conjuntos teóricos estrangeiros retirados das suas matrizes quanto com a proverbial incompetência dos brasileiros em lidar com tantas especulações e doutrinas.

Proponho, assim, como alternativa à relação causal que a matriz institucionalizante parece obrigar - entre a fundação da universidade e a imediata cientificidade dela decorrente -, a investigação mais atenta dos cânones científicos em voga na virada do século. Contesto, com isso, a afirmação de que os descaminhos político-institucionais do país atuavam como um entrave à produção científica nacional, estimulando tão-somente debates parlamentares, controvérsias jurídicas, apartes rocambolescos e retórica política. Privilegio, na verdade, o enfoque na 'construção' do modus operandi da ciência - das suas epistemologias, disciplinas, métodos, aspectos institucionais e objetos, nas suas variedades históricas e em diferentes regimes de validação dos conhecimentos.

O que se pretende salientar, enfim, é que toda essa discussão sobre a 'cópia das idéias estrangeiras' figurou como chave de leitura da historiografia tanto para explicar os supostos atropelos da geração de intelectuais da virada do século XX quanto para justificar o pretenso recurso à retórica, ora como fruto exclusivo da oratória política, ora como um ardil para mascarar a falta de idéias nativas em todo o período. Nos capítulos seguintes, veremos como essa interpretação não passa de um preconceito de época encampado, seguidamente, pela bibliografia que adotou e reproduziu os adjetivos que os postulantes à especialização intelectual então imputaram a essa produção cultural - ecletismo teórico, superficialidades em geral, jactância pessoal, o pasmo pela Europa e verborragia. 
No entanto, como se pretende demonstrar, não estavam a embaraçar-se com palavras pomposas e importadas, mas a pleitear a adoção de um novo modelo de atividade intelectual. No caso vertente, novidades teóricas, sugerindo novos parâmetros para o discurso e para a carreira científica, infiltraram-se de heranças culturais, e, enquanto as primeiras lutavam para se firmar, as segundas insistiam em resistir. É essa a história a ser contada nos próximos capítulos.

\section{Notas}

A expressão é de Lucien Febvre e foi citada por Chartier (1990: 34).

2 Essas observações derivam dos estudos pioneiros de Mayer (1987), que investigou a durabilidade histórica da herança cultural do Antigo Regime e sua fusão com os ditos 'valores burgueses e modernos' na Europa oitocentista. Importante é também o livro de Jacques Le Goff (1957), no qual, por intermédio de um "feliz anacronismo", como nas palavras de Pomian (1998), tratou da constituição dos intelectuais da Idade Média como um novo grupo social, que, oriundo do clero, passou a afirmar progressivamente a sua autonomia nas universidades medievais através do estudo da teologia, da filosofia e das traduções do grego e do árabe para o latim. O "feliz anacronismo" se explicaria por Le Goff ter rompido, com muita originalidade, com a idéia préconcebida, sobretudo na França, de que os intelectuais seriam, então, um fenômeno muito recente. No mais, à época do lançamento do seu livro, em 1957, rigorosamente ninguém naquele país se interessava pelo estudo dos intelectuais, tendo sido Le Goff o primeiro a tomá-los como um objeto específico da reflexão historiográfica - tendência que, segundo Pomian, só se acentuaria na França a partir da década de 1970.

3 Nesse vocábulo de, até então, escassíssimo uso, incluíram-se os peticionários de curtos manifestos que tomaram a imprensa francesa no ano de 1898. Na verdade, protestavam contra a condenação do capitão francês Alfred Dreyfus, acusado de espionagem em favor da Alemanha. Os signatários desses manifestos, Émile Zola, Anatole France, Marcel Proust, André Gide, Charles Péguy, entre outros, pleiteavam pela inocência do capitão, que, no seu entender, tinha sido condenado tão-somente por ser judeu. O sentido da expressão fortaleceu-se, portanto, como o de engajamento numa polêmica pública de modo a impedir o sacrifício da verdade. Sobre o tema há vasta bibliografia (Charle, 1990; Ory \& Sirinelli, 1992; Stoekl, 1992; Prochasson \& Rasmussen, 1996; Prochasson, 1997; Winock, 2000).

4 Deve-se ressaltar que a reflexão sistemática sobre o tema foi estimulada, em primeiro lugar, pela incorporação de alguns conceitos-chave da antropologia - como 'cultura', 'representação coletiva' e a análise da relação dos valores com a ação social - na esteira dos escritos de Émile Durkheim, Marcel Mauss e Max Weber. Em segundo lugar, pela intensificação dos usos da propaganda e dos mass media nas últimas décadas e, finalmente, pelo legado da psicanálise que não pôde mais ser negligenciado no que se refere à eficácia das representações e símbolos nas práticas coletivas. A psicanálise pôs em evidência que a imaginação não é uma 'faculdade humana', nem 
um "poder psicológico autônomo, mas sim uma atividade global do sujeito para organizar o mundo" e ajustá-lo "às suas necessidades e aos seus conflitos" (Baczko, 1985: 307-308).

5 Devo à Nísia Trindade Lima a oportuna indicação dos autores citados.

6 Jacques Roger, importante historiador francês das ciências, qualifica esse tipo de abordagem de "miopia nacionalista", alegando que seus precursores parecem esquecer que a ciência moderna nasceu na Itália católica e não no mundo anglo-saxão protestante. Desse ponto de vista, estariam incluídos no próprio 'difusionismo' ou na pretensa 'cópia' que tendem a sentenciar nos países fora da Europa. Sua crítica se amplia ainda mais ao negar o pressuposto de causalidade entre uma sociedade e a 'sua' ciência nacional como se fosse possível isolá-las num tête-à-tête imaginaire e, a partir desse procedimento, medir o seu grau de originalidade. Completa a argumentação, afirmando que um discurso científico não nasce espontaneamente de uma estrutura social. Ele emergiria, do seu ponto de vista, por intermédio do nascimento de novas idéias e da transformação de tradições de pensamento, e que, inclusive, atravessam séculos e sociedades as mais diversas. Para uma crítica mais completa consultar Roger (1995), Roger \& Louis (1988). Para uma crítica dessa abordagem na historiografia brasileira, ver Alonso (2002). 


\section{A sociedade culta da capital Federal}

Perdendo a fortuna, voltou-se e viu-se, com tão inestimável sabedoria, nas ruas do Rio de Janeiro, sem saber o que fizesse dela

Lima Barreto (apud Santos, 1983)

Ontem

Para a produção dos seus lindos versos líricos, o poeta recolhia-se à miséria da sua mansarda e com a clássica pena de pato e à luz de uma vela de sebo, invocava a musa.

Hoje

A inspiração vem quase... mecanicamente, através do rumor rítmico da máquina de escrever e sob a claridade moderna da luz elétrica. ('Posições intelectuais' , Fon-Fon!, n. 9, jun. 1907)

Bacharelismo, instrução, retórica, polêmicas, discursos, conferências, leituras, réplicas, tréplicas, apologias, contraditas e vasta ilustração... Que assuntos poderiam animar mais a vida mental brasileira em fins do século XIX? Todos os temas reputados como de ordem nacional naquelas décadas de transição do Império à República - a escravidão, a Guerra do Paraguai, a adoção de mão-de-obra imigrante, o regime político, o 'caos' das repúblicas vizinhas, a separação entre o poder espiritual e o temporal, a liberdade de consciência, o ensino, o branqueamento racial e o progresso do país. Matérias que ajudavam a incitar o já então predominante clima de 'efervescência intelectual'. E, no período, a convicção na transformação social pelas difusão e aplicação das idéias tornava oportuna a proposição de caminhos em direção à civilização.

Na verdade, essa ebulição intelectual começou com o processo de consolidação do Estado, logo após a independência de Portugal, e quando os temas nacionais passaram a ser discutidos pelas elites no seu duplo perfil, o político e o letrado (Carvalho, 1981; Guimarães, 1988). Inicialmente, por exemplo, na Academia Imperial de Medicina, onde o ideal de fundação da nação relacionava-se à exuberância do clima e da natureza tropicais (Kury, 1990a; Cabral, 1995). Esses dois elementos foram identificados pelas gerações românticas como 'os melhores do mundo', graças às suas variedade, 
beleza e fertilidade inigualáveis. Pode-se mencionar ainda a Academia Imperial de Belas Artes. Sua produção artística privilegiava a feição de pinturas e esculturas que tematizavam a pujança das paisagens e os motivos indígenas.

A temática nacional também ocupava os membros do Instituto Histórico e Geográfico Brasileiro (IHGB) e suas propostas de leitura e escrita da História do Brasil. O que se visava era à produção de uma visão homogênea do país e à fundamentação histórica do projeto nacional através da construção dos seus mitos e representações. Ao IHGB caberia definir as coordenadas de um projeto historiográfico capaz de garantir aos brasileiros uma identidade única e uma missão no conjunto das nações. Calcada em perfis românticos, a história conferiria sentido ao passado e originalidade ao tempo presente (Guimarães, 1988; Domingues, 1989).

Nessas formulações, a natureza-pátria funcionava como a raiz comum a todos os brasileiros, e a valorização dos produtos nativos operava como um elogio extensivo a todos os habitantes do Império (Kury, 1990a). Nesse sentido, imperativa era a descrição dos elementos locais como traço distintivo e critério de valor. O mérito de uma obra intelectual dependia da sua força representativa (Ventura, 1991).

Note-se a persistência da questão nacional na chamada geração de 1870. Uma constante nesse discurso era a procura da chave da identidade brasileira, visível na análise realizada de certos atributos, como o meio físico, a raça, a cultura e a história. Interessados no desenvolvimento de um pensamento nacional, os letrados pretendiam traduzir o país, e isso passava pela redefinição de suas estruturas fundamentais. Nesse sentido, a nação a construir constituía o foco central das suas reflexões (Mota, 1992; Barbosa, 1974).

Alguns dos nomes mais significativos dessa 'geração', como Sílvio Romero, vieram da chamada Escola de Direito do Recife, onde Taine, Renan, Balzac, Stendhal, Flaubert, os Goncourt, Le Roman Expérimental, de Zola, Daudet, Maupassant e O Primo Basílio, de Eça de Queirós, eram célebres na pregação da aplicação na literatura de métodos então entendidos como 'objetivos'. Essa modificação na maneira de ver e debater os problemas do país foi então chamada por José Veríssimo, outro ilustre componente desse grupo, de o 'modernismo' da cultura brasileira (Miguel-Pereira, 1988). E isso, de acordo com aquele "bando de idéias novas" que sacudiam o país, como na conhecidíssima e repetida frase de Romero - o positivismo, o evolucionismo, o darwinismo, a crítica religiosa, o naturalismo e o cientificismo. 
Uma das características mais marcantes dessa geração eram os seus modelos de 'linguagem contestante', como na feliz expressão de João Alexandre Barbosa, contra os esquemas de pensamento e de interpretação derivados do romantismo. Oposição creditada à adoção do realismo-naturalismo, tornando obrigatório o primado da observação do meio como modo privilegiado de conhecer o país (Barbosa, 1974).

Todos esses foram temas relacionados ao processo de elaboração da consciência nacional no Brasil - além da exaltação do exotismo da paisagem, a fidelidade à realidade local, a valorização das populações indígenas, a demanda pelo progresso do país e a incorporação dos padrões europeus. Nessa formulação, os brasileiros deveriam ser, ao mesmo tempo, nacionais e universais (Candido, 1997).

O caráter marcante dessa geração de 'homens de letras' oitocentistas era uma atuação inclinada a fazer equivaler a criação cultural à mudança social e à interpretação do momento político. À parte suas ocupações oficiais como funcionários públicos, políticos, advogados, professores, militares, engenheiros ou médicos, de onde efetivamente retiravam as condições de sua sobrevivência, os letrados sentiam-se, na época, como os portadores de verdades, vocação, destino e sentimentos superiores aos demais homens, e "sobre o terreno comum do nacionalismo, abraçavam-se as boas intenções" (Candido, 1997). O nacionalismo era, antes de tudo, uma atitude intelectual que redundava em ação civilizatória. ${ }^{1}$

\section{Os Enciclopédicos e a Glória Intelectual}

A inserção do Brasil no Ocidente foi o tema central das manifestações intelectuais brasileiras oitocentistas. A diretriz básica dessa intelectualidade foi a dialética do nacionalismo - a 'substância' da expressão intelectual - e do cosmopolitismo - a sua 'forma' de expressão. Padrão dentro do qual os letrados definiram lentamente a originalidade brasileira, e não a despeito da matriz ocidental européia, mas por causa dela (Candido, 1997).

Pode-se afirmar que essa intelectualidade esteve toda voltada para a construção de uma cultura válida para o país. De um lado, ilustrava e valorizava o Brasil, 'exprimindo', palavra-chave, a chamada realidade local; de outro, levava à Europa a mensagem da existência dos brasileiros, visando à incorporação e à total equivalência com os padrões ocidentais, de onde a indissolubilidade entre a produção intelectual e a reflexão política em todo esse período. ${ }^{2}$ 
Essa produção cultural esteve marcada por uma espécie de função histórica e de compromisso com a vida nacional. Era como se, ao escrever e pensar, os letrados estivessem tomados pelo sentimento de dignidade, distinção e excelência da reflexão intelectual, 'fazendo também um pouco da nação' e contribuindo para o desenvolvimento dos seus padrões de civilidade. Ignorar tal dever patriótico gerava no letrado um pungente sentimento de deslealdade que corrompia não só a consciência, mas a própria obra (Candido, 1997). ${ }^{3}$

A rigor, essa aliança entre criação intelectual, intenção moral, propósito pedagógico, militância política e atuação civilizadora, guarda suas raízes, como já se discutiu no capítulo anterior, na filosofia das Luzes do século XVIII. ${ }^{4}$ Daí o empenho na difusão do saber e a confiança na força transformadora do conhecimento (Vovelle, 1997). Esse movimento ilustrado amoldou-se às idéias políticas dos letrados brasileiros desde as suas primeiras manifestações na Sociedade Literária do Rio de Janeiro nos últimos anos do setecentos. Origem iluminista que continuou vigorando nos meios intelectualizados do século seguinte sob a forma de um saber diversificado que reunia ciência, humanidades e artes. ${ }^{5}$

Nesses termos, tanto melhor era o letrado quanto mais eclético fosse (Cassirer, 1992). Não se poderia conceber como um 'sábio' alguém que cultivasse um só gênero de estudos. Antes o contrário. Percebiam-se, inclusive, como possuidores de uma curiosidade aguda, incansável e interessada tanto em fazer progredir a humanidade quanto em desvelar os mistérios da natureza. E para dar cabo de tão ambicioso intuito só mesmo reunindo séries de conhecimentos em matemática, medicina, cirurgia, história natural, física, química, literatura, mineralogia, topografia, história, política nacional e estrangeira, estatística, comércio, botânica, eloquência, geografia, agricultura, hidrografia, artes, gramática e filosofia. Em todo esse período, o imperativo da compreensão da totalidade do universo e uma 'cultura do desejo de conhecer' se entrecruzaram por completo (Pomian, 1987; Gingras, Keating \& Limoges, 2000).

Em outras palavras, o saber era concebido como um campo unitário onde o pensamento humano poderia, e deveria, passear de ponta a ponta. O sábio pretendia realizar um inventário de toda a realidade sob os seus aspectos naturais, históricos, políticos e sociais (Gusdorf, 1972a; Mandrou, 1973; Gaulin, 1991). A ciência, ou melhor, a filosofia natural, não passava da execução dos princípios da arte, ou seja, de regras, métodos e artifí- 
cios para a observação dos fatos. E como ciência e arte estavam unidas, não havia qualquer tipo de descontinuidade entre, de um lado, o domínio do pensamento e, de outro, o da ação; ambas circulavam e se fecundavam mutuamente por meio das habilidades dos homens (Picon, 1994). Era indissociável da cultura letrada do período a intenção de compreender e modificar a natureza e a sociedade em conjunto e por intermédio da reunião de conhecimentos sobre os climas, os costumes, as raças, a flora e a fauna. ${ }^{6}$ Como se percebe, não se conheciam, então, as múltiplas divisões epistemológicas estabelecidas no pensamento europeu apenas no século XIX. Na verdade, reporta-se a uma outra consciência epistemológica. Refere-se também a uma ética intelectual coerente com as premissas do século filosófico, e a partir das quais alguém, 'havendo encontrado a verdade', tinha a obrigação moral de transmiti-la aos 'menos esclarecidos'. Aristocratismo e sacerdócio eram inseparáveis nessa condição de difusores das Luzes e de praticantes das atividades do espírito na ocasião (Santos, 1992). E exatamente graças a esse 'senso de missão', os letrados percebiam-se como constituintes de um segmento especial da sociedade (Candido, 1967). Sua sensibilidade, aliás, estava fundada no orgulho - por pertencerem a um nível social mais elevado e por se terem beneficiado de uma formação cultural ampla, constante, completa e mais esmerada que a dos demais homens (Elias, 1995).

Assim, desdobrando-se em múltiplos papéis, os intelectuais pugnavam pelas causas mais dignificantes para o país. E uma vez que desconheciam especialidades intelectuais, a vastidão dos espíritos era a sua qualidade mais proeminente. Disposição para conhecer que, inclusive, "não encontra[va] barreira, nem se detém[tinha] perante os mistérios deste mundo sublunar" (Arthur Motta, 'Academia Brasileira de Letras', Revista do Brasil, n. 58, out. 1920, p. 174).

Sob o adjetivo 'intelectual' incluíam-se, como já se sabe, os doutores, cronistas, bacharéis, parlamentares, poetas, publicistas, declamadores, médicos, letristas, escritores, conferencistas, acadêmicos, filólogos, romancistas, artistas, oradores, polemistas, professores, prosadores, polígrafos, sábios ou homens de ciências, conhecedores de várias línguas, líricos, enfim, toda uma gama de "espíritos cultos" que, "visando a largos horizontes", tornavam-se amantes das letras e pensadores ('Um intelectual', Renascença, n. 39, maio 1907, p. 272). Os currículos dos cursos secundários e superiores que freqüentavam, sobretudo o bacharelado em direito, sustentavam a 
sua formação 'enciclopédica'. Eram homens, em geral, muito bem-nascidos, tendo ainda o costume de viajar e de se porem a par do movimento das idéias estrangeiras. Atesta o seu acesso a recursos econômicos a própria posse de diplomas, já que a educação era, então, um bem escassíssimo. ${ }^{7}$

Enciclopédicos e poliglotas eram 'de letras' porque seu 'delicado espírito' fora educado pela literatura; igualmente 'de ciências' porque por elas ilustrados ('Edital', Brasil Acadêmico, n. 1, jun. 1910, p. 1-2). Diziam ter mais do que o hábito, mas o vício da leitura, calculando em 'milhares' os volumes e os gêneros por eles compulsados. E liam tanto não só pelo desejo de tudo conhecer, mas também para amainar a cediça paixão que tinham pelas letras em geral [Barreto - João do Rio, s.d.]. Nessa ocasião, a competência intelectual se media pelo manejo de uma cultura geral.

O público e os instrumentos de difusão dos conhecimentos dos letrados brasileiros, nas últimas décadas do século XIX, resumiam-se basicamente aos púlpitos, às tribunas parlamentares, aos jornais, às comemorações, lições, memórias, conferências e discursos nas academias e eventos literários. Nesses lugares reinava uma 'cultura auditiva', como nas palavras de Luiz Costa Lima, ou uma 'tradição de auditório', tal como foi definida por Antonio Candido. Ou seja, mesmo quando se comunicavam pela forma escrita, os letrados estavam a primar pelos recursos da expressão oral (Candido, 1967). Nos seus textos, assim como nos seus sermões, reinavam a palavra fluente e a melodia verbal, combinando com o senso didático do seu papel de 'orientadores dos caminhos' (Lima, 1981). A atratividade e a comunicabilidade imediata das idéias eram vistas como fundamentais para o desenvolvimento da coletividade. Somem-se as parcas edições de livros, a baixíssima escolarização e o elevado índice de analfabetismo da população brasileira presumido em 84\% em 1890. Por tudo isso, os letrados eram os criadores, os transmissores e os próprios receptores culturais da época, veiculando suas idéias como pregadores, conferencistas, glosadores, professores e recitadores nas serenatas, conferências, saraus e reuniões. Nessa configuração, a linguagem culta e sedutora era a grande marca distintiva do homem de letras, do doutor e do bacharel. Em outras palavras, o 'verbo fácil', ou a retórica, era nada menos que o correlativo lógico, se não mesmo a expressão suprema da inteligência, ou da aprendizagem, da retenção e da fecundação do saber.

Patriotismo, atuação política, aristocratismo, cultivo da ilustração, retórica e 'tradição de auditório' casaram-se, pois, nos meios 
intelectualizados oitocentistas do Rio de Janeiro. E isto, nos círculos mais 'oficiais' como, por exemplo, nas sessões do IHGB, da Academia de Medicina, do Instituto dos Advogados Brasileiros, do Instituto Politécnico do Brasil, do Instituto dos Bacharéis, da Sociedade Propagadora das Belas Artes ou da Sociedade de Geografia, assim como naqueles eventos que pretendiam contribuir para a 'instrução das demais classes da sociedade'. Quanto a esses casos, não se podem deixar de citar as famosas 'Conferências Populares da Glória' ou os 'Cursos Públicos de Ciências Naturais' promovidos pelo Museu Nacional.

Nesses cursos livres de 'ciências', oferecidos na cidade desde a década de 1870 e onde recebiam acolhida quaisquer amantes das 'boas letras', poder-se-iam acompanhar tanto palestras sobre as premissas básicas da ciência do período - mestiçagem, aclimatação, monogenismo, eletricidade, magnetismo, o fonógrafo, o radiógrafo, agricultura, positivismo, materialismo, geração espontânea, matemática, geometria e transformismo - quanto ainda conferências sobre temas gerais, como literatura, teatro, ensino público, história, 'a terra e o universo', 'o espírito do século XIX', epidemias, casamento, mães de família, riqueza intelectual, civilização, 'futuro do Brasil', filosofia, o microscópio na medicina, o paraíso perdido, imigração, higiene, a natureza do Brasil, 'as paixões e suas influências sobre os atos orgânicos', a família e a formação do caráter, febre amarela, a arte veneziana, Bacon, Maquiavel, Padre António Vieira, Ésquilo, Sófocles, Homero, Virgílio, Dante Alighieri, Camões, Goethe e Shakespeare (Fonseca, 1995-1996; Lopes, 1997).

Os temas eram muitos porque 'homens de letras' eram especialmente apreciados por sua "inteligência assimiladora", assim como por serem "generosos e abertos a todas as idéias" [Barreto - João do Rio, s.d.:7]. Passaram, nessa ocasião, a produzir mais sistematicamente alguns escritos para os periódicos, mas continuavam a manter, concomitantemente, outros vínculos profissionais, sobretudo no serviço público (Freyre, 1974, 2000). ${ }^{8}$ Por tudo isso, as suas atividades como engenheiros, parlamentares, médicos, advogados, administradores, pedagogistas, desembargadores, jurisconsultos, professores e militares eram indissociáveis da sua produção intelectual e reflexão sobre o Brasil.

Amantíssimos dos livros, que os esclareciam e os tornavam sábios, respeitados publicamente, por sua memória e conhecimentos, esses letrados apegaram-se à solução de cultivar idéias. Como esses dois valores - o 
aristocrático e o civilizador - eram-lhes inseparáveis, vemo-los a produzir idéias e, não menos importante, a difundi-las ao máximo (Santos, 1985). Nesse contexto, 'instruir' e 'se instruir' tornaram-se mesmo um apostolado. A crença de que o paralelismo entre o 'progresso da instrução' e o 'bemestar de todos' propiciaria o nascimento de um mundo novo foi uma das motivações para o ditame da produção de idéias que tomou a intelectualidade brasileira da segunda metade do século XIX. Não à toa, a formulação de que a humanidade tornava-se, se não em conjunto, mas em grande parte, mais perfeita e mais feliz a cada dia foi a verdadeira e mais forte crença dessa época em todo o Ocidente. Mesmo os incrédulos do período sabiam listar todas as novidades aparecidas nesse tempo de puro otimismo e fé inabalável no futuro, dando conta de que civilização e progresso eram mesmo sinônimos, desfrutados e vivenciados pelos homens através do pleno domínio do vapor, da eletricidade, do calor, do magnetismo, enfim, por intermédio de uma série de novas descobertas que atestavam a orgulhosa superioridade daqueles tempos sobre os antigos (Béguet, 1990).

A reformulação dos espaços, o refinamento dos costumes, a educação dos espíritos, o desenvolvimento da polidez e das qualidades afetivas e intelectuais dos homens, o cultivo das artes e das ciências, a adoção dos apetrechos técnicos, a aquisição de comodidades materiais e o fortalecimento das leis e instituições, garantindo a afabilidade das relações sociais, eram também elementos fundamentais a figurar, nessa ocasião, em qualquer completa definição do modo de vida civilizado (Starobinski, 1989). ${ }^{9}$ Como o significado da palavra designava tanto o desenrolar do processo de apuro dos hábitos e modos de convivência sociais quanto o resultado cumulativo desse 'estado final' da história, só o empenho em 'civilizar' já garantia a participação nesse 'glorioso' destino (Régaldo, 1974; Santos, 1992; Löwy \& Sayre, 1992; Trebitsch \& Granjon, 1998). E, ao passo que se sentiam mais civilizados, os letrados brasileiros percebiam-se mais "dignos co-participantes do pensamento e da atividade geral do mundo" (José Veríssimo. 'A evolução literária do Brasil', Revista Americana, n. 5-6, maio-jun. 1913, p. 281).

Não causa surpresa, portanto, que doutores, bacharéis e 'homens de letras' fossem, então, alvo de grande reverência pública; o que, aliás, só corroborava e estimulava ainda mais as 'benesses' que o epíteto lhes garantia na ocasião: imenso prestígio social, bons casamentos e boas colocações na política, na diplomacia e na administração pública. Os anéis de grau com esmeraldas, rubis, safiras, topázios, granadas ou turquesas, di- 
zia-se à boca pequena, eram aspirações de toda a gente (João do Norte. 'A fidalguia nacional', Revista do Brasil, fev. 1920, p. 180). Tanta glória se pode mesmo aduzir do longo comentário que segue:

Quando o brasileiro enfia o pescoço pela gola, e logo depois, os dois braços pelas mangas da beca doutoral, satisfaz na vida um grande ideal. (...) Ele exulta nesse dia. E, numa alegria enorme, palavrosa, excessiva e absorvente, espeta o dedo num anel abrilhantado, na exibição de uma pedra simbólica; talismã para os empregos públicos, para os cumprimentos de chapéu mais respeitosos, para o casamento mesmo.

Sente-se numa exuberância indescritível, num contentamento inenarrável. A sua vaidade como que lhe aumenta a estatura; adelgaça-lhe a cintura e enche-lhe os ombros, avultando-lhe o tórax.

Abraçando, na forma do estilo, a família e as amizades, o lar e a sociedade, os progenitores, a parentela, a preta velha da casa, e os inúmeros amigos e admiradores, (...) o nosso compatriota recém-formado abraça o mundo inteiro, afirmando perante o universo a sua glória estupenda de estar doutor, de estar outro, diferente por completo do que ainda era vinte e quatro horas antes. (...) O bacharel (...) cobre-se de macio arminho, empelica as mãos, calça veludo, para as sutilezas imprescindíveis, para a diplomacia dos salões, em que se solicitam e se obtém as nomeações mais inesperadas.

(...) Desde o português ao latim, da aritmética ao cálculo, desde a astronomia à sociologia, em toda a seriação das ciências, ele reina como soberano. Supõese que saiba tudo, que de tudo entenda e de tudo fale como um livro aberto. Fica sendo uma espécie de Larousse ambulante, que todos consultam pressurosos e admirativos, confiantes na sua palavra decisiva. (Joaquim Vianna. 'Psicologia do bacharelismo', Almanaque Garnier, 1910, p. 101-103)

Muito ilustrativa dessa venerabilidade, a citação anterior, todavia, deixa entrever um ligeiro deboche que já pode ser tomado como um indício das difusas baixas que os enciclopédicos começaram a sofrer desde as últimas décadas do século XIX. De todo modo, as primeiras e esparsas condenações resumiam-se ao diploma como um passaporte privilegiado, se não único, de ascensão à política e aos cargos públicos, e não (pelo menos não tão sistematicamente) ao 'caráter ornamental' da sua inteligência livresca (Ferreira, 1989; Coelho, 1999). ${ }^{10}$

Acrescente-se a isso que, mesmo com a República, os bacharéis faziam tão boa figura que muitos lhe invejavam o renome. Mas, em pouquíssimos anos, foram tratados e destratados como uns deslocados, pela teimosia em persistir circulando no novo ambiente, à vista de todos, ostentando suas prebendas públicas e seu pretenso talento inato. Os argumentos para tamanha inversão no seu papel social serão discutidos nos itens que seguem. 


\section{A Crítica aos 'Esnobes'}

Com a mudança do regime político e as reformas urbanas iniciadas sob o comando do prefeito Pereira Passos, vê-se iniciada a Belle Époque no Rio de Janeiro. O embelezamento da cidade - com "suas ruas largas, arborizadas, asfaltadas, marginadas de palácios, que tem hotéis lindíssimos, carruagens riquíssimas, onde não há senão elegância e finura" (Fon-Fon!, n. 35, dez. 1907) - ratificava a sensação geral de haverem sepultado de vez os símbolos relacionados à tradição colonial e concentrava todas as expectativas de progresso e modernização que se iam materializando nas novas construções: o Mercado Municipal, o aterro da Praça Quinze, a Praça Mauá, a Avenida do Mangue, o Teatro Municipal, a Biblioteca Nacional, a Escola de Belas Artes e a majestosa Avenida Central (Broca, 1975; Benchimol, 1992; Needell, 1993).

No mais, os preceitos da ciência ditavam as novas regras de saneamento e higiene, diminuindo a incidência da tuberculose, da febre amarela, da peste e da varíola. Pestilências que tão mal afamados deixavam aos olhos da Europa brasileiros e imigrantes, muitos deles interessados em ganhar a vida no espaço que renascia, cosmopolita e próspero. Na interpretação das revistas ilustradas - inéditos suportes textuais que ganhavam a Capital -, a reforma urbana tinha mesmo instituído a civilização entre os oitocentos mil habitantes da cidade quase como num passe de mágica, constituindo, na verdade, sua incontornável precondição (Santos, 2000). Foi exatamente no feitio de "super-civilizados que nos ajeitamos depois que o dr. Passos nos deu as Avenidas" ('Meias e autógrafos', Fon-Fon!, n. 35, 7 dez. 1907). O termo 'regeneração', usualmente empregado para classificar esse período histórico, exprime com particular acuidade o estado de espírito consagrado na cidade renovada (Broca, 1975; Sevcenko, 1995).

A população que circulava na Avenida Central ansiava por modas recentes - estéticas, filosóficas, de lazer, figurinos e prestígio. Todas essas novas vogas ancoravam no porto do Rio em vapores vindos diretamente de Paris, vanguarda, centro e farol da civilização mundial (Starobinski, 1989). Sem falar no deslumbramento com as inovações técnicas que 'encolhiam' e fragmentavam, respectivamente, o 'espaço' e o 'tempo', como os automóveis, bondes elétricos, telegrafia sem fio, telefones, máquinas de escrever, gramofones e os cinematógrafos. Todas sem precedentes na história da humanidade. ${ }^{11}$ 
Foi a imprensa que, exaltando a extrema civilidade dos 'novos tempos', popularizou uma crônica do divertimento ocupada em captar a graciosidade daquele instante no qual o dia-a-dia era só otimismo. Os jornais e as revistas criaram verdadeiras seções especiais nas suas páginas, todas dedicadas a comentar os novos espaços, hábitos, sociabilidades burguesas e tipos da sociedade carioca. Por tudo isso, a atmosfera de modernização foi particularmente estimulante para o recrudescimento da vida intelectual, para a ampliação do público leitor e desenvolvimento das publicações periódicas (Süssekind, 1987; Ventura, 1991; Sevcenko, 1995; Candido, 1997).

A respeito, cabe dizer que o número de revistas na cidade do Rio de Janeiro só fazia crescer naqueles anos, e, com isso, passaram a constituir, juntamente com os jornais, os principais vetores da produção cultural na ocasião, fornecendo, inclusive, as melhores gratificações e posições intelectuais (Miceli, 1977). Registre-se que, como se não bastassem as dificuldades dos editores nacionais, ramo amplamente dominado até os anos 1920 pelos franceses Garnier e Briguiet, a impressão de livros era escassa e sua distribuição mais precária ainda. As oficinas da cidade eram, na verdade, tipografias organizadas para publicar impressos em geral como os próprios jornais e revistas. E o seu aperfeiçoamento tecnológico naqueles primeiros anos do século XX aumentou o número das tiragens dos periódicos, possibilitando-lhes consideráveis inovações gráficas, como o colorido das páginas e a introdução das fotografias. ${ }^{12}$

Mais eficazes no circuito de idéias que os livros e menos transitórias que os jornais cotidianos, nas revistas trama-se o essencial dos roteiros que agitam movimentos intelectuais (Prochasson, 1991). Por sua importância como, concomitantemente, forte veículo de penetração, fonte de informação e rápido trânsito entre o público letrado, a sua imagem mais corrente acabava sendo a de uma obra de vanguarda em constante circulação (Pluet-Despatin, 1992). Pretendiam garantir melhores ganhos materiais e incentivar polêmicas com a criação de novas orientações culturais, debatidas nas suas charges, comentários, colunas, entrevistas, inquéritos, reportagens, opiniões, críticas, editoriais, artigos, ensaios, seções de cartas de leitores e de variedades. Sua explosão numérica só atesta essa enorme disposição intelectual em produzir e semear idéias novas. Nesse caso, dadas as minguadas condições técnicas que emperravam a publicação dos livros, a imprensa periódica tornava-se o vetor mais adequado para atender tamanho 
empenho, sobretudo pela veloz circulação dos seus produtos. As revistas tornaram-se, assim, o mais almejado espaço para a propagação de idéias e para uma dedicação mais sistemática à atividade pensante. Era "inegavelmente, nos tempos modernos, o veículo mais apreciado da divulgação do pensamento, da vida intelectiva do país, por ser o mais popular, o mais generalizador e o mais rápido" ('Apresentação'. Século XX, n. 1, out. 1905, p. 3).

As revistas pulularam na cidade reunindo intelectuais de renome e outros menos conhecidos. Alguns dos letrados que contribuíam com artigos para essas publicações - isso quando não ajudavam mesmo a fundálas apostando no seu bom nome para atrair leitores - já possuíam ligações com importantes instituições do período como a Academia Brasileira de Letras (ABL), o IHGB, a Academia Nacional de Medicina (ANM), a Sociedade de Geografia, a Escola Politécnica e o Museu Nacional (MN), por exemplo. E foi assim que, afora essas redes institucionais, o incremento da imprensa apresentou aos letrados novas possibilidades de expressão, fazendo surgir também outras formas de percepção e de recepção desses textos por parte do público culto (Fonseca, 1941; Broca, 1975; Sodré, 1983; Doyle, 1984; Bahia, 1990). Graças a uma maior circulação e aos novos gêneros, como a reportagem, a entrevista, os inquéritos, a publicidade, as fotografias, charges, caricaturas e crônicas, a imprensa difundiu novas formas de produção intelectual. O próprio ato de escrever, antes um ofício artesanal porque feito à mão, estava cada vez mais mediado pela intervenção das máquinas de escrever muito propagandeadas na cidade na primeira década do século XX. ${ }^{13}$

Mesmo quando enfrentavam dificuldades financeiras pela escassez de anúncios, colaboradores, leitores e assinantes, ou ainda, quando tinham uma circulação breve, contando apenas alguns parcos números, as revistas acabavam contribuindo para uma certa organização do mundo letrado. Pretendiam-se mais rigorosas, estreitando a quantidade de matérias e de temas a figurar nas suas páginas. Tampouco poupavam os presumidos personalismo e ambição financeira dos jornais cariocas, onde, argumentavam, seus editores só prestigiavam amigos e apadrinhados, ou quem mais se dispusesse a pagar por uma publicação ('Intelectuais esquecidos', Braziléa, n. 1, 1917, p. 49; 'O prestígio da imprensa', Careta, n. 6, jun. 1908). Não eram propriamente 'especializadas' na medida em que pretendiam pôr seus leitores ao corrente do movimento intelectual brasileiro, mas já começavam, crescentemente, a se subdividir em seções 
dedicadas a discutir, separadamente, letras, artes, ciências e temas econômicos, políticos, mundanos, femininos e sociais. Divisões de assuntos e de gêneros que começavam a corresponder, naqueles anos, à própria divisão do trabalho intelectual. Nesse sentido, seu espírito de inovação era incontestável: contribuíam para uma especificação das identidades profissionais dos intelectuais, que se iam reunindo progressivamente nas suas seções temáticas, e funcionavam ainda como uma reação aos padrões mais tradicionais de consagração intelectual.

No que se refere a tradições contestadas, é preciso frisar mais uma vez que, em todo esse período, o anel de doutor, já que caminho fácil para os cargos públicos, gozava de tanto prestígio que ostentar sua posse era êxito que superava qualquer riqueza, quer a fundiária dos tempos imperiais, quer a mercantil dos tempos republicanos. ${ }^{14}$ No entanto, nos primeiros anos da República, nasceu uma consciência aguda da distância entre os grupos sociais tradicionais e aqueles oriundos da burguesia citadina (Freyre, 2000). E tal oposição não permitia subterfúgios: ou bem o vínculo progressista aos novos tempos, ou bem a permanência no 'atraso' dos tipos aportuguesados. Não é por outra razão, inclusive, que os cronistas da ocasião passaram a apresentar os bacharéis como irremediavelmente inapropriados para os novos tempos da Capital Federal. E já que identificada às velhas ligações senhoriais e clientelistas, nada parecia mais démodé que a farta exibição dos canudos dos doutores.

Eram também tomados como alvo privilegiado de deboche. As revistas ilustradas, assim como as de ciências e letras traziam caricaturas, seções de entretenimento e crônicas cômicas sobre a vida intelectual na cidade. A predominância do tom humorístico na imprensa periódica da Capital Federal era muito acentuada, sendo diagnosticada, no próprio período, como uma tendência geral entre os intelectuais da época (Afrânio Peixoto. 'Aspectos do humor na literatura nacional', Revista Americana, n. 2, nov. 1916, p. 30).

Estudo sobre a Belle Époque carioca analisou a recorrência da comicidade nessa inteligência, salientando seu assombro com as rápidas e sucessivas mudanças ocorridas no país (Saliba, 1998, 2002). A abolição da escravatura, a inauguração da República, a modernização da capital, e, logo, a discussão sobre a identidade nacional numa sociedade, ao mesmo tempo, cosmopolita e provinciana, moderna e atrasada, liberal e oligárquica, teriam contribuído, em conjunto, para a perplexidade dos 'intelectuais'. De acordo com o autor, o 
humorismo foi a linguagem privilegiada por amenizar-lhes o peso de tamanhas instabilidades sociais. Saliba destaca ainda os procedimentos discursivos mais utilizados nessas produções para criar o efeito cômico desejado - a concisão, a brevidade, a subitaneidade, a trucagem, a reversibilidade de significados, a desfamiliarização, a antítese e o uso dos estereótipos.

Esses últimos procedimentos foram especialmente examinados por Henri Bergson (1978) em importante análise sobre o riso. Na sua teoria do cômico, o autor salientou que os estereótipos, pela incisiva simplificação dos seus temas, mostram-se particularmente ilustrativos dos motivos que pretendem ironizar. Concentram os significados históricos dos assuntos que expõem, exagerando, no entanto, o contraste, a ruptura e a estranheza com os fragmentos do passado que reúnem nos seus flashes descritivos. E mais: rompem com a cronologia, expõem incongruências temporais, trocam objetos de lugar, sobrepõem e invertem diferentes dimensões espaciais. Em outras palavras, e indo ao encontro dessa interpretação, é engraçado e faz rir o desmascaramento da pompa ilegítima do decadente, do fracassado, do inadequado e do hesitante. ${ }^{15}$ Ou retomando a metáfora da ação teatral apresentada no início do capítulo anterior, os estereótipos ironizam aqueles que 'aparentam ser o que não são', ou mesmo aqueles que insistem em 'representar papéis malogrados'. As representações humorísticas do período se concentravam na descompensação entre padrões de comportamento em vias de se estabelecer e os velhos tipos sociais despertando o ceticismo geral. Aliás, nada mais coerente, já que as caricaturas não passam da desproporção das imagens - encolhem o que se presume enorme, engrandecendo, no mesmo movimento, os tipos mais acanhados.

Na época, nenhuma desconformidade era mais gritante que singelos homens pretendentes a sumidades intelectuais. Também nas revistas de 'ciências e letras' do período, como se verá no quarto capítulo, e não só nas revistas humorísticas ilustradas, pode-se verificar uma cada vez mais forte contraposição entre, de um lado, os 'eruditos' ou 'retóricos' - cheios de leituras que poderiam ser desfiladas em qualquer almanaque de curiosidades -; de outro, os estudiosos de "departamentos da inteligência que o público brasileiro ainda não sabe[ria] apreciar" (José Maria Bello. 'Iniciação literária', Revista do Brasil, n. 36, dez. 1918, p. 404).

Para começar a descrição que deles era feita nas revistas, saliente-se a presumida suntuosidade desses 'homens de letras'. Todos com sua expressão facial ponderosa, trajados solenemente em sobrecasaca preta e 
cartola ('Bilhetes à Cora', Fon-Fon!, n. 28, out. 1907). ${ }^{16}$ Sem esquecer o monóculo e o charuto entre os dedos, e sempre ciosos dos modos elegantes de se portar em casas de fora. Habitués das festas mundanas, dos bailes, banquetes e mesas de doces do Palácio Monroe, recitariam versos, longos trechos de prosa e monólogos que decorariam aos montes; além de cantar cançonetas, dançar valsas e o pas de quatre. Saberiam, é claro, francês, e leriam romances em inglês, alemão e espanhol. Teriam lá suas doses de filosofia, direito criminal, sociologia e de economia política. Na estante, Augusto Comte, Platão, Sócrates, Balzac, Zola, La Fontaine, Byron, Shakespeare - afinal, "um pouco de tudo" ('Vendo autores', Careta, n. 8, jul. 1908). Uma vez de posse desses atributos, toda a gente era cumprimentada como 'doutor', contam as revistas. ${ }^{17}$ Expressão que, como a de bacharel, passou a ser cada vez mais confundida na linguagem corrente da cidade com o genérico termo 'homem de letras'. Idéias proliferariam no espaço público como moscas, inúmeras, e por qualquer pretexto "a gente fala[va] a um sábio de alta envergadura" ('Moscas', Fon-Fon!, n. 11, 22 jun. 1907; 'O astrônomo da avenida', Fon-Fon!, n. 8, jun. 1907).

Grandes celebridades e nomes de fama, os doutores e demais homens de letras teriam lançado a moda 'delicadamente galante' de dar autógrafos - assinaturas que, exageram os cronistas das revistas ilustradas, seriam mandadas bordar nas meias pelas finas 'senhoras up-to-date' da sociedade ('A mania dos autógrafos', Renascença, n. 7, set. 1904, p. 58; 'Meias e autógrafos', Fon-Fon!, n. 35, dez. 1907).

Os demais ilustres cavalheiros, de outras ocupações não tão 'elevadas', sonhariam poder gozar da notabilidade dos dilletantti de então, a circular intensamente pelos pontos intelectuais da Capital: desde as "portas ilustradas da Garnier" às mesas da Colombo ('Arte e casaca', Fon-Fon!, n. 28, out. 1907). ${ }^{18}$ Isso sem falar nas demais confeitarias e livrarias, assim como nas sessões do IHGB, da ABL, da Sociedade de Geografia e tantas outras "gloriosas associações" ('O distintivo', Fon-Fon!, n. 37, dez. 1907).

$\mathrm{Na}$ descrição das revistas, as conferências literárias pululariam no Instituto Nacional de Música, no Cassino e no Teatro Municipal, assim como ainda nos salões das grandes damas e dos casais abastados da cidade ('Conferências literárias', Almanaque Garnier, 1907, p. 311). Os salões dos Araújo Vianna, dos Azeredo, dos Sampaio Araújo, de Laurinda Santos Lobo e os saraus promovidos por Coelho Neto, Inglês de Souza, Olavo Bilac, Medeiros e Albuquerque, João do Rio, Alcindo Guanabara, Júlia Lopes 
e Sousa Bandeira seriam muitíssimo prestigiosos ${ }^{19}$ e disputados, integrando a vida mundana da cidade como os banquetes oficiais, a batalha das flores, as recepções, as temporadas teatrais, os pic-nics, os five-o'clock-tea, as praças, os jardins, as lojas de comércio fino, as confeitarias, os bailes, os chás dançantes, os concertos ao ar livre, as regatas, as corridas de automóveis, os clubes noturnos, de jogo e de music-hall, os turfes, o foot-ball e os corsos (Costa, 1938).

Desconhecidos como habitantes 'naturais' da cidade, os letrados freqüentariam esses locais da sociabilidade burguesa por pretenderem ser igualmente adjetivados como 'chiques', 'elegantes', smarts, 'up to date'... Enfim, 'puro Paris!'. No dizer das revistas, o importante era ser visto, estar presente às confraternizações letradas, ainda que, supostamente, muitos dormissem, outros rissem, conversassem ou lessem ('Na conferência do Ferrero', Fon-Fon!, n. 29, out. 1907). ${ }^{20}$ E nesses pontos de encontro, com seus "assuntos gerais e fáceis, leves ou graciosos" ('Conferências literárias', Almanaque Garnier, 1907, p. 311), os ocasionais bailes de encerramento seriam mais valorizados que os ensinamentos intelectuais dos palestrantes ('Bilhetes à Cora', Fon-Fon!, n. 27, out. 1907).

Acrescente-se que, na virada do século XIX, aos bacharéis, sobretudo àqueles de formação jurídica, atribuía-se o especial talento para a oratória erudita, permeada pelas inúmeras e invariáveis citações de autores da Antigüidade Clássica. No relato das revistas, ao pretenderem se passar publicamente por doutores, ou seja, pelos portadores dos "pergaminhos abre-te Sésamo" (Lima Barreto. 'Extravagâncias oficiais', Revista A.B.C., jan. 1920), os homens de letras da ocasião teriam começado a fazer uso desse recurso, assim como de um palavreado, escrito ou falado, rebuscadíssimo, cheio de citações em língua estrangeira e terminologias de escasso uso. Tudo isso, de modo a denotar tanto o valor, quantidade e profundidade dos seus estudos, quanto a sua superioridade como homens lidos, cultos e atualizados com os saberes produzidos nos centros civilizados da Europa. ${ }^{21}$

Segundo as revistas, quanto mais requintados e incompreensíveis, ${ }^{22}$ mais os cavalheiros elegantes da cidade percebiam-se como inteligentes, altivos e excepcionais palestrantes, já que raríssimas exceções, como efetivamente o eram, num país de maioria esmagadora de analfabetos. Quanto mais palavrosos e conhecedores de autores, teorias, línguas e expressões estrangeiras, tanto mais se arrogariam espíritos cultivados, despertando admiração e notabilidade por tantas prerrogativas. 
Idéias, relata Sílvio Romero, tornaram-se uma 'obsessão', um 'delírio' que se alastrou pelo Brasil inteiro, e pelo qual qualquer 'gaiato' pensavase muito notório e útil ao país só ao troçar em qualquer jornal do tempo, e rimando e soletrando "à sombra do jatobá, onça ou cotia, um b com b - a - bá" ('Instrução e educação', Ciências e Letras, n. 3, maio 1913, p. 43). E desse feitio, existiriam de todos os tipos e gostos - sábios e eruditos, literatos e literateiros - até para exportação (Sílvio Romero. 'O Brasil social', Renascença, n. 27, maio 1906, p. 243-244). No mesmo sentido, havia ainda quem lamentasse aquela 'literatura caótica', disseminada num meio tão 'tumultuoso' ('Artigo de fundo', Careta, n. 4, jun. 1908) e onde "em cada rua, há[via], pelo menos, três poetas líricos e dois amadores de charadas" ('Academias', Fon-Fon!, n. 4, maio 1907).

Segundo os cronistas das revistas, apresentava-se publicamente como 'homem de letras' quem se tinha em alta conta como tal ('Arte e casaca', Fon-Fon!, n. 28, out. 1907), e num cenário em que, como já se sabe, produzir intelectualmente era costume de muito bom tom, por demostrar 'igualdade' com o nível civilizado dos países europeus. A mania de escrever seria tão difundida que uns chegaram mesmo a se perguntar, relembrando o período, se por acaso não seria uma verdadeira doença, nascida da vaidade que teria tomado a vida intelectual, e em que uma minoria era louvada e apreciada exageradamente por produzir e semear letras, somente por jactância ('Concursos literários', Revista do Brasil, fev. 1921, p. 181).

Com a imensa proliferação de 'homens inteligentes', continuam as revistas, o mérito se diluiria no excesso: como tantos seriam os homens de letras a escrever suas linhas, pagava-se muito pouco, e aqueles letrados, todos convictos do seu talento literário, reclamavam não poder viver dignamente da pena. O procedimento habitual seria o de receber pelas contribuições esporádicas aceitas nos jornais. E como, naquela quadra, por serem muitas, as idéias seriam vendidas por qualquer preço, pouquíssimos eram aqueles que conseguiam ter colunas fixas na imprensa diária e, portanto, ganhos mensais ('Moscas', Fon-Fon!, n. 11, jun. 1907). ${ }^{23}$

Nesse sentido, "envenenados pelos excessos do perfume das flores da retórica" ('Lousas', Fon-Fon!, n. 10, jun. 1907), os homens de letras, literatos e doutores seriam, no dizer de Antônio Torres, uma "gente muito estranha": pessoas que não conseguiam falar simplesmente, a não ser rebuscando, enfeitando e adornando longos períodos, supostamente a disfarçar a sua inépcia pela pompa "de um verbalismo tão sonoro quanto 
irritante à força de ser vazio" (Antônio Torres. 'A última frase de Bilac', Revista do Brasil, jan. 1919, p. 116).

Em outra ocasião, a retórica foi mesmo 'posta à venda', como se fosse um poderoso fermento culinário, para aumentar, sem grandes esforços, o volume da massa encefálica dos letrados. 'O baking-powder intelectual' serviria para diminuir o peso dos estudos e dar aparência de sabedoria a quem não a tinha. No caso, muitos intelectuais que, tais como bolos e pudins preparados com fermentos, tornavam-se todos bem fofos (Gastão Cruls. 'O baking-powder intelectual', Revista do Brasil, dez. 1926, p. 24). Pois então: tanta intenção de boa aparência e tanto zelo pela nobreza de porte teriam alcançado, no dizer do período, números dramáticos - a começar pela própria reputação dos homens de letras, algo, supunha-se, tornado absolutamente banal e barato de se conseguir. À vista disso, pelo lirismo, pelo cada vez mais popularizado repertório de clichês e "bengalinhas leves e unhas envernizadas" (Ciências e Letras, n. 9, nov. 1915, p. 169), representavam sintomas de crise intelectual, sobretudo porque acusados de remedar idéias vazias, enfeitadas, sem nexo, cabalísticas, grandiosas, apoteóticas e solenes em demasia e que, não obstante, patenteariam como suas.

No entanto, para começar a organizar o debate, é incontornável esclarecer os sentidos da palavra 'retórica', se não mesmo as significações das condenações que a ela dirigiam parte dos intelectuais brasileiros. E é como discurso, ou melhor, como um estruturante do discurso, que a retórica precisa começar a ser entendida. No limite, seu sentido mais antigo e persistente informa que é a 'arte dos discursos', 'arte de bem dizer', 'arte de convencer' e de obter, por intermédio de argumentos lógicos, a adesão do auditório à tese que lhe é proposta (Perelman, 1952, 1977, 1987).

Na Grécia Antiga constituía, nada menos, que a forma política de falar. Os atenienses conduziam os assuntos públicos (justiça, legislação e política) pela fala, pela persuasão; o que tornava a retórica o fundamento da democracia grega, uma vez que permitia a dispensa do uso da força e da violência. Em praça pública, a retórica era o instrumento pelo qual uma comunidade de homens diferentes chegava a um consenso. E ele era importante na medida em que se respeitava cada homem com a sua doxa. Para além da tradução corrente que a tomaria como 'opinião', a doxa era antes a formulação 'daquilo que me parece', ou seja, de como 'o mundo se abre para mim'. Além do discurso que envolvia a persuasão e o convenci- 
mento, a retórica também pressupunha o orgulho e a glória de se mostrar em público, de ser visto e ouvido pelos demais. Nessa época, a identidade entre fala e pensamento constituía o logos (Arendt, 1993).

Ocorre, no entanto, que o julgamento de Sócrates precipitou a primeira condenação, filosófica e política, que a retórica sofreria na sua história (Arendt, 1993). Platão, para demonstrar a injustiça da sentença que levou seu mestre à morte, formulou o seu conceito de verdade como padrão absoluto, e retirou da 'fala' a legitimidade de que gozava como a mais nobre faculdade humana. Discurso monológico, único e independente das diferenças entre os homens, a verdade, na formulação platônica, não persuade ou convence, ela se impõe pela ausência de incoerências. Para Platão, utilizar diferentes argumentos numa mesma formulação, fazer competir opiniões, ou articular diferentes posições numa única sentença tornandoa plural, era inconcebível num discurso postulante à condição de epistème. Toda multiplicidade, no seu dizer, era ilusória, incontrolável e indigna, daí a sua veemente crítica aos sofistas, definidos como aduladores, sedutores, dissimuladores, enganadores, demagogos e falaciosos. Quanto mais não seja, na filosofia platônica, quem se contradiz não é confiável (Arendt, 1993). 'Regularidade da linguagem' e 'verdade' não se separariam mais, daí em diante, na história do pensamento ocidental (Ginzburg, 2002).

Abalada, mas não desimportante, a retórica foi retomada por Aristóteles em famoso tratado em que era definida como a 'arte dos discursos'. Na filosofia aristotélica, os discursos poderiam ser de três tipos: o deliberativo, o epidíctico (ligado à censura ou à aprovação moral) e o judiciário. Seguindo essa filosofia, os exemplos e os argumentos de autoridade, do passado e da tradição, eram o conteúdo mais fundamental da retórica (Ginzburg, 2002). Esse sentido proposto por Aristóteles fincou-se nas suas origens clássicas, passando por Cícero e Quintiliano. Assim, a retórica tornou-se o bene dicere. Em outras palavras, arte romana de persuadir, que, na tradução do latim, mais do que o sentido aparente de 'bem dizer', significava, na verdade, 'mostrar-se bem, bem aparecer em público'. Em suma: impressionar o auditório, ensinando-o, deleitando-o e persuadindo-o. ${ }^{24}$

E persuasão por intermédio de argumentos e estilos que deveriam se adequar tanto à natureza do auditório (seus costumes e padrões de conduta, por exemplo) quanto aos ensinamentos que se pretendia transmitir. Para tanto, poderiam ser demonstrativos, lógicos, laudatórios, deliberativos e judiciais - o importante é que fossem vastos e variados. Como versava, 
em linhas gerais, sobre o útil e o honesto, desfilando bons exemplos de modo a inspirar admiração, emulação e imitação, as próprias qualidades morais do orador não poderiam ser negligenciadas. Aliás, sua bondade, competência, prestígio, respeitabilidade pública, virtudes, benignidade e prudência valiam, no limite, tanto quanto a consistência dos saberes que manejava. Argumento e orador eram indissociáveis nesse tipo de discurso (Belaval, 1988).

A retórica chegou ao Brasil pela força que essa pedagogia tinha em toda a Europa católica, trazida pelos jesuítas que a difundiram largamente em toda a América espanhola e portuguesa. Persistiu, inclusive, por fazer parte do currículo de humanidades do Colégio das Artes e da Universidade de Coimbra, por cujas cadeiras passaram a grande maioria dos membros da elite política e intelectual do Brasil até o século XIX (Carvalho, 1981).

Afora isso, não se pode esquecer que o valor da conversação culta tinha sido confirmado entre os letrados brasileiros oitocentistas dadas as suas raízes no Iluminismo. ${ }^{25} \mathrm{O}$ cultivo do espírito era indispensável aos homens de letras europeus, e tudo isso porque firmava a aliança entre razão, educação e palavra (Belaval, 1988). Sua imagem e sua performance pública estavam ancoradas na 'arte de bem dizer' ou na 'arte da conversação' (France, 1972; Fumaroli, 1994; Chartier, 1997). O letrado era o homem que, na conjunção de talento, polidez, bom gosto e elocução, fazia da palavra um ato teatral em meio a uma sociabilidade que se pressupunha civilizada. Nesse período, o prazer da convivência entre pessoas que se reuniam para apreciar discursos, com intenções morais e pedagógicas, era sumamente apreciado (Sennett, 1999).

Sucede que os melhores locais para expor-se à vista dos outros, exibindo, exercendo e expandindo sua arte e talento eram os salões, os tribunais, os conselhos políticos, as cerimônias e festas para o divertimento da Corte. Em todos eles, o 'bem dizer', ou a arte da exposição, precisava mostrarse revigorado para convencer, educar, aprazer e emocionar. A felicidade da expressão era a 'finalidade' suprema do letrado no seu passeio por vários ramos do saber e sistemas filosóficos sem se ater a nenhum deles (Burke, 2003). Até porque o homem de letras era tanto mais valorizado quanto maior fosse a sua capacidade de organizar no discurso inúmeras referências. Nessa ocasião, o culto das formas de expressão era inseparável da ilustração filosófica. Muito bem vistas e apreciadas como virtude, honra, exercício de responsabilidades, valor estético e moral, e sinal de muito bom gosto no 'teatro dos 
ilustres' da Corte. Por terem sido as mais promissoras herdeiras da eloqüência latina e fiadoras de toda a grandeza de Roma é que os letrados deveriam passar a 'adquirir' as performances, o refinamento e as maneiras européias, sinônimos de uma verdadeira 'arte de viver'. E essa 'arte' não se tratava só de uma linguagem particular, era um tipo de cultura totalmente à parte, ligada ao luxo, ao divertimento, aos bons costumes, ao bom humor, à polidez, à civilização e ao prazer, todos indispensáveis à vida na Corte (Fumaroli, 1994; Elias, 1994, 1995).

Diálogo de alma a alma, visando à saúde dos espíritos com sua 'terapia da palavra', era também pedagogia (Pessanha, 1989). Sem estilo definido e ignorando gêneros do discurso, a retórica só podia ser definida pelo efeito irresistível que causava quando do seu emprego pelo letrado - a admiração pela grandeza do ornamento, por idéias apreciadas como se fossem sabores. Era por intermédio dessa figura de linguagem, o ornamento, que o auditório sentia-se como que transportado, pelos ritmos e sons das palavras, do desconhecido para o conhecido, descobrindo novas perspectivas de saber e de conhecimento sempre imprevistas. Para tanto, sempre se dependia do talento do letrado e da cultura geral de que deveria ser o portador. Nesse período, o culto da beleza da expressão não era um fim em si. Só fazia sentido se atrelado à felicidade de saber e de bem dominar a maior variedade possível de assuntos (Fumaroli, 1994).

E, se já no século XVIII europeu, com a sua preferência pelo moderno e pelo tempo presente e com a sua rejeição da autoridade da tradição, a cultura geral tornou-se sinônimo de erudição e, logo, de um inútil saber antiquário (Furet, 1982; Hartog, 1998; Burke, 2003), até o início do século XIX, a vida intelectual francesa, mais especificamente, ainda esteve largamente dominada por essa 'cultura retórica'. Criadas por amantes do progresso intelectual, a Association des Amis des Lettres et des Arts, a Société des Travaux Littéraires et Artistiques, a Association Littéraire Internationale, a Société des Amis des Lettres, as Sociétés des Arts et des Lettres, a Société de Civilisation, a Alliance Scientifique Universelle, a Société Académique d' Écriture, a Société Libre des Sciences et des Arts e a Académie des Sciences Morales et Politiques promoviam cursos e conferências livres para desenvolver o bom gosto, o aperfeiçoamento humano, o prazer e o amor pelos estudos em geral (Lasteyrie \& Vidier, 1972). E mais: nos cursos superiores oferecidos na época pela prestigiosa École Normale, a tradição retórica seguia firme nos estudos de história, filosofia, latim e grego 
(Sirinelli, 1994). No mesmo século, inclusive, ainda perdurava entre os intelectuais alemães o ideal da Bildung neo-humanista e romântica de Goethe, de Schiller e de Humboldt, e sob o qual se deveriam reunir todas as competências intelectuais dos homens, nelas incluídas as científicas e artísticas. A Bildung implicava, na verdade, o cultivo das qualidades morais, se não mesmo um objetivo de vida. Visava ao apuramento pessoal pela aquisição de vasta cultura pretendente a fazer emergir as riquezas interiores. E nesse caso, os saberes deveriam ser livremente acumulados, por intermédio de estudos superiores, de viagens, de encontros ou de leituras pessoais (Smith, 1988; Charle, 1996). O que vale reter aqui é a persistência da extrema valorização, na Europa de todo esse período, da vastidão dos conhecimentos como um sinal de nobreza, de distinção social e como um prezadíssimo legado a ser transmitido intacto aos herdeiros (Mayer, 1987).

Mas ocorre que, exatamente no oitocentos, deu-se um empobrecimento semântico da palavra 'ornamento', assim como se agigantou a importância da noção de prova cabal para a ciência (Pessanha, 1989). Fortalecia-se a conviç̧ão na cientificidade de formas discursivas que 'minimizam' discussões sobre estilos literários para se concentrar na exposição dos 'fatos'. ${ }^{26}$ Nesse ponto reside toda a radicalização da crítica ao pretenso ilusionismo provocado pelas palavras que, como se sabe, remonta a Platão. De um discurso, belo e eficaz, feito para convencer, educar, socializar e efetivar a comunicação entre os homens, a retórica transformou-se num mero conjunto de tropos de linguagem absolutamente autônomos frente à 'realidade'. Essa interpretação não referencial da retórica só foi levada a cabo no século XIX como bem demonstrou Ginzburg (2002). Nesse período, exatamente, nasceu a premissa de que 'as coisas' têm significações nelas próprias; artifícios de quaisquer tipos servem tão somente para impedir a revelação da verdade (Pessanha, 1989; Sennett, 1999; Ginzburg, 2002).

No que se refere à produção do conhecimento, fortaleceu-se a idéia de que o fundo valia mais do que a forma, ou, mais explicitamente, que raciocínio lógico, ligado à invenção, e elocução gramatical, ligada à memória, deveriam ser contrários inassimiláveis. Para o intelectual moderno, impôs-se a diferença total entre o 'pensar' e o 'escrever', assim como se estabeleceu a distinção entre argumento, de um lado, e autor, de outro. Daí o entendimento do ornamento como redundante, como absolutamente desnecessário, frívolo, inautêntico e esnobe. Nas mais condescendentes hipóteses, era um luxo e uma perda de tempo. Some-se a isso, a separação 
claríssima que se vinha desenvolvendo, desde o século XVIII, entre a oralidade, destinada a uma platéia reduzida, e a escrita, direcionada a um público de estranhos. Não havia, até então, uma divisão nítida entre composição, de um lado, e a enunciação de um discurso de outro (Fumaroli, 1994).

Acrescente-se ainda que os elementos centrais da retórica - eloqüência e multiplicidade de saberes - foram totalmente renegados no século XIX com a especialização intelectual. Todos esses elementos marcam o início de uma rápida transição: de um modelo vertical de circulação do saber entre mestres e discípulos, e cuja linguagem em comum era a retórica, para um modelo horizontal de produção de conhecimento. O saber passou a ser produzido em ć́rculos fechados e seletivos segundo a lógica das especializações disciplinares (Gemelli, 1997).

Naqueles tempos em que Taine era mestre, e mesmo Victor Hugo e Verlaine se punham contra a eloqüência, a retórica e as humanidades foram deixadas para os 'supérfluos' romancistas, poetas, jornalistas, vaudevillistes e demais homens de letras sem profissão (Fumaroli, 1994). Nesse império da ascese da forma, o convívio com os gentilshommes, para engrandecimento e aprendizado, tornou-se absolutamente inútil (Belaval, 1988). E seu declínio se acentuou tanto quanto se fortaleceu o positivismo, sobretudo na França e no Brasil, com suas separações funcionais entre o teórico, o geral, o conjunto, o secundário, a concepção, a especulação e o espiritual, de um lado, e o prático, as partes, o fundamental, os detalhes, a execução, a ação e o temporal, de outro. Reduzida à mera técnica ornamental dos discursos, a retórica passou a ser entendida como recurso estilístico dos bels esprits interessados em falar eloqüentemente sobre todo e qualquer assunto. Não surpreende, portanto, que tenha sido conotada entre os intelectuais brasileiros rigorosamente da mesma forma.

Desse modo, fica claro que, a despeito das condenações, a retórica nada tinha de especificamente portuguesa, religiosa, política ou literária. Aliás, como se vê, estava em descrédito, não só aqui no Brasil, mas em todo o Ocidente graças à ampliação dos domínios do conhecimento científico no século XIX. A especificidade brasileira nesse debate de idéias, na conjunção entre as humanidades clássicas de Coimbra e a pedagogia ilustrada da boa conversação, não é, portanto, a condenação da retórica ou a sua adoção para mascarar a suposta falta de idéias. Mais significativo é o reemprego do termo para desqualificar, num só movimento, a herança colonial, a ausência de critérios meritocráticos para o exercício intelectual 
e o padrão generalista de produção de conhecimentos, encarnado, como já se sabe, nos doutores, bacharéis e homens de letras que, por dominarem vários assuntos e falarem de maneira vistosa, viram-se questionados na sua utilidade, tendo, inclusive, sido acusados de apelar para a malfadada retórica de modo a obscurecer tamanhas falta de presteza e de originalidade.

Que os diplomas dos bacharéis e doutores estavam, então, associados a toda sorte de sinecuras na administração pública e na política não se discute. Saliente-se, no entanto, que o 'diletantismo' de que foram acusados não se explica unicamente pela sua nula profissionalização frente à geração defensora da adoção de critérios impessoais para a capacitação intelectual. Não só isto. Retórica, cultura geral, exibicionismo, superficialidade intelectual, vaidade e diletantismo gravitavam na órbita de um campo semântico relacionado a um padrão intelectual decadente. E insiste-se, estava a ocorrer uma alteração no estatuto da consciência letrada. Por isso, os enciclopédicos pareciam ser, no próprio período, tão insuportavelmente numerosos - em função da associação que se passava a fazer entre estudos, de um lado, e atividade profissional, de outro. Nada, portanto, poderia causar mais espanto pela gratuidade que a exposição pública por deleite e pedagogia, própria aos tempos da retórica, de saberes e autores no plural. Aliás, ao confirmar que aqueles homens recorriam à retórica por exibicionismo intelectual, frivolidades em geral, ou para bajular e distrair o seu público, os historiadores incorporam não só o preconceito da época como atribuem à palavra um sentido contemporâneo.

No século XIX, a retórica tampouco se reduzia à cultura do combate político oral. A alardeada sapiência dos letrados brasileiros era plenamente coerente com o sentido tradicional da palavra que a aproximava das humanidades e da vasta ilustração. Ao dominarem tantos ramos de saber e tantos autores, os homens inteligentes do Brasil estavam sendo fiéis à sua missão nacionalista e civilizatória, mas, sobretudo, estavam agindo rigorosamente conforme a tradição Ancien Régime de conhecer e 'bem dizer'. Nesse sentido, torna-se claro que mantiveram padrões de comportamento (notadamente o verbo fácil associado à inteligência), que deixaram crescentemente de se coadunar com as novas exigências e definições para a própria atividade intelectual.

Incompatíveis com a monologia da ciência, com o espírito positivo e suas evidências empíricas, cânones científicos que então se desenvolviam e se fortaleciam também aqui no Brasil, não poderiam ser maiores as im- 
posturas da retórica com seus tipos sociais enciclopédicos e eloqüentes. E tudo isso só se deu, mais sistematicamente, na virada do século XX, graças ao desajuste entre a persistente venerabilidade da atividade intelectual e o gradual estabelecimento de uma nova consciência epistemológica mais especializada.

Isto posto, acompanharemos daqui em diante a emergência de um novo panorama intelectual, no qual as antigas condições do exercício letrado começaram a declinar, a subsistir, a esmorecer, a conservar-se, a decair... "Também com as lindas avenidas que temos, com os automóveis, não podíamos continuar na velha rotina de insipidez em que vivíamos. Civilizamos a rua, é natural que também nos civilizemos a nós mesmos" ('Bilhetes à Cora', Fon-Fon!, n. 38, dez. 1907).

\section{Notas}

1 Toda essa discussão entronca-se ao surgimento, nos primeiros anos do século $\mathrm{XX}$, de novas interpretações sociais ocupadas em identificar as principais características do que então se convencionou chamar o 'Brasil-real'. Nessas produções intelectuais, o Brasil autêntico, imaculado, mas atrasado, seria o Brasil dos sertões em contraposição ao cosmopolitismo da 'civilização importada' implantada no litoral. Esse modo dicotômico de representar o nacional coincidiu com a emergência histórica de um novo estilo de argumentação intelectual, distinto, como nas palavras de Wanderley Guilherme dos Santos (1970), do 'individualismo metodológico' do Segundo Reinado. Sucede que, rejeitada a filiação a essa abordagem, a fórmula teórica dicotômica se constituiu no foco central do novo padrão de análise em formação, e, já nas duas primeiras décadas do século, no paradigma incontornável para a produção intelectual brasileira (Lima, 1999).

2 A hipótese de Candido (1997) é a de que a cultura brasileira nasceu de uma síntese de tendências universalistas (integradoras e ilustradas) e particularistas (diferenciadoras e românticas). Sua motivação inicial derivaria do desejo de demonstrar que os brasileiros seriam tão capazes quanto os europeus - exemplos a seguir e não modelos a repetir -, no sentido de terem a sua participação assegurada no sistema simbólico ocidental.

3 Candido (1997: 27, v.1) argumenta que o nacionalismo literário, não só no Brasil, foi "fruto de condições históricas - quase imposição nos momentos em que o Estado se forma e adquire fisionomia nos povos antes desprovidos de autonomia ou unidade. Aparece no mundo contemporâneo como elemento de autoconsciência".

4 Sobre a atuação e visão de mundo dos 'iluministas (luso)-brasileiros' e seu pragmatismo/utilitarismo em questões sociais e intelectuais, ver Dias (1968). 
5 Os sábios europeus, inclusive os portugueses depois da Reforma Pombalina de 1759, eram educados, invariavelmente, segundo uma cultura humanista clássica que preenchia todo o seu currículo (Candido, 1967; Carvalho, 1981; Fumaroli, 1988; Roche, 1988; Santos, 1992; Charle, 1996; Fonseca, 1998; Munteal Filho, 1998).

${ }^{6}$ Friedrich von Hayek (1953) destaca que um sentido mais estrito do próprio termo 'ciência' só nasceu no século XIX, quando a palavra passou a ser empregada para designar disciplinas físicas e biológicas. Segundo o autor, um dos primeiros registros desse uso da palavra aparece no New English Dictionary publicado em 1867.

7 Sobre a 'largueza' dos currículos dos cursos de engenharia, medicina e direito que exigiam para a sua conclusão a apresentação de compêndios sobre a literatura estrangeira, pode-se consultar Coelho (1999), Ferreira (1989) e Edler (1999).

8 A imprensa periódica se desenvolvia na cidade desde a década de 1870. Os jornais vinham-se diversificando graças ao aperfeiçoamento tecnológico das tipografias e abandonando o perfil das gazetas do Império com suas poucas páginas, colunas finas e ausência de manchetes e subtítulos (Fleiuss, 1922).

9 Referência incontornável no tema, Norbert Elias (1994) sugere que a qualidade comum a informar a descrição das atividades humanas como 'civilizadas' se expressa numa autoconsciência orgulhosa: o termo resume aquilo em que uma sociedade se julga superior às outras. Além disso, a idéia de civilização corresponde ao itinerário obrigatório de uma transformação do meio humano, de uma renovação da paisagem do lugar onde se vive e com quem se vive. Ela designa tanto o resultado dessa progressão desejada e o movimento mesmo desse processo quanto define o seu sentido de continuidade. Ela não é somente uma visão histórica da sociedade, mas uma interpretação otimista do significado das atividades humanas (Febvre, 1930).

10 Ferreira (1989), no entanto, destaca a crítica de versão técnica, modernizante e reformadora dos politécnicos contra o 'espiritualismo' dos bacharéis de formação jurídica, e não tanto ao 'enciclopedismo' de sua formação.

11 Nas palavras de Elísio de Carvalho (1909: 58): “Toda a vida misteriosa, complexa e vertiginosa da grande cidade (...) passava ante meus olhos com a rapidez das fitas cinematográficas".

12 Quanto a outros editores, podem ser citados ainda os Laemmerts, Francisco Alves, o Jacinto, o Quaresma, os portugueses Lello e Irmãos e a Livraria Chardron (Broca, 1975; Gomes, 1983; Hallewell, 1985).

13 Só para termos uma idéia da 'sensação' que os apetrechos técnicos representavam para os cariocas, vale citar um dos reclames do Fon-Fon! (nov. 1907): "Grande sucesso!!! Uma criança pode manejar com a OLIVER. A mais perfeita máquina de escrever! (...) A nova Oliver é um verdadeiro vendaval na ligeireza, capaz de desenvolver uma soma incrível de trabalho perfeito em dado tempo, com o mínimo gasto de esforço operativo. Responde ao tocar dos dedos como se fosse uma coisa vivente. É uma realidade e não uma experiência!".

14 Ou como no dizer de um dos personagens de Lima Barreto: "Pareceu-me então que aquela sua faculdade de explicar tudo, aquele seu desembaraço de linguagem, a sua capacidade de ler línguas diversas e compreendê-las, constituíam, não só uma razão de ser de felicidade, de abundância e riqueza, mas também um título para o superior respeito dos homens e para a superior consideração de toda a gente. Sabendo, ficáva- 
mos de alguma maneira sagrados e deificados" (Lima Barreto apud Santos, 1983: 368, v. 1).

15 Peter Gay (1995) chega mesmo a desenvolver esse conteúdo 'sádico' do humor reconhecido por Bergson (1978: 152-153), que definiu o riso como "uma espuma com uma base de sal". Ao aparentar alegria, expressa, na verdade, um desejo de corrigir uma incoerência ou mesmo um 'desvio' social. Daí o seu componente sempre cáustico, mordaz, se não mesmo cruel.

16 Sobre os homens 'mais ou menos de letras' fazendo literatura, cultivando as 'flores da retórica' ou opiniões vazias de idéias, e trajando sobrecasaca, cartola e pince-nez pode-se consultar Costa (1938).

17 "E enfim concluiu o doutor: ele era como toda gente elegante, um doutor" ('Conquistadores', Fon-Fon!, nov. 1907).

18 Ou ainda sobre a Livraria Garnier: "Ficar ali de perna trançada, o ombro contra o batente, as duas mãos solidamente apoiadas no castão da bengala, eis a decisiva demonstração de talento" ('A sublime porta', Kosmos, nov. 1908).

19 Brito Broca atesta o seu sucesso listando, inclusive, alguns de seus autores e temas mais famosos: Coelho Neto sobre 'as grandes figuras da Bíblia'; Bilac sobre 'a tristeza dos nossos poetas'; Oscar Lopes com 'a noite e o dia'; Garcia Redondo e 'a mulher'; Carmem Dolores e 'o que é melhor'; Bastos Tigre em 'sem me rir e sem chorar'; e Medeiros e Albuquerque sobre 'o pé e a mão' ou 'casar é bom' (Broca, 1975).

v Olavo Bilac (apud Broca, 1975: 137-138) escreveu na Kosmos que já tinham feito conferências com música, com música e canto, com dança, com projeções de lanterna, com ilustrações. No mais, ironizou: só faltavam, dali em diante, oferecer brindes ou mesmo dinheiro a todos os "curiosos" que se propusessem a assistir às palestras "do princípio ao fim, sem tossir, sem espirrar e sem bocejar".

21 Como no excelente exemplo que segue: "Ipsis verbis, menino, é uma palavra latina que quer dizer verbi gratia" (Revista da Semana, ago. 1900, p. 124).

22 "Para agradar, é preciso que ninguém entenda!", conforme consta do artigo 'O diretor de uma revista' (Almanaque Garnier, ano III, 1905, p. 416).

23 Entre esses 'privilegiados', Olavo Bilac tinha lugar cativo na Gazeta de Notícias e Medeiros e Albuquerque no jornal O País (El Far, 2000: 35-36).

24 Foi contra o argumento de autoridade, tão valorizado no padrão retórico de produção intelectual, que Galileu contrapôs-se. O elencamento de exemplos parecia-lhe por demais suscetível às ingerências das preferências, erros e escolhas humanas, opondo-se, nesse sentido, ao discurso verdadeiro que, por ser certo e totalmente conforme a natureza, dispensaria a defesa argumentativa, tornada inútil e especulativa. Contra-ofensiva que, na verdade, não faria desaparecer os elementos aristotélicos na filosofia natural. Esse desaparecimento só se efetivaria com Newton, e suas regras e leis gerais, e com Locke, Hume e Condillac, abandonando as especulações clássicas e atendo-se à experiência empírica (Gusdorf, 1974; Pomian 1999).

25 Na verdade, com a reforma ilustrada de Pombal no século XVIII e com a adoção do manual, de Luís Antônio Verney, O Verdadeiro Método de Estudar, publicado em 1746, o conteúdo humanista dos estudos foi acentuado em Portugal. Este último, inclusive, criticava os portugueses por ainda estudarem retórica pelos manuais jesuítas, como também ainda por enfatizarem o seu sentido de deleite e não de persuasão por 
intermédio do discurso. E, mesmo com Verney, para ampliar os conhecimentos e a força da palavra persuasiva, só se fizeram confirmar a importância das vastas leituras em línguas, retórica, poética e filosofia racional (Santos, 1992; Almeida, 1995; Carvalho; 1998).

26 Cf. Guilhaumou (1981), Genthilhomme (1984), Peytard (1984), Gardin et al. (1987), Giere (1988), Cassen (1990), Gardin (1991), Lévy-Leblond (1996), Licoppe (1996), Jacobi (1984, 1999), Grenier, Grignon \& Menger (2001) e Sigrist (2001). 


\section{Entreato: os expoentes da cultura literáría}

Nada como o inútil para ser artístico. Daí o desocupado flâneur ter sempre na mente dez mil coisas necessárias, imprescindíveis, que podem

ficar eternamente adiadas.

Paulo Barreto - João do Rio (1997)

$\mathrm{Na}$ primeira década do século XX, prosperaram e se consolidaram os planos de Machado de Assis e de José Veríssimo, entre outros, reunidos em torno da Revista Brasileira para a fundação de uma instituição inteiramente consagrada às letras no país. Nesses anos, a Academia Brasileira de Letras (ABL), a "Torre de Marfim", nas palavras do seu mais importante fundador, tornou-se o nível máximo de consagração e reconhecimento intelectual em todo o Brasil (Ventura, 1991). Planejada para receber 'os artistas da palavra escrita', a Academia, criada em 1897 aos moldes da Academie Française, definiu nos seus estatutos que os seus membros deveriam possuir obra de indiscutível valor literário (El Far, 2000). Não se pleiteava absolutamente que fossem partidários ou simpatizantes de qualquer corrente política ou escola filosófica, e, "limitada e aristocrática por natureza", a agremiação, situada na sede da Revista, na rua do Ouvidor, reunia os seus membros exclusivamente para tomar chá e conversar sobre literatura. As reuniões realizavam-se para defender o talento dos que já tivessem dado suficientes "provas de amor pela palavra escrita" (José Veríssimo. 'A Academia Brasileira: sua razão de ser, seu programa', Renascença, n. 18, ago. 1905, p. 61). Os membros da agremiação literária precisavam ser todos 'homens de letras', ou seja, na sua própria acepção, necessitavam ter adquirido o foro incontestável de escritores por intermédio da imprensa ou de livros. 
A Academia foi criada para que as letras se tornassem uma profissão remunerada e reconhecida aos olhos da elite culta brasileira. Forçosa era, portanto, a consolidação de uma identidade comum a uma camada muito diversificada e ampla de homens de letras, cuja atividade era tida, na própria ocasião, como excessivamente genérica e amorfa.

Como vimos no capítulo anterior, nesses anos, seu único espaço de exercício intelectual minimamente sistemático era a imprensa. E nela, a labuta oferecida aos homens de letras tendia a ser cada vez menos literária no sentido tradicional: no lugar do trabalho completo e culto do letrado, a rapidez das informações do redator; no lugar de discursos, longos textos ou tratados, mais e mais reportagens e entrevistas com frases breves em curtos parágrafos. ${ }^{1}$

Desse modo, a identidade dos homens de letras e os atributos da sua atividade intelectual começaram a ser discutidos porque percebia-se a sua proliferação como 'diária'. Foi contra essa 'vulgarização' da atividade literária que os criadores da Academia Brasileira e seus demais simpatizantes passaram a se opor.

José Veríssimo, por exemplo, além de ter sido um dos fundadores da casa, foi também um dos maiores defensores do tipo ideal do letrado como um artesão, ou como um 'vocacionado para as letras'. Veríssimo se batia vivamente contra a atividade literária feita às pressas ou como "um passatempo de desocupados" (Elísio de Carvalho. 'José Veríssimo', Renascença, n. 33, nov. 1906, p. 179). A literatura deveria ser, nos seus termos, uma ocupação e não um deleite para as horas de lazer. Sua posição, cada vez mais notória, era: nem tão poucos privilegiados a desfrutar de descomunais mercês e prestígio social, nem tantos incapazes a subtrair-lhes as vantagens. $^{2}$

Nesse encaminhamento, parece razoável supor a seguinte proporção: para a crescente padronização da linguagem literária imposta pelos jornais admitindo homens de letras tão polivalentes, mais proeminentes tornaram-se, por seu turno, as preocupações estéticas dos acadêmicos. ${ }^{3}$ Aliás, estavam mesmo ciosos da definição de regras para a escrita literária, da reformulação da ortografia e do uso de uma linguagem mais apropriada ao gênero de discurso que produziam (El Far, 2000). Ao pretender circunscrever o perfil da atividade que realizavam, caracterizaram, no mesmo sentido, os requisitos prévios para os seus praticantes: qualidades de correção moral, de elegância na escrita e de talento a ser abalizado 
segundo os critérios de uma instituição composta pelos seus mais notáveis representantes (José Veríssimo. 'A Academia Brasileira', Renascença, n. 18, ago. 1905, p. 62) - homens de letras, tais como Machado de Assis e Coelho Neto, herdeiros, por sua vez, de José de Alencar, Bernardo Guimarães, Joaquim Manuel de Macedo e Franklin Távora. Resumindo, os acadêmicos supunham que já era tempo de dar lugar à livre expressão do gênio criador (José Veríssimo. 'Machado de Assis', Renascença, n. 23, jan. 1906, p. 3).

\section{Uma Nova Idéia de Literatura}

A emergência da idéia de literatura como expressão da alma, como a arte de escrever e de aprazer, com indispensáveis artifícios de invenção, de ficção e de cuidadosa composição individual, tal como "uma renda nítida e delicada nas mãos da mais paciente bordadeira", " levou a uma redução do amplo e antigo significado da palavra.

De acordo com José Veríssimo, a literatura não passava da "representação fictícia da nossa vida e sociedade", uma "novidade da imaginação", ou a "felicidade e beleza da expressão", e, mesmo ainda, o "culto da forma e da beleza no verso" ${ }^{5}$ E todos esses preceitos deveriam ser tomados como verdadeiros dogmas estéticos. A essa altura, o 'literato' foi passando a ser um criador de vida, um autor de ficção a quem dever-se-iam exigir virtudes de imaginação, de composição de linguagem e de estilo; preocupações exclusivamente artísticas e ciosas da forma escrita. E escrever, nesse caso, não era fazer corresponder pensamentos a palavras, mas chegar, através da imaginação, ao coração dos homens, revelando-lhes os seus sentimentos em comum (José Veríssimo. 'Machado de Assis', Renascença, n. 23, jan. 1906, p. 1-2).

Desdobrando esse argumento, aos 'literatos' se opunham os "supérfluos do mundo das letras", como nas palavras de Veríssimo, os burocratas e servidores do bem público, os homens de ciência, os bacharéis, sem contar ainda os políticos, professores, diplomatas, homens da sociedade e os jornalistas. Todos com as suas respectivas ocupações, mas insistindo em fazer as vezes de poetas e escritores. ${ }^{6}$ E só seriam beneficiados na sua falsa fama de homens de letras pelo caráter açodado daquela "literatura apressada", "literatura sem livros", "literatura de folhetos, sem nenhuma característica que lhe dê[sse] realce ou valor" (José Veríssimo. 'A Academia Brasileira: sua razão de ser, seu programa', Renascença, n. 18, ago. 1905, 
p. 51, 62). E Veríssimo ainda ponderava - a despeito da novidade do, então, recente surgimento dos decadentistas, parnasianos e simbolistas, por exemplo, a grande maioria dos presumidos homens de letras da ocasião nada tinha a dizer. Segundo ele, faltavam-lhes talento, gênio, disposição especial do espírito, e mesmo o preparo intelectual ou um mínimo de familiaridade com o ofício que usurpavam sem exercer dignamente (Elísio de Carvalho. 'José Veríssimo', Renascença, n. 33, nov. 1906, p. 178).

Com todas essas discussões que sugeriam um estreitamento da noção alargada e corrente de literatura como 'conhecimento', a própria expressão 'homem de letras' começou a tornar-se inadequada para, ao menos, denotar o trabalho realizado pelos literatos - escritores que, gradualmente, passaram a ser reconhecidos como os "focos geradores de leves pensamentos", pelo seu talento para produzir poesia, romances, crônicas, contos, ficção, enfim, arte. O que, em outros termos, significava cultuar a livre inspiração, a beleza, as emoções, os sentimentos e a douceur de vivre. A 'literatura', portanto, seria a mais pura liberdade de movimentos, a inspiração engendrando a arte, a imaginação recriando o ideal, a bela e cuidada forma que reveste as idéias. Toda obra literária teria por obrigação ser uma 'jóia' lapidada e atraente (Sud Mennucci. 'Uma nova expressão de arte', Revista do Brasil, n. 37, jan. 1919, p. 3-7).

Sucede que essa tendência literária acabou culminando na preocupação estética da fase chamada por Lúcia Miguel-Pereira de "sorriso da sociedade", tal como a definira originalmente Afrânio Peixoto. E longe do perfil de "frívolos e deslumbrados" que a historiografia insiste em lhes imputar, esses homens de letras, cada vez mais "puros literatos", como passaram progressivamente a se autodesignar, ${ }^{7}$ estavam, na verdade, a assumir que produziam ficção, que se deixavam conduzir pela imaginação e que o seu ofício era fundamentalmente recreativo, de 'correção' e de 'idealização' da realidade, assim como de deleite e de prazer na criação artística (Sud Mennucci. 'Uma nova expressão de arte', Revista do Brasil, n. 37, jan. 1919, p. 6). ${ }^{8}$ Nas palavras do próprio Peixoto (apud Miguel-Pereira, 1988: 248), em 1940,

a literatura é como o sorriso da sociedade. Quando ela é feliz, a sociedade, o espírito se lhe compraz nas artes e, na arte literária, com ficção e com poesia, as mais graciosas expressões da imaginação. Se há apreensão ou sofrimento o espírito se concentra, grave, preocupado, e, então, histórias, ensaios morais e científicos, sociológicos e políticos são-lhe a preferência imposta pela utilidade imediata. 
E essas preocupações estéticas acabaram arrematando a ABL e parte de seus membros. Parecia-lhes claro de que deveriam representar, sobretudo, a beleza; único tema de inspiração para 'puros literatos'. Nada mais leal, diga-se de passagem, ao legado e aos preceitos artísticos dos principais fundadores da agremiação.

É claro que todo esse esforço não impediu a eleição de letrados de outras formações intelectuais como o próprio Afrânio Peixoto. Toda essa identidade profissional comum que lutavam para forjar e firmar acabou sendo posta duramente à prova com a entrada na $\mathrm{ABL}$ de notáveis sem produção que caracterizasse rigorosamente o fazer literário - poesias, crônicas, romances ou prosa. Mesmo alguns de seus membros, grandes celebridades nacionais do período, não se sentiam plenamente à vontade na casa, alegando, tal como o fizera Rui Barbosa, não serem literatos no sentido rigoroso do termo. ${ }^{9}$

A eleição de Oswaldo Cruz em 1912, por exemplo, desencadeou um grande debate, na imprensa e na própria agremiação, sobre os verdadeiros significados das noções 'homem de letras' e 'literato', e de quais seriam os seus requisitos e atributos. A criação da Sociedade Brasileira dos Homens de Letras em 1914, com vistas a transformar a carreira literária numa profissão que exigisse formação prévia em cursos, congressos e conferências, só corrobora a amplitude de todas essas discussões no meio letrado do período (Broca, 1975). E não eram poucas. Essas mesmas insinuações, sátiras e brigas já deixavam transparecer, exatamente, uma maior especificidade da idéia de literatura.

Como criação artística, a escrita literária deveria obrigatoriamente inventar, criar novas cenas, salientando as "feições diversas e múltiplas de nossa gente", principalmente da sua sociedade mais 'civilizada', ou seja, a que habitava o Rio de Janeiro, contando e enfeitando histórias sobre os seus salões, sobre as suas ruas calçadas, sobre as suas novas fachadas, as roupas dos janotas, enfim, sobre a face mais cosmopolita do Brasil (Elísio de Carvalho. 'José Veríssimo', Renascença, n. 33, nov. 1906, p. 179). ${ }^{10} \mathrm{Na}$ sua produção, mais conhecida como 'beletrista' pela amenidade dos seus temas, prevaleceu a exaltação do espírito de civilidade da cidade, no dizer do período, finalmente liberta do "seu desagradável aspecto colonial, de suas casas sem arquitetura, beiradas de telhados despejando a água da chuva sobre umas ruas tortuosas, estreitas e mal calçadas" (João de Barros. 'Crônica', Renascença, n. 2, abr. 1904, p. 41). Ao assumirem o cunho de 
exaltação da modernidade, tal como no célebre slogan "o Rio civiliza-se", da coluna mundana O Binóculo, de Figueiredo Pimentel, os literatos persistiam no intuito de se mostrarem civilizados aos olhos estrangeiros.

A sociedade brasileira, na verdade a carioca, à semelhança da parisiense, também seria, do ponto de vista desses literatos, policiada, culta, cidadã e perfeitamente digna de definir o que de mais belo eram e possuíam (José Veríssimo. 'Machado de Assis', Renascença, n. 23, jan. 1906, p. 3). A ordem, a beleza e o bom gosto que reinariam na cidade seriam, na sua definição, a mais primorosa matéria-prima para o entusiasmo poético florescer e "em imprevistas combinações de nuvens e de cores, formar quadros extraordinários, surpreendentes", e, acima de tudo, únicos, originais (Elísio de Carvalho. 'José Veríssimo', Renascença, n. 33, nov. 1906, p. 179). ${ }^{11}$

A sua profissionalização como literatos pode ser mesmo relacionada à própria mudança na circulação dos bens culturais, então destinados a um público urbano emergente. Sugestivas são também as redefinições tanto das noções de autoria, de obra e propriedade intelectual quanto as variações na recepção das idéias, até então relacionadas à oralidade (Ventura, 1991). E naquela configuração, como já se sabe, o verbo fácil era ainda um indício de inteligência. Mas, com o estabelecimento de uma produção mais sistemática voltada para os jornais, deu-se o início da discussão sobre a fixação de normas e regras para a escrita, que na imprensa deveria ser mais 'comedida' e ágil. Os jornais contribuíram, assim, com novos elementos, para a crise da cultura retórica dos bacharéis e demais 'espíritos instruídos'.

De fato, os literatos, ao intentarem fazer frente ao crescente privilégio público do jornalismo, começaram, no mesmo movimento, a discutir os fundamentos do seu vocabulário, a pertinência do seu ofício e os gêneros mais apropriados à redação de textos ficcionais. Pretendia-se o total afastamento estilístico da padronização dos jornais, e sua ênfase em notícias. É importante observar também que toda essa defesa da liberdade da forma literária por parte de alguns acadêmicos, como José Veríssimo e João do Rio, por exemplo, não os opunha unicamente aos publicistas e jornalistas. Grande parte da reação dessa literatura que se profissionalizava deu-se contra o realismo-naturalismo - corrente intelectual vista por esses literatos como "uma horrível vulgaridade", se não mesmo como uma "verdadeira depravação estética" (Elísio de Carvalho. 'José Veríssimo', Renascença, n. 33, nov. 1906, p. 179). ${ }^{12}$ 


\section{As Tensas Relações entre a Literatura e a Retórica}

O naturalismo se expandiu nos meios letrados brasileiros a partir da Escola de Direito do Recife pelos idos de 1870 (Miguel-Pereira, 1988). E com a sua proeminência, a aliança entre 'letras' e 'saber científico', própria à configuração mental enciclopédica, começou a apresentar os seus primeiros sinais de 'crise'.

A geração naturalista recusava, de modo contumaz, o que chamava de 'o engano do romantismo'. Segundo os naturalistas, a literatura romântica consistiria na simples manifestação de um ponto de vista, de um ângulo essencialmente pessoal. O que se passava a realçar era a atitude de objetividade na descrição da vida social observada e o comprometimento da atividade literária com o desenvolvimento do país (Martins, 1946; Coutinho, 1969; Costa, 1967, 1989; Leite, 1976; Lima, 1981; Candido, 1988; Mota, 1992). ${ }^{13}$

O movimento literário engendrado pela geração de 1870 pretendia significar uma 'virada anti-romântica', segundo a qual os chamados 'valores artísticos' não deveriam sequer ser considerados (Ventura, 1991; Picchio, 1997). ${ }^{14}$ Para essa corrente intelectual, a experiência literária deveria ser indissociável da análise realista. Com o realismo, a literatura, na verdade, renegou 'a arte de bem dizer', que, no passado, inclusive, tinha sido a sua própria razão de ser, e essa abjuração manifestou-se quando se pretendeu associar linguagem literária à transparência da realidade observada. Em outras palavras, 'retórica' e 'literatura' se afastaram nesse período naturalista.

Entre o romantismo no século XIX e o modernismo no século XX, houve um esforço pela autocaracterização da literatura, e seu ápice foi a oposição entre os escritores de estilo faustoso e aqueles que primavam pelo lado instrumental das suas obras. ${ }^{15}$ Antagonismo este que fez nascer entre os literatos do novecentos a necessidade de defender preceitos artísticos tanto contra o jornalismo e contra o uso da terminologia científica consagrada pelo naturalismo quanto ainda contra o partidarismo em questões políticas e sociais, motivação alçada ao máximo em 1902 com o lançamento de Os Sertões, de Euclides da Cunha, e Canaã, de Graça Aranha.

No dizer de Veríssimo, por exemplo, aquela literatura de Cunha e Aranha era excessivamente monotemática. Ao exigir o estudo do sertão ou do 'verdadeiro Brasil', atinha-se por demais "às regras fixas, às fórmulas apodícticas e aos rigores dos interesses sociais" (José Veríssimo. 'Machado de Assis'. Renascença, n. 23, jan. 1906, p. 3). E com isso, beneficiava os 
'charlatães' que esconderiam, por trás do pleito fácil e do calor da hora, a sua ausência de idéias e de talento para exercer a profissão literária. No seu entender, a literatura como arte deveria ser absolutamente livre, só exigindo do artista talento e sinceridade. Sua missão suprema era levar às almas emoções superiores. Para tanto, o artista deveria ser totalmente espontâneo, capaz de escolher seus temas sem estar submisso a qualquer tipo de ingerência externa. E tudo isso porque se moveria numa esfera totalmente autônoma (e quase sagrada) de produção de pensamentos - a arte.

Como se vê, a corrente literária classificada usualmente como frívola pretendia, tão-somente, fazer da literatura prosa de fiç̧ão. Queria, tãosomente, fazer da literatura uma arte. E, diga-se logo, não se faz menção a uma simples moda literária, mas a uma efetiva mudança no gosto dessa elite letrada que pleiteava a especificação da literatura como uma arte desinteressada. Enquanto isso, mas no mesmo movimento, passavam a associar, cada vez mais, os sisudos temas sociais ao universo da ciência.

O que se quer salientar é que tanto a crítica do realismo-naturalismo ao romantismo quanto a recusa do realismo-naturalismo pela corrente literária prosa de ficção foram, na verdade, os primeiros sinais do afastamento entre os discursos literário e científico. Nesse processo, destacase, sobretudo, o espanto manifestado quando da preconização em se observar de perto o que se procura modificar e aperfeiçoar, rejeitando o sentido romântico de selecionar da realidade toda a vulgaridade e feiúra; movimentos indissociáveis da reformulação do próprio conceito de literatura. ${ }^{16}$ E toda essa discussão levou a uma redefinição mais estrita da palavra, cujo conteúdo forte passou a ser o de 'arte de ficção'. E arte com o uso de muitos adjetivos, hipérboles, vocativos e sinônimos. Recurso legitimado também pelo fato de estarem vivendo um período de transição, quando da expressão oral tinham passado aos domínios da expressão escrita [Paulo Barreto - João do Rio. 'Raimundo Correia', s.d.: 319].

Na verdade, os literatos estariam tão-somente pelejando para se familiarizar com a palavra impressa. E tantos custos porque o discurso oral, seu recurso preferido, seria, além de mais apropriado para transmitir a beleza, uma verdadeira composição musical com palavras cheias de vida, livres, "soltas de todas as cadeias, capazes de por si só definir, pintar e colorir" o mundo. Constituiriam, na verdade, a própria encarnação da sensibilidade humana. De outro modo, à vista da oralidade, a expressão escrita seria morta, passível de prisão e controle [Paulo Barreto - João do Rio. 'Coelho Neto', s.d.: 54]. 
Por conta disso, seguiam justificando o emprego de tantos 'guisos' naquela literatura. O emprego de adornos lingüísticos não passava do desejo de fazer coincidir palavras com 'idéias onomatopaicas', vibrantes, pulsantes e que, só assim, pela sonoridade, poderiam comunicar sentimentos [Paulo Barreto - João do Rio. 'Coelho Neto', s.d.: 54].

Com isto, aparentemente 'voltamos' ao mais forte signo do padrão de produção intelectual dos bons e velhos homens de letras - a sua linguagem 'empolada'. Mas só aparentemente. Ao ser conotada como a 'arte de escrever e aprazer', a literatura beletrista efetivamente ainda foi passível, inúmeras vezes, e já o veremos, de confusão com a retórica. Aliás, as antigas associações sinonímicas entre 'retórica' e 'humanidades' de um lado, e 'humanidades' e 'literatura' como 'conhecimento', de outro, eram, como se já discutiu, muito fortes. Não causa espanto, portanto, que tão sólidos significados não tenham sido apagados, assim de uma hora para outra, nem da semântica, tampouco da história do uso da palavra. Acrescente-se a isso, a censura naturalista ao romantismo, então definido como o 'exagero da imaginação' e a 'pieguice da linguagem'. Nessa configuração, retórica, literatura romântica e literatura beletrista pareciam fazer parte de uma mesma cadeia ininterrupta e indistinta de faladores e escritores aparatosos e exagerados.

A bem da verdade, a ABL e sua 'estética sorriso da sociedade' robusteceram mesmo a notoriedade pública dos homens de letras de palavreado vistoso, contribuindo ainda mais para o largo alcance das suas atribuições. O seu esplendor público foi realçado pela criação e fortalecimento da casa, essa instância de consagração intelectual que, no limite, só reforçava a sua imagem de fiadores da civilização entre os brasileiros, posto que, como consta dos seus estatutos, eram os maiores expoentes da cultura nacional. No entanto, pretendentes a definir mais estritamente o trabalho literário como expressão artística, a ABL e sua 'estética' foram duas peças fundamentais para o definitivo ocaso do padrão generalista de cultivo da inteligência, cooperando para o processo de especialização intelectual que começava a se delinear naqueles anos. E, ainda que tenha sido frustrada admitindo membros tão polivalentes, a ABL precipitou uma percepção da literatura como uma atividade especificamente artística. E tudo isto, sem a menor pretensão enciclopédica. 


\section{Notas}

1 Coelho Neto no seu romance $A$ Conquista, de 1899, expressa através de um dos seus personagens a indignação de um literato ao ser confundido com um jornalista: “(...) Em verdade nada temos de jornalistas. (...) fazemos romances e contos" (apud Machado Neto, 1973: 80).

2 É conhecida a recusa de Veríssimo em continuar na própria Academia após a eleição, em 1911, do engenheiro Lauro Müller, ministro de Transportes e Obras Públicas do governo Rodrigues Alves. Definindo a literatura como a "arte da palavra" e como as "boas e belas letras", renunciou ao cargo de secretário da ABL. Sobre a sua especificação para a atividade literária, ver Veríssimo (1907: 3-4). Sobre o autor, ver Barbosa (1974) e Ventura (1991).

3 Paulo Barreto [s.d.], mais conhecido como João do Rio, no seu livro O Momento Literário apresenta uma enquete feita entre os literatos sobre o papel do jornalismo na chamada 'arte literária'. Quase todos foram unânimes em afirmar o desserviço prestado pela falta de apuro, pela pressa, pelo empobrecimento da escrita nos jornais da cidade do Rio de Janeiro.

4 Palavras de João Luso (apud Broca, 1975: 221-222).

5 José Veríssimo, exatamente, já começava a chamar de "filósofos" todos os pleiteadores a espíritos enciclopédicos. E mesmo para ele, a pretensão à gerência de uma gama tão variada de pensamentos de todos os tipos causava estranheza. Sobre Farias Brito, "filósofo", declarou: "Confesso que sempre me pareceu singular e esquisito o caso deste homem" (apud Costa, 1967: 371).

6 Argumento rigorosamente semelhante foi apresentado por Olavo Bilac em discurso no Palace Teatro em 1904, ocasião em que foi aclamado 'O Príncipe dos Poetas Brasileiros'. Sobre o discurso, ver Machado Neto (1973: 127).

7 Como por exemplo, Medeiros e Albuquerque ('Paulo Barreto no tempo de Wenceslau', Revista do Brasil, n. 18, jun. 1917, p. 20); Amadeu Amaral ('Em torno de Machado de Assis', Revista do Brasil, n. 27, abr. 1918, p. 357) e Miguel Mello ('José Veríssimo', Revista do Brasil, n. 27, abr. 1918, p. 409).

8 Na verdade, pode-se argumentar que o próprio Machado de Assis já defendia a definição da literatura como evasão e recriação da realidade. Rejeitando o chamado 'imperativo nacionalista' defendido por Sílvio Romero para a produção literária, fazia equivaler 'nacionalismo' a 'provincianismo'. Machado de Assis dizia ainda que sua inspiração era nada menos que o 'homem universal' (Lima, 1986; Velloso, 1988).

9 Essa afirmação de Rui Barbosa foi, inclusive, registrada nas atas das reuniões da Academia em 8 de maio de 1919 (El Far, 2000: 91). Sílvio Romero expressou descontentamento semelhante: "Conheci, sem esforço e para meu mal, que, se não sou ao pé da letra um cientista, não me cabe também a denominação de literato, no sentido restritíssimo que este qualificativo tem entre nós" [Paulo Barreto, s.d.: 36].

10 Esse molde 'arte da palavra', de Peixoto e João do Rio, entre outros, não foi incorporado por todos os letrados do período, é certo. Registre-se, pois exemplo maior não há, que o clássico livro de Euclides da Cunha, lançado em 1902, foi recebido no meio intelectual do período como a fonte mais genuína de exposição de um ambiente pouco conhecido e, ainda, como a origem e matriz da divisão de dois Brasis: o do litoral e o 
dos sertões. A dicotomia 'país real' (o dos sertões) e 'país legal' (o do litoral) redundou na representação da inconsistência do trabalho intelectual levado a cabo pela estética 'sorriso da sociedade', pretenso fruto da proeminência das idéias estrangeiras importadas e do desdém pelos 'verdadeiros' problemas nacionais. E a vertente intelectual oriunda do naturalismo, nas suas aproximações entre literatura, ciência e temas sociais, está na origem do processo de constituição e institucionalização das ciências sociais no Brasil (Queiroz, 1979; Vilhena, 1997; Lima, 1999).

11 Sobre a produção literária daquelas décadas versando sobre a cidade, a beleza, a liberdade da imaginação e as benesses modernas, podem-se citar: Coelho Neto. Rapsódias. Rio de Janeiro: Garnier, 1911; Coelho Neto. Jardim das Oliveiras. Porto: Chardron, s. d.; Coelho Neto. A Conquista. 3.ed. Porto: Chardron, 1921; Coelho Neto. Livro de Prata. São Paulo: Liberdade, 1928; Coelho Neto. Vida Mundana. 2. ed. Porto: Chardron, 1924; Coelho Neto. A Capital Federal. 5. ed. Porto: Chardron, 1924; Sud Menucci. Alma Contemporânea: ensaios de estética. 2.ed. São Paulo: Cultura Brasileira, s.d.; Paulo Barreto (João do Rio). A Alma Encantadora das Ruas. Rio de Janeiro/Paris: Garnier, 1910; Paulo Barreto (João do Rio). Cinematógrafo. Porto: Chardron, 1909; Benjamin Costallat. Mademoiselle Cinéma. Rio de Janeiro: Costallat \& Micollis, 1921; Benjamin Costallat. Fitas... Rio de Janeiro: Costallat \& Micollis, 1924; Gonzaga Duque. Graves e Frívolos: por assuntos de arte. Lisboa: Livraria Clássica, 1910; Álvaro Moreira. Boneca Vestida de Arlequim. Rio de Janeiro: Pimenta de Mello, 1927; Raul Pederneiras. Cenas da Vida Carioca. Rio de Janeiro: Editora Jornal do Brasil, 1924; Raul Pederneiras. A Máscara do Riso. Rio de Janeiro: Oficinas Gráficas do Jornal do Brasil, 1917; Bastos Tigre. Arlequim. Rio de Janeiro: Tip. Fluminense, 1922; Bastos Tigre. Fonte da Carioca. Rio de Janeiro: Livraria Leite Ribeiro, 1922; Afrânio Peixoto. A Esfinge. Rio de Janeiro: Francisco Alves, 1911.

12 Na oposição ao realismo, os literatos julgavam se aproximar dos artistas europeus que, na segunda metade do século XIX, preconizaram o ideal da 'arte pela arte'. E nessa moderna concepção devem-se ressaltar a premissa da liberdade do artista frente às ingerências da política e das necessidades do cotidiano, e a sua definição estrita - a arte deveria ser feita pour plaire au goût. Assim, rejeitando tanto o primado da reprodução da realidade na linguagem literária quanto o partidarismo político, os literatos brasileiros remetiam-se ao ideal da beauté, de Baudelaire, à "perfeição do estilo", preconizada por Flaubert, os Goncourt, Anatole France e Mallarmé, assim como ainda ao tema da absoluta inutilidade da arte defendida por Oscar Wilde. Quanto a este último, por exemplo, Paulo Barreto (João do Rio) publicou todo um elogio da sua concepção estética resumida na fórmula: "A revelação final é que a mentira, isto é a narrativa das belas coisas falsas, constitui o fim da arte” ('O Breviário do Artificialismo', Renascença, n. 13, mar. 1905, p. 137-139). Quanto aos artistas europeus, versando sobre a antinomia entre arte e utilidade social, podem-se consultar também Febvre (1936), Cassagne (1959), Benda (1975), Kempf (1977), Karl (1988), Rollemberg (2000), Beaumarchais, Couty e Rey (1994) e Christin (2003).

13 Essa premissa, no entanto, não os opunha (ao contrário do que pensavam) aos românticos. Como bem argumenta Lima (1999), com o naturalismo há mesmo uma superposição da descrição realista com a valorização da literatura como a construtora da nacionalidade. 
${ }^{14}$ A propósito, vale citar as célebres polêmica e condenação feitas por Sílvio Romero a Machado de Assis e a José Veríssimo, cujas obras pecariam, segundo ele, pela ausência de contornos políticos e pela dubiedade da suas posições como literatos e brasileiros (Barbosa, 1974; Ventura, 1991).

15 Os chamados 'literatos boêmios', os outsiders de então, também tiveram atuação preponderante na valorização dos produtos literários, participando dos grupos que fundaram as revistas ilustradas, e isso por força das reclamações que lançavam às permissivas admissões na ABL. Para tanto, basta lembrar o mais ácido e mordaz dentre todos eles: Afonso Henriques de Lima Barreto (Broca, 1991; Sevcenko, 1995; Velloso, 1996; Gomes, 1999).

16 Os parnasianos e os simbolistas foram os mais chocados com a uniformização da linguagem literária e com a objetividade requeridas pelo naturalismo. Não à toa, foram os que mais apelaram para a ornamentação narrativa do discurso, assim como foram os que mais defenderam a idéia de 'artesanato literário' (Candido, 1997). Cabe acrescentar que o naturalismo engendrou uma discussão sobre a especificidade da atividade literária também na França. Ao pretender aplicar na literatura os métodos das ciências naturais, Zola acabou por precipitar a mais estrita definição dos preceitos artísticos na escrita literária (Charle, 1979; Chevrel, 1982). Mesmo na França, inclusive, com o sucesso do naturalismo nas suas associações com o então triunfante discurso científico, também atribuíram-se frivolidade e esnobismo à arte, acusada ainda de ser "moralmente inautêntica". Cf. Sennett (1999). 


\title{
A Generalidade em Críse
}

\begin{abstract}
Por toda parte, a verbiagem, oca, inútil e vã, a retórica, ora técnica, ora pomposa, a erudição míope, o aparato da sabedoria, uma algaravia afetada e ridícula, resumem toda a elaboração intelectual. $O$ verbocinante é o sábio. (...) Vem daí esta mania de citação (...); quem mais cita mais sabe, um discursador é um homem apto para tudo. Aceitam-se e proclamam-se os mais altos representantes da intelectualidade: os retóricos inveterados, cuja palavra abundante e preciosa impõe-se como sinal de gênio, embora não se encontrem nos seus longos discursos e muitos volumes nem uma idéia original, nem uma só observação própria. E disto ninguém se escandaliza; o escândalo viria se houvera originalidade.
\end{abstract}

Manoel Bomfim (1993)

Em janeiro de 1917, o primeiro número da revista Braziléa chegou ao público carioca prometendo uma verdadeira reviravolta no mundo dos periódicos, diários e magazines da cidade. Com a gravidade que a tônica nacionalista do momento exigia, seus diretores, Álvaro Bomílcar e Arnaldo Damasceno Vieira, cobraram seriedade e pensamento original no Brasil. Reagiam contra os procedimentos que julgavam típicos do trabalho cultural da ocasião - superexposição e vaidade ('Nosso programa', Braziléa, n. 1, 1917 , p. 3). Chegaram mesmo a elencar os 'mitos' que gozavam, no seu entender, de indestrutível prestígio, como Rui Barbosa na erudição, Clóvis Bevilacqua no direito, Farias Brito na filosofia, Alberto Torres na filosofia política, Rocha Pombo na história, Pedro Lessa no jurismo filosófico, Lauro Müller na política, Afonso Celso no civismo, Coelho Neto no romance, Olavo Bilac na poesia, Capistrano de Abreu na cronologia, Medeiros e Albuquerque na crítica literária e João do Rio no jornalismo.

No entanto, a despeito de toda a qualidade que reconheciam e respeitavam nos colegas citados, os diretores da revista argumentavam ser chegada a hora de romper com a exagerada reverência aos letrados brasileiros, como se figuras sagradas fossem a circular entre a Capital Federal e a Europa, numa "onda infernal de publicidade" (Variedades', Braziléa, n. 1, jan. 1917, p. 45). Sua implacável crítica se bifurca em dois caminhos. O primeiro resume-se a 
uma enorme indignação com os procedimentos tradicionais de consagração intelectual no Rio de Janeiro. O segundo caminho se refere à responsabilidade que atribuíram aos colonizadores portugueses no estabelecimento desse quadro que julgavam ser de improdutividade e atraso intelectuais.

Bomílcar, apoiando-se em Sílvio Romero e Alberto Torres, em vários números da revista, culpou os portugueses pela nociva tendência brasileira a dividir a sociedade em dois segmentos inconciliáveis: os senhores e os subalternos. No seu dizer, com a independência política de Portugal, com a libertação dos negros cativos e com o fim do regime monárquico e a instauração da República, os antigos senhores de terras teriam perdido a sua proeminência social. No seu lugar, uma nova elite urbana se estabeleceu como a detentora dos dividendos da respeitabilidade e prestígio públicos. Para novos tempos, novos aristocratas: teriam ascendido todos os que exerciam alguma atividade intelectual. Mais precisamente, os bacharéis. Em resumo: todos uns "declamadores hiperbólicos, tributários da 'gloriosa tradição portuguesa' - retórica e exagerada". Segundo Bomílcar, a ruidosa sociedade culta do seu tempo era só estardalhaço, propaganda, exibição e escravidão letrada a Portugal (Álvaro Bomílcar. 'A política no Brasil', Braziléa, n. 1, jan. 1917, p. 26-27).

Nessa divisão, que Bomílcar parecia fazer entre 'castas sociais', cabia ainda a constatação de que os retóricos brasileiros, com seus anéis de grau e diplomas, descenderiam diretamente dos portugueses e senhores de terras por sua postura social e pelo seu desprezo esnobe ao trabalho físico. Essa era, no seu entender, a psicologia do homo portucalensis transmitida aos brasileiros ('Variedades', Braziléa, n. 12, dez. 1917, p. 574, 581, 604608). Essa equação, histórica e cultural, foi partilhada, no entanto, por muitos outros autores.

\section{A Retórica Vinda de Portugal}

Bomílcar não foi o único a exigir novos tempos para a produção intelectual no Brasil. Posteriormente, todos os senões à educação clássica em humanidades foram igualmente aproximados do desprestígio do trabalho manual tanto por Sérgio Buarque de Holanda quanto por Gilberto Freyre. E não só isso: de acordo com dois dos maiores representantes das ciências sociais no Brasil, nas suas análises consagradas na década de 1930, os bacharéis e suas frases de efeito, pompa e circunstância seriam mesmo indissociáveis da herança colonial portuguesa (Holanda, 1982; Freyre, 2000). 
Sérgio Buarque de Holanda, por exemplo, encaminhou suas críticas à inteligência como "ornamento e prenda" para a sua proveitosa definição do Brasil como "terra de barões", analisando o quanto os títulos honoríficos funcionariam, entre os brasileiros, como indicativos exemplares da titularidade de qualidades pessoais. Do seu ponto de vista, no Brasil republicano, a carta de bacharel passou mesmo a substituir o título de nobreza. Por isso tantos pelejariam para tê-la, ou, ao menos, para aparentar possuí-la.

Buarque de Holanda também ressaltou que a cultura bacharelesca foi mesmo uma "tradição lírica que nos veio da metrópole". Mais fundamental ainda na sua obra é a análise da forte ligação entre o mero "amor às letras" e o desdém pela "nossa realidade cotidiana"; correlativo lógico, naquela fórmula, de uma intelectualidade "artificiosa e livresca", envergonhada do Brasil e enamorada da Europa (Holanda, 1982: 52, 116, 121).

Se passamos a Gilberto Freyre, veremos como sentenciou o conhecimento pela leitura de livros e sua exibição por formulações pomposas. Freyre também associou essa 'autêntica deficiência intelectual' ao preconceito ao trabalho físico, próprio aos portugueses e aos senhores de terras, estendendo-a aos bacharéis e demais homens cultos, todos avessos aos ensinamentos práticos e técnicos. Assentado nesse critério, Freyre argumentou que uma das faces da decadência do patriarcalismo foi o crescente poder e notoriedade sociais do 'burguês intelectual', ou do bacharel, e do militar, o 'doutor' da Escola Militar e da Politécnica. Uma vez perdida a condição privilegiada dos segmentos sociais decadentes, permaneceu, contudo, a resolução de se distinguirem por alguma força moral inalienável, semelhante, nesse caso, à nobreza de sangue. Daí a tão propalada 'inteligência'. Com o passar das décadas, no entanto, cada vez mais decorativa (Freyre, 1974, v. 1).

Outros intelectuais, no mesmo período e nas décadas seguintes, empenharam-se em revelar a vivacidade de tendências de pensamento ibéricas no Brasil. ${ }^{1}$ Além de Freyre e Buarque de Holanda, Manoel Bomfim, Oliveira Vianna e Fernando de Azevedo, por exemplo, também se ocuparam em discutir a colonização portuguesa e as possíveis 'características psicológicas' lusitanas legadas aos brasileiros. Nem mal irremediável, nem vantagem especial ou fonte de orgulho, diagnosticaram a herança colonial em ruralismo, retórica, ausência de espírito crítico, cordialidade, resistência ao progresso, desinteresse pelos métodos científicos, rejeição ao trabalho manual, apego ao dogma e à autoridade da tradição, cultura da personali- 
dade e excessiva afeição pela família. Procurando delimitar o que vinha de Portugal e o que tinha sido criado aqui, foram unânimes em defender a urgente instauração de novos fundamentos para as relações sociais, para as instituições políticas e para a produção intelectual no país (Santiago, 1989; Gomes, 1990; Lima, 1999).

Esse empenho discriminador entre Brasil e Portugal, por parte da intelectualidade brasileira do período, revelou-se em tiradas humorísticas, como as mencionadas no segundo capítulo, e em críticas veementes, como as que se seguirão. Apesar das evidentes diferenças, humorismo e censura grave podem ser reunidos num mesmo registro discursivo graças à associação feita entre 'enciclopédicos' e herança colonial portuguesa. Do alto das suas pretensões profissionalizantes, o mundanismo literário beletrista e a produção intelectual que, então, se autoqualificava como 'moderna' e 'científica', aproximam-se na desqualificação aos enciclopédicos e ao seu pretenso amor ao aristocratismo, às aparências, ao prestígio social, à bibliofilia, à posição de destaque, à exibição de vasta instrução, à memória, ao poligrafismo, à verborragia e à oratória inflamada. Nessas formulações, os enciclopédicos seriam uns provincianos, insistindo em causar rumor à sua passagem. Ocorre que, na verdade, num espaço estranho à sua sociabilidade intelectual Ancien Régime, a insistência em bem aparecer em público, as motivações em impressionar e ensinar o auditório, o cultivo da cultura geral, o culto da beleza da expressão ligado ao prazer e à arte de viver passaram a significar galanteios vistosos, distrações, gosto pelo luxo, pelos altos postos, pelo fausto e seus esplendores, pelas teatralidades das relações sociais, pela dissimulação e pelos primores do bem falar. De onde a percepção generalizada de que 'enciclopédicos' e 'retóricos' seriam uns 'frívolos deslumbrados', e, o pior, uns 'atrasados', tipos aportuguesados que teriam perdido a hora e o tom apropriados àqueles novos tempos.

Por tudo isso, nas cada vez mais circunscritas seções de ciência dos jornais e revistas, acumulavam-se censuras veementes contra a cultura geral dos retóricos. Mesmo os "diletantes" ou os "curiosos das idéias gerais" e "discípulos de várias escolas", outrora tipos da mais alta categoria, dado o seu incansável empenho intelectual, passaram a ser qualificados como "filósofos baratos" (João Ribeiro. 'A filosofia no Brasil', Revista do Brasil, n. 22, out. 1917, p. 255).

Essa reviravolta na história das idéias no Brasil foi encarada no próprio conceito da época como uma profunda divergência entre dois momentos 
totalmente inconciliáveis. Sérgio Buarque de Holanda e Múcio Leão, por exemplo, chegaram mesmo a elencar essas diferenças, classificando-as como desacordos geracionais, se não mesmo como "duas mentalidades que se chocam" (Holanda. 'O lado oposto e outros lados', Revista do Brasil, n. 3, out. 1926, p. 9; Leão. 'Roteiro de duas gerações', A Manhã, ago. 1942 , p. 22). Na sua acepção, o pasmo com tantas leituras pessoais não era de se estranhar numa terra como o Brasil em que aplaudiriam aos brados, como o maior erudito entre todos, "um imperador que nunca escreveu uma linha de ciência, ou deu outra prova inconcussa do seu saber" (José Veríssimo. 'Uma lenda literária', Renascença, n. 25, mar. 1906, p. 93). Um cronista do período chegou mesmo a afirmar que o Imperador fora destronado pelo gênero de estudos enciclopédicos a que se dedicava, o que acabou por sua vez contribuindo para o próprio desgoverno da Monarquia (Joaquim Vianna. 'Porque caiu o Império?', Almanaque Garnier, 1909, p. 273-274).

As cobranças e as retificações a Pedro II como um dos grandes expoentes da inteligência brasileira atestam também mudanças intelectuais. Sua notoriedade como amigo das letras, senão ele mesmo como legítimo homem de letras, não sofria contestações mesmo no limiar da República. Todavia, com o passar dos anos, já começavam a dar conta do exagero ou da impertinência da sua exemplaridade como um dos maiores sábios brasileiros. Ao contrário dos tempos áureos da retórica, a autoridade moral do letrado já não assegurava mais a qualidade das suas idéias, e sequer legitimava a sua exposição pública. O que se questionava no mesmo movimento eram os atributos e os critérios de consagração dos homens de letras "como eles próprios se apelidam, cheios de vacuidades, de todas as fumaças e pretensões de grandeza" (Ś́lvio Romero. 'O Brasil social', Renascença, n. 27, maio 1906, p. 242). Ocorre que a 'vastidão' na formação intelectual e no domínio de conhecimentos tão díspares passou a ser, de qualidade pessoal digna de toda sorte de admiração, sinônimo de indisciplina mental, passadismo, anarquia social e desprezo pelas realizações práticas. Vícios imediatamente associados aos "profissionais da politiquice, bacharéis e escrivinhadores famintos" (José Maria Bello. 'A missão das nossas elites', Revista do Brasil, jan. 1919, p. 112). Vale frisar que a censura à retórica e ao tom empolado dos discursos era indissociável tanto da sua crítica ao exagerado personalismo do debate cultural quanto ao pretenso caráter discricionário, nobiliárquico e pouco original do exercício intelectual no Brasil. 
Inclusive nas escolas, tamanho cultivo de vários ramos do saber vinha sendo posto em questão sob pena de precipitar nas crianças um legítimo esgotamento nervoso. "Programas de ensino pletóricos", baseados em sistemas de enciclopedismo, exigiriam dos alunos uma imobilização muito demorada nos bancos das escolas dada a infindável quantidade de informações a reter. Em casos similares, a estafa física e mental das crianças seria plenamente compreensível. Nesse contexto, Fernando de Azevedo sentenciou: "não se deve sacrificar a humanidade às humanidades". O que chamou de o "regime pletórico de ensino" era, do seu ponto de vista, absolutamente contraproducente, provocando nas crianças um enjôo físico dos estudos, martirizando-as na verdade já que obrigadas a "amalgamar no espírito" conhecimentos dos quais nunca mais fariam uso em toda vida (Fernando de Azevedo. 'Educação higiênica', Revista do Brasil, maio 1917 , p. 76-77). ${ }^{2}$

Tal discussão refere-se à crítica aos currículos das escolas primária e secundária, mas principalmente desta última. Para se ter uma idéia, o ensino secundário, desde as últimas décadas do século XIX, exigia a freqüência em cursos de português, latim, grego, francês, inglês, alemão, matemática, astronomia, física, química, história natural, biologia, sociologia e moral, geografia, história universal, história do Brasil, literatura nacional, desenho, ginástica e música. Era contra essa combinação entre ciências e humanidades clássicas, com especial prejuízo das primeiras, que Azevedo estava a reagir. Insuflada por todas essas censuras, a reforma João Luís Alves-Rocha Vaz, de 1925, decreto n. 16.782-A, reorganizou a distribuição das matérias, tornando facultativa a freqüência em alguns cursos de línguas estrangeiras. Para tanto, essa reforma propôs o seguinte currículo: português, latim, literatura brasileira, literatura das línguas latinas, francês, inglês, alemão (facultativo), italiano (facultativo), filosofia, história da filosofia, sociologia, instrução moral e cívica, história universal, história do Brasil, geografia geral, corografia do Brasil, cosmografia, aritmética, álgebra, geometria, trigonometria, desenho, física, química e história natural. Pretendente a instaurar um ensino mais 'científico', a reforma manteve as matérias relacionadas às letras, mas aumentou o número das horas semanais das disciplinas de ciências (Alves, 1990; Nagle, 1997).

Em meio à discussão sobre a instauração de uma educação que promovesse a observação, estimulasse as 'aptidões naturais' dos alunos e atendesse às necessidades de uma sociedade moderna, pode-se mais uma vez 
atestar a conformidade no emprego das palavras 'literatura', 'humanidades' e 'retórica', utilizadas como se possuíssem indistintas significações. A própria Diretoria Geral da Instrução Pública optou por difundir nas escolas públicas do Rio de Janeiro somente os livros que não fossem demasiadamente 'generalistas' e 'literários', ou seja, somente os escritos em "linguagem clara e singela". ${ }^{3}$

De acordo com notícia propagada numa revista que circulava na cidade, a intenção da Diretoria era a de não exaurir as crianças, tirandolhes o gosto pelo estudo. O que ocorreria por lerem uma literatura afetada, cheia de estrofes lacrimejantes e de temas repetitivos como o 'do menino que matou o passarinho'. Tudo isto lhes daria uma visão postiça e simplória da realidade. E a literatura transformava-se na malfadada retórica quando definida por suas "descambatórias românticas", por seus "arranques de lirismo" ou por seu "estafado recurso dos fogos de vista e girândolas verbais". Artificiosa e livresca, essa literatura plasmaria desde cedo a cerebração das crianças, desenvolvendo nelas grande pieguice e "um prisma lambuzado de sentimentalismo" (Américo Bruschini. 'Literatura nas escolas', Revista do Brasil, n. 85, jan. 1923, p. 64-66). Não surpreende, portanto, que os brasileiros não conseguissem livrar-se da pecha de 'povo de retóricos'. Como se não bastasse a herança colonial, seriam enfileirados, já na infância, para esse destino.

Apesar da solitária alusão, pode-se notar que até mesmo a Diretoria Geral da Instrução Pública pretendia reverter essa suposta fatalidade, dando chances às crianças de desenvolverem, quando adultos, outras aptidões e carreiras intelectuais. O que não mais se concebia era que os brasileiros só "soubessem produzir literatura", ou seja, que se expressassem escrita e oralmente por meio de palavras sonoras (Américo Bruschini. 'Literatura nas escolas', Revista do Brasil, n. 85, jan. 1923, p. 64-66).

Muito mais poderia ser dito sobre os estudos no Brasil, por não conformarem cursos "de preparo prático e inteligente para a vida diária". As motivações para quem se dispunha a estudar resumiam-se basicamente a satisfazer "a manhosa vaidade paterna" e a usufruir da mesada familiar e da ociosidade doméstica. Otimizando a cultura geral, estudos deste tipo atrofiariam desde o cérebro do indivíduo até todo o desenvolvimento do meio social. Para tantas perguntas sobre a finalidade da "inerrância absoluta, da sagacidade inexcedível e da competência universal" dos doutores e homens de letras brasileiros, a resposta redundava tão simplesmente em: 
ou aspirar à glória de "encher o mundo de frases sonoras"; ou de se "revelarem inteligentes em balbuciar banalidades em algum brinde de sobremesa"; ou bem em "destrinçar charadas do Almanaque de lembranças e de outras publicações do gênero". Assim, para compensar sua total falta de préstimo, um cronista do período sugeriu que afinal virassem temas de carnaval, onde ao menos as "casacas imemoriais dos doutores e as suas cartolas hediondas e os seus óculos e barbas veneráveis" pudessem ser arrastadas ruas afora divertindo o povo, e pela galhofa fazendo-lhe justiça (Joaquim Vianna. 'Psicologia do bacharelismo', Almanaque Garnier, n. 8, 1910, p. 102-104).

Tudo isto porque, seguindo umas somas exageradas, o Brasil seria mesmo o país mais saturado de bacharéis em todo o planeta (Plínio Barreto. 'Evolução das profissões', Revista do Brasil, n. 83, nov. 1922, p. 266). Os brasileiros encorajariam, por orgulho vão, o triunfo permanente dos doutores, e de que afinal lhes serviria tamanha proeminência uma vez que os bacharéis se tinham tornado sinônimo de uma cultura enciclopédica e inútil; na verdade, exagerada diante de tantas demonstrações públicas de sapiência?

Se na virada do século, o título de 'doutor' só era concedido àquele que havia recebido 'solenemente' o elevado grau acadêmico, o qual, aliás, outorgava-lhe o direito de ensinar os saberes nos quais fora graduado, nos tempos a que se está a se referir, a palavra tinha-se tornado apelido dos mais irônicos para caracterizar os indivíduos que se presumiam muito sábios e espertos, que falavam muito e em tom sentencioso, apressados a dar conselhos e a demonstrar conhecimentos sobre todos os assuntos. Ao bacharel, naquela quadra, atribuía-se rigorosamente a mesma presunção, prestando-se o termo à zombaria de qualquer tagarela que "alega muitas razões e nada prova" (Cardoso Franco. 'Língua vernácula', Revista do Brasil, n. 55, jul. 1920, p. 249-250). ${ }^{4}$

A sensação difusa do período - a de que existiriam bacharéis em excesso - não era totalmente inexplicável. Quanto a isso, basta lembrar as sucessivas leis que acabaram por instituir a desoficialização e a liberdade de ensino no Brasil. As reformas Benjamin Constant, de 1891, e Rivadávia Correa, de 1911, estabeleceram que qualquer indivíduo ou associação particular poderiam abrir cursos ou estabelecimentos de instrução superior, retirando dos centros federais o monopólio do ensino em direito, medicina e engenharia. Com tudo isso, só cresceu a impressão de que se vivia numa 
sociedade marcada por uma verdadeira inflação de diplomas, corroborando ainda mais, inclusive, a baixa cotação dos bacharéis e doutores, sobretudo daqueles oriundos das escolas de direito, em tese, os mais palavreadores (Santos, 1922; Miceli, 1979; Nagle, 1997; Coelho, 1999).

\section{Modernos e Especializados}

$\mathrm{Na}$ argumentação dos pretendentes à especialização intelectual, o esgotamento dos bacharéis se explicaria por já terem ultrapassado no Brasil o 'período romântico da vida', quando as palavras significavam mais do que os atos. E o argumento é por deveras recorrente para ser neglicenciado. Como já se sabe, a definição naturalista para o romantismo atribuiu-lhe uma tal afetação da linguagem que acabou por tornar indistintas, no emprego e na acepção das gerações seguintes, a literatura romântica, o beletrismo e a retórica. No entanto, se 'retórica e romantismo' se aproximavam é porque se referiam ao mito do saber espontâneo, à valorização do cultivo da subjetividade do indivíduo e ao desenvolvimento da riqueza interior em toda a sua profundidade e complexidade (Löwy \& Sayre, 1992), valores que começaram a perder a sua proeminência no debate intelectual. E como a especialização científica, exatamente, corria a passos largos, a insistência em cultivar uma educação humanista toda feita de latim, grego, literatura e filosofia parecia não só inútil como totalmente anacrônica. Como pretender conhecer tudo, como uma legítima enciclopédia do século XVIII, a despeito da tecnização do saber científico? A mobilidade dos tempos modernos não se coadunava mais, no entender dos aspirantes à especialização, com tanta impenetrabilidade de idéias, com a perda de tempo que o meneio constante dos textos requeria para a sua decifração.

Todo esse mal-estar, alimentado pelo romantismo e seu reforço do ideal do 'saber total' como um modo de elevar as almas a uma ordem superior de existência, não se restringia unicamente às fronteiras do saber. Estados de alma, crenças e fundamentos tidos até então como inatingíveis sofriam de uma crise de confiança. Conjuntura que redundava na consideração de que a filosofia, o gosto clássico, os valores da cultura humanista e a aspiração de controlar domínios múltiplos do saber estavam igualmente em apuros nesses tempos de tantas reviravoltas epistemológicas. Num mundo mental em que começava a reinar a especialização, como pretender estabelecer uma aliança com a plenitude e riqueza dos segredos do universo, união transformadora para o completo florescimento do 'eu'? 
Como encarar o conhecimento como uma dádiva e não como uma conquista arrancada à natureza, todos esses fortes ideais românticos (Gusdorf, 1982; Martin-Fugier, 1998; Candido, 2002)?

E não por acaso, os ditos 'intelectuais modernos' descreviam os 'românticos enciclopédicos' contemplando o passado, enquanto procuravam agir e intervir na ordem do mundo de modo a apressar a chegada do futuro. E toda a valorização dos "homens de ação", seus "heróis prediletos", relacionava-se à introdução do chamado "ideal democrático" em grande parte das discussões atinentes às profissões (Plínio Barreto. 'Evolução das profissões', Revista do Brasil, n. 83, nov. 1922, p. 267). Imprescindível que fossem, todas, niveladas, num universo mental que começava a amoldarse pela racionalização, pela especialização das atividades e funções, pelo encanto com a técnica que os distanciava do ritmo da natureza, e, sobretudo, pela positividade da divisão do trabalho e da interdependência das relações sociais como critérios fundamentais a atestar o padrão de progresso de uma sociedade (Simmel, 1975; Prochasson, 1991; Coelho, 1999). Mesmo a discussão, no Brasil, sobre a civilização ganhou esse indispensável adendo, pela crescente diversificação social nos países que almejavam alcançar. Mas não só isto, o desenvolvimento da tecnologia e dos sistemas de comunicação, o crescimento urbano e a mudança de vastas paisagens nos países que os inspiravam, começaram, pois, a lhes apresentar novas necessidades e novos padrões de equiparação que, cada vez menos, combinavam com o mundo em que os bacharéis eram 'deuses'.

O que vale reter nesse ponto é a definitiva falência dos temas, das imagens e dos procedimentos intelectuais tradicionais. A modernização, com seus automóveis, telefones, bondes, fotos, cartazes, cinematógrafos, motores e trens, ao exigir uma nova percepção do tempo como movimento, descontinuidade, velocidade, pressa, instantaneidade, mudança e sede por novidades, abalou sobremaneira o antigo padrão de produção intelectual, até então assentado na idéia de uma formação longa e completa de estudos e no modelo de um saber enciclopédico, tomado como critério discriminatório e hierarquizante. Contestada, essa pauta de julgamento do mérito começou a ser discutida e reformulada. Além disso, deu-se a transição para novos padrões de pensamento, percepção, gosto e ação, que, aliás, se disseminaram muito rapidamente ${ }^{5}$ - a percepção do encolhimento das distâncias e a sensação da velocidade do tempo seguiam se impondo (Simmel, 1975; Lipovetsky, 1987; Benjamin, 2000). E mais: esse surto de 
'mecanização da vida' cooperou para a intensificação de um sentimento de triunfo, totalmente incompatível, pensava-se na virada do século XIX para o XX, com a 'metafísica' da 'velha' herança literária portuguesa (Candido, 1967; Coelho, 1999). ${ }^{6}$ E não só aqui no Brasil, mas em todo o Ocidente a força da expressão 'tempos modernos' vinha impingindo a compreensão de todas essas décadas como totalmente apartadas das precedentes. Na verdade, seriam mesmo o seu contrário: além de mais 'novas', 'melhores'.

A propósito, não se devem neglicenciar o valor e a força que a idéia de 'novidade' tinha no imaginário dessa época. Atesta a sua perfeita integração à consciência dos homens do período a ênfase das expressões empregadas para representar as noções de 'mudança', de 'aceleração' e de 'rapidez', tais como revolução, progresso, desenvolvimento e crise. Todos esses conceitos certificam a dinamização da idéia de tempo e uma otimização dos seus atributos históricos, ou, em outras palavras, da sua própria transitoriedade (Koselleck, 1990). ${ }^{7}$

Os intelectuais percebiam que o próprio pensamento deveria encarnar esse movimento acelerado da história; por isso a urgência em reexaminar um mundo que lhes parecia excessivamente instável (Charle, 1996). Nesse período, tudo o que se relacionava ao moderno passava a se contrapor, automaticamente, às idéias de fixidez e de imobilidade.

Aliás, a noção de tempo passava, então, a ser entendida como uma abstração em que várias atividades diferentes, como morar, comer, vestir, trabalhar, estudar, fazer compras ou passear, deveriam se inter-relacionar. E dessa diversificação das ações nasceu a necessidade de um parcelamento das tarefas como o único modo possível de bem aproveitar o tempo. Adaptar-se ao seu ritmo veloz, realizando todas essas pequenas e múltiplas ocupações cotidianas, era uma questão fundamental. Quanto mais não seja, a possibilidade de 'perder tempo' significava estar em verdadeiro descompasso com a ordem do mundo (Gille, 1978; Landes, 1983; Thompson, 1984; Munford, 1987; Ortiz, 2003).

Afora isso, novas formas de lazer foram incorporadas ao cotidiano da cidade do Rio de Janeiro, expondo a leitura e a escrita, por exemplo, à concorrência do cinematógrafo, da fotografia, dos reclames e do gramofone. Inevitável salientar o caráter audiovisual dessa nova subjetividade e dessa nova forma de compreensão do mundo que se fortaleceu com a modernização da cidade nas primeiras décadas do século XX, esvaziando a disponibilidade para a contemplação, para o polimento e para a reflexão que o 
antigo fazer literário exigia. Sob esse padrão mental, a transformação irrompia como sinônimo do efêmero, criando uma nova sensibilidade mais adaptada ao múltiplo, à variedade das imagens em mudança, e ao intenso intercâmbio social, transitório e impessoal (Simmel, 1975).

Mesmo a obrigatória musa inspiradora já não era mais a mesma. Com a padronização das modas e a aceleração moderna do ritmo da vida cotidiana, findaram todo o langor romântico e o pessimismo dos espíritos deprimidos, e a sua imagem já não era a de uma mulher como que "enlutada e dolente, de tez pálida e olhos ternos". Na verdade, a inspiração nasceria da própria vivência frenética das cidades, germinando coragem e energia no coração dos homens; novo mundo em que a "cultura e o refinamento não bastam para dar significação a uma vida; tampouco lhe bastam as aspirações ideais". Em suma, o fim do homem da cidade moderna seria agir e não especular. Não haveria mais como dispor de muito tempo para o deleite dos encantos e frescura da vida, para a "contemplação da candura aveludada das pombas" (Xavier Marques. 'A poesia da ação', Ciências e Letras, n.12, fev. 1914, p. 4-5).

O pretenso sentimentalismo dos romances passou a ser considerado uma verdadeira difamação. Fora de moda tornaram-se igualmente as ternuras do namoro, entendidas como de uma pieguice insuportável, assim como os temas das 'noites de luar' e 'oceanos revoltos', ou onde havia sempre um "mancebo caído de joelhos aos pés de alguém" ('O romance', Careta, n. 9, ago. 1908. Como se percebe, foram-se esvaziando os motivos literários tradicionais (Sevcenko, 1995).

Some-se a isso, a alteração dos atributos necessários à criação mental. Tomando Rui Barbosa como o maior exemplo do letrado brasileiro de formação enciclopédica, impossível não mencionar sua notabilidade como uma "cerebração extra-comum", "uma memória que dificilmente se encontra"; memória que lhe permitiu ser a "mais vasta erudição do Brasil", senão mesmo de toda a Terra! À parte isso, era tido como orador de altíssima cepa, cujo talento só poderia ser rivalizado por Cícero e Vieira (Moacir Silva. 'Rui Barbosa como poeta', Revista do Brasil, n. 94, out. 1923, p. 119). Acrescentem-se, inclusive, os abundantes comentários de que uma vasta ilustração como a de Barbosa só era possível em países que ainda não teriam feito a divisão do trabalho intelectual. E urgia, portanto, adotála. E, como na fórmula dos aspirantes à especialização, generalidade intelectual e falta de préstimo social eram sinônimos inseparáveis, bradava-se 
que a produção cultural brasileira não poderia mais ser realizada com afetação e por diletantismo, como art d'agrément, como o piano ou os bordados, mas, ao contrário, como um mister exercido por vocação e com seriedade (José Veríssimo. 'O movimento literário brasileiro em 1910', Revista Americana, n. 4, abr. 1911, p. 6-14; Afonso Celso. 'Trabalho intelectual: crise de que se sofre. Como remediá-la', Revista do Brasil, n. 88, abr. 1923, p. 374). Constata-se, assim, a variação do valor da instrução, segundo a qual a boa memória era requisito fundamental de uma boa inteligência, os livros, seu mais elevado instrumento e a vasta ilustração somada ao verbo fácil, os seus mais notáveis resultados. Mas nada disso é efetivamente inédito, pois a disposição em criar novos critérios para o exercício da atividade intelectual já havia começado nos últimos decênios do século XIX, conforme se viu nos capítulos anteriores e como ainda se verá no capítulo seis. No entanto, as polêmicas cresceram consideravelmente com o passar dos anos, e nelas já se podem mapear alguns dos personagens que tomaram a frente da cena e dos debates em torno da especialização disciplinar. E mais uma vez, o bacharel foi o alvo preferido do deboche por encarnar a inutilidade de um padrão de inteligência todo permeado de sofismas apenas para adensar a aparência do que se diz.

Bem, não pode ser outra a conclusão a que se chega: se não efetivamente uns bastardos sociais, os bacharéis e homens de letras enciclopedistas tornaram-se uns 'bastardos epistêmicos'. ${ }^{8}$ Nem mais nos cartões de visita, que trocavam com tanta freqüência, os intelectuais ousavam utilizar denominações tornadas tão ambíguas.' A expressão 'homem de letras' passou a ser somente uma veleidade, e não um designativo que informasse o exercício preciso de uma atividade, intelectual ou profissional. E não só no Brasil. Com a crescente profissionalização da atividade intelectual no século XIX europeu, expressões como 'homens de letras' e 'homens de ciência' perdem força (Charle, 1990). E isto, por terem designado, até o setecentos, uma situação em que homens, no âmbito privado, cultivavam leituras e saberes, sem que isso fosse uma necessidade financeira. Esse cultivo privado de conhecimentos em nada se confundia com a esfera pública dos negócios, nem dela resguardava-se como 'lazer'. As letras eram associadas à pessoa natural ('homem de...') em lugares de sociabilidade onde a 'assimilação privada de saberes' circulava, era comunicada e discutida publicamente. Ou melhor, numa configuração histórico-social em que pessoas privadas 'queriam se encontrar como seres humanos', e na qual a cultura era 
entendida como 'uma experiência que se acumula'. Não se pensava em termos de esferas estanques de produção, de um lado, e de consumo de cultura de outro (Habermas, 1984).

No entanto, com a profissionalização, os segmentos sociais letrados deixaram de ser os que faziam um uso público da sua razão privada para se constituírem, cada vez mais, em minorias de especialistas cujo saber era remunerado e inteligível para públicos muito específicos e fragmentados (Habermas, 1984). A propósito, a ironia do escritor francês J.-H. Posny, que replicava a Balzac a criação da sua Société de Gens de Lettres na segunda metade do século XIX, segue na mesma direção à especialização intelectual que também ganhava terreno no Brasil: "Não é propriamente uma Sociedade dos Homens de Letras que deveria existir, mas uma associação para desencorajá-los a tornarem-se homens de letras" (Benoît, 1936).

Tantas caricaturas e descomposturas significam, na verdade, que essa representação não indicava mais a contento as novas identidades profissionais em gestação. E isto num contexto regido pela importância dos recursos intelectuais como fator de desenvolvimento nacional, mas também pela imprecisão das antigas expressões e imagens, ainda dominantes na linguagem corrente da sociedade, e seu lento divórcio da nova situação, na qual o ideal do profissional especializado já começava a se impor.

\section{Notas}

1 Essa tendência perdura ainda em teóricos das ciências sociais no Brasil graças à discussão reanimada por Richard Morse (1988) em controverso livro. Tomando a Idade Média como baliza temporal e origem comum, o autor subdividiu a civilização ocidental, no limiar da modernidade, em duas experiências históricas "invertidas como num espelho" - a anglo-saxônica e a ibérica. Oriundas de uma mesma matriz cultural, entre os séculos XII e XVII, essas tradições de pensamento teriam, segundo Morse, optado por direções distintas - a primeira seguiu o rumo das revoluções religiosa e científica; a segunda, configuradora da América Latina, continuou inscrita (ainda que com algumas reformulações) no tomismo e na escolástica. Afora toda a polêmica suscitada pela boa adjetivação que Morse propôs da herança ibérica (e que, em séries de análises, parece ser a fonte inesgotável de obscurantismo e de todo o pretenso retrocesso brasileiro), o tema foi incorporado na análise do pensamento político a partir do debate entre americanistas e iberistas e das suas diferentes concepções de Estado, indivíduo, liberdade e cidadania. A esse respeito, o texto mais significativo é o de Vianna (1997).

2 Azevedo teve grande participação nas reformas educacionais realizadas no Rio de Janeiro e em São Paulo nas décadas de 1920 e 1930, incluindo revisões curriculares 
nos cursos primário e secundário e a construção de espaços específicos nas escolas para a aprendizagem de ciências naturais, para exercícios físicos e aulas. Foi um dos signatários e principais redatores do Manifesto dos Pioneiros da Educação Nova, lançado em 1932, tendo sido ainda um dos fundadores da Universidade de São Paulo (USP). Suas idéias pedagógicas incluíam forte crítica à predominância das humanidades nos currículos escolares.

3 Sobre essa e outras reformas no ensino público da Capital, ver Antonio Carneiro Leão ('O ensino municipal no Distrito Federal', A Educação, ano IV, v. IX, n. 3, mar. 1925, p. 181-209).

4 O dicionário de Laudelino Freire demonstra: a palavra 'bacharel' passou a ser empregada para fazer referência a todo 'indivíduo tagarela'. Mais importantes, no entanto, são os neologismos pejorativos criados a partir da palavra: bacharelar (falar muito e fora de propósito), bachareleiro (palavroso, discursador), bacharelice (costume de falar à toa) e bacharelada (palavras ridículas ditas com presunção de serem acertadas e sábias; discurso impertinente e pretensioso. Palavreado enfadonho). Cf. Freire (1954: 934, v.2). Com a palavra 'doutor' ocorreu rigorosamente o mesmo: doutoraço (homem que ridiculamente se presume sábio), doutoral (que tem gravidade pedantesca), doutorice (modos ou ares de doutor. Parlapatice; ditos de sabichão) e doutorismo (predomínio dos doutores; bacharelismo). Da palavra retórica também nasceram expressões com novos significados pejorativos, tais como 'retoricador' (palavreador, tagarela), 'retórico' (falador, que tem estilo empolado ou pretensioso. Orador que declama afetadamente ou em estilo empolado e impróprio) e 'retoriquice' (demasiada ou falsa retórica - 1954: 4445-4446, v. 5). Cf. Freire (1954: 2007, v. 2).

5 Esse horizonte da modernização técnica e urbana imprimiria, no mesmo sentido, novas formas, mais fragmentárias, de compreender o tempo, um novo olhar para a cidade, enfim, um novo redimensionamento da subjetividade (Hardman, 1988).

6 É no que se refere à reavaliação dessa 'bagagem genética' ibérica que se pode pensar numa comunidade de discurso, senão mesmo numa 'geração' no interior da qual esses sentimentos de êxito e superioridade em relação ao passado funcionaram como elementos catalisadores. Sobre a delimitação dos intelectuais em grupos e em gerações, ver Sirinelli (1987).

7 A súbita percepção da crescente aceleração do tempo já aparecia em crônica de Machado de Assis publicada em 1894 na sua coluna "A Semana": "Mas então que é o tempo? É a brisa fresca e preguiçosa de outros anos, ou este tufão impetuoso que parece apostar com a eletricidade? Não há dúvida que os relógios, (...), andam muito mais depressa" (apud Hardman, 1992: 291).

8 A expressão é de Prochasson (1991: 175).

9 Nos arquivos pessoais dos membros da ABL, uma infinidade desses cartões de visita pode ser encontrada. Afinal, era por meio deles que, gentilmente, pediam votos para si mesmos e para os amigos. Em épocas de eleições para a Academia, esses pequenos cartões circulavam em todos os meios letrados da cidade. 



\title{
Uma Multídão de Idéias Novas
}

\begin{abstract}
L'époque actuelle constitue un des moments critiques où la pensée humaine est en voie de transformation. Deux facteurs fondamentaux sont à la base de cette transformation. Le premier est la destruction des croyances religieuses, politiques et sociales d'où dérivent tous les éléments de notre civilisation. Le second, la création de conditions d'existence et de pensée entièrement nouvelles, engendrées par les découvertes modernes des sciences et de l'industrie. Les idées du passé, bien qu'ébranlées, étant très puissantes encore, et celles qui doivent les remplacer n'étant qu'en voie de formation, l'âge moderne représente une période de transition et d'anarchie. ${ }^{1}$
\end{abstract}

Gustave Le Bon (1981)

Na página de abertura do primeiro número da revista parisiense Je Sais Tout, vê-se o desenho de um homem em trajes de 'dândi', enorme cabeça em forma de globo terrestre, olhos fechados, indicador à testa, fisionomia concentrada e leve sorriso nos lábios. Na mesma edição, de 1905, pode-se ler uma entrevista com Santos Dumont, o notável aviador, dando notícia dos progressos brasileiros e do tão 'maravilhoso' processo de aplicação e desenvolvimento original das sabedorias aprendidas na Europa. Nada mais coerente com os objetivos da revista, já nos mostra sua ilustrativa capa, de reunir o conjunto dos conhecimentos humanos e os eventos científicos universais, que dar a palavra a um inventor de muito sucesso, chamado ali a relatar suas novas criações. ${ }^{2}$

Amparado pelo espírito científico da época, Santos Dumont contou estar preparando uma residência dirigível que, por seu conforto e rapidez, se imporia às ferrovias e demais transportes terrestres e contribuiria para a definitiva e irreversível conquista do ar. Dumont vislumbrava a ampla circulação pelos principais centros urbanos do mundo, por trabalho e a passeio, como nos mostra inclusive um outro desenho que acompanha a sua entrevista e no qual se vê, como exemplo, o pleno funcionamento de uma estação aérea no alto da catedral de Notre Dame de Paris! ${ }^{3}$ 
A desproporcional estação aérea na catedral dá bem o tom da voga científica do período que não conhecia, como nós, é certo, a sagração do patrimônio. O que vale reter, nesse caso, é a certeza geral na capacidade humana de confeccionar invenções cada vez mais revolucionárias e inovadoras. No seu depoimento à revista francesa, Santos Dumont assegurava que transformações desse tipo eram uma constante entre os brasileiros, tendo a modernização se tornado algo absolutamente natural aos seus olhos (Je Sais Tout, n. 1, fev. 1905, p. 105-110).

Como se vê, no Brasil, mas também na Europa, a virada do século XIX para o XX pode ser caracterizada por uma sorte de fascínio pelas descobertas científicas. A ciência era considerada, simplesmente, a mais elevada manifestação da inteligência humana. Tinha a missão suprema de informar a origem e o futuro dos homens e do universo, tendo ainda a responsabilidade de ditar as regras de bom comportamento para toda a sociedade (Paul, 1992). Nesse período, toda forma de conhecimento que pretendesse estabelecer alguma verdade deveria apresentar-se como 'científica' a fim de garantir a sua reputação. O termo 'ciência' constituía o ponto de referência obrigatório que muitos empregavam para conferir validade objetiva e soberana ao seu discurso (Gillispie, 1960; Biard, Bourez \& Brian, 1997).

\section{Ciência, Progresso e Modernização}

A enorme legitimidade da ciência no Ocidente deve ser relacionada ao acachapante triunfo da mecânica, da termodinâmica e da geometria, ao êxito da análise do movimento dos corpos celestes, e, acima de tudo, ao método experimental e indutivo das ciências naturais que impressionaram o mundo oitocentista. E no que se refere a elas, seu progresso era incensado naquela segunda metade do século XIX, particularmente nas revistas grande público que se ocupavam em difundir a enormidade das suas descobertas.

A ciência, 'fonte única do progresso', estava presente ainda nos textos e nas imagens dos livros, revistas e jornais do período. Suas crescentes inovações técnicas, como as pontes suspensas, as máquinas a vapor e as ferrovias, por exemplo, habilitavam-lhe a se apresentar como a própria bandeira da civilização, tanto quanto ainda como o agente indispensável para uma reorganização completa das sociedades (Panza \& Pont, 1995). 
Nessa ocasião, a certeza científica se instalou na produção do conhecimento em todas as áreas. Nada mais coerente com esse espírito do que a confortável declaração do cientista francês Marcellin Berthelot em fins do século XIX: "Não há mais mistérios no mundo". ${ }^{4}$ Sua síntese mais expressiva encontrava-se na fórmula 'razão = ciência $=$ tecnologia $=$ progresso = futuro' (Boia, 1999).

Com o amplo desenvolvimento da técnica, a imagem forte da ciência - de transformação e comando da natureza - impôs-se na indústria, na literatura e nas mentalidades. O século XIX, em especial a sua segunda metade, foi também a época de ouro da 'vulgarização científica'; termo que denotava, na ocasião, o que hoje conhecemos como divulgação pública dos conhecimentos científicos. A ampla proliferação do romance científico, da ficção científica, de conferências, cursos, museus e exposições sobre hipóteses então em voga configuraram uma abertura e uma afirmação sem precedentes do seu imaginário triunfante (Boia, 1999). Para ilustrálo, o dizer de um dos seus entusiastas, Ernest Renan: "o mundo que a ciência nos revela é muito superior ao mundo fantástico criado pela imaginação" (apud Béguet, 1990: 23).

Esses tempos foram marcados também pelo crescente descrédito da filosofia. ${ }^{5}$ Alguns chegaram mesmo a preconizar o seu completo desaparecimento. Fazer ciência na Europa desse período significava renunciar a todo pressuposto filosófico, ou metafísico, para então substituí-lo pelo método das ciências naturais (Cresson, 1905; Papini, 1906; Freuler, 1995).

Afora isso, em 1859, publicou-se o revolucionário livro de Charles Darwin, A Origem das Espécies. Darwin ressaltava a implacabilidade da historicidade da natureza, até então pensada como imutável e harmoniosa (Mayer, 1987). Era o mundo em que reinava também o procedimento crítico de Hippolyte Taine, convidando os intelectuais a estudarem o temperamento e as modificações profundas dos organismos sob a pressão do meio e das circunstâncias. Na França, o literato naturalista Zola agia como um verdadeiro profeta de uma revolução copérnica: "o homem metafísico está morto!" (Beaumarchais, Couty \& Rey, 1994: 1726).

Isso tudo sem contar a fisiologia de laboratório desenvolvida por Claude Bernard e a revolução perpetrada por Pasteur no âmbito da medicina. Com o advento da bacteriologia no final do século XIX, a medicina pastoriana foi, crescentemente, tomando o centro do foco científico, imprimindo e modificando conceitos nas ciências naturais, especificando a 
natureza microbiana das doenças e indicando terapêuticas baseadas nesse novo princípio científico. A medicina preventiva, baseada na microbiologia, era tida como a chave fundamental para a resolução de todas as questões ligadas ao entendimento do universo vivo. Com a certeza nas possibilidades da experimentação aliada à profunda confiança na 'vitória' da ciência, as doenças ganharam uma designação de caráter provisório. Caberia à microbiologia fornecer os elementos da 'cura infalível' ou as soluções profiláticas para o bom termo das entidades mórbidas, através de soros curativos e vacinas imunizantes (Salomon-Bayet, 1986; Williams, 1992; Löwy, 1994).

Nessa ocasião, a idéia de progresso em tudo se aproximava da ciência: ela remetia ao progresso da própria ciência (ou seja, ao conhecimento puro); ao progresso graças à ciência (ao progresso técnico) e ao progresso por intermédio da difusão da ciência, com todas as suas desejáveis implicações sociais, morais, físicas e políticas. Por constituírem componentes essenciais da cultura do período, as idéias surgidas no campo da física, da matemática e da biologia, por exemplo, eram consideradas parte integrante da própria modernidade que então se consolidava, com seus saberes e cidades em constante renovação. Nessa época, 'ciência', 'modernidade' e 'progresso' suscitavam representações e imagens que se revezavam no imaginário europeu, e participavam, na verdade, de um mesmo campo semântico (Béguet, 1990; Prochasson \& Rasmussen, 1996; Marcellin Berthelot. 'Le rôle de la science dans le progrès des sociétés modernes', Revue Scientifique, n. 21, maio. 1897, p. 642).

No entanto, nem tão unânime, a suspeita de uma 'bancarrota' da ciência começava a rivalizar com o otimismo técnico-científico. ${ }^{6} \mathrm{Na}$ verdade, uma certa lassidão nascia em reação a um cientificismo exageradamente pretensioso e apressado em tudo resolver e explicar. A sensação geral na Europa da época era a de que as certezas da ciência, ao fim e ao cabo, não tinham em nada contribuído para melhorar os homens, umas máquinas funcionando segundo as leis da mecânica, da biologia e da geometria. Como nas palavras de Max Weber (2002: 38), "podemos dominar tudo por meio da previsão. Isso é o mesmo que despojar de magia o mundo." A propósito, pode-se mencionar também o sucesso da personagem de Mary Shelley, Frankenstein, suscitando desconfianças quanto às ambições de totalidade do conhecimento científico (Ferrone \& Rossi, 1994; Panza \& Pont, 1995; Hersant, 1995; Gemelli, 1997; Rossi, 1999). 
Na França, muitos defenderam uma reação a essas ameaças de desmantelamento dos fundamentos da ciência. Um dos seus nomes principais foi Henri Berr, com seu ideal de síntese do conhecimento e cuja divisa principal era: 'tudo compreender e tudo unir'. Importantes revistas científicas francesas, como a Revue du Mois e Scientia, aderiram ao seu projeto de unificação do saber. E se o relativo consenso em torno do ecletismo de Berr era uma resposta a essa má-consciência científica fin-de-siècle parecia constituir também uma atitude de resistência ao Affaire Dreyfus, tido, na ocasião, como um elemento a mais de divisão no mundo intelectual francês (Biard, Bourez \& Brian, 1997; Prochasson \& Rasmussen, 1996).

No entanto, ao lado desse projeto de Berr, novos espaços de sociabilidade e de produção intelectual eram criados na França, e na reforma universitária da Terceira República, de forte ascendência positivista, o privilégio na formação intelectual foi todo posto na laicização do ensino, na especialização do saber e na profissionalização dos alunos. Esse quadro era o triunfo tanto da reação ao 'conservadorismo cultural' das elites francesas mais tradicionais quanto do espírito positivo da Nouvelle Sorbonne, na qual, segundo Charles Péguy, avultavam os estudantes de ciências e seu desprezo pela cultura literária e humanista, tida como pedante, esnobe, verborrágica, apolítica, elitista, clerical, sem generosidade social e sem vida. A premissa maior dessa reforma era a de que não caberia à educação superior 'cultivar espíritos', mas criar consciências livres (Sirinelli, 1994; Cochart \& Haroche, 1989).

A reação propulsionada por Berr, transfigurada com o passar dos anos numa defesa da pluridisplinaridade, não conseguiu solucionar a crise na convicção de uma unidade essencial da ciência. Na mesma época, novas disciplinas nasciam procurando marcar suas fronteiras. Estavam, nesse período, a substituir uma visão de mundo baseada na ordem da natureza por outra fundada na ordem dos fenômenos naturais e sociais que exigiam, de sua parte, saberes com diferentes procedimentos e operações. Na primeira, os eventos ocorridos só eram inteligíveis quando localizados num esquema geral; na segunda, partia-se da premissa de que cada evento poderia, e deveria, ser compreendido em si mesmo (Biard, Bourez \& Brian, 1997; Sennett, 1999).

Os diferentes territórios da ciência iam sendo demarcados por intermédio de associações profissionais, de revistas especializadas e de congressos nacionais. Acrescente-se ainda a mais contundente marca do período: a 
convicção no crescimento ininterrupto dos saberes científicos, mas também a consciência da sua rápida obsolescência (Dhombres \& Dhombres, 1989). Conhecimentos seguiam se acumulando e se modificando em função de evolução e transitoriedade imanentes, percebia-se, à própria ciência (Marcellin Berthelot. 'Le rôle de la science dans les progrès des sociétés modernes', Revue Scientifique, n. 21, maio. 1897, p. 642). Todo esse debate implicou, por sua vez, uma reavaliação dos seus problemas filosóficos, precipitando o nascimento de uma nova epistemologia (Knight, 1986). Assim, ao passo em que as suas ambições cognitivas, universalistas e enciclopédicas se tornavam mais modestas, aumentavam as suspeitas de que subsistiriam facetas naturais e sociais desconhecidas dos cientistas e de que nem todo o mundo tinha-se tornado acessível ao seu olhar perscrutador. Como dar conta do que ainda não conheciam se já estavam convencidos de que não poderiam saber tudo?

\section{Especialização Científica e Congressos Internacionais}

Ocorre que essas dúvidas eram todas elas da ciência, não da técnica. Era uma crise das suas pretensões absolutizantes, mas não da sua vocação cognitiva e pedagógica. ${ }^{7}$ As concepções que relacionavam o conhecimento científico à esfera da utilidade, ou, em outros termos, à técnica, continuavam vigorando com força. Mais do que a aplicação prática das teorias científicas, a técnica era a própria 'ciência' congregando forças e agindo sobre as matérias-primas da natureza de modo a contentar as necessidades e os desejos dos homens. O que se passava a discutir era a importância da racionalização dos seus procedimentos. Abraçada à técnica, a ciência poderia continuar a crescer se soubesse aproveitar o seu único e mais confiável recurso de expansão: a inteligência dos homens. Para isso, seria preciso ordená-la de modo que não se perdesse em elucubrações variadas e inúteis. Tantas tinham sido as descobertas científicas e os conhecimentos produzidos no correr do século XIX que se temia uma exaustão do capital criativo dos indivíduos (Poincaré, 1904; Picon, 1994).

Mais moderados nas suas aspirações cognitivas, os cientistas passavam a reconhecer que a especialização era o 'preço' a pagar para o aprofundamento e progresso dos seus conhecimentos. Seria o meio mais adequado para acompanhar o aumento incessante da quantidade de saberes que redundavam em teorias e que, por sua vez, transformavam-se em descobertas. A ciência seguia se dividindo, e cada nova divisão acabava, de 
sua parte, constituindo uma disciplina particular exigindo esforços intelectuais inéditos.

Em 1895, no interior da Sociedade Britânica para o Progresso da Ciência, por exemplo, a fisiologia, a antropologia e a botânica já tinhamse despreendido por completo da rubrica abrangente 'biologia'. E essa fragmentação está longe de se reduzir a uma mera questão de nomenclatura, envolvendo preceitos de formação intelectual e atuação profissional. Desse modo, a especialização funcionava como um modo de 'economizar' e direcionar o trabalho científico, que não podia mais ser desperdiçado em estudos de teorias, questões e idéias de toda e qualquer sorte. Ao trabalho do pensamento deveria corresponder a eficácia da ação. Com isso, aumentava o estigma dos amadores e curiosos, que supostamente desperdiçavam suas energias intelectuais na dedicação a uma multiplicidade de saberes e longas diligências em descobertas e invenções, e das quais, inclusive, não comprovavam eficiência ou utilidade (Matagne, 1992).

Nesse caso, a profissionalização das pesquisas era condição fundamental para o reaparelhamento das aspirações intelectuais dos cientistas. Definitivamente, não havia mais lugar na comunidade letrada para os amadores das ciências, aqueles de quem se contava a piada de que "conheciam nada sobre tudo". ${ }^{8}$ Não se concebia mais uma atividade intelectual verdadeiramente produtiva fora das instituições científicas renomadas. E quem quisesse se dedicar e se deliciar com o perfil espetacular das descobertas científicas, que se satisfizessem como consumidores e espectadores ocasionais dos museus científicos e das revistas de vulgarização científica, cuja aparição só fazia aumentar naquelas paragens. Esse era o grande ideal da profissionalização científica que emergia naquela ocasião - nada mais de espontaneidade e gosto pessoal, ou desprendimento e isolamento intelectual (Cohen \& Drouin, 1989).

E a essas novas demandas, o ideal da especialização intelectual pareceu, portanto, servir a contento. Bastava que as explorações no domínio científico, levadas a cabo mundo afora por esses especialistas, reverberassem internacionalmente. Esses dois elementos da ciência do período - especialização e internacionalização - são inseparáveis. Não à toa, o fascínio pelas realizações e descobertas científicas ganhava ares de 'fenômeno mundial' (Roger, 1995). Não é preciso, quanto a isso, lembrar o enorme sucesso das célebres exposições universais que varriam a Europa nessa época, com destaque para a exposição universal de 1900, ocorrida em Pa- 
ris - nada menos que o centro irradiador dos valores da civilização. ${ }^{9}$ E essa exposição parecia valer especialmente por ter sido a mais bem-sucedida no esforço de reunir "as maravilhas, tesouros e as descobertas desconhecidas" de todos os povos da terra! $!^{10}$

Dada essa importância crescente do intercâmbio científico internacional, na mesma época, foi promovida, também em Paris, uma verdadeira maratona de congressos científicos internacionais. Durante cinco meses foram realizados no Palais des Congrès, no coração da exposição universal, reuniões e encontros de médicos, higienistas, sanitaristas, geógrafos, físicos, químicos, fotógrafos, zoólogos, astrônomos, aviadores, meteorologistas, educadores e inventores, que teriam trazido, de "todos os cantos do mundo", os novos frutos do seu trabalho (Pesce. 'De l'exploitation intensive de créations intellectuelles', Revue Scientifique, n. 17, out. 1900, p. 524; Revue Scientifique, n. 5, out. 1900, p. 129).

Charles Richet, célebre fisiologista francês, ganhador do prêmio Nobel de fisiologia em 1913 e editor da Revue Scientifique, escreveu na sua revista longo artigo em que relatava e defendia a importância desses congressos. Reconhecia que as idéias e as descobertas científicas brotavam antes no silêncio dos laboratórios que no meio de grandes assembléias. Mas insistia, só se refinariam por intermédio da troca de conhecimentos. E o interesse dos congressos internacionais era, exatamente, a aproximação dos cientistas de cada país, pois, do seu ponto de vista, poucos minutos de conversa com um experimentado sábio ensinavam muito mais do que horas e horas de leituras na solidão de uma biblioteca (Charles Richet. 'Les Congrès Internationaux de 1900', Revue Scientifique, n. 24, jun. 1900, p. 737). ${ }^{11}$

Para Richet, se alguma característica especial pudesse ser conferida à pesquisa científica daquele período, ninguém poderia duvidar de que era internacional, e não só isto, de que era, sobretudo, impessoal. O trabalho coletivo era o principal valor a nortear a organização daqueles congressos. O fisiologista advertia ainda que cientistas, estudiosos e diligentes, existiriam em todos os laboratórios, universidades e centros de pesquisa do mundo. E mais, com o tão alto e acelerado desenvolvimento dos conhecimentos, os cientistas não teriam mais a possibilidade de se dedicar a todas as disciplinas, abrangendo os resultados de todas as pesquisas feitas. A ciência tinha-se tornado profundamente especializada, e isso era para ele um dado irreversível. De que outro modo acompanhar o trabalho e as descobertas dos colegas, usando-as em proveito das próprias reflexões e 
incremento do saber científico, senão por intermédio da internacionalização das informações?

Assim, a esse sistema da assimetria e autonomia das disciplinas correspondeu, no mesmo passo, o ideal das redes internacionais. No mais, serviam também para os cientistas se autocelebrarem - certificavam que só teriam podido realizar encontros internacionais depois de terem inventado, eles próprios, as locomotivas, o telégrafo e os navios a vapor, permitindo-lhes rápida circulação e intenso intercâmbio (Charles Richet. 'Les Congrès Internationaux de 1900', Revue Scientifique, n. 24, jun. 1900, p. 738).

A rigor, os congressos científicos europeus começaram a se agigantar em 1822. Nessa época, encontros de sábios ganharam dimensões nacionais. E o primeiro deles deu-se naquele mesmo ano em Leipzig, reunindo uma série de naturalistas e físicos alemães. Mas, já na década de 1860, os congressos nacionais em toda a Europa passaram a contar sistematicamente com a presença de convidados estrangeiros, o que possibilitou a sua crescente nomeação como 'assembléias internacionais'. A cada encontro, o país organizador promovia o congresso e convidava os participantes estrangeiros de maior renome. E assim, nessas últimas décadas do século XIX, seguiam-se revezando pelas grandes capitais européias congressos de astronomia, medicina, história, antropologia, arqueologia, geografia e estatística. Em poucos anos, passaram a ser promovidos por coordenações que reuniam, concomitantemente, cientistas de vários países (Prochasson, 1989; Rasmussen, 1990).

Os congressos e, no limite, a própria especialização intelectual conformavam-se ao modelo naturalista então hegemônico. Segundo esse registro biologista, a humanidade era compreendida pela imagem ou metáfora do 'organismo', segundo a qual cada uma de suas frações tinha uma função a exercer. Defendendo uma ação recíproca de cada parte, ou de cada cientista em cada país, os defensores da internacionalização acreditavam, acima de tudo, na federação humana como um dos maiores resultados da ação e da evolução dos homens, e cuja marcha, é claro, já tinha sido iniciada. Confiavam caminhar para o aperfeiçoamento da humanidade. A representação modelar para a ciência da época era a de um empreendimento coletivo internacional envolvendo séries de pessoas e de variadas especialidades (Schlanger, 1971; Novicow. 'Les facteurs de la fédération humaine', Revue Scientifique, n. 7, ago. 1900, p. 304). 
E esse desfecho para o conhecimento científico era mesmo muito engenhoso, pois, até um século antes, ao menos aos espíritos enciclopédicos de Laplace, Lagrange ou Monge, era impossível conceber a dedicação a domínios exclusivos do saber. Mas, em fins do século XIX, a necessidade da especialização intelectual se tinha definitivamente imposto a muitos. Já certificavam a impossibilidade de um saber completo do globo.

Os jovens Marx e Engels, no seu famoso Manifesto Comunista, culpavam a divisão do trabalho 'imposta' pelo triunfo do capitalismo como a responsável pela mecanização e monotonia dos tempos modernos. Jacob Burckardt, no seu Civilization of the Renaissance in Italy, lançado em 1860, lamentava, em dolorida nostalgia, o fim do ideal do l'uomo universale, cujo extraordinário saber, dali em diante, só se poderia imaginar. E mesmo Goethe, em romance escrito na velhice, Die Entsagenden ou Os Renunciadores, ensinava, sem sombra de melancolia, que os homens do século XIX estavam a desistir das pretensões à universalidade do conhecimento, concluindo por fim que "limitar-se a um ofício é o melhor" (apud Gay, 1995: 475).

De Adam Smith, com o seu clássico setecentista Wealth of Nations a Émile Durkheim e De la Division du Travail Social no século XIX, o princípio da especialização rompeu as fronteiras das máquinas, manufaturas, indústrias, mercados e economia, passando a ser discutido, adotado e valorizado na formação educacional dos homens. Daí o crescente recuo do padrão aristocrático da educação clássica. Os novos tempos pareciam exigir administradores, engenheiros, cientistas, em suma, técnicos e especialistas, e não mais o cultivo harmonioso de todas as capacidades humanas, como da paidéía grega à bildung neo-humanista.

Some-se a esse incremento da divisão do trabalho intelectual, a multiplicação dos intermediários entre os intelectuais e suas obras, assim como as mudanças nos seus próprios métodos de trabalho graças a uma cada vez maior institucionalização das suas atividades. O efeito de 'vitrine' ganho pelo conhecimento científico naquelas décadas parece especialmente ilustrativo da sua nova imagem pública: saber tanto mágico quanto hiperracional, totalmente inacessível aos homens comuns (Béguet, 1990). De fato, um cenário assim traçado apresentava muitas novidades.

O imperativo da troca de informações entroncou-se a outro tema então debatido com a máxima urgência e importância nos congressos internacionais: a obrigatoriedade da padronização internacional da nomenclatura científica. Crescia a convicção de que as generalizações, símbolos, 
conceitos, em suma, de que o ajustamento da linguagem científica seria um modo de economizar as energias mentais dos cientistas, simplificando-lhes o exercício de criar novas idéias (Rasmussen, 1995).

Nessas reformulações epistemológicas, nota-se a proeminência de Henri Poincaré, um dos primeiros a salientar o papel ativo dos cientistas na formulação das hipóteses como antecedentes da pesquisa empírica. E ao defender a elaboração de hipóteses como pré-condições indispensáveis sem as quais nenhuma experiência poderia ser executada, o autor, dentre outros, redefiniu as próprias relações entre o objeto e o sujeito do conhecimento (Poincaré, 1904, 1968). Em outras palavras, ele questionava o procedimento científico calcado exclusivamente na observação para sinalizar a importância do experimento e, sobretudo, do experimentador como condições fundamentais para a produção de verdades. Até o século XIX, a objetividade consistia na pressuposição de que havia respostas sem perguntas e resultados independentes de um ser formulador de questões (Arendt, 1992; Pomian, 1999). No novo cenário da virada do século XX, impunhase o exame dos procedimentos e das condições de elaboração das pesquisas científicas (Panza \& Pont, 1995; Gattinara, 1998a, 1998b).

No entanto, receoso dos 'excessos subjetivistas' que, no seu entender, poderiam acometer o conhecimento, Poincaré (1904) insistia que um fato científico não deveria ser entendido como de autoria individual do pesquisador. Contra esse risco, ofereceu uma visão bastante particular da objetividade científica. Na sua proposta, os conceitos deveriam ser a principal medida de generalização da ciência. ${ }^{12}$ Dito de outro modo, ciência e 'fixidez discursiva' seriam sinônimos, e a padronização conceitual passaria a constituir a sua mais importante operação objetivante. De acordo com Poincaré, as generalizações e as classificações só poderiam ser levadas a bom termo se estabelecida uma linguagem convencional, comum aos cientistas de todo o mundo. Ademais, ao obedecer a regras fixas, a escrita científica maximizava as possibilidades de transmissão das informações, minimizando, no mesmo sentido, os erros.

$\mathrm{Na}$ conjunção de todos esses fatores, consolida-se a idéia da ciência como uma rede de disciplinas especializadas. Ou melhor ainda, como um sistema de relações entre fenômenos independentes, cabendo aos cientistas, especializados em cada ordem desses fenômenos, estabelecer as suas inter-relações. E como firmar ligações entre resultados de pesquisas e, sobretudo, difundir a padronização dos conceitos e nomenclaturas entre cientistas isolados uns dos outros por idiomas e países? 
Os congressos, associações e encontros científicos internacionais não se fariam, por muitos anos, sem contemplar as 'idiossincrasias' da linguagem empregada pelos cientistas. Segundo o conceito do período, habilitar-se em ciência significava 'aprender uma linguagem técnica específica'. Com a proliferação dos cursos universitários na Europa, notadamente na França e na Inglaterra, esse aspecto da especialização tornou-se ainda mais proeminente, uma vez que, aprendendo uma dada teoria específica, seus praticantes aperfeiçoavam-se no emprego do seu jargão disciplinar, contribuindo ainda mais para distanciar físicos de químicos, e de biólogos, e de geólogos, e assim por diante (Knight, 1986).

Se disciplinas especializadas em objetos específicos exigiam expressões particulares, a linguagem padronizada, por sua vez, dava aos cientistas as chances de retomarem os trabalhos dos colegas, fiando os resultados das suas pesquisas e experiências. Regras discursivas e conceitos fixos funcionavam, assim, como um modo de fazer circular teorias em espaços onde eram igualmente conhecidas e aplicadas, ajudando a constituir e a fortalecer comunidades de especialistas (Wallenborn, 1990). Novos fenômenos e novas descobertas exigiam novos nomes e novas terminologias que só poderiam ser comunicadas a outros cientistas num sistema de códigos partilhado por uma comunidade de profissionais. Assim definida, a especialização científica tornou-se indissociável de cânones discursivos e conceituais.

\section{Ciência e Literatura}

O esoterismo da atividade científica correspondeu em igual intensidade à sua cada vez maior profissionalização. Era próprio da ciência do período constituir meios especializados, fabricar diferenças, estabelecer hierarquias, impor distinções. E tamanhas delimitações tornavam-se cada vez mais finas. Daí chegarmos, no mesmo passo, às discussões sobre as possíveis diferenças entre dois pontos de vista no domínio das atividades intelectuais - o sentimental e o utilitário (Saussure. 'Le point de vue scientifique', Revue Scientifique, n. 2, jan. 1901). Divisões que se desdobraram, por sua vez, em rígidas separações: de um lado, entre as práticas científicas e os estudos pretensamente animados pela mera intenção de conhecer; de outro, entre a ciência e as atividades artísticas e literárias.

Vale assinalar que todos esses questionamentos, por vezes díspares entre si, deram-se em conjunto, sem grandes desavenças temporais e no 
mesmo movimento de renovação epistemológica da ciência, discutido nas páginas anteriores. Não há também como deixar de reconhecer que, com o incremento dos estudos em fisiologia e, sobretudo, com a adoção do método antiapriorístico de Taine, as diferenças entre as 'sensações' e as 'idéias' começaram a funcionar também como fortes recursos de argumentação quando o objetivo era o de garantir as 'especiais' competências das reflexões levadas a cabo pelos cientistas (Revue Scientifique, n. 2, jan. 1900, p. 34-44; Rolland 'La critique scientifique', Revue Scientifique, n. 3, jan. 1901, p. 69-78).

Estudos médicos em fisiologia nervosa e cerebral vinham sendo realizados sistematicamente na Europa desde o século XVIII, num grande esforço em secularizar a cognição humana, entendida, desde muito, como a mais notável expressão da inclusão dos homens nos desígnios de Deus. Alimentados pelo enigma do dualismo mente-corpo, esses estudos foram classificando e patologizando as fragilidades nervosas, cujas suscetibilidades pareciam atingir preferencialmente as mulheres e os espíritos artísticos sensíveis. "Moradas do prazer e da dor", os nervos foram, em todo esse período, associados à imaginação, à insanidade, à histeria, ao erotismo e ao amor (Rousseau, 1993). E essas mesmas teorias médicas extrapolaram os tratados psicológicos da época, invadindo a literatura e mesmo toda a cultura européia do período. Estudos sobre os nervos passaram a fornecer modelos e normas para o comportamento humano. A partir deles, recrudesceu-se, no século XIX, o senso do controle do 'eu'. Em outras palavras, desenvolveu-se a crença de que o perfil psicológico de uma pessoa poderia transparecer não só na sua personalidade, mas na sua aparência física e na sua postura social, e tudo isso involuntariamente. De onde, o imperativo do autocontrole ou do retraimento, já que pessoas muito impulsivas e expressivas eram consideradas potencialmente insanas. Essas pesquisas médicas, preocupadas com as origens das emoções humanas, levaram também à conclusão de que sentimentos seriam reações físicas inatas e não afetos a desenvolver a partir do cultivo do espírito, de leituras, viagens, pensamentos elevados ou arte refinada. Os sentimentos humanos, portanto, se explicariam e se expressariam, fundamentalmente, por intermédio de fenômenos físicos (Sennett, 1999).

Nesse sentido, as manifestações artísticas, a imaginação, a memória, a curiosidade, o gênio, a paixão e a criatividade, do ponto de vista dessa fisiologia, passaram a ser interpretadas como expressões involuntárias e descontroladas de sentimentos, e que, uma vez não cana- 
lizadas, poderiam levar tanto à loucura quanto ao crime. No mesmo passo, o apaziguamento, o refinamento e a cortesia eram signos de força psicológica, constituindo comportamentos e posturas sumamente valorizadas. Eram apanágio do gênero masculino, duro, forte, agressivo, cerebral e conciso, em oposição à feminilidade, suave, imaginosa, indefinida, vasta e fraca. Corpo e destino social interligavam-se nessas décadas (Williams, 1976; Trautmann, 1981; Barker, 1984; Morton, 1984; Clarke \& Jacyna, 1987; Rousseau, 1993).

A imaginação e a sensibilidade foram imediatamente associadas ao gênio e à paixão, prestando-se assim às atividades de cunho estético. Ser nervoso, delicado, melancólico, disperso, carente, sensível, angustiado e deprimido era, literariamente, muito romântico (Rousseau, 1993). No que se refere à fisiologia cerebral, os estudos médicos sustentavam que a 'imaginação' seria um fenômeno mental menos elaborado que o raciocínio, o que imediatamente já determinaria a maior 'complexidade física' de um homem de ciências em comparação aos demais colegas dos ofícios literários e artísticos. A ele seriam especialmente requisitados, por exemplo, grande capacidade de observação, fleuma e desprendimento para abandonar preconceitos e superstições no encontro com os resultados das suas pesquisas. Isto sem contar que, como de certa forma alheados do domínio dos sentimentos, aos cientistas caberia a responsabilidade pelo lado utilitário da vida, comandando com seu método e instrução a organização social (Rolland. 'La critique scientifique', Revue Scientifique, n. 3, jan. 1901, p. 78).

No limite, ao conhecimento científico correspondiam a aridez e a sisudez na apresentação das idéias, e isto, contra o fardo da erudição inútil que só mesmo os 'medíocres' carregariam com prazer (Lepenies, 1996). Além do mais, polir frases refinadamente seria uma perda de tempo para um autêntico cientista - bastava-lhe o domínio de uma terminologia específica. Enquanto isso, do ponto de vista da própria literatura, tornava-se clara a missão do literato como a de encantar e embelezar a realidade com sentimentos. Mesmo a sua imagem fazia referência ao homem culto e diletante de amável trato. No que se refere aos encargos científicos, não mais escrever bem era, tão simplesmente, o preço pago pelo progresso de toda a humanidade (Charle, 1979; Goulemot, 1992).

Nesse desdobramento, também na Europa, a escrita literária foi sendo definida por suas pretensas palavras sonoras e cansativas dissertações; o contrário, por sua vez, da escrita científica, caracterizada por uma prosa 
dura porque oriunda do chamado 'espírito da certeza'. Em suma, textos científicos deveriam ser escritos de modo a eliminar os elementos de 'retórica', tidos como inapropriados a convicções baseadas em resultados de pesquisas exteriores ao discurso. ${ }^{13}$ No mais, era considerada totalmente 'ilusória' porque contrária aos fatos, anacrônica e incompatível com o movimento do mundo - qual poderia ser o valor de estudar grego ou latim, 'línguas mortas', em lugar da dedicação às ciências, que, ao fim, fariam mesmo o mundo funcionar ? $?^{14}$

E esse quadro era uma convulsão na história das idéias européias, marcada, ainda no período, pelos embates entre a 'fria razão', de um lado, e a 'cultura dos sentimentos', de outro, entre o Ancien Régime e a modernidade (ou entre les classiques e les modernes), entre a restauração e a revolução, entre a Ilustração e a Contra-Ilustração, entre a formação humanista versus a especialização, entre o liberalismo aristocrático e o pedagogismo radical dos positivistas (Mayer, 1987; Lepenies, 1996; Pomian, 1999).

Como já se discutiu, até o século XVIII reinava o ideal enciclopédico, não sendo sequer concebida uma separação nítida entre literatura e ciência. ${ }^{15}$ Para o homem letrado o importante era, basicamente, saber escrever bem, ter estilo distinguível formalmente. Buffon é o caso paradigmático do homem de ciência cujo valor como escritor impressionava até mesmo Baudelaire! Aliás, exemplo que demonstra, de forma contundente, esse processo de separação entre a ciência e a literatura, levado a termo definitivamente no século XIX - Buffon foi o último letrado a basear sua reputação científica no talento literário, e o primeiro a perder prestígio como cientista por ser demasiadamente literato e pouco pesquisador (Lepenies, 1996).

Na Europa, os valores então definidos como 'literários' já estavam totalmente discriminados dos procedimentos entendidos como próprios ao domínio científico, como pesquisar, explicar, descrever, testemunhar, provar, indiciar, registrar, avaliar, estimar e conferir observações. ${ }^{16}$

Com efeito, mais do que uma profissão, a ciência representava uma 'visão de mundo', um 'paradigma' para todas as outras formas de manifestação intelectual. E sem demora, essa reputação se ancorou entre as elites letradas do Brasil, assim como reverberaram entre elas as repercussões sobre a internacionalização dos cânones científicos. Tal como antecipou Santos Dumont em Paris, os cientistas brasileiros passearam muito à vontade nesse debate. 


\section{Notas}

1 "A época atual constitui um desses momentos críticos em que o pensamento humano sofre transformações. Dois fatores fundamentais acarretaram essas mudanças. O primeiro deles, a destruição das crenças religiosas, políticas e sociais de onde nasceram todos os elementos da nossa civilização. O segundo, a criação de inéditas condições de existência e de pensamento, estimuladas pelas modernas descobertas das ciências e da indústria. E como as idéias do passado, mesmo comprometidas, ainda são muito fortes, e as que deveriam lhes substituir estão ainda em formação, a época moderna não passa de um período de transição e de anarquia" (Tradução livre).

2 A relação entre o aviador e a cidade de Paris era de mútuo encantamento. Nela, estudou química, física, mecânica e eletricidade, sempre mostrando-se reconhecido ao postular que naquela capital 'repousaria o futuro do mundo'. Paris, de sua parte, curvava-se às suas crescentes descobertas. Até àquela data, Santos Dumont já tinha realizado breve vôo, em 1897, num balão. Em julho de 1898, empreendeu um vôo mais demorado em outro balão feito de seda japonesa. Em setembro do mesmo ano, realizou um vôo num dirigível com um motor movido à gasolina. Em 1899, construiu um hangar, o primeiro de que se teve notícia no mundo, para voar num balão em que se sentava na sela de uma bicicleta. E esse vôo acabou sendo realizado, com enorme sucesso, em agosto de 1900 durante a realização da Exposição Universal, então sediada na cidade, juntamente com o Congresso Internacional de Aeronáutica.

3 Sabemos que Dumont não chegou a tanto, mas, ainda sim, em 23 de outubro de 1906, voou pelos céus de Paris com o 14-Bis, no primeiro vôo realmente mecânico da história.

4 O próprio Berthelot assegurava que estavam aptos a criações muito melhores que as da natureza (apud Gusdorf, 1974).

5 Para Gusdorf (1974), essa redução do campo mental foi o fator decisivo da inflexão epistemológica ocorrida no século XIX: a associação (pejorativa) da filosofia à metafísica e a total independência da ciência frente à filosofia.

6 A imagem é de Célestin Bouglé ('La banqueroute de la science et la morale solidariste', Revue du Mois, n. 1, 1906, p. 441).

7 Tanto é verdade que o século XIX destituiu de loas todos aqueles pensadores que viram com reservas a ciência e a técnica. Dentre estes, podemos citar Nietzsche, Kierkegaard e Burckhardt, por exemplo. Sobre esses intelectuais, ver Lepenies (1992).

8 Na verdade, naqueles tempos de transição, a piada se completava fazendo menção também ao especialista, que, de sua parte, conheceria "tudo sobre nada" (Béguet, 1990: 20).

9 A cidade de Paris gozou de notabilidade como centro científico internacional em toda a segunda metade do século XIX. Quanto a isso, basta lembrar que foi sede horsconcours das exposições universais de 1855, 1867, 1889 e 1900.

10 Paris Exposition (1900, p. 171). A propósito, consultar também Exposition Universelle de 1900: séjours à Paris pendant l'exposition de 1900 (1900).

${ }^{11}$ Pode-se também assinalar que uma das grandes mudanças ocorridas no período, auge da crise da cultura humanista e, logo, da emergência da especialização científica, 
foi também a perda de legitimidade que o 'ensinar' sofreu frente ao 'aprender'. Nesses agrupamentos científicos especializados, o foco era todo ele direcionado para a formação de profissionais capacitados a serem, antes de mais nada, pesquisadores (Knight, 1986; Prochasson, 1989).

12 Gattinara (1998a) chega mesmo a sugerir a importância dos textos de Poincaré para a consolidação da revolução einsteiniana que se seguiria na física, posto que suas teorias sobre a importância das hipóteses no conhecimento científico problematizaram igualmente as relações tempo/espaço e teoria/experiência.

13 Essa compatibilidade 'intrínseca' entre linguagem, realidade e verdade era tão indissociável da ciência do período que toda a crítica de Nietzsche à arrogância cognitiva dos homens concentrava-se nesse postulado. No seu dizer, se linguagem e coisas fossem mesmo tão essencialmente conciliáveis não existiriam tantos idiomas diferentes no mundo. Essa discussão na obra do filósofo alemão, sobretudo no seu texto 'Sobre a verdade e a mentira no sentido extra-moral', foi especialmente ressaltada por Ginzburg (2002).

${ }_{14}$ Quanto ao tema, podem-se consultar, por exemplo, os seguintes artigos das revistas científicas do período: De Monzie ('Pédagogie'. La Science au XXe Siècle, n. 51, mar. 1907, p. 86), Goubin ('Vieilles choses', La Revue du XXe Siècle, n. 7, jul. 1903, p. 249) e Félix Le Dantec ('Les caractères dans l'hérédité', Revue Scientifique, n. 2, jan. 1900, p. 33).

15 Vincenzo Ferrone (1997) destaca que na Itália setecentista o homem de ciência já era reconhecido como um tipo social totalmente diferente do letrado. Era o investigador dos fenômenos naturais com seus métodos empíricos, medições e verificações experimentais.

16 Essa distinção ficou conhecida nas ciências sociais das últimas décadas como a da separação entre 'duas culturas'. Debate em que a noção de 'cultura' foi utilizada no seu sentido antropológico. Desse ponto de vista, cada métier possuiria o seu respectivo quadro de referências a informar atitudes, modos de comportamento e de compreensão totalmente inconciliáveis (Snow, 1968). As propostas apresentadas por Grenier, Grignon e Menger (2001) são mais matizadas por não 'encarcerarem' os literatos e cientistas em pólos tão antagônicos. Ver também Cochart e Haroche (1989). 



\section{A crítica da Razño Pomposa}

o homem de ciência não é aquele que sabe, mas o que a todo momento é capaz de saber. Essa capacidade só se adquire por um exercício muito prolongado, feito especialmente nas faculdades de ciências, nos laboratórios ou nos institutos onde se fazem as pesquisas. Miguel Ozório de Almeida (1931)

Como afirmou João Cruz Costa em estudo anterior sobre a inteligência brasileira da virada do século $\mathrm{XX}$, "o que é de admirar é a rapidez com que estava informada do que se passava na Europa" (1967: 280). Essa intelectualidade foi contemporânea e integrou as repercussões do darwinismo, da microbiologia e da revolução tecnológica, e adotou as idéias de 'ciência', 'progresso' e 'civilização' por considerá-las marcas nítidas e confiáveis de conformidade profunda com o Velho Continente.

Esse alinhamento com o imaginário ocidental era totalmente coerente com a própria conjuntura intelectual da ocasião, que, como vimos, começava a estimular e a exigir as trocas internacionais. Não surpreende, portanto, que participassem com avidez desse debate, incorporando-lhe as diretrizes básicas. ${ }^{1}$

Sucede que esse ideário científico, ou, nas palavras do próprio Costa, essa 'idolatria pela ciência', somado ao positivismo e à defesa da formação especializante da Terceira República Francesa, chegou ao Brasil já nas últimas décadas do século XIX. A original combinação dessas idéias e escolas científicas, nas suas novas filiações, justaposições e interferências teóricas, aumentava, nos intelectuais, as expectativas de ação social e política, pela aplicação da ciência na agricultura, na indústria, enfim, na modernização do país. Tudo isso os levava tanto a criticar o nacionalismo romântico, as 
instituições monárquicas e a escravidão - do seu ponto de vista, sintomas do atraso - quanto também a crer e a defender uma reforma radical do ensino oficial no Brasil segundo as pautas da 'lei da diferenciação' formulada por Herbert Spencer. Essa lei não era nada mais do que a própria representação rebarbativa da idéia de progresso, segundo a qual o tema da função de um indivíduo casava-se com o imperativo do seu aperfeiçoamento num campo específico de atuação (Costa, 1967; Barros, 1986; Carvalho, 1990).

Nesse desdobramento, essa formação imprimia nos intelectuais uma forte confiança nas soluções apresentadas pela ciência, assim como os nutria de aversão à ostentação de títulos e privilégios individuais que ultrapassassem a precedência do 'bem coletivo' na vida pública. O positivismo, especialmente e pela sua associação entre ciências naturais e teorias de mudança social com ordem política, operava como uma aura de cientificidade para a atividade que exerciam (Dantes, 1996; Ferreira, 1989). Funcional e ordeiro, nada poderia ser pior nesse esquema que a 'divagação das inteligências' ou a 'anarquia intelectual'. O bom direcionamento da educação era a própria base da ordem social (Heilbron, 1991; Petit, 1994).

Além de Comte e Spencer, Taine, Haeckel e Renan faziam também muito boa figura no debate de idéias que tomou a intelectualidade da época. A orientação intelectual proposta por esses autores resumia-se à predominância da razão sobre os sentimentos e a uma defesa apaixonada da adoção do método científico de estudos em toda e qualquer atividade intelectual (Costa, 1989). E é o que se dá: o recrudescimento da confiança na ciência para instaurar o progresso no Brasil. Expande-se com isso a idéia de que o saber precisaria ser útil, do ponto de vista do progresso material do país, e nunca deleitável. E nos primórdios do processo de modernização e urbanização que tomou a Capital Federal nos primeiros anos do século XX, a ciência foi considerada a principal fiadora dessa renovação da paisagem, graças à atuação dos seus maiores representantes, os engenheiros e os médicos.

\section{Idéias Desconhecem Fronteiras ${ }^{2}$}

Ocorre que todo esse ideário, em conjunto e nos seus diferentes arranjos, estimulou a diversificação das atividades nos espaços de exercício científico já existentes. Em fins do século XIX, nas escolas de medicina e de engenharia, mais particularmente, começaram a brotar críticas à 'cul- 
tura livresca', que, pretensamente, sacrificava o ensino prático. A Escola Politécnica, por exemplo, sofreu uma reforma em 1890: aboliu os cursos de ciências físicas, matemáticas e naturais, e passou a formar, exclusivamente, engenheiros (Coelho, 1999; Ferreira, 1989). O Museu Nacional (MN), de sua parte, era um estabelecimento dedicado à coleção, preservação e exibição de objetos, mas onde começavam a se desenvolver estudos experimentais em ciências naturais, incluídas a zoologia, a botânica e a antropologia física. Um laboratório de fisiologia foi criado na casa em 1880. Aliás, o Museu era a instituição que mais se transformava sob a direção de Ladislau Neto (1876-1893), abandonando o seu perfil de cabinet de merveilles ou de mera exposição de 'coisas' ao deleite público (Schwarcz, 1993; Lopes, 1997).

No mais, desde a década de 1880, nas faculdades de medicina do Rio e da Bahia, os médicos, tais como os seus congêneres europeus, começavam a aderir à microbiologia preconizada por Pasteur. Segundo a concepção médica do período, a emergência das pesquisas bacteriológicas levaria ao progressivo abandono do paradigma climático-telúrico. Seguindo essa climatologia médica, o diagnóstico e a terapêutica exigiam a identificação tanto de agentes ambientais - climáticos e geográficos (miasmas, pressão atmosférica, calor, umidade, parasitas, gases químicos e temperatura) quanto de hábitos sociais 'anti-higiênicos' (desde banhos frios a bebidas alcóolicas, por exemplo). Para tanto, seriam necessários longos estudos em higiene, profilaxia, química, física, fisiologia, anatomoclínica, meteorologia, botânica, climatologia, topografia e geologia (Edler, 1999).

Tamanhas leituras na medicina passaram, gradativamente, a ser identificadas como um saber exageradamente abstrato pelas novas gerações que iam sendo entronizadas sob as idéias de Pasteur. ${ }^{3}$ A dependência estrita que estabelecia, para a definição das relações entre sintomas e moléstias, entre indução lógica, conhecimento médico e observação das condições ambientais e dos costumes tornava essa medicina excessivamente contigente e opinativa do ponto de vista dos novos grupos. Contra uma terapêutica que se reduziria a meios sociais e a climas específicos, os pastorianos apresentavam uma etiologia única, os micróbios; marca de uma teoria que foi, crescentemente, sendo considerada mais 'verdadeira' e mais 'científica' (Léonard, 1983; Edler, 2001).

Com a introdução da medicina pastoriana, parte dos médicos dedicou-se ao estudo dos microorganismos causadores das doenças infecciosas, animais e humanas. Houve, assim, certo incremento na construção de laboratórios nas faculdades, seguida de perto da obrigatoriedade das 
provas práticas, da extinção das sabatinas, dos pontos e dos compêndios de literatura estrangeira. O currículo foi diversificado e novas cadeiras foram criadas pelo decreto n. 7.247 na Reforma Leôncio de Carvalho de 1879. Novas especialidades clínicas limitadas a patologias e a áreas do organismo surgiram, deslocando, lentamente, a prática médica do leito do doente para o laboratório (Edler, 2001). Tudo isso passava a redefinir o estoque de conhecimentos exigido: os profissionais deveriam se dedicar a um número específico de fenômenos, utilizando-se de novas aparelhagens como os microscópios, estufas, termômetros, reativos químicos, instrumentos de vidro como empolas e pipetas; o que, de sua parte, exigia treinamento especial. Esses médicos, que se esforçavam em dedicar-se aos estudos experimentais nos laboratórios de análises químicas e bacteriológicas, tentavam fazer deles a sua opção profissional fora do exercício da clínica e do ensino (Benchimol, 1999; Ferreira, Fonseca \& Edler, 2001).

Parte dos médicos insistia, pois, na sua formação experimental, no seu distanciamento tanto em relação aos que chamavam de 'charlatães' (todos os curandeiros, práticos, benzedeiros, herbalistas, barbeiros sangradores, espíritas, boticários, homeopatas e até mesmo médicos estrangeiros cujos diplomas não tinham sido validados no país) quanto ao que identificavam como ecletismo e empiricismo indutivo da 'arte médica'. Mas também na visibilidade social das ciências, tal como ocorria na Europa, e de onde adviria, acreditavam, o seu alto padrão de civilização. Lecionavam ciências físicas e naturais e trabalhavam em clínicas privadas, hospitais beneficentes ou de isolamento, e em instituições públicas como higienistas. Os mais renomados integravam a Academia Nacional de Medicina (ANM), o grande centro de excelência do debate científico no Império (Benchimol, 1999; Edler, 1999; Sampaio, 2001; Figueiredo, 2002). ${ }^{4}$

E a Academia de Medicina tanto abrigava os preceitos climáticotelúricos quanto via surgir, acatava e debatia as novas idéias bacteriológicas, uma vez que incorporava os novos profissionais que adquiriam renome em outras instituições num pacto mútuo de venerabilidade (Edler, 1999). Esse foi o caso de Carlos Chagas, cientista do Instituto Oswaldo Cruz (IOC), admitido instantaneamente em 1910, logo após a descoberta da moléstia que levaria o seu nome em 1909 (Anais da Academia de Medicina do Rio de Janeiro, jan.-dez. 1910 [1913]).

Na Academia, os métodos experimentais eram vistos, por muitos médicos, como conflitantes com a própria tradição da instituição tida como 
excessivamente 'sábia', ou seja, 'teórica', reunindo profissionais que teriam sido formados por longos estudos e nenhuma prática experimental. Vista, à época, como um dos locus de um paradigma científico decadente, testemunhou as controvérsias que procuravam alinhar, modelar e organizar os conflitos vividos pelos 'homens de ciência'. Nos resumos e atas de suas reuniões, publicados nos seus anais e boletins, pode-se acompanhar o calor dos debates que os inquietavam - notadamente a oposição entre, de um lado, o chamado 'academicismo teórico'; de outro, 'o espírito prático' (Anais da Academia de Medicina do Rio de Janeiro, jul.1903-jun.1904, [1905], p. 5-16).

Acrescente-se ainda que, em julho de 1900, foi criado o Instituto Soroterápico Federal, que ganharia definitivamente o nome de Instituto Oswaldo Cruz (IOC) em 1908. O 'laboratório de Manguinhos', como era então conhecido, tinha a incumbência inicial de produzir soro para o combate à peste bubônica, identificada, em 1899, no porto de Santos, e que já começava, naquela ocasião, a ameaçar a Capital Federal. O cientista que deu nome à instituição assumiu a sua direção em dezembro de 1902. Oswaldo Cruz ganhou a fama de 'cientista notável' por ter confirmado os corretos diagnósticos de Adolfo Lutz e de Vital Brazil, que enxergaram microorganismos por trás das epidemias tanto do cólera, que grassava no Vale do Paraíba em 1894, quanto da peste de Santos, além de ter sido, ele próprio, muito eficaz na campanha contra a febre amarela no Rio de Janeiro. No mais, conseguiu verbas públicas para construir suntuoso castelo mourisco que só redobraria o simbolismo da grandeza dos seus feitos (Brito, 1995). Já em 1903, a casa passou a organizar cursos especializantes e de natureza experimental, promovendo o ensino de bacteriologia, parasitologia, zoologia médica, anatomia e histologia patológica. Dedicados a estudantes de medicina e a profissionais formados, esses cursos de aplicação, como eram então chamados, foram criados à semelhança dos que já eram oferecidos no Institut Pasteur de Paris e na Alemanha. Além de prever a sistematização do estudo científico especializado, os cursos visavam preparar os profissionais brasileiros de modo habilitá-los a discutir questões científicas e a publicar suas pesquisas em periódicos de circulação internacional. Outros cursos de educação superior eram então oferecidos pelo IOC, como os de matemática aplicada e os de biologia geral. Em todos esses casos, a intenção era a de associar pesquisa original ao ensino superior e exclusivo de ciências (Fonseca Filho, 1974; Benchimol, 1990, 1999). 
Essas instituições discutidas nas últimas páginas criaram também as suas primeiras revistas científicas, como os Arquivos do Museu Nacional (1876) e as Memórias do Instituto Oswaldo Cruz (1909). Esses periódicos divulgavam as investigações realizadas pelos brasileiros e as notícias estrangeiras de maior interesse científico; eram distribuídos gratuitamente em bibliotecas, escolas profissionais de medicina, veterinária e agricultura, sendo ainda objeto de intercâmbio com outros periódicos nacionais e estrangeiros. Além dessas publicações, as instituições estimulavam a organização de concursos públicos, de exposições nacionais e a participação de seus membros em eventos internacionais.

Os membros dessas instituições integravam, assim, desde as duas últimas décadas do século XIX, congressos internacionais de medicina e ciências, como, por exemplo, o Congresso de Medicina de Copenhague, em 1884, o IX Congresso Médico Internacional nos Estados Unidos, em 1887, o I Congresso Médico Pan-Americano de Washington, em 1891, o II Congresso Científico Latino-Americano de Montevidéu, em 1901, o II Congresso Médico Latino-Americano de Buenos Aires, em 1904, e o XV Congresso Internacional de Medicina de Lisboa, em 1906. Neles, discutiam a adoção de novos critérios de cientificidade, atentando para a urbanização, modernização e intercâmbio entre indústria e ciência nos países europeus que visitavam, como, sobretudo, a França, a Inglaterra e a Alemanha. E, isso tudo, além de estarem se associando, no papel de membros correspondentes, a sociedades científicas internacionais como a Sociedade de Ciências de Lisboa, a Sociedade de Higiene de Paris e a Sociedade Médica Argentina, dentre outras (Lopes, 1997; Benchimol, 1999).

Tamanha mobilização, "tendência que acentua(va) a comunhão universal", pode ser também aferida pela incidência dos congressos que iam sendo organizados aqui mesmo no Rio de Janeiro, como, por exemplo, o Pan-Americano, de 1905 (Souza Pitanga. 'Os eleitos', Renascença, n. 38, abr. 1907, p. 155).

Em 6 de agosto daquele ano, realizou-se a sessão de abertura do Terceiro Congresso Científico Latino-Americano no Teatro São Pedro de Alcântara. Num cenário "caprichosamente ornamentado e iluminado à luz elétrica" reuniram-se os "delegados do pensamento dos povos em prol da ciência, da paz e da felicidade de cada uma das nações" (Freitas, 1906: 153-154). Entre as instituições brasileiras orgulhosamente integradas ao encontro, a ANM, o Clube de Engenharia, o Clube Militar, a Escola Politécnica, a Faculdade de 
Medicina, a Faculdade Livre de Direito, a Faculdade Livre de Ciências Jurídicas e Sociais, o Instituto Histórico e Geográfico Brasileiro (IHGB), o MN e a Sociedade de Medicina e Cirurgia. Nenhuma delas deixou de enviar seus representantes. Olegário Herculano (IHGB), Abreu Fialho (ANM), Afrânio Peixoto (ANM), Álvaro Alberto da Silva (Sociedade de Medicina), Otto de Alencar (Escola Politécnica), Miguel Couto (Faculdade de Medicina e ANM), Louis Cruls (Observatório Astronômico e Escola Militar), Orville Derby (Comissão Geográfica e Geológica de São Paulo), Fernandes Figueira (Hospital Nacional dos Alienados), Laudelino Freire (Colégio Militar), Barão Homem de Mello (Colégio Militar), Herman von Ihering (Museu Paulista), João Batista de Lacerda (MN), Juliano Moreira (ANM e Hospital Nacional dos Alienados), Henrique Morize (Escola Politécnica, Observatório Astronômico e Clube de Engenharia), Luiz do Nascimento Gurgel (Sociedade de Medicina e Cirurgia), Paula Freitas (Escola Politécnica), Rocha Faria (Faculdade de Medicina e ANM), Rocha Lima (Instituto Soroterápico Federal), Carlos Seidl (ANM), Souza Lima (ANM) e Souza Pitanga (Sociedade de Geografia e IHGB) teriam deixado o silêncio dos seus laboratórios e gabinetes de trabalho para dar notícia da sua produção científica aos congêneres americanos. Em nome da vibração internacionalizante que se propagava pelo mundo inteiro, aderiam à aproximação entre os centros latino-americanos de atividade científica e ajudavam a fazer da ciência o "encadeamento em movimento geral da inteligência humana" (Freitas, 1906: 157-159).

Na mesma ocasião, os participantes estrangeiros foram estimulados a conhecer a cidade, em visitas oficiais a pontos e instituições que reforçassem a reputação científica e a modernização do país. Sendo assim, conheceram o MN, o Observatório Astronômico, a Repartição Geral dos Telégrafos, o Corpo de Bombeiros, o prédio do Supremo Tribunal Federal e percorreram a Avenida Central. Foram ainda ao Instituto de Higiene, à Faculdade de Medicina, ao Instituto Vacínico Municipal, à ANM, ao Jardim Botânico, à Escola Politécnica, às obras do porto e do canal do Mangue, às oficinas da Estrada de Ferro Central do Brasil, à Escola Nacional de Belas Artes, à Biblioteca Nacional, à Sociedade Nacional de Agricultura, além de terem realizado excursões de confraternização a Petrópolis, ao Corcovado e à Floresta da Tijuca. ${ }^{5}$

E se o maior objetivo dos congressos era o da equiparação mundial do progresso científico alcançado pela Europa, um dos temas mais can- 
dentes nos seus debates e comunicações era a padronização das línguas portuguesa e espanhola com a terminologia científica internacional (Freitas, 1906: 169). Nos relatórios do Congresso Científico de 1905, nota-se que algumas dissertações e comunicações em diferentes áreas do conhecimento - como matemática, ciências físicas, ciências naturais, engenharia, medicina e cirurgia, medicina pública, antropologia, ciências jurídicas e sociais, pedagogia, agronomia e zootecnia - propuseram discussões visando à uniformização da nomenclatura científica, tal como já estariam fazendo, por intermédio de encontros internacionais, a França, a Alemanha e a Inglaterra. ${ }^{6}$

Segundo os membros do congresso, no caso brasileiro, a pertinência da internacionalização dos cânones científicos seria redobrada. Além de 'ignorados e atrasados' em ciência, os descendentes dos portugueses, em especial, pareciam mais 'naturalmente' inclinados à produção literária. Naquele universo de significados semânticos justapostos entre 'literatura', 'humanidades' e 'retórica', os textos médico-científicos brasileiros, parecia-lhes lógico, só poderiam apresentar-se em estilo verboso e empolado. Se, como conotavam à época, o papel da linguagem era o de comunicar pensamentos, uma escrita que não fosse exata e concisa seria totalmente ignorada num meio em que a troca das idéias era obrigatória. E, na sua visão, como se não bastassem as diferenças de mentalidades e de idiomas entre os povos, o que já lhes dificultava a comunicação, a retórica por meio da qual os brasileiros se expressavam era tão amaneirada e exótica que só contribuiria, ainda mais, para isolar e descarrilar a participação do país na linha geral da evolução humana (Freitas, 1906: 469-474).

Essas preocupações em debater as relações entre especialização e linguagem científica constituíam um cruzamento entre uma tendência que acompanhavam nos livros, revistas e congressos internacionais e a incorporação de um preceito científico tornado habitual com o incremento das pesquisas experimentais - os cientistas seguiam tomando consciência de que selecionavam e preparavam eles mesmos o material a ser observado no microscópio. De onde a convicção de que do laboratório só sairiam respostas a perguntas e hipóteses elaboradas anteriormente por eles mesmos. A percepção desse caráter ativo da pesquisa científica redobrou as suas preocupações objetivantes, assim como justificou as insistentes referências à originalidade das suas incursões científicas. Trabalhando sob os mesmos padrões, quem desenvolvesse preceitos inéditos ou descobrisse 
novos fenômenos só poderia dar conta do seu 'gênio especial' e do avanço científico do seu país de origem. Inclinação teórica que, naqueles primeiros anos do século XX, se concentrou na internacionalização da formalização dos conceitos, protocolos e modelos de linguagem científica. No Brasil, a associação entre especialização e linguagem não foi diferente.

$\mathrm{Na}$ verdade, essa tendência especializante começou a ser adotada na década de 1890 nas faculdades de medicina e nos cursos de aplicação em que se formaram esses homens de ciência, cada vez mais dedicados a atividades institucionais e mais ciosos da intransponibilidade da sua cidadela. Como participavam, com cada vez maior freqüência, de encontros internacionais, onde apresentavam, aos colegas e pares, os resultados de suas pesquisas, e publicavam, com a autoridade de especialistas, o fruto dos seus trabalhos, surpreendia-lhes o duelo direto de argumentos, feito em vias não especializadas. O confronto direto supunha o uso da 'retóri$\mathrm{ca}^{\prime}$, a sedução lingüística para o convencimento e, o pior, a contenda entre desiguais: leigos, de um lado, e homens de ciência, de outro. E é por isso que, de forma recalcitrante, mas progressiva, saíram dos jornais as polêmicas e os debates sobre preceitos científicos e reputações intelectuais para adentrarem as preocupações educativas da vulgarização científica. E enquanto a linguagem da notícia e da entrevista tomou os jornais diários, os textos técnicos, com forte recurso à representação visual, se concentraram nos periódicos e nas suas seções especializadas.

Grande parte das revistas que circulava no Rio de Janeiro, já nos primeiros anos do século XX, dedicava seções especiais nas suas páginas de modo a dar voz e a noticiar os feitos - científicos e institucionais desses profissionais que seguiam se especializando. Interessava contar com a colaboração de todos os que estavam 'engrandecendo' o conhecimento do Brasil, de sua gente e de sua natureza. Acompanhando as publicações, pode-se notar que se subdividiam em letras, ciências e artes. No entanto, com o passar dos anos, as seções de ciência vão-se adensando frente às de letras, sendo que algumas revistas, inclusive, abandonam a exclusiva alcunha de 'literárias' para se chamarem também ou tão-somente 'científicas', como foi o caso de $A$ Época e de Século $X X$. Suas subdivisões vão-se diversificando e tornando-se cada vez mais finas, e as seções de ciência passam a abrigar temas em história, sociologia e etnografia, assim como biografias, estudos sobre a população brasileira, educação, costumes, tradições, aspectos da terra, saúde pública, expedições científicas, discussões 
sobre psiquiatria, neurologia e psicologia, textos sobre a aplicabilidade de importantes teorias (físicas e biológicas), resenhas e notas sobre publicações de livros científicos, nacionais e estrangeiros (notadamente franceses, alemães e americanos), participação de instituições e de homens de ciência brasileiros em encontros internacionais, e artigos discutindo as especificidades da linguagem e da mentalidade científicas. ${ }^{7}$

Dentre os periódicos pesquisados, pode-se mencionar que a Revista Americana (1909-1919) privilegiava temas como as viagens científicas, as relações da ciência com a técnica, os feitos do MN e do IOC, a classificação das ciências, as associações científicas do Brasil e as relações da ciência com a filosofia. A revista A Época (1906-1920) debatia a classificação das ciências, a importância da sociologia, Le Play e a ciência social no Brasil, as obras de Sílvio Romero, Euclides da Cunha e Alberto Torres; também dava notícias sobre a Faculdade de Medicina e o IHGB. A Século XX (19051906) trazia uma seção intitulada 'notas científicas' na qual tinham acolhida especial os assuntos biomédicos e temas referentes à linguagem científica. A Ciência e Educação (1929-1930) priorizava o problema universitário brasileiro, a formação de profissionais em ciências, a pesquisa e o ensino prático, o cinema e as ciências naturais. A Revista do Brasil (1917-1927) discutia, nas suas seções de ciência, higiene e saneamento, a criação de universidades no Brasil, casos de plágio intelectual, resenhas de livros científicos, linguagem científica, história natural, medicina, fisiologia, notícias de instituições, como o IOC e o MN, e de congressos, traduções de textos científicos, ensino, o sertão e a natureza nos românticos, expedições científicas, psicologia, psiquiatria e teoria da relatividade. A Braziléa (1917-1918) reunia textos sobre flora brasileira, política e temas sociais, linguagem científica e psicologia. A Brasil Acadêmico (1910), além de publicar uma seção de ciências, na qual discutia biologia, matemática, psicologia, história natural, medicina, ensino científico e fisiologia, trazia ainda a seção 'panteão científico', com foto e biografia de grandes nomes nacionais a começar por Oswaldo Cruz. A Ciências e Letras (1912-1918) também concentrava textos numa seção de ciências destinada a discutir medicina experimental, instrução pública, a teoria evolucionista e pedagogia em ensino prático. A Renascença (1904-1908) costumava dar notícias de congressos científicos e das atividades de instituições brasileiras, como a Faculdade de Medicina, o MN, o IOC e a ANM. 
Em comparação aos textos das seções de literatura e arte, que traziam reproduções de romances, poesias, pinturas, esculturas e críticas literárias, os artigos científicos tinham notas bibliográficas, nas quais os autores explicitavam as obras mencionadas e a autoria das idéias de que faziam uso, assim como ainda citações no original. Traziam também desenhos, gráficos, equações matemáticas e, nos textos médicos, pungentes fotografias de doentes.

Os textos publicados nas revistas de ciências e letras, os discursos feitos na ANM, as conferências educativas, os artigos, entrevistas e perfis publicados nos jornais, que comentamos nas últimas páginas, são corpus documentais e suportes textuais totalmente distintos, mas que constituíam, ao fim, um só palco onde os homens de ciência da virada do século XIX para o XX apresentavam-se como 'cientistas', ou seja, como os profissionais de um ramo específico do saber. Nele também apresentaram as suas novas vestes, brancas e acéticas, e entoaram, em uníssono, as suas falas de ruptura e especialização. Convergentes, esses homens de ciência asseguravam que não descendiam do passado ibérico. E, para enfrentá-lo, empreenderam vigoroso combate contra a retórica, sinônimo de espiritualismo, de teoricismo, de literatura romântica, de enciclopedismo e de excesso palavreador. Todo um debate indissociável das mudanças que pleiteavam na natureza do próprio trabalho científico no Brasil. Demandas que seguiram de par, nas décadas de 1910, 1920 e 1930, com a fundação da Academia Brasileira de Ciências (ABC) em 1916 - onde se reuniram, aliás, como os 'profissionais da ciência' - e, posteriormente, com a fundação da Associação Brasileira de Educação (ABE) em 1924, com o lançamento do Manifesto dos Pioneiros da Educação Nova em 1932 e com a consolidação das universidades no Rio de Janeiro e em São Paulo, de modo a 'ensinar ciência' formando novos especialistas, pesquisadores e técnicos.

Graças a esse panorama que montaram ao fundo das instituições que diversificaram ou que ajudaram a criar, fortaleceu-se, no meio letrado do período, a percepção de que as supostas prestidigitações provocadas por uma linguagem ornamentada e enciclopédica eram (também) alguns dos maiores males do Brasil.

\section{A Ciência como Profissão}

Os debates sobre padronização da linguagem científica e especialização intelectual encontram uma via de acesso imediato nos textos de 
cunho 'histórico' de alguns homens de ciência dessa geração. Salientando as precariedades anteriores a essa discussão e insistindo em falar do alto do seu 'ineditismo' como pesquisadores brasileiros, sua intenção nesses artigos era a de traçar toda a história da atividade intelectual no Brasil, com destaque para o século XIX, época de esparsas, mas, na sua visão, significativas mudanças no panorama institucional do país.

Pode-se começar citando um extenso texto de Roquette-Pinto, diretor do MN, de título "Ciência e cientistas do Brasil". ${ }^{8}$ Na sua argumentação, a contumaz insipiência dos centros de pesquisa e ensino científicos brasileiros, dos seus museus, bibliotecas e laboratórios, teria como origem direta a predominância da "cultura clássica, gramatical e literária" que vicejava em Portugal, chegada aos brasileiros (ou brasilianos, como preferia dizer) na forma de uma robusta tradição de pensamento toda ela entremeada de retórica.

Nas palavras do diretor do MN, até o século XIX, teria reinado, no país, uma 'indigência mental' quase absoluta, em função da escassez total de 'casas de pensamento'. Como afirmou, somente com a criação das faculdades de medicina do Rio e da Bahia, como também do Observatório Astronômico e do próprio MN, "berço real das ciências físicas e naturais neste país", teria sido possível o planejamento sistemático de atividades originais no âmbito científico. Essas instituições, a seu ver, foram iniciativas notáveis, embora tenha salientado, ainda assim, que aqueles homens "fizessem ciência sem saber", tal como o personagem de Molière, Monsieur Jourdain, que falava em prosa sem se dar conta. E nem poderia ser de outro modo, pois, de acordo com Roquette-Pinto, a predominância do "ambiente social retórico" do século XIX acabava numa mão estimulando a produção literária, e na outra impedindo o pleno desenvolvimento da cultura científica no Brasil. ${ }^{9}$

Em texto do mesmo tom e proposta, Juliano Moreira, diretor do Hospício Nacional dos Alienados e membro titular da ANM, pretendeu traçar um panorama do 'progresso das ciências no Brasil', evidenciando sua intenção de demonstrar ao público a total falta de razão daqueles que defendiam a pretensa inépcia natural dos brasileiros para os estudos científicos. De acordo com o autor, a dificuldade para realizar pesquisas no país foi fruto da ampla influência do colonizador português sobre os brasileiros, com seu gosto especial pela 'cultura do espírito' em detrimento dos assuntos racionais. 
Para Moreira, a colonização portuguesa teria sido mesmo um mal, mas, certificava, em pouquíssimo tempo de vida independente, os brasileiros, no gozo da sua maioridade, já tinham conseguido ampliar e desenvolver estudos em geologia, história natural, etnografia, ciências aplicadas, e na "medicina científica moderna", como chamou, pela fundação dos "laboratórios de pesquisa original", como o de Manguinhos, ou o montado na casa dos irmãos Álvaro e Miguel Ozório de Almeida. E todos esses esforços - ou nas suas palavras, "esta soma de trabalho útil" - só foram efetivamente válidos por terem ecoado internacionalmente, e por terem incluído a ciência brasileira no nível do século, ou, melhor ainda, "na história da civilização humana". Afinal, segundo ele, os trabalhos brasileiros estavam, pela primeira vez, sendo sistematicamente citados nas revistas européias ('Progresso das ciências no Brasil', Almanaque Garnier, 1914, p. $181-198) .{ }^{10}$

Como vimos, ao conotar a cultura herdada de Portugal não só como decadente, mas como a própria antinomia do trabalho intelectual que levavam a termo, esses homens de ciência a definiam, sem muitos discernimentos de sentido, como 'literária', 'livresca', 'romântica' e 'retórica'. Todos esses elementos eram empregados como sinônimos para indicar todos os opostos da atividade que realizavam e que tinham, como insistem, inaugurado no Brasil. Tudo isso redundava na qualificação da sua produção como 'internacional', 'científica', 'original' e 'moderna', encaminhando-os ainda a uma discussão sobre as suas 'linguagem' e 'mentalidade'. Além de funcionarem como um modo de atender às demandas da comunidade científica internacional, 'língua' e 'psicologia' científicas pareciam constituir o próprio cerne da sua progressiva autonomização como grupo profissional no interior do meio letrado brasileiro.

Assegurar que aquela 'nova geração' era 'científica' ao contrário das anteriores, não significava somente valorizar-lhes os métodos práticos e experimentais. Os homens de ciência que se formaram e atuaram na virada do século XIX para o XX percebiam-se como os primeiros a contribuírem para a fixação definitiva de instituições, padrões de análise e normas de conduta social para a ciência brasileira. A novidade que se auto-atribuíam tão insistentemente resumia-se, na verdade, a uma freqüente reação à amplitude dos temas e enormes círculos de pessoas a freqüentar a sua seara. No seu desenho, mantido o modelo tradicional, arriscavam-se a fazer ciência como uma atividade cultural múltipla, sem campos de atuação específicos, pretendendo 
ora abranger a universalidade dos objetos, ora ornar o espírito (Miguel Ozório de Almeida. 'A nossa estação de alta cultura', O Globo, jun. 1929 - Arquivo Pessoal Miguel Ozório de Almeida. Centro de Memória/ABL).

Entre eles, já se começava a assentar a convicção de que textos científicos só tinham valor quando publicados por escrito e em suportes imparciais e especializados. Por conta disso, as revistas vão-se organizando segundo as suas contribuições, e vão ganhando, assim, seções de divulgação dos resultados das pesquisas científicas e da sua validação no exterior; enquanto os jornais, antes vetores e canais de resolução de controvérsias, vão-se tornando instrumentos de vulgarização científica.

No mesmo sentido, conferências e discursos pareciam a esses homens de ciência de uma enorme informalidade quando o caso era firmar novas teorias ou fazer circular o resultado de experimentações. Como pretender apresentar provas definitivas, que, aliás, no seu universo mental precisavam ser visíveis, só com o uso das palavras? Sugerem, por exemplo, o quanto seria absurdo imaginar Oswaldo Cruz exibindo-se para um público leigo, num púlpito, como um poderoso orador, pretendendo encantar sua platéia através de melódicos e flamejantes argumentos, e ainda defendendo, persuadindo e convencendo diretamente a população carioca da importância da vacina obrigatória. ${ }^{11}$ No mais, também eles partilhavam a convicção de que a exposição pública de saberes, sem objetivos educacionais, não passava de indício de diletantismo, exibicionismo e vaidade intelectual. Como os mais lídimos representantes da 'cultura das especialidades', esses homens de ciência se esforçavam em criar condições institucionais para o exercício de suas competências específicas, e isso para que os intelectuais brasileiros deixassem de ser conhecidos por suas variadas e múltiplas capacidades. O que, na verdade, acreditavam, fazia com que fossem considerados nomes possíveis tanto para qualquer grande serviço quanto para qualquer pequena pasta (Juliano Moreira. 'Progresso das ciências no Brasil', Almanaque Garnier, 1914).

Do ponto de vista desses homens de ciência, a exuberante cultura geral da geração anterior em nada mais combinaria com as restritas preferências intelectuais da geração educada numa República e sem as divisões sociais dos tempos da escravidão. ${ }^{12}$ No seu entender, sobretudo no correr do século XIX, um torto aristocratismo social teria estabelecido, entre os moços brasileiros bem nascidos e bem criados, que todo trabalho prático era aviltante, devendo ser rejeitado com desdém em favor das carreiras 
letradas e intelectualizadas. E exatamente dessa fidalguia, cujo correlativo lógico mais imediato na sua fórmula era a aquisição de uma vasta e múltipla instrução, diziam não padecer ('Roquette-Pinto', Vamos ler!, 23/03/1939, p. 45 - Arquivo Pessoal Edgard Roquette-Pinto. Centro de Memória/ABL).

Nos seus termos, entre os 'cientistas especializados' e os 'sábios diletantes de outrora', existiriam critérios profissionais que demarcavam diferenças inconciliáveis: a formação específica, o reconhecimento do mérito pelo trabalho desenvolvido, a socialização (já que os últimos se autoeducariam isoladamente e os primeiros seriam membros de equipes de trabalho homogêneas) e o acesso a materiais, instrumentos e equipamentos de pesquisa cada vez mais complexos. Por tudo isso, inclusive, os aspirantes à especialização intelectual não poderiam supor que alguém estudasse "ciência por estudar, simplesmente pelo prazer de se haver erudito". Na atividade científica, usariam de reduzida cultura intelectual, pois dependeriam muito mais da inteligência e da técnica. Receavam, inclusive, serem mal vistos como 'práticos' se possuíssem bibliotecas enormes ou vasta cultura. Quem manejasse "tamanha teoria, lendo por tantos livros" corria mesmo o risco de não parecer um hábil cientista, mesmo entre os colegas de profissão. ${ }^{13}$

Ilustrativa metáfora para a especialização intelectual que defendiam, foi-nos dada mais uma vez pelo atuante Roquette-Pinto, que a comparou à clausura dos conventos, "recanto apartado, onde os profanos não penetram pela proibição rigorosa das ordens, que vedam a entrada aos que não se prepararam para aquele ingresso" ('Notas de ciência', Revista do Brasil, n. 31, jul. 1918, p. 317). Para ele, a especialização científica funcionaria rigorosamente da mesma maneira, restritiva e inviolável. Os altíssimos níveis a que o conhecimento científico tinha chegado impediriam os leigos de espreitarem ramos que exigiam cada vez maiores aptidão e meneio. $\mathrm{O}$ recurso à imagem de um respeito sagrado pelos limites da ciência remetenos de pronto à importância que as diferenças entre as disciplinas iam adquirindo, na ocasião, entre os ditos 'cientistas modernos'. No seu dizer, somente aos 'sábios românticos', nos seus estertores, repugnaria a limitação ao estudo de uma só ciência (Miguel Ozório de Almeida. 'A seleção humana', Revista do Brasil, n. 57, set.-dez. 1920, p. 3).

É importante observar também a relação que estabeleciam entre 'facilidade de raciocínio' e linguagem padronizada. À semelhança dos congêneres europeus, defendiam que a linguagem dos cientistas era toda ela especial, posto que um só símbolo gráfico ou conceito serviria para 
substituir "longas frases do estilo literário". A simbolização do raciocínio conferiria à ciência não só uma forte autonomização intelectual, como ainda uma elasticidade do pensamento e uma otimização do capital criativo nunca vistas, sobretudo, no Brasil. Era, no entender dessa geração de homens de ciência, a própria independência da ciência frente à linguagem literária, dominante na vida intelectual do país por séculos. Por acreditarem que o cérebro humano tem uma capacidade limitada de produção intelectual, defendiam a divisão da ciência em ramos particulares do conhecimento. Quantidades menores de informações a reter e a utilizar aumentariam, na mesma proporção, a velocidade com que as idéias brotam na inteligência e se expressam por meio da escrita. E toda essa rapidez só seria efetivamente produtiva quando longas elucubrações fossem substituídas por categorias e símbolos específicos e bem definidos. O que defendiam, na verdade, era a expansão desse modelo discursivo para todas as disciplinas científicas, sendo que tanto mais exclusiva a linguagem de uma ciência especial, quanto mais precisa e importante seria no âmbito do conhecimento científico. E essa padronização da linguagem entre os homens de ciência brasileiros era fundamental para que rompessem, aos olhos dos pares estrangeiros, com a imagem da ciência brasileira como uma imensa Torre de Babel, assunto de estetas impressionistas ocupados com a beleza e singularidade da escrita (Luiz Betim Paes Leme. 'Notas científicas', Século XX, n. 1, out. 1905, p. 54).

Nesse sentido, era fundamental, no esquema desses homens de ciência, a aproximação entre especialização intelectual e linguagem científica. Tinham a total clareza de que o progresso dos conhecimentos científicos redundava em descobertas de novos fenômenos - de onde surgiria a necessidade da criação de novos termos, de forma a designar-lhes a existência e a facilitar-lhes a compreensão (Frederico Carlos Hoehne. 'A necessidade de uma flora brasileira', Revista Braziléa, n. 1, 1917, p. 5-10). Essa percepção da especificidade dos termos científicos encaminhava-lhes diretamente para a defesa da padronização da linguagem, se não mesmo para a sua modelização no próprio Rio de Janeiro, onde "a nomenclatura anda(va) os trambolhões na boca dos cientistas" (Roquette-Pinto. 'Notas de ciência: tecnologia científica', Revista do Brasil, n. 29, maio 1918, p. 70-72). Ou seja, onde as mesmas palavras, escritas com diversas grafias, acabavam servindo para designar eventos diferentes, ou onde os mesmos fenômenos eram designados por termos distintos, entre profissionais tão próximos, como, por exemplo, os da Faculdade de Medicina e os da Escola Politécnica. 
Em texto sobre o assumto, Roquette-Pinto sugere que os homens de ciência de cada uma dessas instituições estavam empregando uma verdadeira 'gíria', tal como os "sportmen" da cidade e seu "palavreado incompreensível". Para tanto, propunha a criação de um dicionário brasileiro no qual pudessem reunir os termos constituintes da prática científica, nacional e internacional (Roquette-Pinto. 'Notas de ciência: tecnologia científica', Revista do Brasil, n. 29, maio 1918, p. 70-72). E o tema era tão fundamental que, já cedo, em 1903, a ANM nomeou uma comissão composta pelos drs. Miguel Pereira, Juliano Moreira e Fernandes Figueira com o fim especial de rever, reformular e padronizar o vocabulário médico-científico brasileiro (Anais da Academia de Medicina do Rio de Janeiro, jul. 1903- jun. 1904, [1905]).

Mas toda essa discussão não pode ser circunscrita somente ao uso de símbolos e conceitos padronizados. A preocupação com a especificidade da linguagem científica já deveria ser considerada nos cursos de formação, onde os estudantes seriam ensinados a experimentar, a observar, a interpretar, e só então a compor suas narrações sobre o visto e o acontecido durante as suas experiências. A codificação conceitual supunha e exigia o ensino específico. Nesses termos, a linguagem científica nada mais seria do que "a expressão exata da realidade" e a "fiel manifestação do pensamento" dos cientistas (Arthur Neiva. 'Notas de ciência', Revista do Brasil, mar. 1921, p. 209).

Nesse esquema, como se vê, a escrita tinha uma importância vital, posto que veículo das pesquisas científicas. Nele, o 'estilo' se reduzia e se confundia com o 'sentido da realidade'. Em outras palavras, a escrita científica deveria repousar sobre um duplo postulado: verdade e transparência. Seu corolário era a realidade, ou melhor, a sistematização das variedades da realidade sob hipóteses e teorias fixas. Por isso, a necessidade de uma linguagem que fosse como um 'quadro de vidro', já que com a pretensão de ser tão perfeitamente transparente que as imagens ali relacionadas pudessem passear, sem contradições, entre a escrita e a realidade. Quanto mais não seja, o texto científico não primaria por recursos estilísticos por pretender mostrar uma realidade além de si mesmo.

No entender desses homens de ciência, essa linguagem era totalmente distinta da escrita literária. Os textos científicos deveriam ter, por exemplo, notas bibliográficas em abundância e breves comentários sobre as obras dos autores mencionados, assim como citações no original das fontes e matrizes teóricas que utilizavam. Na defesa da especificidade da linguagem científica, percebiam que produziam conhecimentos para a cir- 
culação estrita entre os pares. Por isso, a importância do domínio de uma terminologia esotérica, regular e abstrata (Miguel Ozório de Almeida. 'A seleção humana', Revista do Brasil, set.-dez. 1920, n. 57, p. 4).

Mais claros e mais simples ainda seriam os seus textos de vulgarização e popularização científicas. Esses homens de ciência tinham a total clareza dos matizes dos seus públicos; seus destinatários determinavam a composição formal dos seus textos. Ademais, estavam convencidos de que a linguagem empregada funcionaria, na verdade, como um prolongamento do comportamento pessoal. Os que empregam um palavreado pomposo seriam, segundo eles, umas pessoas vazias, artificiais, falsas, esnobes, desocupadas, egoístas e superficiais. Os de linguagem simples e clara, poderiam, de sua parte, ser caracterizados pela imperiosa necessidade de propagar idéias, de disseminar nobres juízos, de espalhar noções e valores que auxiliassem os seus semelhantes, facilitando, em suma, a rápida circulação dos preceitos de uma cultura superior. Pode-se com isso dizer que, por intermédio da linguagem, um indivíduo se definiria aos olhos dos outros, revelando seu senso estético, sua visão de mundo, suas preocupações ou desprezo pelos demais, sua formação intelectual, assim como sua capacidade de análise e raciocínio (Américo Bruschini. 'A importância da linguagem', Revista do Brasil, n. 80, ago. 1922, p. 391-392).

Saliente-se também nessa discussão sobre forma lingüística, a importância da sua associação ao que chamavam de 'mentalidade científica'. Importante na formação intelectual dessa geração, a teoria naturalista de versão positivista explicava os fenômenos sociais e os componentes psicológicos de um povo tributando na conta da formação histórica os seus elementos constitutivos, de onde a recorrente equação 'herança colonial portuguesa + mentalidade retórica = linguagem empolada' (Santos, 1978; Dantes, 1996; Despy-Meyer \& Devriese, 1999). Nesse seu esquema, portanto, desenvolver a ciência no Brasil só faria sentido instituindo-se uma mudança histórica de rumo, com o auxílio das modernas aparelhagens técnicas de que poderiam fazer uso e que, acabavam, ao fim, amoldandoos segundo novas visões de mundo. E tudo isso só se efetivaria se essa intenção fosse revestida de um duro combate contra o 'exclusivo talento' dos brasileiros, porque herdeiros dos portugueses, para fazer literatura. E voltavam-se especialmente contra a retórica, ou contra o "preciosismo literário, traduzido pelo emprego constante de arcaísmos e de formas caídas em desuso, o que torna(ria) a leitura de muitos escritos brasileiros em 
extremo difícil" (Miguel Ozório de Almeida. 'A ciência e a língua portuguesa', Revista do Brasil, n. 94, out. 1923, p. 150).

Na condenação insistente à retórica, nenhuma novidade, pois, precipitada pelo chamado 'espírito moderno' de que eram, eles próprios, os baluartes, tornou-se mesmo a tônica geral da produção intelectual brasileira nas primeiras décadas do século XX. Censurar a 'arte de bem falar' equivalia, na sua argumentação, a rejeitar o passado, ou seja, a ascendência portuguesa sobre a história do Brasil, refletindo no mesmo movimento a sua intenção de filiação a novas tradições de pensamento, como a alemã, a americana e, sobretudo, a francesa, de Pasteur e Poincaré (Henrique Morize. 'Pesquisas científicas na indústria', Revista da Sociedade Brasileira de Ciências, n. 3, 1919, p. 240-241; Henrique Morize. 'O movimento científico e industrial nos Estados Unidos', Revista da Sociedade Brasileira de Ciências, n. 3, 1919, p. 255; Amoroso Costa. 'A filosofia matemática de Poincaré, Revista de Ciências, n. 5, 1921, p. 106-111). Além de prover a língua científica do período, da França, mais especialmente, chegavam os principais modelos institucionais e livros científicos (Dantes, 1996).

Antes da ascendência dessas novas vertentes, de Vieira a Rui Barbosa, os intelectuais brasileiros "lusitaram", ou seja, se teriam restringido a uma linguagem clássica e castiça, revelando na verdade todo o estilo ibérico de falar e escrever (Afrânio Peixoto. 'Por protesto e adoração', A Época, ago. 1919 , p. 22). Assim configurada, e tão ancorada nessa já mais do que 'ultrapassada' tradição mental, a produção intelectual em língua portuguesa seria o próprio "túmulo do pensamento". Não causaria surpresa, portanto, a recorrente insipidez científica do país, já que a própria língua, pensada, falada e escrita, estorvava o raciocínio produtivo (Miguel Ozório de Almeida. 'A ciência e a língua portuguesa', Revista do Brasil, n. 94, out. 1923, p. 151)!

Outro dado importante e que precisa ser mencionado é que, na argumentação geral desses homens de ciência, o proverbial palanfrório dos intelectuais brasileiros era estimulado pela exagerada idealização da natureza. E se, segundo eles, uma desproporcionada listagem das exuberâncias naturais do Brasil tinha sido patrocinada pela literatura, com sua linguagem povoada de hipérboles e exageros, objetavam, de sua parte, que a natureza nada tinha de unidade cósmica e que nem dela eram parte integrante. Constituía tão-somente um objeto de conhecimento, no máximo uma paisagem a ser civilizada e transformada (Roquette-Pinto. 'Etnografia sertaneja', Revista Americana, jul. 1918, p. 151). 
Que a natureza tenha sido considerada um dos pomos dessa discórdia explica-se pelo cultivo da sua exuberância, no Brasil do século XIX, tanto na história natural quanto na literatura (Süssekind, 1990; Lopes, 1996; Kury, 1998, 2001; Freitas, 2002). Nas obras dos naturalistas-viajantes, como Spix, Martius, Saint-Hilaire, Hartt e Agassiz; dos literatos-historiadoresetnógrafos românticos, como Antonio Gonçalves Dias e Manoel de Araújo Porto-Alegre, bem como ainda na ficção científica de Augusto Emílio Zaluar lançada em 1875, O Doutor Benignus, ${ }^{14}$ por exemplo, partilhava-se o tópos do encantamento com as maravilhas e peculiaridades da natureza tropical. E no universo romântico, onde as singularidades naturais deveriam ser exaltadas e catalogadas, o sentido da intransmissibilidade da consciência intelectual em nada se coadunava com os imperativos da estabilidade, da padronização discursiva e da reprodutibilidade das experiências apregoadas pelo discurso científico pretendente à especialização. Na verdade, trata-se aqui de uma tensão entre uma visão de mundo marcada pelas idéias de fixidez e deslumbramento e outra a ser mediada pela transformação quase 'mágica' infligida pela adoção da técnica.

Como exigência do método científico, seria preciso estudar o que se procura modificar, e não, como faria a literatura, apagar e esconder da realidade toda a feiúra. E por isso, para utilizar as palavras de RoquettePinto, por serem 'pesquisadores', começaram a descrer das tão decantadas "riquezas fabulosas do Brasil" para fiar-se nas "decisivas possibilidades de trabalho". Estariam por demais cansados da longeva ladainha e do vão orgulho proporcionado pela crença no "nosso céu tem mais estrelas". E exatamente por serem 'cientistas modernos' "puseram-se a contar as estrelas". Se ouviam que "nossos bosques têm mais vida", organizavam expedições científicas para verificar a veracidade de tão ambiciosas teses; valendo a metáfora iconoclasta por ilustrar o trabalho científico tanto como o desvelador da inutilidade dos adornos estéticos quanto como o examinador das verdades. Terminantemente, não aceitavam mais, no seu dizer, que o Brasil continuasse a ser tema de lirismo, subjetivismo poético e sentimentalismo (Vamos Ler, 23 mar. 1939, p. 45 - Arquivo Pessoal Roquette-Pinto. Centro de Memória/ABL).

\section{Divergências no Espelho}

Uma das tendências recentes nos estudos de história das ciências concentra-se na análise da linguagem científica como a da 'retórica da 
transparência' (Shapin \& Shaffer, 1993; Sigrist, 2001). Para o período estudado, no qual o discurso científico tendia a estabilizar a sua linguagem, toda essa discussão tem grande pertinência. Diversas análises salientam que as principais estratégias de 'convencimento' das 'verdades' do texto científico regulam-se pela mobilização de elementos que dão a impressão de que esse tipo de discurso 'fala sozinho' (Genthilhomme, 1984; Peytard, 1984; Jacobi, 1984, 1999; Cassen, 1990; Gardin, 1991; Lévy-Leblond, 1996; Licoppe, 1996; Sigrist, 2001). Dentre essas características, podemse citar a ilustração das informações (longe do seu aparente e secundário estatuto de redundância em relação ao discurso, seu papel é o de redobrar a idéia de que a análise científica se ocupa de objetos empíricos), a explicitação dos instrumentos e da metodologia utilizados, a utilização de formas verbais plurais e passivas graças às quais a pesquisa pareça efetuar-se sem protagonistas muito individualizados (como a recorrência constante do emprego do verbo na primeira pessoa do plural), e, não por acaso, o uso obrigatório de terminologias fixas. E estas últimas, por possuírem definições estáveis do ponto de vista das relações de equivalência que pretendem estabelecer entre o léxico e as referências externas ao discurso, se prestam, mais especialmente, ao papel de emudecer as vozes dos seus autores.

Os modelos de linguagem e as formas verbais empregadas no discurso científico, mensagem estática, pretendem-se transparentes e neutros por serem conotados como instrumentos de intermediação entre o sujeito conhecedor e o seu objeto. Nesses termos, o conteúdo do discurso científico, por ser tomado como um duplo da realidade, é 'tudo', enquanto a forma verbal encarregada meramente de transportá-la da abordagem ao resultado é 'nada' (Lévy-Leblond, 1996).

Nessa representação que emergia no período, assenta-se a convicção de que 'argumentos', por pressuporem uma manipulação da linguagem e por extrapolarem a 'realidade' à qual se faz referência, não convencem os pares, tendo, inclusive, o poder de enganá-los. Os homens de ciência que vimos discutindo passavam a concordar quanto à existência de uma 'verdade científica' estabelecida pelo consenso quanto aos instrumentos pelos quais se alcança um resultado. A anuência geral e a regularidade dos modelos de linguagem passavam a ser considerados a maior 'prova' da verdade do que se diz. E tudo isso, de modo a deixar os colegas em condições de julgar a pertinência dos recursos empregados, de controlar mutuamente seus produtos finais, de atestar a validade dos saberes constituídos e, sobretudo, de recompor, ainda que mentalmente, o percurso das pesquisas (Sigrist, 2001). 
Movimento de generalização contínua e de monologia axiológica, as representações da credibilidade do discurso científico repousavam, então, numa tendência crescente de monossemantização das suas categorias. O importante era dirigir a leitura até uma interpretação unívoca que reunisse pares, leitores potenciais e o próprio pesquisador/autor. Domínio da épistème, a linguagem científica, resultante de uma simplicidade máxima reduzida a signos fixos e impessoais, não se submeteria a formulações livres. Na verdade, nos rígidos limites da ciência especializada que se então constituía, elas passavam a ser totalmente proibidas. Postulante ao papel de 'condutora das evidências', tal linguagem só poderia mesmo ser entendida como una e invariável (Peytard, 1984; Jacobi, 1984).

E segundo os homens de ciência/cientistas brasileiros, não por acaso, a literatura era a 'liberdade da linguagem'. De onde a aproximação semântica com a 'retórica' e a 'vasta ilustração' na sua conjunção, quase nunca coerente, de argumentos e autores múltiplos numa só obra. Nessa visão, um literato, nas suas deliberações e nos influxos da sua personalidade (que, aliás, seria mesmo estimulada a se liberar), poderia fazer dos seus escritos o que bem lhe aprouvesse, com grande repertório de escolhas de temas - do sertão à Capital Federal - e modos de expressão particulares. Sem obrigações de empenho social, um autor (como um criador de mundos textuais autônomos) e seu texto (livre de quaisquer relações com os eventos externos a si mesmo) não convergiriam necessariamente. A escrita científica, em contrapartida, se exprimiria por intermédio de categorias fixas, submetendo-se ainda à obrigatoriedade de fazer corresponder hipóteses à realidade. Nesse sentido, essa produção intelectual não só buscaria, como exprimiria, decifraria, sendo mesmo capaz ainda de modificar o meio. Depositando nela a sua vida, um 'verdadeiro cientista' se amesquinharia pessoalmente para fazer avultar a sua obra.

No que se refere a toda essa discussão sobre as fronteiras entre a ciência e a literatura, o melhor exemplo para o debate é Euclides da Cunha. Em 1902, por época do lançamento de Os Sertões, nem a formação do autor, tampouco a forma literária do livro, 'esquisita' para alguns, foram problematizadas; ofuscadas como estavam pela consagração do texto como uma maneira totalmente inédita de estudo dos problemas do Brasil (Araújo Jorge. 'Euclides da Cunha', Revista Americana, n. 1, out. 1909, p. 114; Galvão, 1984; Bernucci, 1995; Sevcenko, 1995; Lima, 1997; Abreu, 1998). Na verdade, pode-se argumentar que Cunha foi o Buffon brasileiro, o último 
dos homens de ciência a ser reconhecido pela qualidade da sua composição escrita. Ou seja, o derradeiro dos grandes bacharéis, consagrado publicamente por sua formação intelectual enciclopédica. Por ser exemplar de um tempo de transição, nele buscavam encontrar ora as qualidades de um grande literato, ou a "beleza rara de sua escrita", ora as de um eminente cientista, com o pleno domínio dos termos técnicos. Ao fim, acabavam por conotá-lo como um intelectual de estilos justapostos (Araújo Jorge. 'O último livro de Euclides da Cunha', Revista Americana, n. 7, abr. 1910, p. 66; Roquette-Pinto. 'Euclides da Cunha naturalista', Revista do Brasil, n. 29, maio 1918, p. 22). Mais à frente, no entanto, a categorização de etnógrafo foi utilizada, enfim, para designar-lhe a atividade, já que não poderia mais ser visto como mero engenheiro ou como um simples literato com acentuadas preocupações sociais. E como etnógrafo, exatamente, foi consagrado como um cientista, e mais, como um dos 'precursores' das ciências sociais no Brasil, juntamente com Sílvio Romero e Alberto Torres. Teria sido, na verdade, um 'sociólogo de ofício', um intelectual que acentuava o estudo do meio e a sua influência sobre o destino e o valor dos povos, contribuindo decisivamente para a interpretação de aspectos novos dos problemas sociais do país (A Época, n. 87, ago. 1919, p. 2-3). Como não havia qualquer compromisso com a fiç̧ão na sua obra, não poderia continuar a ser confundido com um 'puro literato', tal como eram considerados Coelho Neto ou João do Rio, por exemplo. E não poderia ser diferente, pois como Cunha se disporia a ser, ao mesmo tempo, um observador da natureza, meticuloso no registro dos fenômenos, pensador austero e grave, subordinado a rígidos métodos e processos de investigação, escrupuloso e de olhar perscrutador, de um lado, e de outro, um estilista, um artista sonhando com fantasias e sentimentos, um intuitivo, um amante inato da beleza da forma e um "embevecido na eterna contemplação de um mundo imaginário”? (Araújo Jorge. 'O último livro de Euclides da Cunha', Revista Americana, n. 7, abr. 1910, p. 66).

'Literatos' e 'cientistas' começavam a ser, então, membros de "dois mundos totalmente diversos, de caracteres próprios e inconfundíveis", gerando, cada um dos grupos, um gênero de escrever que não poderia ser mais distante um do outro. O literário, por exemplo, poderia ser caracterizado como "espontâneo e viçoso, forte, inventivo e criador, como a própria natureza", enquanto o científico, de sua parte, seria para uns "artificial e mirrado, pálido, anêmico e dessorado, como a própria civilização". A opu- 
lência da linguagem era tida, de ambas as partes, como absolutamente imprópria para os livros de ciência pura, assim como os termos técnicos seriam uma fraseologia totalmente inadequada às obras de arte (Araújo Jorge. 'Euclides da Cunha', Revista Americana, n. 1, out. 1909, p. 118; 'Letras e Artes'; Almanaque Garnier, 1907, p. 245; Araújo Jorge. 'O último livro de Euclides da Cunha', Revista Americana, n. 7, abr. 1910, p. 104; Afrânio Peixoto. 'Comparações', Revista Americana, n. 7, abr. 1910, p. 18).

Para o ilustre crítico literário José Veríssimo, os cientistas padeceriam de um "afetado desdém pela literatura". Desprezo que os levava, na verdade, a escrever mal, de modo incorreto e desleixado. Feia, desajeitada e defeituosa, para Veríssimo, nada poderia ser pior do que a escrita científica, verdadeira desonra para a cultura e para a vida do espírito no país (José Veríssimo. 'O movimento literário brasileiro em 1910', Revista Americana, n. 4, abr. 1911, p. 18). E não era o único. Afrânio Peixoto, ele também médico e literato, censurava os "austeros homens de ciência modernos" por estarem por demais apegados à maior "paixão da moda", senão mesmo contaminados pela maior epidemia daqueles tempos: o desmazelo escrito. Acusava-os, em discurso na Academia de Medicina, de empregarem inúmeros esforços para escrever mal, como se isso fosse garantia suficiente, numa só passada, tanto para rejeitar o que consideravam a "frivolidade da forma" quanto para dar provas da sua inteligência científica ('Discursos da Academia de Medicina', Almanaque Garnier, 1909, p. 109). Outros críticos, menos conhecidos, também acusaram os homens de ciência de confundirem o pretenso psitacismo de parte dos escritores brasileiros com toda e qualquer sorte de atividade literária (Moraes Coutinho. 'Despropósitos em torno de um livro', Revista Americana, abr. 1918, p. 94; 'A terminologia científica', Almanaque Garnier, 1907, p. 231). ${ }^{15}$

A resistência dos homens de ciência ao chamado 'papagaismo', ou à arte de alinhar frases ocas e de entoar palavras raras sem a menor intervenção do raciocínio, não é de todo impertinente ('A terminologia científica', Almanaque Garnier, 1907, p. 231). Como já se viu nos capítulos anteriores, a opção pela pompa era plenamente condizente com o gosto literário então em voga, e ainda funcionava como um modo de reagir, pelo zelo da composição escrita, ao predomínio do padrão jornalístico na atividade literária. O que se passava de fato é que toda resistência ao 'bem dizer' e à generalidade da formação intelectual confundia-se mesmo, no discurso científico, com uma reação à escrita literária. Toda e qualquer preocupação com a beleza fraseológica e verbal era coberta das maiores desconfianças. A sonoridade de uma frase era, 
na época, forçosamente interpretada como um impedimento à inteligibilidade do pensamento e como a própria encarnação da vacuidade mental.

Somem-se a todas essas discussões, as considerações sobre as peculiaridades da psicologia dos homens de ciência; sobretudo, se comparados aos seus colegas das atividades literária e artística. Nos cientistas, por exemplo, as células cerebrais se prestariam mais especialmente ao "trabalho constante da perquirição". Seu psiquismo os dotaria de um notável dom de análise para explicar os fenômenos desconhecidos que se manifestariam ao seu redor. Neles, a firme decisão de conhecer seria 'sã', funcionando como um hipersensibilizante para resolver problemas. Nas outras atividades, a vontade de 'abranger saberes' seria antes um sentimento excessivo, uma sorte de desejo ou apetite mórbido que avançaria para os domínios do capricho pueril (Renato Kehl. 'Perlustrações médicas', Revista do Brasil, mar. 1919, p. 305-308). E o que mais avulta nesse tema é a capacidade do controle das paixões. Curiosa fórmula: muita imaginação, fraca vontade; muito pensamento, forte consciência. Nos poetas e romancistas predominaria um intenso egoísmo e uma notória indiferença pela humanidade. Além de uma grande preguiça física, pois a vida imaginosa se prestaria somente ao desfrute, e não aos problemas práticos do mundo, "múltiplas e importantes questões tratadas com alta competência e com calma e severidade próprias aos homens de ciência” ('Discurso do dr. Pinto Portella', Anais da Academia de Medicina do Rio de Janeiro, jun. 1904-jun. 1905, [1906], p. 9). Todo o individualismo dos literatos e artistas, entendido na verdade como sintoma de um romantismo contemplativo já ultrapassado, seria um indício de que viveriam num mundo só deles - universo de sonhos, fantasia e imaginação -, de onde concluíam o seu enfado pela urgência em modificar o meio social (Miguel Ozório de Almeida. 'Missão do intelectual brasileiro' - Arquivo Pessoal Miguel Ozório de Almeida. Centro de Memória/ABL).

Por terem ainda uma vida afetiva exagerada e pelo seu hábito de criar ficções, seriam especialmente dotados para a mentira e frágeis demais para suportar o poder da realidade ou a força da verdade, sempre enfeitadas e mascaradas pelas suas reações ilusórias. Afora isso, como se já não bastasse, por seu individualismo, seriam vaidosos e ciumentos em excesso, desejando ser únicos, famosos e amados sem limites. Nunca se contentariam com o que lhes fora ensinado, querendo sempre saber mais e mais, perscrutando e lendo de tudo um pouco: romances, aventuras poli- 
ciais, poesia e ciência, jornais e revistas. Tudo por vaidade, excentricidade ou exagerado desejo de conhecer, atributos que, como se vê, pareciam excessivamente nocivos (Villar Belmonte. 'Classificação psicológica do homem', Revista do Brasil, n. 102, jun. 1924, p. 99; Dias Ferreira da Silva. 'Relatório dos trabalhos acadêmicos', Anais da Academia de Medicina do Rio de Janeiro, jun. 1904-jun. 1905, [1906], p. 26; Miguel Ozório de Almeida. 'Missão do intelectual brasileiro' - Arquivo Pessoal Miguel Ozório de Almeida. Centro de Memória/ABL, 1939, p. 3; Miguel Couto, 'A alma de Arinos', Revista do Brasil, jun. 1919, p. 179).

Miguel Ozório de Almeida, diretor da seção de fisiologia do IOC e professor catedrático de fisiologia na Escola de Agricultura e Medicina Veterinária, mais especialmente, defendeu a singularidade da psicologia de um típico 'homem de ciência' - um profissional simples, meticuloso, rigoroso, austero, severo, cerebral e diligente. Antípoda dos diletantes, principiantes, curiosos, eruditos ou leigos, que espreitariam a ciência e com ela flertariam por mero hobby (Miguel Ozório de Almeida. 'D. Pedro II e a construção de um Instituto de Fisiologia no Brasil', Revista do Brasil, n. 32, ago. 1918, p. 460). ${ }^{16}$ Segundo ele, um curioso das ciências, "um ignorante da quase totalidade dos seus problemas e questões", não poderia ter a esperança de produzir alguma nova teoria, dado o nível inédito de intrincamento das pesquisas e reflexões científicas ('Missão do intelectual brasileiro', 1939, p. 4 - Arquivo Pessoal Miguel Ozório de Almeida. Centro de Memória/ABL). No mais, parecia mesmo haver entre leigos e cientistas uma acentuada descompensação temporal, segundo qual os imaginativos sem peias alimentavam-se da tradição, enquanto os "homens de inteligência disciplinada" ajudavam a construir o futuro. ${ }^{17}$

Assim, a mentalidade científica, ou a sua especial compleição psicológica, os levava necessariamente a compor relatórios de pesquisa, memórias, diários de laboratório, documentos, textos científicos, correspondências e depoimentos. Aos demais, a aguçada imaginação imporia o primado da criação e aperfeiçoamento da beleza do mundo. ${ }^{18} \mathrm{E}$ já que os homens de ciência/ cientistas se propunham, nas suas obras, a buscar 'toda a verdade' por intermédio de 'pesquisa rigorosa', inadequado seria que o resultado do seu trabalho fosse conotado como arte. Seria, na verdade, “(...) impossível. Mesmo se redigidos no melhor dos estilos, tais escritos não seriam literatura. Era necessário, pois, que nada fosse real ou verdadeiro (...). No fundo (na literatura), o que se encontra sempre é a imaginação do artista" (Discurso de posse do Sr. 
Miguel Ozório de Almeida na Academia Brasileira', Jornal do Comércio, 24/11/ 1935 - Arquivo Pessoal Miguel Ozório de Almeida. Centro de Memória/ABL).

Acrescentem-se a isso, as pretensas diferenças entre inteligência e talento, resultando em distintas manifestações intelectuais. Sendo a inteligência definida como "um aparelho precioso para resolver problemas", uma "faculdade de assimilação e compreensão rápidas", de penetração mais crítica que criadora, era relacionada imediatamente ao exercício científico (Almeida, 1931: 164). O talento, aproximando-se do gênio e da imaginação, prestava-se às atividades das belas artes e ao gosto artístico, carecendo de certo senso das realidades práticas e sempre se suprindo pela auto-educação. Tamanhas diferenças entre duas aptidões do espírito, e que levariam, ao fim e ao cabo, ao exercício de diferentes carreiras intelectuais, poderiam ser também explicadas pela própria diversificação da cultura brasileira, antes "acentuadamente auditiva" e, naqueles tempos, notadamente "visual", com seus impressos, reclames, fotografias e cinematógrafos (José Maria Bello. 'Inteligência e cultura', Revista do Brasil, n. 74, fev. 1922, p. 179). E aquela cultura auditiva, como nas palavras de Maria Bello, palavreadora e múltipla nos ensinamentos, herdada dos portugueses e aqui prevalecente até o limiar do século XX, configuraria intelectuais do porte de Rui Barbosa e Euclides da Cunha, por exemplo: pensadores de "difícil classificação", mas consagrados e reconhecidos por sua "maravilhosa capacidade de assimilação, expressão e eloqüência". No entanto, faltarialhes senso crítico para conhecer, observar, e julgar os eventos que se lhes passavam em torno; tarefa à qual os cientistas se dedicariam quase naturalmente, por certa "intuição psicológica" (José Maria Bello. 'Inteligência e cultura', Revista do Brasil, n. 74, fev. 1922, p. 180). Enfim, se o universo dos diletantes e curiosos era marcado pelos temas da avidez da totalidade de conhecimentos e da paixão inconstante, especializar-se em ciência era um pouco como achar a calma (Pomian, 1987).

No mais, estavam longe da 'cultura auditiva', pois não seriam, por formação e convicção, "homens de palavra fácil" ou que "porfiassem pelo ordinário em dar mostra de oratória campanuda" (Dionísio Cerqueira. 'Oswaldo Cruz', Jornal do Comércio, 06/01/1925 - Arquivo Pessoal Oswaldo Cruz. Centro de Memória/ABL). Na verdade, detestariam discursos, e quando por polidez eram obrigados a fazê-los em grandes solenidades públicas, se eximiam, por decisão, do recurso ao polimento verboso tão 'corrente' nos colóquios e conferências literárias da ocasião. Tudo isso porque tinham 
"horror à declamação, ao artifício, à ênfase, ao entono", e não acreditavam no aprendizado de oitiva, ou de ouvir dizer. ${ }^{19}$ Não se importavam muito com os discursos falados.

No dizer de Juliano Moreira, "os grandes méritos e as grandes idéias dispensam rasgos de eloqüência ao serem proclamados". ${ }^{20}$ A que acudia, por exemplo, Aloísio de Castro, diretor da Faculdade de Medicina do Rio, ao defender peremptoriamente 'a necessidade' da supressão do cargo de orador da ANM. Muito incisivo, Castro perguntava pelos préstimos dessa figura que só servia para desfilar expressões "encomiásticas demais" sobre os recém-chegados, obrigando-os de sua parte a devolver os elogios. E não pelo reconhecimento mútuo dos méritos profissionais, mas por força da etiqueta e solenidade, em suma, das formalidades tradicionais. ${ }^{21}$ Era muito difundida entre eles a opinião de que "quem não tem idéias para colocar, já coloca bem os pronomes...à portuguesa". E se, no seu esquema, o refinamento da linguagem não passava de artifício para ocultar a falta de pensamento, poucas questões podiam preocupá-los tanto quanto o chamado "bizantinismo da expressão". ${ }^{22}$ Em outras palavras, o fraseado simples seria totalmente condizente com o modo moderno de pensar.

De outro modo, como já se sabe, grande parte das atividades então reconhecidas como 'científicas' enleavam-se com a prática da medicina. Com isso, a geração de homens de ciência/cientistas de que vimos tratando também defendia a sua profissionalização como um ofício cada vez mais distante do exercício exclusivo da clínica médica, pautada antes, na sua visão, pela observação à beira dos doentes e pelos meros comentários teóricos lidos nos livros que pela experimentação. Alguns daqueles cientistas, como Oswaldo Cruz e Miguel Ozório de Almeida, por exemplo, dedicados, como argumentavam ser, aos estudos experimentais, passavam a revelar sistematicamente que, a despeito de sua formação original em medicina, detestavam clinicar, passar receitas, "ver a língua", "tomar o pulso", e ser confundidos com "boçais curandeiros". E não eram os únicos. Mas, para "atirar-se à pesquisa", como mencionaram, relatavam ter a consciência de que, na falta de outras instituições especializadas, precisavam passar pelas cadeiras das faculdades de medicina (Miguel Ozório de Almeida. 'Convidando uma geração a depor: um autêntico homem de ciência', O Jornal, 11/08/1935 - Arquivo Pessoal Miguel Ozório de Almeida. Centro de Memória/ABL; Roquette-Pinto. 'Discurso em homenagem a Miguel Couto', Jornal do Comércio, 22/06/1934 - Arquivo Pessoal Miguel Couto. 
Centro de Memória/ABL; Roquette-Pinto, Vamos ler!, 23/03/1939, p. 48 Arquivo Pessoal Edgard Roquette-Pinto. Centro de Memória/ABL).

Àquela altura, os aspirantes à especialização diziam sentir-se desimpedidos do peso morto dos sábios eloqüentes e dos observadores acurados. A 'ciência por empréstimo' já era, nesse meio científico carioca, bastante desvalorizada; isso quando a falta de originalidade nas pesquisas científicas, ou o "saber falar pelos livros", não era mesmo relacionada ao plágio ou à cópia das idéias dos outros ('Ladrões intelectuais', Revista do Brasil, n. 18, jun. 1917, p. 265). No mais, se antes se configurava no Brasil "uma aristocracia da medicina", com seus funcionários e burocratas "personalizados na vaidade sem proveito", nos novos tempos reinava a "democracia da ciência", pondo ao alcance de todos os talentosos e estudiosos a possibilidade de desenvolver seus dons, de pesquisar, apresentar e tomar novas direções na produção dos saberes científicos (Afrânio Peixoto. 'O que abala as montanhas', O Jornal, 11/02/1927 - Arquivo Pessoal Oswaldo Cruz. Centro de Memória/ABL).

Oswaldo Cruz e Adolfo Lutz, diretor do Instituto Bacteriológico de São Paulo, por exemplo, ao contrário dos sábios que os antecederam, teriam escrito pouco e sequer teriam lecionado em faculdades ou academias. Por sua formação especializada, ainda mais no estrangeiro, eram tidos e sublinhados como homens do "laboratório", homens das "evidências", do "esforço", da "pesquisa", da "ação" e do "trabalho" (Abreu Fialho. 'O Instituto de Manguinhos', Renascença, n. 32, out. 1906, p. 129-140). ${ }^{23}$

É digno de nota ainda que, no seu dizer, nenhum desses dois 'exemplares homens de ciência' tinha ares de 'mestre superior' com seus subordinados. Não queriam discípulos ou admiradores, mas apenas 'companheiros', para, juntos, descobrirem novidades na ciência. Na verdade, os 'verdadeiros cientistas', a despeito da sua fama ou especial proeminência profissional, deveriam trabalhar coletivamente, entregando-se ao trabalho árduo, disciplinado, exclusivo e especialmente intrincado tal como era, a seu ver, a atividade científica. E não eram insubstituíveis porque essa nova geração não só acreditava como defendia a reprodutibilidade dos saberes científicos.

Sucede assim que, nos seus textos, a imagem da carreira científica como sacerdócio ou 'chamado do destino' tende cada vez mais a ceder lugar para a afirmação da ciência como profissão. A sua atividade, com as suas novas representações, era apresentada como um saber decifrável somente para os seus iniciados. A ciência seria difícil, pouco acessível, exigindo formas de educação, de inteligência e modalidades de espírito especialmente 
"talhadas para o gênero de dificuldades que enfrentam", (Miguel Ozório de Almeida. 'Missão do intelectual brasileiro', 1939, p. 7 - Arquivo Pessoal Miguel Ozório de Almeida. Centro de Memória/ABL).

Cabe também lembrar que essa geração foi herdeira direta das mudanças ocorridas no método de estudos e pesquisa em ciências naturais. Cada vez menos partilhavam do método sistemático e taxonômico da história natural (Lopes, 1997). E para Miguel Ozório, por exemplo, a ciência, tal como feita anteriormente no Brasil, limitava-se a sistematizar conhecimentos - prática que não exigiria do homem de ciência aos velhos moldes nenhum esforço adicional da inteligência, bastando-lhe possuir boa memória e disponibilidade para a contemplação. Para ele, antes da segunda metade do século XIX, por absoluta ausência de capital científico ou de invenções e descobertas inovadoras, só teria sido possível recolher, observar, registrar e descrever as características morfológicas do material estudado, criar sistematizações, agrupar, organizar e classificar conhecimentos e fenômenos segundo as suas analogias. O que movia os homens de ciência do século XIX, no seu entender, era uma instintiva curiosidade, feita de uma nostalgia romântica de uma totalidade inatingível.

Para ele, os 'homens de ciência' brasileiros do século XIX não tinham um perfil bem delimitado à vista das demais carreiras intelectuais, por pertencerem, como os literatos, a uma 'cultura da memória' então bem predominante. E porque vontade de reter o máximo possível de informações, um homem de ciência 'antigo' lia, lia e repetia o que encontrava nos livros, assim como recolhia indiferentemente tudo com o que se deparava no caminho. Sua geração, de outro modo, pertencia ao que chamava de 'a cultura da inteligência' ('A necessidade de esquecer', Revista do Brasil, n. 108, dez. 1924, p. 315).

Ao insistir nesses pontos, essa geração acreditava romper com todos os valores que informavam a atuação dos 'literatos' com o seu delírio da personalidade na criação, o transbordamento de todas as balizas da imaginação e certo egocentrismo letrado. ${ }^{24}$ Pretendia salientar, em suma, o valor que atribuía à objetividade, à observação, à experimentação e ao meio físico e psicológico. Era forte a resistência à estetização do discurso científico, pois, no limite, sucumbir à estilização do mundo conotaria não só falta de seriedade profissional, como a própria ausência de isenção científica no trato do material de pesquisa. 
Ademais, quanto mais complexas e modernas, mais as sociedades, segundo eles, seriam movidas pela 'lei geral da divisão do trabalho'. E a convergência de esforços em áreas particulares do conhecimento, cada qual com sua devida função no tecido social, já os teria, de pronto, encaminhado a uma grande diversificação dos seus locais de trabalho. Os lugares mais antigos, como a ANM e o MN, começavam, por exemplo, a ser reformulados pelo 'novo espírito científico' no seu incessante estímulo aos estudos experimentais, e, segundo o qual outros também vinham sendo fundados, como associações, laboratórios de análise, institutos bacteriológicos e vacínicos, ligas e agremiações científicas e médicas. Isso tudo sem contar os intercâmbios internacionais e os boletins e revistas nos quais poderiam demonstrar como desenvolviam, pesquisavam e solucionavam os problemas que lhes eram afeitos: cada grupo na sua área especial de atuação ('Discurso do dr. Alfredo do Nascimento', Anais da Academia de Medicina do Rio de Janeiro, jan.-dez. 1908, [1911], p. 8).

Por serem pesquisas especializadas e diversificadas, seriam, portanto, mais aperfeiçoadas. Compleição psicológica e cultura técnica compatível com a especialidade preferida: a soma desses dois elementos resultaria num competente cientista (Liberato Bittencourt. 'Psicologia do sucesso', Revista Americana, n. 9, jun. 1917, p. 43). E esse novo espírito científico que defendiam levaria à formação do 'cientista' como um experimentador, como aquele que provoca a natureza arrancando-lhe seus segredos. À parte isso, deveriam, tão-somente, estar envolvidos na reforma das instituições a que pertenciam, na solicitação de verbas para as suas pesquisas e laboratórios e na preparação de cursos e de textos científicos originais ('Discurso do dr. Carlos Seidl'. Anais da Academia de Medicina do Rio de Janeiro , jan.-dez. 1913, [1916], p. 12-13).

Ao homem de ciência, como na acepção mais difusa do termo até então, não mais bastaria ser um livre-pensador, dotado de boníssimas virtudes espirituais, de um grande amor pela ciência, pela verdade ou por um sincero desejo de servir à humanidade a despeito de quaisquer intempéries de ordem pessoal ou financeira (Couto, 1842: 351; Vieira, 1871: 424, v.5; Figueiredo, 1899: 510, v.2). De um 'cientista' se deveria exigir dedicação exclusiva.

A ciência já começava, então, a ser considerada um conhecimento especializado, extremamente particular, plenamente moldado à ânsia de inovar e à agitação tão próprias aos tempos modernos. E um "cientista 
moderno" era alguém que deveria ser "exclusivamente pesquisador", dedicando todo o seu tempo aos trabalhos originais. A propósito, Álvaro Ozório de Almeida, professor da Faculdade de Medicina do Rio, apresentou um resumo lapidar e por demais completo dos seus ideais profissionais: a ciência deveria "ser uma carreira provendo as necessidades da vida de cada um; e assim deve ser pelo seu grau de especialização e por absorver todo o tempo e toda a inteligência de seus servidores" ('O problema universitário', Ciência e Educação, n. 5, jun. 1929, p. 4). E, na sua representação, 'unidade temática' somada a 'tempo hábil', para formular hipóteses e perseverar na repetição de situações que configurassem os mesmos resultados demonstrando a solidez das suas pesquisas, não era um ideal profissional que atinasse com a contemplação desimpedida e seduzida das belezas e encantos da vida.

Com tudo isso, os aspirantes a cientistas continuavam sendo acusados de reduzirem, quase mecanicamente, a beleza de uma frase à nulidade do que diz. E o 'escrever bem" poderia ser tão grave aos seus olhos que, dizia um crítico literário do período, os homens de ciência receavam o encanto das palavras tal como os pescadores temiam o canto das sereias, valendo a metáfora por corromperem "o oceano austero do pensamento com a brancura irreal dos seus corpos femininos". ${ }^{25}$ Daí notarmos nos homens de ciência, segundo ele, um esforço muito vigilante e decidido para sufocar a qualidade da escrita, criando uma prevenção contra a literatura num sentido geral. Havia nisso certo exagero. E os homens de ciência/cientistas replicavam de sua parte, alegando que, na verdade, a escrita literária era tão postiça e afetada que tinham dificuldades em distinguir o "gênio" do "exagero", o "espírito artístico" da "ênfase forçada". No seu dizer, faltava-lhes bom senso numa escrita sempre "em borbotões, tumultuosa e célere qual rio caudaloso e acidentado" ('Discurso do dr. Rocha Faria', Boletim da Academia Nacional de Medicina, n. 1, 1919, p. 107).

Méritos teriam os textos científicos, plácidos, serenos e de transparência cristalina com suas "palavras poucas, frases curtas e breves períodos". Textos feitos antes para serem lidos que ouvidos, pois neles a vivacidade das idéias valeria mais do que a pompa verbal, utilizada para prender a atenção da platéia e não para ensinar (Carlos Seidl. 'Relatório do ano acadêmico', Anais da Academia de Medicina do Rio de Janeiro, jul.-dez. 1906, p. 25).

No mais, conforme delimitavam, os cânones do período exigiam que a composição de um texto científico obedecesse a parâmetros de síntese e 
conclusão, afirmação e confirmação de hipóteses, encaminhando-os, à revelia mesmo da sua vontade, à singeleza e à desafetação da linguagem. De sua parte, os textos literários, comprometidos como estavam em agradar os ouvidos dos espectadores, não faziam mais do que lançar belas e prazerosas palavras ao vento. Carecendo de concisão, sobriedade e utilidade social e, sobretudo, fazendo uso dos sentimentos e das seduções da linguagem, que mais poderiam ser que não um lazer para "perfumar a existência"? (Roquette-Pinto. Discursos Acadêmicos, 1937, p. 82).

\section{Notas}

1 Cabe frisar que esse tema da internacionalização da ciência não se confunde com a idéia da 'difusão' das teorias européias. E para a produção intelectual brasileira, não há qualquer demérito que a qualifique como mimética ou plagiadora. No mais, pela velocidade com que se punha a par das teorias européias, atrasada certamente não era. De todo modo, como já se discutiu em capítulos anteriores, tudo isso só demostra seu forte empenho civilizador e modernizador, assim como a sua ânsia de equiparar a produção cultural realizada no Brasil à dos demais países de 'ponta' no nível do século. Sobre as idéias sem fronteiras, ver Prochasson (1994) e Juillard (2001).

2 A imagem é de Christophe Prochasson (1989).

3 Edler (1992, 1999) chama a atenção para a historicidade das regras de produção de verdades, pois foi só com o triunfo da medicina pastoriana, em fins do século XIX, que o paradigma climático-telúrico ganhou a pecha de acientífico, senão mesmo de 'crendice'. Nas suas pesquisas, Edler demonstra a força dessas teses ambientais para a organização da profissão médica, para a criação da Academia Imperial de Medicina e para o fortalecimento de uma cultura médica que revisava e discordava dos tratados europeus sobre patologia e higiene.

4 Estudiosos sobre o tema salientam o 'caráter híbrido' dos bacteriologistas nesse período de institucionalização da microbiologia no Ocidente. Teriam atuado, ao mesmo tempo, como médicos, pesquisadores e sanitaristas, numa alusão à concomitância dos seus estudos sobre os micróbios e sua intervenção no 'meio'. Para Latour (1988, 1984), a clínica centrada na microbiologia, entre o final do século XIX e o início do século XX, ainda formava médicos aos contornos de 'cientistas do ambiente', já que preparados para atuar sobre doenças de constituição endêmica. No seu dizer, uma análise da consolidação da medicina microbiológica aponta para uma combinação com os princípios da medicina climático-telúrica. Sobre a aliança da microbiologia com os saberes médico-científicos do século XIX, ver também Caponi (2000, 2002a, 2002b, 2003) e Löwy (1994).

5 Cabe salientar que as visitas se realizavam segundo as especialidades dos participantes. Enquanto, por exemplo, os de ciências jurídicas visitavam o Supremo Tribunal e a Biblioteca Nacional, os de engenharia seguiam para a Escola Politécnica, e os de ciências médicas para a ANM. Para maiores detalhes ver, Brazil (1909). 
6 No Tomo I dos relatórios constam as propostas de trabalho a serem apresentadas no encontro, tais como as referentes à uniformização da terminologia técnico-matemática, à uniformização da terminologia em engenharia, à uniformização da terminologia médica, e discussões intensas sobre a pedagogia a adotar no ensino prático (Freitas, 1906). Sobre o Congresso, ver também Andrade (2002).

7 Note-se que, nesse período, não havia uma separação nítida entre as ciências sociais e as ciências naturais. A antropologia era uma ciência natural, enquanto a sociologia imiscuía-se ao direito. As ciências sociais aproximavam-se da medicina e da educação, nas quais o tema da reforma social foi discutido. E nessa aproximação pelo tema da reforma, as ciências sociais e as da saúde estiveram especialmente interligadas. Cf. Carvalho e Lima (1993); Lima e Hochman (1996); Carvalho (1997); Lima (1999).

8 Manuscrito inédito encontrado no seu arquivo pessoal sob a guarda do Centro de Memória da ABL, caixa 24, [s.d.].

9 Manuscrito inédito encontrado no seu arquivo pessoal sob a guarda do Centro de Memória da ABL, caixa 24, [s.d.].

10 E para reforçar a hipótese de Moreira, há notícias, por exemplo, na revista parisiense La Science au XXème Siècle, que atestou nas suas páginas a qualidade das pesquisas de Ribas e de Lutz sobre a febre amarela, acrescentando que "convenceram o mundo científico". Edmond Sergent ('La fièvre jaune'. La Science au XXème Siècle, n. 15, mar. 1904, p. 74). O Almanaque Garnier de 1909 traz reproduções dos jornais franceses de 1907 exaltando as proezas científicas do Instituto de Manguinhos e a medalha de ouro ganha pela instituição brasileira por época da Exposição de Higiene em Berlim. Segundo essas notícias, o mérito dos cientistas brasileiros era incontestável, notadamente o de Oswaldo Cruz, pois "o Instituto de Manguinhos expôs trabalhos que na opinião dos cientistas de todos os países tinham, sem dúvida alguma, um grande valor científico" (p. 168-170). Outros cientistas também eram igualmente incensados pelo seu presumido êxito no exterior: Miguel Ozório de Almeida seria citado em todos os grandes livros alemães de fisiologia moderna, sendo que, nos índices bibliográficos dessas importantes obras, seu nome era repetido "cinco, seis, dez vezes em seguida" ('Convidando uma geração a depor: um autêntico homem de ciência', O Jornal, 11/08/1935 - Arquivo Pessoal Miguel Ozório de Almeida. Centro de Memória/ABL). Vale citar ainda que, como fisiologista, Ozório ganhou o prêmio Sicard pela Faculdade de Medicina de Paris. E ele próprio, em artigo para a imprensa brasileira, atestou a enorme admiração que os cientistas europeus teriam pelo "trabalho fácil, atraente e original" de Roquette-Pinto ('Roquette-Pinto e o Brasil', Jornal do Brasil, 09/04/1941 - Arquivo Pessoal Miguel Ozório de Almeida. Centro de Memória/ABL). Sobre o 'sucesso' dos homens de ciência/cientistas brasileiros na Europa, ver também 'Um sábio brasileiro' (Ciências e Letras, n. 7, set. 1916, p. 134-136).

${ }^{11}$ Discurso de Aloísio de Castro. 'Centenário da organização do Ensino Médico', Anais da Academia do Rio de Janeiro (jan.-dez. 1908 [1909], p. 44); Juliano Moreira. 'Oswaldo Cruz (1872-1917)', Revista da Sociedade Brasileira de Ciências, n. 1, 1917, p. 107-111; Dionísio Cerqueira. 'Oswaldo Cruz', Jornal do Comércio, 06/01/1925 - Arquivo Pessoal Oswaldo Cruz. Centro de Memória/ABL; 'No mundo das curiosidades', A Noite, 09/ 02/1925 - Arquivo Pessoal Oswaldo Cruz. Centro de Memória/ABL.

12 Roque Spencer Maciel de Barros (1986) sublinhou as diferenças entre o humanismo clássico e seu ideal pedagógico, próprio a uma sociedade aristocrática, e as teorias cientificistas, defendendo ideais educativos de uma sociedade democrática. 
13 Aloísio de Castro. 'Discurso em homenagem a Miguel Couto', Boletim Farmacêutico Silva Araújo, ano XXII, n. 88, nov. 1923, p. 16 - Arquivo Pessoal Miguel Couto. Centro de Memória/ABL.

14 Astrônomo e biológo, Benignus se lança numa expedição científica ao interior do Brasil. Destacado por um ser espiritual vindo das 'regiões sidéreas' para ser um sacerdote do bem da humanidade, Benignus fica extasiado com as belezas naturais, e, ao fim, decide afastar-se do convívio com os homens, sacrificando a sua missão à contemplação da natureza (Zaluar, 1994).

15 Por serem uns "defensores das ciências particulares", os cientistas seriam ainda uns "esnobes" devido ao seu acentuado desprezo à metafísica, à filosofia, à religião e àqueles que tão simplesmente "acreditam abraçar o conjunto do saber" (Jonatas Serrano. 'Filosofia e ciência', Revista Braziléa, n. 11, nov. 1917, p. 559-561).

16 O tema também aparece na saudação do dr. Arnaldo Quintella à criação do prêmio 'Alvarenga' na Academia Nacional de Medicina. Anais da Academia de Medicina do Rio de Janeiro, jan.-dez. 1913 [1916], p. 56.

17 A expressão é de Antonio de Paula Freitas (apud Ferreira, 1989: 112).

18 Miguel Ozório de Almeida. 'A necessidade de esquecer, Revista do Brasil, n. 108, dez. 1924, p. 322. O tema também aparece no 'Discurso de posse do Sr. Miguel Ozório de Almeida na Academia Brasileira', Jornal do Comércio, 24/11/1935 - Arquivo Pessoal Miguel Ozório de Almeida. Centro de Memória/ABL; 'A ciência e a língua portuguesa', Revista do Brasil, n. 94, out. 1923, p. 149; 'Convidando uma geração a depor: um autêntico homem de ciência', O Jornal, 11/08/1935 - Arquivo Pessoal Miguel Ozório de Almeida. Centro de Memória/ABL.

19 Aloísio de Castro. 'Discurso em homenagem a Miguel Couto'. Boletim Farmacêutico Silva Araújo, ano XXII, n. 88, nov. 1923, p. 16 - Arquivo Pessoal Miguel Couto. Centro de Memória/ABL.

2) Juliano Moreira. 'Discurso em homenagem a Miguel Couto'. Boletim Farmacêutico Silva Araújo, ano XXII, n. 88, nov. 1923, p. 36 - Arquivo Pessoal Miguel Couto. Centro de Memória/ABL.

21 Depois de toda essa discussão, ficou enfim acordado que o orador oficial, dali em diante, discursaria somente nas sessões solenes (Anais da Academia de Medicina do Rio de Janeiro (jun. 1904-jun. 1905 [1906], p. 142-146). No entanto, o então titular do cargo, o dr. Fernando Magalhães, quis defender o seu posto. Em atrasado mas eficiente discurso resguardou a "santidade das palavras" como o recurso indispensável de entronização num cerimonial de "canonização profana", tal como era aquele da recepção e posse de novos membros; grandes profissionais da medicina, "nossos beneméritos e nossos heróis", merecedores do reconhecimento de todos os demais membros da casa. E ainda perguntava, que grande mal podia haver, afinal, num encantador ritual acadêmico de festejo das "grandes glórias e conquistas da ciência"? (Anais da Academia de Medicina do Rio de Janeiro, jul.1905- jun.1906 [1906], p. 23).

22 'Discurso do Sr. Presidente da Academia Brasileira, o dr. Afrânio Peixoto, na última sessão de 1922' - Arquivo Pessoal Afrânio Peixoto. Centro de Memória/ABL.

23 Oswaldo Cruz, depois de formado pela Faculdade de Medicina do Rio, morou em Paris, de abril de 1897 a agosto de 1899, de modo a especializar-se em microbiologia no Institut Pasteur. Lutz, de sua parte, formou-se em medicina, em 1879, na Suíça, 
tendo freqüentado, nos anos seguintes, laboratórios na Alemanha, na França e na Inglaterra. A essa formação especializada no exterior pode-se somar a notoriedade pública que conseguiram pela eficácia e precisão do seu diagnóstico em doenças específicas: Cruz, no Rio de Janeiro, para a febre amarela, e Lutz, em São Paulo, para a febre tifóide. Notabilizaram-se, pois, num campo específico de pesquisa e de atuação em ciência: a medicina tropical. Cruz ganha o cetro de primeiro dos especialistas pela 'publicidade' que conheceu ainda em vida como um 'cientista experimental' a quem as doenças não podiam fazer frente graças, exatamente, à eficácia do seu saber.

${ }^{24}$ A que, de sua parte, os literatos não replicavam. A modelização da escrita científica era associada à "fórmula política da democracia e do igualitarismo", por serem cientistas aclamados como "contrários às individualidades". Com isto, nivelariam, uniformizariam e despersonalizariam em demasia o trabalho intelectual. A "fórmula estética", de outro modo, "é mais diferenciadora, porque a beleza é um padrão de supremacia e volúpia egoística, de aristocratismo intelectual, de exceção, de vida autônoma e de personalidade" (Assis Chateaubriand. 'Machado de Assis', Revista do Brasil, n. 26, mar. 1918, p. 310). Sobre o mesmo tema, pode-se consultar ainda Amadeu Amaral ('Em torno de Machado de Assis', Revista do Brasil, n. 27, abr. 1918, p. 363).

25 A. Moraes Coutinho ('Despropósitos em torno de um livro', Revista Americana, n. 7, abr. 1918, p. 95) - crítica ao livro Rondonia, de Edgard Roquette-Pinto. 


\section{Academias e Sociablilidades}

Ser só cientista é limitado.

Ser só literato é superficial.

Afrânio Peixoto (O Globo, 09/11/1925 - Arquivo Pessoal

Afrânio Peixoto. Centro de Memória/ABL)

Na noite do dia 28 de maio de 1917, realizou-se, no Teatro Municipal do Rio de Janeiro, uma solene sessão pública em homenagem à memória de Oswaldo Cruz, falecido em fevereiro daquele mesmo ano. Dentre as falas de todos os reverenciosos, homens de ciência, amigos e legatários de Cruz, a mais concorrida conferência foi proferida por ninguém menos que Rui Barbosa. No ato final dessa história, nenhuma apoteose poderia ser mais significativa: o maior e mais famoso enciclopédico, em cerimônia de gala, discorrendo sobre o mais cultuado e o primeiro dos grandes especialistas!

Rui Barbosa, de sua parte, não poderia ter oferecido ao público uma recapitulação do panorama intelectual do país nos anos anteriores mais afável aos seus já convencidos ouvidos de 'precursores da bacteriologia no Brasil'. De início, mencionou os "cultores apaixonados" dos saberes médicos no século XIX e todos os demais "curiosos" e "diletantes", sorvendo dos livros as idéias européias, "chão de areia nua e rasa" a partir do qual, e por muita força, teria brotado a ciência do laboratório no século XX, assim como o trabalho austero, exigente e severo, a técnica escrupulosa e a sábia disciplina da cultura experimental. E no seu dizer, Cruz teria sido, nada menos, que o grande pioneiro desse 'novo' modo de fazer ciência no Brasil - com inteligência, originalidade, experimentação exata e verificação rigorosa. Quanto mais não seja, teria sido o idealizador e o construtor 
de uma instituição que, finalmente, agregara os esforços dos 'cientistas', reunindo-os em atividades coletivas, nas quais teriam podido fundir seus especiais saberes, trocar idéias e edificar um conjunto completo do conhecimento científico sobre as "coisas nacionais". Oswaldo Cruz seria, enfim, a personalidade que representava o Brasil moderno (Rui Barbosa. 'Oswaldo Cruz', Revista do Brasil, n. 19, jul. 1917, p. 271-304). O mesmo Brasil moderno onde parecia já não mais caber uma 'vasta inteligência' como aquela que sustentara, nos últimos anos do Império e primeiros anos da República, a notoriedade pública do próprio Rui Barbosa, que, dizia o povo, falava todas as línguas de todos os países do mundo, tendo tido ainda a disposição de ler todos os livros do planeta (Costa, 1989).

A discussão sobre a especialização intelectual andou a passos largos nos primeiros anos do século XX. A adoção de novos cânones teóricos que presumiam a fixidez e a especificidade da linguagem científica; a eficácia técnica das intervenções sanitárias dos médicos e cientistas, que, além de tudo, ainda tinham desnudado o depauperamento dos rincões do Brasil; a valorização da divisão social do trabalho nos países europeus que se industrializavam e se urbanizavam; a modernização da Capital Federal e a sensação generalizada tanto de afastamento da herança colonial portuguesa quanto da obrigatoriedade da otimização do uso do tempo; e a fundação da Academia Brasileira de Letras (ABL), suscitando a demanda pela profissionalização dos literatos, foram alguns dos eventos que ajudaram a fortalecer a importância da delimitação das fronteiras entre os ramos do saber.

E a ABL era mesmo um 'termômetro' a medir o grau de ajustamento da identidade profissional dos intelectuais da cidade, sobretudo dos 'cientistas', os mais dedicados, já se sabe, na circunscrição do seu ofício. Por ter falhado em reunir os 'puros literatos' que seguiam lutando pela profissionalização fora dos seus muros e por receber os homens de ciência/cientistas, que não se cansavam, nos seus textos publicados nas revistas e jornais, de fazer equivaler a 'arte da palavra' à falta total de idéias, foi alvo certo dos praticantes da pena que se viam preteridos pelos técnicos de uma escrita orgulhosamente seca e nada imaginosa. Tamanha gritaria, como se verá a seguir, só atesta a distância entre os mesmos Rui Barbosa e Oswaldo Cruz. 


\section{Velhos Moldes, Novos Figurinos}

A eleição de Oswaldo Cruz para a ABL, em maio de 1912, causou muito espanto e não ficou incólume na imprensa da cidade. Toda essa perplexidade foi fruto dos primórdios da especialização entre a literatura e a ciência por um lado, mas foi também, por outro, uma grande estimuladora dos próprios critérios de separação entre ambas.

Com Oswaldo Cruz concorrera o literato boêmio Emílio de Menezes num pleito muito disputado: Cruz ganhou a vaga por doze votos contra os dez dados a Menezes. O escândalo com a sua eleição se prorrogou até o ano seguinte quando, em 26 de junho de 1913, Cruz tomou posse agradecendo, em cuidadoso discurso, a "especial indulgência" dos acadêmicos em aceitar a presença de "um modesto homem de laboratório" entre os que formavam a elite da intelectualidade brasileira. Na obrigatória dissertação sobre a obra do seu antecessor, Raimundo Correia, Cruz destacou as 'afinidades' entre ambos, já que o poeta teria verdadeiro pavor das doenças contagiosas, das quais ele, exatamente, se ocupava em extinguir. Reconhecido, ressaltou, contudo, que prezava, acima de todas as outras coisas na vida, a sua "profissão de cientista", fazendo corar ainda mais os acadêmicos que não viam com simpatia a sua admissão ('Discursos proferidos na Academia Brasileira', Revista Americana, n. 7, jul.-ago. 1913, p. 2). Carlos de Laet, por exemplo, poucos dias após a eleição de Cruz, havia exigido em discurso o esclarecimento e a fixação definitiva das condições de admissão na Academia. Laet dizia não se conformar com essa ambigüidade entre as carreiras literária e científica, cada vez mais inadmissível no mundo que os cercava, mas plenamente praticada numa instituição que, originalmente, deveria ser só de letras. ${ }^{1}$

À revelia de todos os descontentes, Cruz foi recepcionado no silogeu por Afrânio Peixoto, em defesa hábil e apaixonada do ingresso do 'Pasteur brasileiro' naquela 'casa de notáveis'. Peixoto destacou o exemplo da Académie Française, a confessada matriz da ABL, que prestava suas homenagens aos mais altos expoentes da cultura geral daquele país, incluídos todos os literatos, cientistas, filósofos, prelados, chanceleres, militares, sábios, poetas, romancistas, historiadores, oradores, dramaturgos e filólogos. E tudo isso porque as academias seriam, do seu ponto de vista, muito femininas "sempre procurando possuir todas as jóias ao seu alcance". A justificativa proposta por Peixoto girava, mais uma vez, em torno das dissonância e contradição quando do emprego da idéia de 'literatura'. No seu dizer, não discor- 
dava que fosse primordialmente a 'arte de ficção', mas não via impedimentos em nela abrigar toda e qualquer produção intelectual, garantindo vaga na Academia aquela que fosse de qualidade (Arthur Motta. Academia Brasileira de Letras', Revista do Brasil, n. 50, fev. 1920, p. 152; 'Discursos proferidos na Academia Brasileira', Revista Americana, n. 7, jul.-ago. 1913, p. 20).

No mais, Peixoto argumentou que o imperativo da especialização entre a ciência e a literatura era então muito recente, não havendo, até aquela ocasião, uma diferença essencial entre ambas, e que fosse aceita por todos os letrados sem nenhuma sombra de controvérsias. E pela novidade, não haveria ainda canais suficientes de consagração para os 'cientistas'. Nesse caso, a Academia, ciente do seu quase solitário papel em tão amorfo período de transição, pretenderia somente fazer justiça à inteligência brasileira. ${ }^{2}$ Peixoto alegava que era "tão medíocre expelir as ciências dentre as letras, como seria exigir que só se considerem estilistas aos que escreveram com um estilete". E ainda questionava: quais seriam as tão propaladas "enormes diferenças" entre aqueles que distraem os outros com as suas imagens, figuras, intrigas, rimas e melodias, conduzindo-os fora da vida cotidiana para o sonho, e os que preparam uma vida mais fácil e benigna, pela dominação de todas as forças naturais para o conforto, saúde e segurança da humanidade? Não proporcionariam, ambos, bem-estar aos demais? Tantas reclamações contra os homens de ciência na ABL revelaria ainda, no seu entender, uma enorme ingratidão da população com a ciência ('Discursos proferidos na Academia Brasileira', Revista Americana, n. 7, jul.-ago. 1913, p. 21-25). Eleito e empossado, Cruz, no entanto, não freqüentaria a Academia. Com tantas críticas de todos os lados, recusou-se a participar das suas reuniões.

Anos depois, a polêmica ainda ardia na imprensa da cidade, até porque médicos e 'cientistas' continuavam sendo admitidos na ABL. Conta-se que o vencido Emílio de Menezes seguia respondendo com grande escárnio aos comentários sobre a sua derrota para um 'não literato', ironizando num só movimento tanto a trajetória científica de Cruz quanto o tão recorrente argumento do precedente da Academie Française para as eleições da Academia Brasileira: "O Dumas Filho por exemplo. O Dumas foi eleito por causa dos Três Mosqueteiros. Por que não ser eleito o Oswaldo que tem milhares de 'mosquiteiros', toda uma brigada de 'mata-mosquitos'?".

Ainda sobre o mesmo tema, o responsável pela seção 'Academia Brasileira de Letras' da Revista do Brasil, Arthur Motta, fez a mais consistente 
crítica à circulação dos homens de ciência na agremiação literária. Motta argumentou que a explicação do 'critério dos expoentes', tomado de empréstimo do caso francês, não seria suficiente para fundamentar a sua admissão na ABL, posto que o Institut Français, sede da Academia Francesa, subdividia-se, na verdade, em outras cinco associações: Ciências, Ciências Morais e Políticas, Inscrições, Belas Letras e Belas Artes, não tendo a Academia Francesa, portanto, o complemento restritivo 'de Letras', como sucedia com a brasileira. Nesse caso, nada mais compreensível que, na França, ao lado dos nomes mais representativos da literatura figurassem notáveis e 'puros cientistas', como Pasteur e Claude Bernard, entre outros. Eram eleitos por serem 'glórias nacionais' e não pelo mérito exclusivo das suas produções intelectuais. E se os 'cientistas' brasileiros, de sua parte, não tinham o menor constrangimento em adentrar na $\mathrm{ABL}$, então, por exemplo, por que nenhum poeta ou prosador era admitido na Academia Nacional de Medicina (ANM)? E mais, por que não criavam as suas próprias associações, academias e corporações já que tanto repetiam nos seus escritos, desdenhando das demais, que só porfiavam na órbita particular das suas especialidades? Se rejeitavam, com tantos argumentos e maledicências, os diletantes das ciências, porque afinal se achavam no direito de dedicar-se incidentemente a temas tão estranhos às suas respectivas formações? Por fim, confessou que não pretendia com tudo isso menosprezar o valor indiscutível de um Oswaldo Cruz, um dos mais controversos membros da ABL. Mas, em fina ironia, simulou reconhecer os poemas que lhe abriram as portas da Academia. E ele mesmo sugeriu: o "Instituto Oswaldo Cruz, o extermínio da febre amarela e da profilaxia de outras enfermidades. Os seus melhores romances foram a sua vida consagrada à ciência e a ação higienista na região amazônica" (Arthur Motta. 'Academia Brasileira de Letras', Revista do Brasil, n. 50, fev. 1920, p. 155-159).

Quando Cruz morreu, foi substituído por outro famoso homem de ciência, o médico Aloísio de Castro, a quem atribuía-se "inveterado amor pelos clássicos", e, logo, maior mérito na admissão como membro da ABL ('Seção Academia Brasileira de Letras', Revista do Brasil, n. 50, fev. 1920, p. 160). Castro, de sua parte, disfarçava seu orgulho dizendo não ter argumentos que justificassem, nem mesmo aos seus olhos, a sua admissão na Academia ('Discursos proferidos na Academia Brasileira', Revista Americana, n. 8, maio 1919, p. 120). Discorrendo no seu discurso de posse sobre a obra do antecessor, em 15 de abril de 1919, Castro reconheceu a magra 
produção escrita de Oswaldo Cruz, ressaltando, no entanto, os enormes aplausos com que fora recebida em todo o meio intelectual brasileiro do início do século XX. E para encerrar rapidamente tão controverso assunto, logo argumentou que Cruz teria sido simplesmente um vulto estudiosíssimo, pesquisador exato, experimentador rigoroso e perfeito observante das regras da investigação científica. Mencionou ainda que para o cientista francês Charles Richet, por exemplo, um dos ícones da admiração não só de Castro, mas de toda aquela geração, Cruz teria sido nada menos que o primeiro higienista dos tempos modernos! ${ }^{4}$ Portanto, quais portas não se abririam com honra à sua chegada?

No restante do discurso, Castro tratou das então recentes reformas na medicina quando da 'ascensão' dos métodos do laboratório, os quais teriam convertido por completo a antiga "arte do diagnóstico" em conhecimento científico e exato, substituindo ainda os famosos, mas "ineficazes", "olho médico", "tino médico" e "ouvido médico" pelas rigorosas "observação", "experimentação" e "previsão" das reações biológicas confirmadas pelo microscópio ('Discursos proferidos na Academia Brasileira', Revista Americana, n. 8, maio 1919, p. 120).

A posse de Aloísio de Castro foi igualmente saudada por Afrânio Peixoto, sempre destacado, por sua própria trajetória, para justificar as polêmicas eleições na Academia. No discurso de recepção ao sucessor de Oswaldo Cruz, Peixoto acusou de inveja e despeito os insistentes críticos dos 'cientistas' e médicos na ABL: "A quem não coube sequer uma vantagem na vida, como estranhar que aos outros não permitam tenham tantas?" ('Discursos proferidos na Academia Brasileira', Revista Americana, n. 8, maio 1919, p. 131). E em já conhecido posicionamento, argumentou que as letras não eram uma carreira profissional stricto sensu, como a ciência, ao contrário, o seria perfeitamente, sendo que valiam exatamente como diversão, adereço e livre inspiração. Afinal, eram 'arte', artifício; o que a ciência, linguagem da verdade, não poderia jamais pretender ser. E ainda acrescentou: no momento em que a literatura se estabelecesse como atividade lucrativa, como alguns dentre eles já pleiteavam, perderia justamente a sua nobreza estética. No mais, dizia não perceber por que somente aos médicos e cientistas a imprensa fazia "tão maus modos", já que todos os acadêmicos acabavam exercendo alguma segunda profissão. ${ }^{5}$ Eram também professores, juízes, militares, advogados, políticos, diplomatas ou funcionários públicos. E por que seu gosto efêmero e tendência literária 
não eram questionados, quando causavam verdadeiro furor se abraçados por um homem de ciência? ('Discursos proferidos na Academia Brasileira', Revista Americana, n. 8, maio 1919, p. 132-133).

Outro acadêmico, Medeiros e Albuquerque, partilhava rigorosamente da mesma opinião, dizendo não perceber porque um cientista-literato era considerado um "animal tão híbrido na fauna intelectual" daqueles tempos (Jornal do Comércio, out. 1923 - Arquivo Pessoal Afrânio Peixoto. Centro de Memória/ABL). No mais, assegurava não compreender tampouco a verdadeira sedição que se seguia quando um autor daqueles tempos 'atrevia-se' a se dedicar concomitantemente a duas especialidades diferentes. E ainda debochava do ceticismo com que veriam o talento polivalente de alguns, sustentando que do próprio Afrânio Peixoto, por exemplo, pensariam tratar-se na verdade de uma firma social, ou, quem sabe, de um pseudônimo para um grupo de homens de letras e de ciências interessados somente em fazer pilhéria com os demais. E essa sugestão amalucada faria sentido, no seu dizer, pois os partidários da especialização andavam tão convencidos de que 'profissão' e 'competência específica' andavam juntas que só poderiam mesmo duvidar da existência, em carne e osso, dos enciclopédicos (O Estado de S. Paulo, 17/12) 1919 - Arquivo Pessoal Afrânio Peixoto. Centro de Memória/ABL).

A essas hesitações de Peixoto e Albuquerque, pode-se contrapor, tal como se viu no capítulo anterior, todo o esforço que os 'cientistas' e os médicos, e só eles, faziam para libertar-se da influência englobadora da literatura e de todo resquício de cultura enciclopédica na sua atividade profissional. Não causa surpresa, portanto, que fossem pressionados a explicar tantas contradições. E elas, exatamente, não paravam de se suceder e se acumular. Os homens de ciência-acadêmicos chegaram ao ponto, inclusive, de engrossar o coro daqueles que criticavam a falta de critérios para o exercício da atividade literária. Aloísio de Castro, por exemplo, em comentário que à primeira vista poderia ser considerado uma piada dada à imensa quantidade de censuras que recebia, ele mesmo, por ser membro da ABL, indignou-se: “(...) e é pedantice de que muitos fazem estandarte. Com isto, se vestem de literatos e literatejam a seu talante e cômodo. Já não há distinções, todos se vêem tomados ao mesmo par (...). É tempo e mais que tempo de reagir contra essa desordem". Confusão toda que, no seu entender, deveria ser tributada na conta dos bacharéis que insistiam em se exibir nos meios intelectuais da cidade. Aliás, termo que na argumentação dos letrados da ocasião, já se sabe, funcionava como o sinônimo perfeito para os presumidos e enciclopédicos em geral. ${ }^{6}$ 
E quanto à admissão do próprio Castro na Academia era, por vezes, exaltada como bastante alvissareira, pois sendo aquela casa a do cultivo da língua e literatura no Brasil, quem sabe os cientistas não adquirissem finalmente certo brilho e polimento na escrita? Mas mesmo assim, com tanta beneficência de parte da instituição, Machado de Assis, o grande fundador da ABL, no dizer de certos pleiteadores a uma vaga na casa, estaria muito aborrecido, pois não caberia originalmente à instituição fazer caridade e sim premiar os talentosos das letras. No mais, já ele teria apregoado que a ciência era uma "má vizinha". Somados todos esses elementos, custava-lhes crer que pudessem se coadunar, numa só pessoa, a "fantasia" do poeta e a "atmosfera pesada" da realidade de um cientista ('Seção Academia Brasileira de Letras', Revista do Brasil, n. 50, fev. 1920, p. 163). Ou bem contemplariam uma flor por sua beleza, ou bem dela desconfiariam por poder vir a ser a mãe de um fruto venenosíssimo (Renato Almeida. 'Afrânio Peixoto Romancista, Revista do Brasil, n. 62, fev. 1921, p. 109). Suas diferenças residiriam, na verdade, nas distintas motivações e olhares que lançavam ao mundo. Em outras palavras, literatos seriam "homens de sensibilidade", e cientistas, de sua parte, seriam os "observadores desapaixonados das coisas" (Assis Chateaubriand. 'A palavra do professor Miguel Couto', O Jornal, 07/04/1927 - Arquivo Pessoal Miguel Couto. Centro de Memória/ABL). Não experimentariam grandes desesperos, tampouco intensos entusiasmos. Eram percebidos, definitivamente, como homens de objetividade e de incansável bom senso.

No caso de Castro, também membro da ANM desde 1904 e do Instituto Histórico e Geográfico Brasileiro (IHGB) desde 1911, mesmo a tão apregoada afeição pela leitura dos clássicos não funcionava sempre como passaporte suficiente para a degustação do, então, já afamado 'chá das cinco' dos acadêmicos. Na verdade, essa sua predileção acabava sendo conotada como "almofadismo literário e donzelesco", ou ainda como uma "aflitiva vaidade" por Castro querer "se mostrar" fora dos domínios da sua especialização. Como vemos, as críticas continuavam girando em torno da ambigüidade do seu duplo posicionamento como 'homem de ciência' e 'acadêmico'. Na suspeita dos seus censuradores, não era essa mesma geração que se propunha, afinal, a um rigoroso controle das competências intelectuais prestando-se ao papel de "verdadeiros guardas urbanos verificando a carteira de identidade dos falsos sábios", e batendo "com o martelo da sua fiscalização policial no ouro desses ídolos"? E se eram, como não 
cansavam eles mesmos de repetir, 'homens de ciência' como poderiam pretender ostentar uma cultura enciclopédica de modo a justificar o seu ingresso na ABL? (Menotti Del Picchia. 'O fenômeno Couto-Bichat', Correio Paulistano, 07/04/1927 - Arquivo Pessoal Miguel Couto. Centro de Memória/ABL).

No mais, naqueles 'tempos modernos' diversificados e velozes, que 'grande gênio' conseguiria dominar a totalidade dos conhecimentos humanos em todos os seus ramos? Tudo isso seria, no entender dos críticos à entrada dos médicos e cientistas na ABL, impossível, dada a efemeridade da vida, os imperativos do tempo e as limitações da inteligência humana ('A confusão das línguas numa epístola de Miguel Couto', Revista A.B.C., n. 631, 09/04/1927 - Arquivo Pessoal Miguel Couto. Centro de Memória/ ABL). Como poderia um mísero cérebro funcionar bem, em contínua aquisição de conhecimentos distantes, e ainda desdobrando-se em raciocínios de diferentes tipos?

Na ocasião, passava-se a acreditar que seria melhor profissional quem vivesse segundo as suas próprias tendências 'psicológicas', ou, em outras palavras, quem produzisse no âmbito de uma dada especialização. "Cada um no seu lugar e no seu meio" (Jaime Cardoso. 'Mas artista também', O País, 07/12/1928 - Arquivo Pessoal Miguel Couto. Centro de Memória/ $A B L$ ). Insistir na postura contrária (e esse argumento não era de modo algum estranho aos 'cientistas'), ou seja, no cultivo de vários domínios do saber, só daria provas de apego ao passado e ao atraso. E os críticos dos homens de ciência-acadêmicos ainda perguntavam: como chamar por outro nome que não o de 'atrasado' a quem simplesmente não acompanharia as diretrizes do seu tempo, atravancando o progresso em geral do restante do país? Como denominar quem agiria como um "conselheiro do Império, como um velho e revelho, como um fantasma longínquo e já há muito desaparecido deste mundo"? (Castro e Silva. 'Os acadêmicos', Gazeta, 06/ 05/1919 - Arquivo Pessoal Aloísio de Castro. Centro de Memória/ABL).

No dizer dos seus críticos, os médicos e os 'cientistas', ocupados em erradicar doenças e em observar costumes de microorganismos nos seus laboratórios, acabavam mesmo mostrando-se incompetentes, pois não conseguiriam curar a si mesmos do suposto vírus "sonetococcus"; "grave infecção" que os atingiria no orgulho, desenvolvendo neles grande presunção da expressão literária. E o resultado da moléstia seria catastrófico, uma vez que, na falta da vocação e do talento, seus romances, contos e 
poesias seriam todos feitos com um bisturi! E, quanto a isso, o desaforo não poderia ser maior. Como se não bastasse não tomar da 'arte' como uma finalidade superior de vida, mas como um lazer, como um passatempo displicente para amenizar-lhes o desfastio, ou pior, como um mero adorno para o seu prestígio social, era ainda de conhecimento público que se refeririam à 'arte da palavra', fora das rodas acadêmicas, com grandes superioridade e desprezo (Menotti Del Picchia. 'O fenômeno Couto-Bichat', Correio Paulistano, 07/04/1927 - Arquivo Pessoal Miguel Couto. Centro de Memória/ABL). E ainda questionavam: por que, afinal, tamanho desdém? No seu dizer, só poderia ser despeito pela sua falta total de engenho literário. Despreparo que os críticos julgavam confirmar-se a cada vez em que se metiam em cogitações sobre outras atividades profissionais que não a científica. Ou seja, sobretudo quando 'ousavam' fazer discursos ou poesias. Quanto a isso, as referências são numerosas, variadas e preciosas.

Miguel Couto, por exemplo, ao proclamar um curtíssimo elogio fúnebre do médico e professor Nascimento Gurgel em 1928, teria ignorado a obra e os feitos do outro para dedicar-se a desfilar mil e um adjetivos sobre o cadáver! Assim, segundo o relato de um anônimo jornalista, Couto teria sido muito econômico ao falar de Gurgel quando vivo, definindo-o simplesmente como "combativo e ardoroso". Morto, quantos qualificativos: "derribado, hirto, mudo e inânime". A seguir, teria citado Camões, "alma gentil que partiste tão cedo desta vida...", para ao fim bradar: "Pobre Gurgel!". Nesses termos, o jornalista apressou-se em alfinetar o suposto mau gosto de Couto ao argumentar: "Eis o que é a nossa literatura acadêmica. Se é assim que fala o vulto máximo da nossa ciência médica, membro da Academia de Letras, membro da Academia de Medicina, imagine-se o que vai por aí... Não se pode deixar de exclamar, como o próprio orador exclamara: Pobre Gurgel!" ('Pobre Gurgel! Como a oratória acadêmica lhe consagra a memória', A Notícia, 03/01/1928 - Arquivo Pessoal Miguel Couto. Centro de Memória/ABL).

Aloísio de Castro também recebera lá a sua dose de desmerecimento como literato. Chegou mesmo a ser acusado de plágio pelos seus poemas, o que, diga-se de uma vez, nunca se confirmou. ${ }^{7}$ Da pena do mordaz Benjamin Costallat, no entanto, não conseguiu se desembaraçar. Assegurando, ele também, que 'homens de letras' e 'homens de ciência' seriam tipos totalmente diferentes, Costallat dizia só perceber as motivações literárias de Castro remetendo-as às suas responsabilidades e preocupações de mé- 
dico. E tudo isso porque os seus poemas eram tão risíveis que só poderiam mesmo ser um preparado medicinal para facilitar a digestão e o bom humor dos cariocas. Para Costallat, Castro seria tão bom, mas tão bom humorista - quando pretendia ser tão simplesmente um literato -, que acabava por fazer uma concorrência muito desleal a ninguém menos que Procópio Ferreira. E, para o total desespero de Ferreira, pois nenhum outro chegaria à altura de Castro "no brilho da graça, e na boa e franca risada que ele sabe provocar como ninguém. Ele faz da arte do riso uma obraprima". Para ilustrar o que dizia, citou dois poemas de Castro contidos no livro Os Carmes, publicado em 1928:

Valsarino, valsa, valsa,

Mas o leque não me leves,

Não m'o arrebates da mão...

Em tuas passadas leves

Nos volteios desta valsa

Leva só... meu coração./

Valsa, valsa, valsarino,

Vida é baile, festa e amor.

Dou-te o lábio purpurino

Sou cálice aberto em flor.

[E segue a comentar o Costallat]: Não é delicioso? [...] Outra jóia de bom gosto e de elevado e primoroso estilo literário é a 'Visão Noturna'. Ei-la:

Uma noite (ai que noite aquela)

Batem-me à porta...

Abro aflito a janela.

[E Costallat conclui]: Vejam a ironia de Aloísio de Castro! Batem-lhe a porta, e ele abre a janela. Isso quer dizer que quando lhe baterem à janela, ele abrirá a porta! Não é uma charge deliciosa contra os porteiros incapazes e os fâmulos descuidados? Não é uma crítica muito fina à crise domiciliar? $[\ldots]$

No dizer de Costallat, com tantas boas piadas, Castro deveria ser consagrado não como literato, por ser rigorosamente péssimo como poeta, mas como "o grande mestre do humorismo nacional"; além, é claro, de médico eminente já que sua literatura não passaria, afinal, de uma boa dose de humorismo para regularizar as funções orgânicas dos habitantes da cidade! ${ }^{8}$ 
Ilustrativa imagem da longeva preponderância da literatura na produção intelectual brasileira, e do correspondente incômodo que causava, foi mencionada por Miguel Couto quando da sua posse na ABL em 1919. Couto comparou a literatura a uma rede policroma e atraente que, de tão bem urdida, tecia e prendia os intelectuais brasileiros nos seus largos domínios. E até para justificar a sua presença na casa dos literatos, dizia-se enredado ele também. Mas assegurava que dos seus fios entrelaçados, quase uma cilada, o teriam alcançado somente as linhas pretas, as das dores e das doenças, por isso se tinha tornado um médico. E cometendo enorme gafe, mas indicando, mais uma vez, a simultaneidade semântica entre 'literatura' e 'arte da palavra', confessou ter tido muitas dificuldades para compor o seu discurso de modo a contentar os literatos, atribulado como estava com muitas dúvidas sobre o quanto carregar a sua fala da "respectiva e necessária dose de retórica". Sua aflição só denota o quanto achava, e por isso a indiscrição, a retórica duvidosa. A comparação não agradou aos acadêmicos. No mais, tão singela revelação deixou transparecer o quanto conotava, como os demais intelectuais de formação médico-científica, a literatura como mero, mas obrigatório, penduricalho de frases sonoras, belas e sem qualquer grande utilidade ('Discursos proferidos na Academia Brasileira', Revista Americana, n. 10, jul. 1919, p. 102-103).

Depois dessas palavras, Mário de Alencar, num constrangido discurso de recepção, reconheceu que Couto era um "escritor fora da literatura e sem ambição literária", mas cuja legitimidade como acadêmico devia-se a "breves segundos de inspiração". Para exemplificá-los, citou uma carta íntima escrita por Couto, sem esclarecer a quem se destinava, mas, segundo ele, cheia de "graça, melancolia e rara cultura literária"! ("Discursos proferidos na Academia Brasileira', Revista Americana, n. 10, jul. 1919, p. 131-132). E o acanhamento de Alencar foi tão marcante que acabou sendo, inclusive, mencionado como um 'espetáculo' na imprensa do Rio de Janeiro: "E esse discurso foi uma satisfação para os que ainda pensam que a Academia pode viver, se não pela sua influência na literatura, ao menos pelas suas recepções" (Revista Nacional, jul. 1919 - Arquivo Pessoal Miguel Couto. Centro de Memória/ABL).

Mesmo antes da posse de Couto, o burburinho com a sua eleição para a 'Casa de Machado de Assis' tinha sido tão grande que o próprio Rui Barbosa, então presidente da Academia e orador originalmente escolhido para pronunciar o seu discurso de recepção, sentiu-se atingido. Melindrado pelas controvérsias, Barbosa resolveu renunciar não só ao discurso como 
ao próprio cargo de presidente da casa, alegando não ser ele tampouco um 'puro escritor de ficção', tal como vinham exigindo a imprensa e certa parte dos acadêmicos. Miguel Couto, de sua parte, alguns anos depois e aparentemente cansado de tantos maus julgamentos, confessou a sua falta de familiaridade com a instituição, explicando-a em função da sua especialização profissional: “(...) Sou apenas um médico insulado em sua profissão. Meteram-me uma vez como expoente (de quê?) na Academia de Letras onde não me sinto bem camuflado em literato (...)" (A Nação, 08/ 02/1933 - Arquivo Pessoal Miguel Couto. Centro de Memória/ABL).

Como se vê, a ABL vinha sendo acusada, e cada vez mais sistematicamente, tanto de ser muito acolhedora quanto por considerar a produção literária não como um requisito obrigatório de admissão, mas como uma "contingência facultativa a alguns homens de letras ociosos" (Antônio Leão Velloso. 'Miguel Couto', Correio da Manhã, 02/06/1919 - Arquivo Pessoal Miguel Couto. Centro de Memória/ABL). E toda essa grande gritaria poderia ter sido ainda mais sonora, pois, com a morte de Couto em 1934, Carlos Chagas foi seriamente cogitado para sucedê-lo na cadeira 40 da ABL. No entanto, não chegou a formalizar a sua candidatura por ter falecido ele também pouco tempo depois. Aliás, outro médico, Renato Kehl, também foi sugerido para a cadeira, alindando-se todo para a Academia. Alceu Amoroso Lima, eleito para a casa no ano seguinte, ficou com a vaga, arrefecendo, com isso, certos ânimos mais exaltados. ${ }^{9}$

Se o recurso à gloriosa tradição da Académie Française nem sempre funcionava a contento para explicar a presença de homens de ciência numa casa de literatos, até para a falta de produção literária buscavam justificativas. Qualificando essa exigência, aparentemente elementar, de "manifesto erro", Afonso Celso alegou, sem constranger-se por um minuto com a desproporção do argumento, que os críticos da ABL pensariam viver nos tempos bíblicos, quando os homens 'duravam' de 400 a 900 anos, tendo tempo suficiente para burilar e remoer e remexer nos seus textos! Em contraposição,

quantas celebridades oriundas de uma estrofe, de um dito, de um gesto! Há quem prefira um jardim a uma selva, uma flor a um canteiro. Os evangelhos formam tênues fascículos. Sócrates nada escreveu. Cristo escreveu uma única vez, na areia, e ignora-se o quê. O mais substancial discurso proferido na Terra, o que condensa o Cristianismo em sua infinita sublimidade, o Sermão da Montanha, não durou talvez, segundo o texto sagrado, vinte minutos, tal a sua divina concisão. ('Discursos proferidos na Academia Brasileira', Revista Americana, n. 11-12, ago.-set. 1917, p. 53-54) 
No mesmo sentido, mas em outra ocasião, o talento para a escrita foi totalmente amesquinhado para justificar a presença de médicos e 'cientistas' na ABL. No dizer de Mário de Alencar, "o escrever bem é condição fundamental (para ser admitido na Academia), mas não é tudo; e às vezes é demais" ('Discursos proferidos na Academia Brasileira', Revista Americana, n. 10, jul. 1919, p. 134). E essa tão corrente exigência no âmbito da atividade literária seria, do seu ponto de vista, nada mais do que um desvirtuamento das próprias letras, que, de uma forma de cultivo pessoal (tão próximas das humanidades), passaram a ser uma profissão. E não só isso. Ainda segundo Mário de Alencar, a exigência do entendimento da literatura como escrita de ficção tinha levado a uma verdadeira proliferação de receitas e exemplares, de moldes e fôrmas para a composição literária. E por todo esse prontuário tinha-se passado a medir as qualidades de um verdadeiro literato. Desse modo, o talento para 'a imaginação' teria se transfigurado numa norma imposta pelo 'mercado', pelo jornalismo, pelas casas editoras, resultando, enfim, num aleijão, num instrumento de venda a retalho e torvelinho intelectual que induzia à exagerada publicação de textos. E que, para completar, ainda estimularia a vil concorrência entre amigos e companheiros. Em outras palavras, Alencar afirmava que, ao admitirem homens de ciência na sua agremiação, os acadêmicos pretendiam, na verdade, romper com o mercenarismo intelectual, com a venda a varejo das idéias, com o mecanização do pensamento imposta pela imprensa, o maior algoz da 'liberalidade' da Academia. Por ser arte, a literatura demandaria tão-somente sinceridade e sensibilidade, além de odiar a reprodutibilidade do gênio criador e o pagamento pela beleza singular que oferecia, por puro contentamento ('Discursos proferidos na Academia Brasileira', Revista Americana, n. 10, jul. 1919, p. 135-136).

Tantos desentendimentos e hesitações explicam-se pelo fato de 'literatos' e 'cientistas' estarem empregando, concomitantemente, as mesmas palavras, mas com sentidos distintos ou justapostos. O que, ao fim, redundava numa ausência de consenso mútuo quanto aos atributos das suas respectivas atividades intelectuais e que, no mesmo movimento, seguiam se distanciando. E no meio das interseções semânticas que faziam da 'literatura' um sinônimo de cultivo do espírito, de lazer, de humanidades, instrução, ócio imaginativo, arte de ficção, arte de bem dizer, belas letras, retórica, técnica escrita, talento especial, ora um passatempo, ora uma profissão, os homens de ciência continuavam se desdobrando para explicar o seu desvelo com a ABL. 
Certo é que os homens de ciência-acadêmicos recebiam críticas por estarem representando papéis inadequados ao seu status público. Além disso, também parece claro que não percebiam a literatura como uma profissão, ou seja, de acordo com o seu mais 'novo' sentido, mas, antes, segundo a sua acepção mais antiga, como instrução geral. Na verdade, a meio caminho entre as duas significações, tomavam-na tão simplesmente como um 'deleite do espírito', como um anteparo às agruras da sua própria profissionalização. Tomada como um passatempo por quem adentrava no seu mais importante canal de consagração, essa representação da carreira literária só poderia mesmo suscitar ressentimento em quem, de fora, pleiteava a profissionalização e o reconhecimento de uma 'natural' vocação para as letras.

Os 'cientistas', de sua parte, caracterizavam a sua atividade, a sua mentalidade e a sua linguagem como completamente afastadas de todo esse universo da 'arte de bem dizer' e dos 'lógicos' 'diletantismo' e 'curiosidade' que, então, enxergavam em toda sorte de atividade intelectual que fugisse dos domínios da sua profissão. No entanto, não ignoravam o excelente impacto que a entrada na ABL suscitava nos rumos das suas carreiras, adensando o seu prestígio em nível nacional. Esse tipo de aporte institucional, somado à eleição para o IHGB e para a ANM, permitia-lhes mais espaço nos jornais e revistas, garantindo, ainda, aos olhos do público letrado, a certeza da qualidade da sua produção cultural.

Em contrapartida, a Academia não hesitava em aceitar a candidatura de grandes notáveis, a despeito de todas as reações que despertava dentro e fora da casa. Seu perfil original foi, assim, totalmente modificado de modo a receber grandes figuras da nacionalidade e a garantir mais investimentos públicos, cada vez melhores sedes e uma respeitada notoriedade aos olhos da sociedade e mesmo no estrangeiro. Como via de consagração, institucional e intelectual, era, ao fim, excelente para todos.

Assim, a ABL tornou-se uma instituição ocupada em receber intelectuais de diversas áreas, graças às prebendas, simbólicas, políticas e financeiras, que almejava abraçar ao tornar-se (tal como se transformou efetivamente) a mais reconhecida associação letrada do país. No mais, era mesmo foco de grandes tensões, pois promovia e incentivava a entrada de membros que, fora dos seus muros, defendiam a divisão do trabalho intelectual. E os entusiastas da especialização, na contradição das suas duplas filiações, a ela acometiam velozmente pelo prestígio social que proporcio- 
nava aos seus membros. No entanto, eram obrigados a calar-se diante das críticas que a imprensa lhes dirigia sem cessar. Na verdade, pareciam mais surdos que calados, já que, nos seus discursos de posse, sempre alegavam nobres justificativas e motivações para as suas provisórias investiduras.

Quanto à pluralidade dos vínculos, vozes e performances de homens tão afeitos à defesa de identidades fixas, nenhum deles pode ser mais interessante que Afrânio Peixoto. Ninguém mais que o eminente professor de higiene da Faculdade de Medicina do Rio de Janeiro defendia, concomitantemente, argumentos que, não raro, se excluíam por completo. Pedagogista, higienista, psicólogo, crítico e publicista, membro da ANM e do IHGB, o sucessor de Euclides da Cunha na cadeira n. 7 da ABL era conhecidíssimo no meio letrado da cidade por seu orgulhoso ceticismo (Arthur Motta. 'Academia Brasileira de Letras', Revista do Brasil, n. 55, jul. 1920, p. 253). O que em parte era usado para explicar, às vezes por ele mesmo, o seu ecletismo ou a sua dupla atuação de 'homem de ciência' e 'literato' ('Discurso de posse de Afrânio Peixoto'. Ata da quinta sessão ordinária de 26 de julho de 1919, Revista do IHGB, parte II, 1919, p. 501). Anos depois se autodefiniria como um profissional "amorfo" (Senna, 1996: 83). Para outros, na verdade, esse seu ceticismo não passaria de uma "falha de princípios" que esclarecia tanto a sua falta de firme orientação na vida quanto a sua errância pelos múltiplos caminhos do "labirinto das idéias" (Jackson de Figueiredo. 'Afrânio Peixoto', Revista do Brasil, n. 51, mar. 1920, p. 228). No IHGB, foi especialmente saudado, em 1919, por reunir aos atrativos de uma boa escrita certa orientação científica, "predicados que o Instituto estima e preza" ('Parecer favorável sobre a admissão de Afrânio Peixoto no IHGB'. Ata da segunda sessão ordinária de 24 de maio de 1919, Revista do IHGB, parte II, 1919, p. 343).

Afrânio Peixoto dizia muito se orgulhar dessa 'sua indecisão' intelectual por detestar os letrados que presumem muito de si mesmos, apresentando-se como autoridades máximas, porque especialistas, em determinados temas. E revelou ainda ser especialmente afortunado exatamente por sua irreverência. Nas suas palavras, “(...) O certo é, quanto mais me cresce o ceticismo, de tudo - das letras, da ciência, da arte - mais me cercam as blandícias e os afagos das faculdades, escolas e academias, dos que pontificam e se exalçam nesses templos daquelas divindades" ('Discurso de posse de Afrânio Peixoto'. Ata da quinta sessão ordinária de 26 de julho de 1919, Revista do IHGB, parte II, 1919, p. 502). E acreditava que a confusão era 
toda ela do meio intelectual daqueles tempos que não sabia a quem reputar qualidade, se aos generalistas, os "amantes da instrução, coisa de Brasil Antigo", ${ }^{10}$ ou se aos especialistas, modernos decerto, mas também uns "oradores medíocres, de discursos frios, sem calor e sem vida, escritos com uma secura horrível" ('Discurso de Afrânio Peixoto'. Ata da sessão especial de 16 de agosto de 1922, Revista do IHGB, parte II, 1922, p. 496 e 499).

Nem sempre blasé, e volta e meia bastante irritado, Afrânio Peixoto acabava atribuindo intenções escusas e pouco lisonjeiras aos insistentes críticos dos médicos e 'cientistas' na ABL. Defendendo os já tão difamados 'bacharéis' que, segundo ele, eram, na verdade, uns injustiçados, pois teriam dado ao Brasil grandes pensadores, enquanto os seus maiores reprovadores não passariam de uns analfabetos, alegava também que, dos quarenta membros da ABL naquela ocasião, somente uns dez teriam formação científica, constituindo então a ínfima minoria da casa. Na sua argumentação, não faria sentido a cobrança de fidelidade ao ideal da especialização intelectual já que ele não seria assim tão desrespeitado na agremiação. Ao menos, não tanto quanto se alardeava na imprensa. Do seu ponto de vista, tamanha agitação não passaria de cobiça por tantas remunerações acumuladas: “(...) os letrados que lá [na $A B L]$ não entram, sem dúvida prefeririam a Academia de Medicina, o Instituto dos Advogados, ou o Clube de Engenharia, se aí houvesse jetom" (Diário de Notícias, Porto Alegre, 21/02/1933 - Arquivo Pessoal Afrânio Peixoto. Centro de Memória/ABL).

No dizer de Afrânio Peixoto, tão numerosas críticas só não seriam mais freqüentes que as próprias candidaturas à Academia, declaradas sempre aos quatro ventos e mesmo quando sequer havia vagas disponíveis. Nem o obrigatório período de luto pela morte de um acadêmico era respeitado. Segundo o seu relato, antes mesmo de rezada a missa de sétimo dia, as cartas, telefonemas e cartões com pedidos de votos para a ABL já começavam a circular pela cidade, sobretudo por iniciativa daqueles que simulavam toda sorte de desprezo pela instituição. E no remate do mesmo Afrânio Peixoto, que não poderia deixar passar tão preciosa oportunidade para mais um dos seus mordazes comentários: "É, custa muito, sem dúvida, esperar uma semana a quem pretenda a imortalidade" ${ }^{11}$

Sem pretensões à eternidade, seguiam, no entanto, empenhando-se em justificar a sua entrada como 'cientistas', tal como se autodenominavam altivamente, numa casa de literatos. Roquette-Pinto, membro da ABL desde 
1927, no seu discurso de recepção a Miguel Ozório de Almeida na própria Academia, parecia aconselhar o amigo a ignorar as inevitáveis críticas que se seguiriam à sua posse: "Não vos preocupe mais a indagação dos nossos intuitos no caso da escolha feliz - um romance vive em toda a obra de ciência. (...) Nós somos muito mais felizes; além da Arte, a Ciência nos ampara". ${ }^{12}$

E quanto ao próprio Ozório, a despeito de toda sua tão alardeada dedicação à ciência como se viu no capítulo anterior, com prazer tomou posse, em 1935, na cadeira n. 22 da ABL. No seu discurso, e em rara imodéstia, justificou, como todos os seus pares o faziam, a entrada de um "legítimo homem de ciência" numa casa de literatos, exaltando ainda o cultivo da tradição na Academia que, na verdade, distribuiria verdadeiros "títulos de nobreza" a expoentes da cultura nacional. Mas não a uma nobreza dos direitos hereditários, e sim àquela dos direitos adquiridos pela comprovação da inteligência e do mérito profissional. Relatou também que a sua geração fora a primeira, no Brasil, a ter possibilidades de conferir à sua atividade intelectual "uma direção única, independente e definida". E mais, amoldou as suas idéias da especificidade da psicologia científica à sua entronização na casa, alegando que, na verdade, tal psicologia poderia ser "multiforme". Quanto à sua carreira de 'cientista', contou ter apresentado aos fisiologistas uma teoria matemática e físico-química tão perfeita e exata que poderia mesmo ser considerada por alguns, menos ciosos da divisão do trabalho intelectual, o resultado de uma imaginação excessiva. Mas não. Ele era, como sustentava, já se sabe, um verdadeiro homem de ciência, e para tanto já adivinhava as críticas que receberia pela sua admissão na Academia (Jornal do Comércio, 24/11/1935 - Arquivo Pessoal Miguel Ozório de Almeida. Centro de Memória/ABL).

No entanto, Ozório de Almeida se enganou redondamente no seu prognóstico. No adiantado do século XX, a sua eleição para a ABL, à diferença das anteriores, não causou qualquer comoção na imprensa da cidade. Nenhuma indignação, nenhuma crítica, nenhuma reclamação, nenhum deboche. Cortinas cerradas, luzes apagadas e teatro desmontado, público nenhum a ouvir as suas explicações. Afinal, críticos, homens de letras, literatos, bacharéis e doutores já sabiam quais eram os misteriosos atributos primordiais de um 'cientista'. Àquela altura, já começavam a se convencer do esoterismo da atividade científica e das distâncias que se estabeleciam irremediavelmente entre profissionais e leigos. Definitivamente, os tempos já eram outros. 


\section{Novos Roteiros para Novos Enredos}

O então presidente do IHGB, o Sr. Olegário Herculano D'Aquino e Castro, em referência a Tácito no seu 'Diálogo dos Oradores', resumiu as motivações de 'cultivo do espírito' que pautavam o encontro dos sábios nas associações letradas do Rio de Janeiro. Não deixou sequer de citar o clássico autor no original, ou seja, em latim. Fórmula mais perfeita impossível:

Que pode haver que mais deleite e arrebate as pessoas de alma nobre e esclarecido espírito, que recreiam-se com prazeres honestos, do que a freqüente companhia de homens ilustres?! Quid enim dulcius libero et ingenuo animo, ad voluptates honestas nato, quam videre plenam et frequentem domum suam splendidissimorum hominum? ('Discurso do Presidente do Instituto', Revista do IHGB, parte II, 1906, p. 479)

Na verdade, seria mais do que um prazer a 'nobre' companhia dos homens ilustrados. Era considerada como honrosa e lisonjeira, sumamente agradável e, inclusive, recomendável pela superioridade das suas qualidades morais e intelectuais. Sobretudo naquele "templo luminoso do amor às letras", tal como era o Instituto, e onde estariam reunidos os principais espíritos cultos, amadores ou cultores das belas-letras; em suma: as maiores glórias literárias de todo o Brasil. Ilustres reputações construídas de bons desejos, diligência nos estudos, muita constância, amor aos livros, e ainda do inebriado e grandioso ideal da bela expressão oral. Como na descrição do Sr. Herculano, um verdadeiro sábio seria um vulto isolado e um ser privilegiado, alguém que, arrebatado pela esclarecida e transcendente luz da razão, era levado a ser um verdadeiro "apóstolo da virtude". Dos seus lábios brotariam torrentes de poesia e eloqüência, e em si não poderia conter tantos préstimos. Tenderia constantemente, como que levado por uma força superior, a difundir entre os outros homens "o finíssimo perfume que lhe embalsama a inteligência". Vultos como eram, os espíritos ilustrados, dotados de aptidão pelas letras, professando a ciência e aspirando à sabedoria, sentiriam muita necessidade da comunicação intelectual. E como a erudição, ou a "dilatação da esfera dos seus conhecimentos", era a sua mais alta ambição, prezavam a permanente permuta de idéias e impressões, de forma a aperfeiçoar a opulência de sua instrução e de se porem a par dos princípios gerais de todos os ramos do conhecimento. O que não conseguiriam mesmo nas suas longas vigílias, anos a fio, junto aos livros. Era mister que também apreendessem informaçoes uns dos outros ('Discurso do Presidente do Instituto', Revista do IHGB, parte II, 1906, p. 481-482). 
Tal como na ABL, os sócios do IHGB faziam discursos quando eleitos, usando da invariável modéstia nas orações de posse e do tom laudatório na exaltação das glórias do recém-chegado. No Instituto, para ser admitido como sócio efetivo, o candidato deveria residir no Rio de Janeiro e apresentar trabalho em história, geografia ou etnografia do Brasil, inédito ou já publicado, mas que, de todo modo, certificasse a sua capacidade literária. E enquanto a ABL era um "salão de intelectuais bem educados" - exercendo 'benéfica influência' na cordialidade das relações literárias da cidade -, o IHGB - no dizer dos seus entusiastas e admiradores - seria a mais austera e venerável sociedade sábia de todo o Brasil ('Vida literária', Revista do Brasil, n. 63, mar. 1921, p. 270). E por ser a "mais compreensiva e a menos especializada", reunia o próprio centro espiritual da nacionalidade, gerando lições beneméritas para os brasileiros numa "incansável reflexão à meia sombra e num fecundo silêncio" ('Discurso de posse do Sr. Oliveira Vianna'. Ata da quinta sessão ordinária de 11 de outubro de 1924, Revista do IHGB, parte II, 1924, p. 438).

Agremiações de "investiduras análogas" compartilhariam com a ANM a honra de sustentarem juntas os cinco ramos mestres da cultura nacional - a literatura, a história, o direito, a medicina e a engenharia -, incentivando a troca de informações num período em que começava a se impor a divisão do trabalho intelectual. Ao reunirem 'homens de ciência', 'homens de arte', 'homens de letras', 'homens de guerra' e 'homens de Estado', só atestavam dar provas do quanto se interessavam pelo desenvolvimento intelectual do país ('Discurso de posse do Sr. Oliveira Vianna'. Ata da quinta sessão ordinária de 11 de outubro de 1924, Revista do IHGB, parte II, 1924, p. 446). O maior estímulo que ofereciam era o prestígio público de que gozavam os seus sócios, ainda que a ABL oferecesse rendimentos aos seus membros assíduos e o IHGB cobrasse contribuições anuais de seus sócios.

Nesse universo, as senhas de entrada giravam em torno do amor que se consagra aos estudos, das leituras que dilatam as esferas do conhecimento, da inteligência que só se robustece em "longas vigílias e afanosas diligências em procedentes investigações", da sabedoria como a "suprema aspiração das almas bem formadas" e do sábio como o amigo da instrução, "feliz em todas as idades, venerável em todos os tempos, glorioso e quase divino, em todos os séculos com pleno conhecimento de todas as ciências e o exercício constante da virtude" ('Discurso do Presidente do Instituto', Revista do IHGB, parte II, 
1906, p. 479-481). Nesse culto à inteligência fazia-se notar, sobretudo, a paixão pelos livros, aliados fidelíssimos, "sempre juntos de quem os ama, sempre fontes de consolação ou de alegria, os livros tanto deleitam o homem feliz, como suavizam as mágoas do que padece os embates da fortuna" ('Palavras do Dr. Ramiz Galvão'. Ata da sessão especial de 16 de agosto de 1922, Revista do IHGB, parte II, 1922, p. 501).

Esse era o ideal ilustrado que presidiu as associações literárias e científicas surgidas no Rio de Janeiro do século XVIII, como, por exemplo, a Academia Brasílica dos Esquecidos, a Academia dos Felizes, a Academia dos Seletos, a Academia Brasílica dos Renascidos, a Academia Científica do Rio de Janeiro e a Sociedade Literária do Rio de Janeiro. Nos seus hortos botânicos, bibliotecas, laboratórios químicos, observatórios astronômicos, jornais científicos e conferências públicas; seus associados, todos 'homens muito ilustres', admiravam as infinitas riquezas do país; eram naturalistas que perscrutavam os "segredos da criação divina", astrônomos ou "estudiosos dos movimentos siderais", artistas ou "extasiados dos movimentos da natureza", mecânicos e inventores, matemáticos e filósofos. Estudavam, enfim, desde o eclipse da lua ao calor da terra, passando por processos curativos, geometria, análise da água, danos e benefícios do uso da aguardente e métodos para extrair tinta do urucú (Max Fleuiss. 'As principais associações literárias e científicas do Brasil', Revista Americana, n. 11-12, ago.-set. 1917, p. 147-168).

Nos primeiros tempos republicanos, a ABL e o IHGB pareciam funcionar como o cadinho de resistência de toda essa sociabilidade cultural Ancien Régime - ilustrada, humanista e enciclopédica - recusando a especialização intelectual que se vinha impondo sob o manto da 'eficiência moderna'. Sociabilidade cuja motivação primordial era a de evocar o gosto particular pelas discussões letradas, salvaguardando (por serem a sua própria encarnação) a cultura nacional. Reuniam-se nessas associações tanto para estimular a convivência amigável por intermédio de sessões, reuniões, comemorações e efemérides, quanto pelo prazer de estarem juntos ouvindo e aprendendo, sempre mais, por intermédio dos resultados dos seus trabalhos em comum.

E médicos e 'cientistas' eram especialmente bem-vindos também no IHGB. Gozariam de imparcialidade, ânimo sereno e pleno domínio do assunto que estavam a professar. No mais, aquela geração de 'cientistas', particularmente, estaria honrando o nome do Brasil em séries de congressos 
internacionais e com publicações em revistas estrangeiras. Interessante é fazer notar que já começavam a ser reconhecidos intelectualmente por suas respectivas especialidades. Teriam mérito graças à sua firme decisão em não se apartarem dos domínios da ciência, cultivando certa fidelidade no trabalho, pois dela, afinal, provinha o seu renome ('Parecer da comissão de História para a admissão do dr. Juliano Moreira'. Ata da quarta sessão ordinária de 27 de julho de 1914, Revista do IHGB, parte II, 1914, p. 545).

Méritos reconhecidos, contradições justificadas, especialidades exaltadas. Henrique Morize, engenheiro, professor da Escola Politécnica, vicediretor do Observatório Astronômico, membro do Conselho Diretor do Clube de Engenharia e presidente da Academia Brasileira de Ciências (ABC), foi eleito para o IHGB em 1918, e muito educadamente desculpou-se, no seu discurso de posse, por não ter, como 'cientista' que era, dotes oratórios e grandes qualidades de expressão. Ausências rapidamente supridas no discurso de recepção feito a seguir pelo dr. Ramiz Galvão e nas séries de elogios que fez ao brilho dos predicados de Morize, em especial à sua inteligência, ao seu rigor, à sua austeridade e meticulosidade ('Discurso de recepção a Henrique Morize'. Ata da primeira sessão ordinária do ano de 1920, Revista do IHGB, parte II, 1920, p. 377, 390). Morize adentrou à casa para juntar-se a Roquette-Pinto, membro do IHGB desde 1913, e a Juliano Moreira, admitido como sócio em 1914.

Dois anos antes da eleição de Morize para o IHGB, ele se reuniu aos mesmos Roquette-Pinto e Juliano Moreira, ladeados ainda por Amoroso Costa, Oswaldo Cruz, Licínio Cardoso, Alberto Betim Paes Leme, Miguel Ozório de Almeida, Henrique Aragão, Arthur Moses, Álvaro Ozório de Almeida, Adolfo Lutz, Rangel Pestana, Bruno Lobo, Cândido Mello Leitão, Carlos Chagas, Frederico Carlos Hoehne, Parreiras Horta e Rodolfo von Ihering, dentre outros, para o fortalecimento de uma associação que concorresse para o desenvolvimento da ciência no Brasil segundo uma nova metodologia ('Da Sociedade e seus fins: estatutos da Sociedade Brasileira de Ciências', Revista da Sociedade Brasileira de Ciências, 1917, n. 1, p. 3). E assim fundaram e se tornaram membros da Sociedade Brasileira de Ciências em 1916, que, ao fim, passaria a se chamar Academia Brasileira de Ciências $(A B C)$ em $1921 .{ }^{13}$ Pretendiam não só discutir, mas formalizar e viabilizar a pesquisa em ciência pura, sem a obrigação da sua aplicabilidade imediata na indústria ou no comércio. Subdividida, a princípio, em seções de ciências matemáticas, ciências físico-químicas e ciências biológicas, 
incluía nos seus objetivos, de promoção da dedicação exclusiva à pesquisa no país, a organização de cursos e conferências de vulgarização e especialização científicas, a publicação de um periódico com os trabalhos dos seus sócios, e a instituição de prêmios e recompensas para trabalhos originais.

Na falta de uma universidade onde fosse possível o 'estudo imparcial da verdade', ou o desenvolvimento da 'ciência pura' como chamavam, a $\mathrm{ABC}$ instalou-se no prédio da Escola Politécnica do Rio de Janeiro, assumindo, pois, o encargo de auxiliar os seus sócios nas suas investigações científicas. Reunindo-se em comissões segundo as suas respectivas especialidades, grupos de membros passaram a discutir os assuntos ainda não estudados e os temas científicos a desenvolver, de modo a aprofundarem o conhecimento em áreas específicas do saber. Nos encontros dos membros da casa, que se reuniam separadamente segundo as seções, era expressa a prerrogativa de que só poderiam debater assuntos e questões científicas. Nas curtas atas das suas reuniões, vê-se que longos discursos não eram estimulados - a convivência dava-se em torno das leituras dos trabalhos de pesquisa, feitos nas suas instituições de origem, e onde estavam a comunicar aos pares os resultados das suas experiências ('Da Sociedade e seus fins. Estatutos da Sociedade Brasileira de Ciências'. Revista da Sociedade Brasileira de Ciências, 1917, n. 1, p. 3-10).

Nas atas também se pode verificar que os sócios eram empossados sem discursos de recepção, que, por sua vez, foram substituídos por breves saudações que poderiam ser feitas por qualquer outro membro da casa designado previamente pelo presidente. Novos sócios só poderiam ser eleitos quando obtivessem parecer favorável, pelas comissões das seções especiais, sobre a consistência dos seus trabalhos científicos, e sempre de acordo com os temas que desenvolviam nos seus locais de trabalho.

Dentre as questões especialmente debatidas na casa, nota-se a proeminência da teoria da relatividade de Einstein (que inclusive visitou a $A B C$ e nela proferiu uma palestra em maio de 1925) e da filosofia de Henri Poincaré, que, como já se viu no capítulo 5 , apregoava uma maior fixidez da terminologia e da linguagem científicas. Discutindo e aplicando esses novos paradigmas epistemológicos, formaram comissões incumbidas de redigir o Dicionário Técnico Científico Brasileiro, um malogrado esforço de organização das regras gerais da aplicação de conceitos e definições em cada ramo científico. Para tanto, foram criadas quatro subcomissões relativas às especiali- 
dades de física, química, geologia e mineralogia ('Resumos das atas das sessões', Revista da Sociedade Brasileira de Ciências, n. 4, 1920, p. 232; 'Ata da sessão de 18 de novembro de 1921', Revista de Ciências, n. 1, 1921, p. 94).

Além da discussão sobre a profissionalização da prática científica, debatiam também as fronteiras entre as áreas do conhecimento, o incentivo ao exercício de uma atividade permanente como um modo de vida, a exortação à realização de pesquisas sobre temas nacionais e a definição de novas áreas de atuação pública. O alcance desse argumento permite abordar tanto o aparecimento de um tipo especializado de profissional que se reconhecia e se autodenominava 'cientista' ${ }^{14}$ quanto a discussão sobre o novo papel a ser exercido pela ciência. E isto era claramente evidenciado entre os membros da $\mathrm{ABC}$. Reaparecem, assim, as intenções de consolidação do seu espaço de atuação profissional e a veiculação pública de suas atividades e trabalhos, relacionados, cada vez mais, às suas respectivas especialidades. Constantes eram, também, seus esforços pela criação de instituições de ensino superior nas décadas de 1910 e 1920. No seu desenho, as universidades deveriam ser os lugares por excelência do aprimoramento e especialização das elites intelectuais brasileiras, a sua vanguarda civilizatória. Nas suas análises e livros - principalmente os de Miguel Ozório de Almeida de sugestivos títulos, como A Vulgarização do Saber, Homens e Coisas de Ciência e A Mentalidade Científica no Brasil -, defendiam que um 'cientista' - leia-se um 'homem de ação' - se encontrava diante de três saberes fundamentais: a antropologia, a "eugenia" e a higiene, relacionadas, respectivamente, à herança, ao meio e à educação. Segundo eles, para influir na herança, era preciso criar um meio propício, ou seja, era preciso educar.

$\mathrm{Na}$ opinião desses 'cientistas' deveria ser efetivada uma mudança profunda no modo de ensinar no Brasil. E tudo isso porque à exceção do Instituto Oswaldo Cruz, todas as demais organizações superiores de ensino, como a Escola de Agricultura e Veterinária, e mesmo o Museu Nacional, o Jardim Botânico, o Observatório Nacional e o Instituto de Química, promoveriam um "estudo diluído e salteado". Segundo eles, esse tipo de educação precisava de pronto ser substituído por um sistema de instrução sucessiva, outorgando diplomas conforme o rígido e eficaz desempenho em exames freqüentes. No mais, pleiteavam o fim de um sistema de ensino que possibilitasse a aquisição de diplomas simultâneos em ciências e letras. Nada mais coerente, pois, além de todas as diferenças de espírito, mentalidade e aptidões, esses profissionais lidavam ainda com a pesquisa de espécies totalmente distintas de 
fenômenos. E no seu esquema mental, essa convicção funcionava como um verdadeiro axioma: para cada ordem fenomenal, um saber particular. Daí não só a distância entre ciência e literatura - a primeira ocupada com a 'utilidade da vida', a segunda com o 'encanto da vida' -, como ainda entre os próprios ramos do saber científico ('Manifesto ao Presidente da República: a Universidade do Rio de Janeiro e a criação da Faculdade de Ciências', Ciência e Educação, ano I, n. 2, mar. 1929, p. 3-4; Afrânio Peixoto. 'Comparações', Revista Americana, n. 7, abr. 1917, p. 26; Almeida: 1931: 158).

E a separação entre ciência e literatura deveria, sem demora, ser adotada, pois, em toda "ordem de existência superior" reinaria a complexidade dos fenômenos (Jonathas Serrano. 'Classificação das Ciências', Revista Americana, n. 8, maio 1917, p.83). ${ }^{15}$ Ou seja, 'sociedades mais desenvolvidas', ou mais modernas e civilizadas, exigiriam a divisão do trabalho intelectual. E como, na opinião dos aspirantes a especialistas, o Brasil já se teria desenvolvido bastante, fundamental era mesmo a diversificação das carreiras intelectuais. Para cada ciência especial, um conjunto de verdades da mesma ordem. Sucede daí, então, a necessidade da organização e hierarquização dos fenômenos segundo os diferentes tipos de ciência, como a matemática, a astronomia, a física, a química, a biologia e a sociologia. Tinham ainda a plena convicção de que as ciências se distinguiriam segundo as diferenças dos seus objetos de conhecimento. Para as ditas 'ciências naturais' caberia o estudo físico da natureza, do mundo, do universo enfim. Às ditas 'ciências sociais' pertenceriam o estudo do homem, da humanidade, da sociedade e da nacionalidade, assim como a disseminação da instrução entre os analfabetos, o saneamento e o povoamento do país e a seleção das raças. ${ }^{16}$ Seguindo essas classificações, pode-se ainda chegar às diferenças entre ciências 'objetivas', ou seja, matemáticas e físicas, e aquelas tidas como 'subjetivas', como a sociologia, a história, a psicologia, a economia e a política.

Essas classificações, no entanto, em nada interferiam na relação de um cientista com a verdade, pois em todas elas - gerais ou particulares, naturais ou sociais, objetivas ou subjetivas - deveria haver uma total conformação entre a hipótese do pesquisador e as evidências empíricas utilizadas. Toda essa divisão entre saberes seria útil, na verdade, como um esforço de "coordenação da inteligência", de modo que diferentes esferas do mundo físico e social ficassem sob o encargo de 'cientistas' especialmente preparados para analisar o seu respectivo tipo de objeto. A palavra de ordem era 'eficiência' (Jonathas Serrano. 'Classificação das Ciências', Revista Americana, n. 8, maio 1917, p. 90)! 
A defesa apaixonada da fundação das universidades explica-se pela associação que os 'cientistas' faziam entre educação superior e a promoção do progresso do Brasil. Em outras palavras, à intelectualidade brasileira, toda ela reunida em instituições com esforços congregados, caberia a avaliação e a direção da vida social, política, econômica e cultural do país, e esse seu papel só seria bem exercido com a criação das "casas de ciência", que fariam as elites repontar "da massa anônima como os cristais no seio das águas-mães". ${ }^{17}$

A rigor, mesmo antes da fundação da $A B C$, o primado da especialização começava a fazer frente aos loci da tradição intelectual Ancien Régime. Numa das reuniões extraordinárias do IHGB em 1911, os sócios Alberto de Seixas Martins Torres e Max Fleiuss, seu secretário perpétuo, propuseram que ao Instituto se juntassem a ABL, o Instituto da Ordem dos Advogados Brasileiros, o Clube de Engenharia, a Sociedade de Medicina e Cirurgia, o Centro Positivista, a Sociedade de Geografia, as congregações das faculdades e academias de ensino superior, bem como ainda a Sociedade Nacional de Agricultura, o Centro de Imprensa e os redatores chefes dos jornais e revistas da cidade para, em conjunto, fundarem a "Universidade Brasileira". Esta seria dividida primeiramente entre ciências e letras, e, mais a médio prazo, em quantos ramos pudesse ser dividido o conhecimento humano. Mas, com especial destaque ao "estudo prático da nossa terra e às idéias fundamentais da política nacional" ('Ata da sessão extraordinária de 26 de agosto de 1911', Revista do IHGB, parte II, 1911, p. 616-617).

A proposta, no entanto, foi rejeitada alguns meses depois, exatamente pelo pretenso excesso de "especialização intelectual" exigido para a sua fundação. Ao parecerista, dr. Viveiros de Castro, causou espécie esse encargo atribuído a uma instituição tradicionalmente "enciclopédica" como o IHGB, afastando-o totalmente da esfera habitual de sua atividade. Toda essa exaltação da especialização dos estudos e da técnica não poderia, pergunta ele, contribuir para a já tão decantada proeminência do "homem-braço" sobre o "homem-cérebro"? Dizia reconhecer a importância da fundação de uma instituição que regulasse a profissionalização intelectual, ampliando o acesso à educação superior, sobretudo num "país em que a leitura, à exceção feita dos jornais e de revistas apimentadas, ainda é objeto de luxo". Admitia igualmente que a divisão do trabalho cultural era o grande axioma da ciência, sendo a especialização a maior diretriz de todo o movimento intelectual mundial, por limitar, num só campo, o esforço 
de uma inteligência criadora, incapacitada de dominar o conjunto incessante de conquistas científicas daquele período. Mas não poderia configurar também, temia, uma debilitação do pensamento, impossibilitado de estabelecer relações entre ordens de fenômenos tornadas absolutamente distantes e inconciliáveis? ('Ata da primeira sessão ordinária de 23 de abril de 1912', Revista do IHGB, parte II, 1912, p. 234-239).

Fraqueza da inteligência ou método de trabalho adotado por aqueles que decidiram circunscrever o campo de sua atividade, pouco importa, a especialização intelectual seria, do seu ponto de vista, tão simplesmente uma traição aos ideais do IHGB, cuja largueza do programa vinha sendo orgulhosamente proclamada desde a sua fundação em 1838. Ou seja, o de receber os grandes eruditos e cultores das letras brasileiras, assim como ainda todos os grandes estudiosos dos problemas históricos, geográficos e etnográficos do Brasil. Ao rejeitar a proposta de "criar sábios a granel" como chamou, seu parecer contrário à fundação da Universidade foi aprovado com unanimidade pelos demais membros da instituição presentes então à reunião ('Ata da primeira sessão ordinária de 23 de abril de 1912', Revista do IHGB, parte II, 1912, p. 239).

Alguns anos depois, e com mais modéstia, o IHGB fundou a sua Escola de Altos Estudos, aplaudida por vários de seus membros, como Afonso Celso, então presidente do Instituto, Souza Pitanga, Ramiz Galvão, Roquette-Pinto, Oliveira Vianna, Rodrigo Otávio e Basílio de Magalhães, dentre outros. Oliveira Lima, o parecerista da proposta de criação da Escola, destacou que a douta corporação, "ninho da erudição" no Brasil, estava ampliando as suas atribuições, sem, no entanto, negar o plano basilar dos seus fundadores. A Escola de Altos Estudos, criada em 1915, serviria para transformar o próprio IHGB num "organismo mais complexo, mais vivaz e mais expansivo, consentâneo à cultura moderna no seu duplo caráter científico e literário" ('Ata da sexta sessão ordinária de 7 de setembro de 1916', Revista do IHGB, parte II, 1916, p. 767).

Até mesmo a mais enciclopédica das associações letradas brasileiras propunha a criação de um centro de ensino onde o currículo atendesse à norma da especialização entre ciência e literatura. Aliás, regra básica da cultura contemporânea, atendendo inclusive às demandas do mundo moderno ao "dotar(em) com caráter ativo o grande repositório de saber passivo a seu cargo". O parecerista reconhecia em Fleiuss, mais uma vez, a diligência para a criação da Escola. Naqueles últimos anos, Fleiuss vinha insistindo que o Instituto tinha as melhores condições morais e um admirável 
quadro de professores dispostos a fazer germinar a pesquisa original e individual em ciências, tal como os franceses já desenvolviam e ensinavam nas suas escolas e cursos de especialização ('Ata da sexta sessão ordinária de 7 de setembro de 1916', Revista do IHGB, parte II, 1916, p. 768-770). Quanto mais não seja, sustentava que a Escola de Altos Estudos equipararia o IHGB, em função, perfil, produtividade e fama, senão ao Institut de France, ao menos a Sorbonne! Que outro argumento poderia fazer frente à tal empreitada? (Max Fleuiss. 'As principais associações literárias e científicas do Brasil', Revista Americana, n. 11-12, ago.-set. 1917, p. 168).

Surpreendente, mas não desatinado, o projeto proposto pelo IHGB não pretendia descurar de todo da formação espiritual dos seus alunos, ainda que privilegiasse os estudos de caráter científico. Parecerista, promotor e entusiastas concordavam que as humanidades vinham sendo injustiçadas no país, eclipsadas na verdade, e isso numa terra em que já tinham gozado do mais honroso cultivo e reputação. Latinistas, helenistas, puristas do vernáculo e grandes sábios padeceriam, então, de tantos preconceitos que, no dizer de Oliveira Lima, "se debandaram espavoridos diante dos repetidos e cruéis atentados" contra as suas preferências intelectuais. Pois então, no programa ideado para a Escola, privilegiaram também o estudo da língua, das letras e da filosofia, ainda que tenha sido planejada primordialmente para aqueles que "freqüentam um terreiro de ação útil", ou seja, os 'cientistas' ('Ata da sexta sessão ordinária de 7 de setembro de 1916', Revista do IHGB, parte II, 1916, p. 770-772).

Essas searas, no entanto, não seriam confundidas e nem seus respectivos alunos associados no interior da Escola. Reconheciam o tributo da Instituição à "filosofia do século XVIII habituada às generalizações", mas sentiam a necessidade de se adaptarem aos novos tempos, nos quais a vida em comum tinha fins e necessidades diversas; e tudo isto porque "a particularização é(ra) realmente uma necessidade da inteligência contemporânea" ('Ata da sexta sessão ordinária de 7 de setembro de 1916', Revista do IHGB, parte II, 1916, p. 772). Nos anos seguintes, a Escola promoveria cursos educativos ajustados ao perfil ilustrado do IHGB. Em 1919, transformou-se em uma Faculdade de Filosofia e Letras que passaria a oferecer os cursos de filosofia e letras, ciências políticas e sociais, e o curso normal superior.

Em 1920, 'cientistas' e intelectuais regozijaram-se finalmente pela criação da Universidade do Rio de Janeiro. A sua fundação parecia-lhes o 
coroamento dos seus esforços e a culminância do seu prestígio. Daí em diante, acreditavam, não estariam mais dispersos em várias sociedades e academias de caráter geral, mas reunidos em uma só corporação, com leis uniformes, com um só sistema pedagógico e didático, um só plano de atividades, usufruindo o reconhecimento público pelo produto do seu trabalho. O que lhes parecia mais promissor com o aparecimento da Universidade era, além da possibilidade de oferecer preparo profundo para o exercício de certas profissões, a diversificação da produção intelectual no Brasil. Justificavam seu contentamento porque, até então, os médicos, os bacharéis em direito, os engenheiros e os mestres do ensino superior seriam praticamente todos polivalentes e autodidatas, aprendendo, ensinando e exercendo letras e ciências em conjunto, de acordo com as suas preferências pessoais. E essa confusão entre os dois ramos do saber adviria, do seu ponto de vista, da falta de universidades no Brasil - insuficiência a ser sanada pela formação de profissionais específicos para as diversas carreiras, a começar pelas de letras, de um lado, e de ciências, de outro (Afrânio Peixoto. 'O regime universitário e a educação nacional', Revista do Brasil, n. 65, maio 1921, p. 158-161). Quanto mais não seja, cumpria-lhes o estudo das 'coisas próprias do Brasil', sua geologia, sua geografia, sua climatologia, flora, fauna, etnografia, parasitologia, medicina, higiene, sociologia. E onde mais poderiam ser estudadas, nas suas particularidades e com consistência e profundidade, senão numa universidade brasileira? Incitando o ensino profissional, promovendo a pesquisa experimental em cursos variados de aperfeiçoamento, a universidade constituir-se-ia na grande "oficina espiritual da nação" (Afrânio Peixoto. 'O regime universitário e a educação nacional', Revista do Brasil, n. 65, maio de 1921, p. 163).

Por tudo isso, lamentaram, ao fim, a falta de uma faculdade de ciências na universidade recém-criada. E a reação logo se faria sentir. Nas reuniões realizadas em outubro de 1926 na Associação Brasileira de Educação (ABE), discutiram sistematicamente o projeto de criação da Faculdade de Ciências do Rio de Janeiro. ${ }^{18}$ A ABE foi fundada em 1924 por vários membros da própria Academia de Ciências com o intuito de fortalecer sua luta pela reforma educacional no Brasil. Nas atas das reuniões da Associação, que promovia desde cursos de especialização em ciências a conferências populares de vulgarização científica, vemos que as discussões dos seus membros faziam eco às reivindicações dos membros da $A B C$. 
Na faculdade de ciências que idealizavam, visavam promover a iniciação técnica em laboratórios e observatórios, excursões científicas e viagens de exploração, e, por fim, 'pesquisas científicas originais' em temas nacionais. Seus recursos adviriam do Estado, de donativos de particulares e de associações de ciência. Suas seções de ensino e pesquisa foram divididas em ciências matemáticas, ciências físicas e químicas, ciências biológicas, ciências sociais (aí incluídas a etnografia, a geopolítica, a demografia), a economia social e a filosofia, subdividida em filosofia da ciência, estética, lógica e psicologia.

De todo modo, nada se fez, e no ano seguinte, em 1927, os membros da seção de ensino técnico e superior da ABE, com destaque para Amoroso Costa, Álvaro Ozório, Branca Fialho, Arthur Moses, Ferdinand Laboriau, Mário Britto, André Dreyfus e Arnaldo Rocha, continuavam exigindo a criação da faculdade de ciências. Por sua pressão, o então ministro da Justiça e Negócios Interiores, Augusto Viana do Castelo, empenhou a sua palavra, garantindo que seria logo instalada, ainda que provisoriamente, no edifício da Faculdade de Medicina do Rio. O ministro também prometeu que, depois de criada, a tão almejada faculdade de ciências seria rapidamente transferida para um novo edifício, com instalações mais adequadas, a ser construído junto ao Hospital das Clínicas, sendo que à $A B E$ e aos seus membros, em diálogo com a $\mathrm{ABC}$, caberia todo o seu plano pedagógico e didático. ${ }^{19}$

Por conta desse acerto, montaram-se comissões com especiais encarregados - já familiarizados por contatos ou passagens por instituições estrangeiras - de relatar suas experiências, pesquisar e trazer novos elementos que pudessem ajudar a organizar os estatutos, divisões e departamentos da nova faculdade. Álvaro Ozório, por exemplo, ocupou-se da Sorbonne e da Universidade de Paris, enquanto Arthur Moses dedicou-se às universidades inglesas, alemãs e americanas. ${ }^{20}$ Após as pesquisas, acordaram que a nova instituição, para efetuar-se sem deixar de atender aos seus anseios de especialização e profissionalização em pesquisas científicas, poderia ser, a princípio, mais modesta que a do projeto anterior de 1926. Na nova proposta, ofereceria os seguintes cursos e cadeiras: no curso de matemática, cálculo diferencial e integral, cálculo das variações, matemática superior, teoria das funções, geometria analítica, geometria projetiva, mecânica, cálculo das probabilidades e suas aplicações, física matemática, mecânica celeste, geodésia e geofísica; no curso de física e química, física experimental, químico-física, química mineral, química 
orgânica, química biológica, geologia, mineralogia; e no curso de biologia, anatomia comparada, fisiologia, zoologia (vertebrados), zoologia (invertebrados), embriologia geral, antropologia, etnografia, botânica, fisiologia vegetal e oceanografia.

No entanto, a redução dos cursos a serem oferecidos, com destaque para a subtração das ciências sociais, da economia social e da filosofia, não fez com que a proposta saísse do papel, e, ainda em 1929, os 'cientistas' continuavam a clamar pela mesma faculdade de ciências. Em manifesto ao presidente da República, publicado na revista Ciência e Educação, Henrique Morize, Juliano Moreira, Miguel Ozório, Roquette-Pinto e Mário de Souza, em nome da $A B C$, persistiam a reclamar da ausência de um estabelecimento de ensino superior no Brasil onde se realizasse a "pesquisa de problemas novos e das questões (nacionais) ainda não resolvidas" ('Manifesto ao Presidente da República: a Universidade do Rio de Janeiro e a criação da Faculdade de Ciências', Ciência e Educação, n. 2, mar. 1929, p. 3). E somente com a sua criação seria possível, no seu dizer, a ampliação dos trabalhos especializados, posto que, o Museu Nacional, por exemplo, entre as poucas instituições científicas existentes, limitava-se apenas a algumas ciências naturais. E sendo a ciência o estudo dos fenômenos naturais e sociais, mas, sobretudo, 'a vitória do homem sobre a natureza', urgia desenvolvê-la e pesquisá-la em todos os seus ramos. O que valia mais, no caso, era a própria promoção do espírito científico no país, por dar aos seus profissionais um novo sentido de iniciativa nas suas pesquisas e por restringir seus estudos às necessidades do Brasil e da época.

Depois de tantas diligências, só veriam universidades ajustadas ao seu gosto especializado na década de 1930 - a Universidade de São Paulo (USP) foi criada em 1934 e a Universidade do Distrito Federal (UDF) em 1935.

\section{As Interfaces entre a Especialização e a Divulgação Científicas}

Na Europa, sobretudo na França, a especialização científica caminhou de par com a divulgação popular dos seus cânones e procedimentos. Em outras palavras, com o insulamento da especialização científica nas altas esferas de produção do conhecimento, a divulgação da ciência ganhou maior espaço nos cursos e conferências populares, nas projeções de imagens e nos museus, nas fotografias e gravuras das revistas ilustradas e nas inúmeras atrações das exposições universais que varriam todo o 
Velho Continente na ocasião. Nesse período, vulgarização e especialização eram contrários indissociáveis no universo científico.

Condição primordial da vulgarização, a convicção na utilidade social da ciência levava a mobilizar recursos, a convencer do fragoroso progresso do qual seria a portadora, e, sobretudo, a instruir. Recreativo e didático, o primado da vulgarização científica na virada do século XX era o de falar aos olhos e aos ouvidos numa educação antes 'sensível' que livresca. No lugar de estudos nos livros, que demandavam disciplina e longa assiduidade, curtas palestras e imagens, transmitindo, em poucas horas, conhecimentos elementares; totalmente adaptados, aliás, a um tempo cujas palavras de ordem eram 'movimento' e 'novidade'. Misto de utilitarismo e vocação pedagógica, de concisão e clareza no discurso oral, de distração inteligente e didatismo das imagens, de encenações teatrais e narrativas anedóticas, de máquinas em funcionamento e interatividade, a vulgarização fortaleceu-se da conjunção entre o espetacular e o inédito, sem esquecer ainda da legitimidade da sua aura edificante - tanto para os que ensinavam quanto para os que aprendiam (Béguet, 1990; Sheets-Pyenson, 1985; Pestre, 1987).

No Brasil, assim como na Europa, a vulgarização e a especialização científica coincidiram historicamente, mas enquanto no Velho Continente os personagens envolvidos nas duas atividades pouco se confundiram, restringindo-se a especialização aos profissionais institucionalizados e alargandose a vulgarização com a popularidade das revistas grande público, no Brasil, seus personagens foram os mesmos, vários deles passeando pelos dois gêneros do discurso científico. Certo é, no entanto, que fizeram a defesa de cada uma dessas searas em suportes e veículos diferentes - na defesa da especialização e da profissionalização da atividade científica, priorizaram, como já se viu, as revistas de ciências e letras do período; para o ensino popular da ciência, fizeram uso dos jornais, de revistas de vulgarização científica, assim como organizaram palestras e conferências abertas ao público, de modo a popularizar informações e suas pesquisas sobre o país. Mais especial foi, entretanto, o uso de um instrumento de extraordinário alcance e de um ineditismo sem par como recurso educativo no Brasil - o rádio.

$\mathrm{Na}$ origem das duas atividades e reunindo tais personagens, a mesma convicção na ciência e que aqui fez nascer a ABC. E se da Academia, saíram, como acabamos de ver, importantes debates e idéias para a fundação de universidades no Brasil, dela também se originou a primeira estação radiofônica do país, pensada para ser tão simplesmente 'o livro dos que não sabiam ler'. 
À semelhança do que ocorrera na Europa na virada do século XX, no Brasil das décadas de 1910 e 1920, a defesa da especialização científica teve como correlato mais imediato a necessidade da 'tradução popular' dos conhecimentos que se iam tornando cada vez mais inacessíveis. E a divulgação da atividade científica preocupava, em especial, os membros da Academia de Ciências, sobretudo os que assumiam o seu tributo às idéias de Comte. Uma das premissas básicas do positivismo era a da puerilidade do 'povo' (Barros, 1986). No entender dos positivistas, as aspirações populares não se desenvolveriam sem auxílio e direção; na verdade, elas deveriam ser criadas e incentivadas por intermédio da exposição de modelos. Guiando o povo e indicando-lhe o bom caminho, os positivistas acreditavam contribuir de sua parte para o engrandecimento moral e progresso material de todo o país (Lima \& Sá, 2005).

E eles, mais especialmente, destacavam a importância de se divulgar, o mais amplamente possível, os conhecimentos obtidos através dos procedimentos científicos. Segundo eles, difundir a ciência corresponderia a estimular a inteligência dos brasileiros, criando uma nova mentalidade, mais coletiva e organizada. E esse espírito coletivo só poderia ser forjado se fossem estudados, debatidos e conhecidos os elementos de identidade e unidade entre os brasileiros (Moreira \& Massarani, 2001, 2003). Para tanto, estimulados por Roquette-Pinto, outros membros da $A B C$, Henrique Morize à frente, se empenharam num movimento que supunham como de alto amor patriótico, destinado ao estudo e à propaganda das ciências e temas próprios do Brasil. Sendo assim, em 20 de abril de 1923, fundaram a Rádio Sociedade do Rio de Janeiro, atual Rádio MEC, na sede da ABC na Escola Politécnica.

A rádio, uma idéia de Roquette-Pinto, foi projetada para ser uma verdadeira 'escola', propagando ciência e cultura entre todos os brasileiros analfabetos. Melhor dizendo, foi criada para ser um meio de educação popular, irradiando concertos musicais, notícias gerais e cursos de inglês, francês, história, literatura e ciências. Nas palavras de Roquette-Pinto,

(...) Rádio é o jornal de quem não sabe ler; é o mestre de quem não pode ir à escola; é o divertimento gratuito do pobre; é o animador de novas esperanças; o consolador dos enfermos; o guia dos sãos, desde que realizado com espírito altruísta e elevado. Viver no sertão não é mais morrer em vida (...). (Elétron, ano I, n. 4, mar. 1926, p. 1.) 
Roquette-Pinto e seus colegas da Academia de Ciências escreviam, montavam e apresentavam os programas radiofônicos. Davam as aulas transmitidas pela rádio, recitavam poesias, cantavam e tocavam piano. Roquette-Pinto escrevia e apresentava o "Jornal da Manhã"; preparava resumos de peças teatrais como Romeu e Julieta e Tristão e Isolda, assim como os comentários musicais para as óperas irradiadas na rádio, como a Traviata, Aída, O Barbeiro de Sevilha e Madame Buterfly; além de também redigir os textos para a "Hora Infantil", cujos temas, científicos, mas em linguagem acessível, eram: por que são verdes as folhas? Porque não vemos o ar? De onde vem o perfume das flores? Se a Terra gira por que não somos atirados para longe? O que é o arco-íris? Por que as estrelas só aparecem à noite? (Lima \& Sá, 2005).

Entre os cursos e palestras de divulgação científica emitidas pela rádio, podem-se citar, por exemplo, "Higiene", de Sebastião Barroso; "Estados físicos da matéria" e "Como nascem os rios", de Othon Leonardos; "Marés", de Mauricio Joppert; "Química", de Mário Saraiva; "Física", de Francisco Venâncio Filho; "Fisiologia do sono" e "A função educadora dos museus", de Roquette-Pinto; "Estudos sobre o metabolismo", de Álvaro Ozório de Almeida; "A siderurgia", de Ferdinand Laboriau; "A física e a vida moderna", de Dulcídio Pereira; "Geologia do petróleo", de Eusébio de Oliveira; "Teorias do acaso", de Tobias Moscoso; "A regulação nervosa da respiração", de Miguel Ozório de Almeida; "A indeterminação em matemática", de Ignácio Azevedo do Amaral; "Elementos de filosofia médica", de Fernando de Magalhães; "Geopolítica do Brasil", de Everardo Backheuser; "A fisionomia", de Fróes da Fonseca; "As populações asianas", de Alberto Childe; e "Migração na América", de Heloísa Alberto Torres (Boletim da ABE, n. 9, 1927, p. 6).

A transmissão do som por meio da telegrafia sem fio e de ondas eletromagnéticas parecia, a esses vulgarizadores de ciência, fazer congregar 'descobertas científicas', 'instrução da população brasileira' e 'inclusão social'. E essa associação entre radiotelefonia e educação não deixou de surpreender até mesmo Albert Einstein em viagem ao Brasil em 1925, quando elogiou "os esplêndidos resultados a que chegou a ciência aliada à técnica na difusão da civilização" no Brasil (Elétron, n. 6, abr. 1926, p. 3).

Um ligeiro comentário de Roquette-Pinto nos permite estimar os seus ideais de incorporação social por intermédio dos programas difundidos pela Rádio Sociedade: 
Creio que o Brasil tem hoje cerca de 30 mil lares providos de aparelhos receptores. Cada receptor serve, em média, a meia dúzia de pessoas. Porque, no interior, pelas provas que possuo, cada alto-falante é rodeado pela população da vila ou da fazenda. Há, portanto, umas 150 mil pessoas que ouvem diariamente as nossas lições, conferências, música, História do Brasil, Higiene, conselhos úteis à agricultura, notícias cambiais e comerciais, notas de ciência etc. Se muitos dos ouvintes são pessoas cultas para as quais aquilo é passatempo, alguns milheiros são homens e mulheres do povo que, sem saber ler, vão aprendendo um pouco. Temos tudo feito? Que esperança! Estamos apenas no início do começo... (Roquette-Pinto, 1927: 236)

Para Roquette-Pinto, as emissões radiofônicas, cobrindo todo o território nacional, seriam verdadeiros "centros de educação popular, irradiando para edificação, deleite e instrução da população rural, os conselhos da ciência, as notícias da história nacional, a poesia e a música" (Rádio, n. 19, jul. 1924, p. 10).

No entanto, a despeito de todo o seu entusiasmo, o rádio educativo, já nos anos 1930, não pôde concorrer com o enorme impacto que a música popular ganhou com a criação da Rádio Nacional e dos programas de auditório. Insistindo nas óperas e conferências, os 'cientistas' viam proliferar charges nas revistas e jornais, assim como correspondências de ouvintes reclamando dos programas "maçantes e cacetes" que a rádio emitia. ${ }^{21}$ Nas charges, homens e mulheres desesperados tampavam os ouvidos e saíam correndo, desembestados, ao menor sinal das emissões radiofônicas educativas, insistindo que, na verdade, só queriam diversão sob o som de 'no tabuleiro da baiana tem...' (Careta, 30/07/1933 apud Saliba, 2002; O Carioca, 16/11/1935 apud Saliba, 2002). Noutras, os próprios aparelhos de rádio tampavam os ouvidos, e muitas caricaturas ratificavam que os pretensamente 'metidos a cultos' sintonizavam a Rádio Sociedade tãosomente quando recebiam visitas, quando, escondidos, seriam os mais assíduos ouvintes das ditas rádios de música popular (Careta, 05/08/1933 apud Saliba, 2002).

Ainda assim, os cientistas-divulgadores continuaram a discutir meios e formas de educação científica. Roquette-Pinto, por exemplo, insistiu no rádio, e, com o auxílio da prefeitura do Rio de Janeiro, fundou, em 1934, a Rádio Escola Municipal, depois Rádio Roquette-Pinto. Os programas irradiados nesta emissora foram pensados como um complemento aos cursos das escolas primárias e aos cursos supletivos para adultos, destinando ainda parte da sua programação aos professores com sugestões para aulas 
de ciências, letras e artes. Como diretor do Museu Nacional, cargo que ocupou de 1926 a 1935, Roquette-Pinto fundou ainda o Serviço de Assistência ao Ensino de História Natural e a filmoteca da instituição, com farta exibição de guias, quadros didáticos e slides, tentando fazer dela um museu escolar. Para ele, o museu deveria ser "a universidade do povo" (Jornal do Brasil, 07/02/1953 - Arquivo Pessoal Edgard Roquette-Pinto. Centro de Memória/ABL). Participou ainda da criação das revistas de vulgarização científica Rádio, Elétron e Revista Nacional de Educação. Esta, uma publicação do Museu Nacional, tinha como lema: 'Em todos os lares, o conforto moral da ciência e da arte'. Distribuída gratuitamente pelas escolas, trazia muitas ilustrações e textos informativos sobre ciência e literatura brasileiras (Duarte, 2004). Além de Roquette-Pinto, outros 'cientistas' do Museu Nacional também se empenhavam na divulgação e no ensino de ciências, com destaque para Alberto Childe, Cândido de Mello Leitão, Heloísa Alberto Torres e Alberto Betim Paes Leme.

Em 1936, Roquette-Pinto criou e passou a dirigir o Instituto Nacional de Cinema Educativo (Ince). Sob a sua direção, o Ince produziu e distribuiu nas escolas filmes que encenaram, dentre outros temas, descobertas científicas, vultos e cidades históricas, noções de higiene, biologia, física, química, zoologia, botânica, geografia, astronomia, esportes, história do Brasil, literatura e música (Schvarzman, 2004). Segundo Roquette-Pinto e outros educadores brasileiros, como Lourenço Filho, Fernando de Azevedo, Anísio Teixeira e Francisco Venâncio Filho, o cinema, além de contribuir para a democratização e a modernização da educação no Brasil, também funcionaria como um auxiliar dos professores em sala de aula. Assim, com filmes curtos e em linguagem acessível, o Ince promovia o ensino de ciências em escolas de todo o país (Lima \& Sá, 2005). No seu entender, a educação popular seria mais eficaz se aproveitasse as imagens em movimento para divertir e, ao mesmo tempo, ensinar. O cinema, como dizia Roquette-Pinto, era o "irmão mais moço do livro". ${ }^{22}$

O mesmo Roquette-Pinto, já nos últimos anos da sua vida, de 1951 a 1953, colaborou com a prefeitura do Rio na condição de consultor do Departamento de Difusão Cultural. Neste departamento, sugeriu exposições, concertos ao ar livre, espetáculos teatrais, feiras de ciências, concursos de poesia e de desenho, passeios e visitas a bibliotecas, a instituições com valor histórico, a associações culturais e a clubes esportivos (Revista de Educação Pública, n. 33-40, jan.-dez., 1951-1952). 
Como se vê, projetos de reforma educacional congregavam boa parte da intelectualidade brasileira desde os anos 1910 e 1920. E se a reforma incluía a defesa irrestrita da dedicação exclusiva à 'ciência pura' e da profissionalização da carreira científica por intermédio da criação de universidades, não seria completa se não contemplasse também a promoção da educação popular. No discurso dos cientistas-divulgadores, a divulgação científica não seria apenas um instrumento de estímulo a vocações científicas, como na Europa, mas, sobretudo um meio de inclusão social. Na verdade, intentava-se que as 'complicações científicas' se incorporassem à vida cotidiana dos brasileiros através de textos fáceis e com o uso de sons e imagens. Mais precisamente, a ciência deveria ser utilizada para auxiliar a queda dos altíssimos níveis de analfabetismo e para a melhoria das precárias condições de vida, trabalho e saúde de um país que, além de marcado por baixíssima densidade demográfica, sobretudo nos meios rurais, era, desde a década de 1910, caracterizado como 'um imenso hospital' (Lima \& Hochman, 1996; Hochman, 1998; Lima, 1999). Ademais, a popularização dos conhecimentos científicos deveria ajudar também a desenvolver o amor dos brasileiros pela sua própria terra, história e tradições e a promover a democratização do acesso à alta cultura, aí incluídas música clássica, teatro e literatura universal. E à semelhança da divulgação científica realizada na Europa, o segredo da empreitada, levada a cabo principalmente pelos membros da Academia de Ciências, era o de educar divertindo. Os 'cientistas' dessa geração agiram em duas frentes - ciência pura e ciência popular - e mudaram o panorama intelectual brasileiro das décadas seguintes.

Seus ideais de especialização intelectual e de profissionalização da pesquisa científica firmaram uma agenda de debates que se consolidaram em instituições - a Universidade do Rio de Janeiro em 1920, a Associação Brasileira de Educação em 1924, o Instituto Nacional de Pesos e Padrões em 1930, o Manifesto dos Pioneiros da Educação Nova em 1932, a Universidade do Distrito Federal em 1935, a Sociedade Brasileira para o Progresso da Ciência em 1948 e o Conselho Nacional de Pesquisas (CNPq) em 1951.

No universo da vulgarização científica, essa mesma geração discutiu se a difusão da ciência contribuiria para despertar vocações científicas; se funcionaria como um fator de engrandecimento do país; se seria capaz de romper com o preconceito que, então, julgavam muito assentado, do saber como um luxo e um privilégio de poucos; ou se poderia, enfim, des- 
pertar na sociedade grande confiança nos métodos científicos, de modo a desdobrarem suas pesquisas com acentuada autonomia. As instituições que ajudaram a criar, os debates que promoveram, os desafios que lançaram, seus roteiros, enfim, são pertinentes até hoje.

\section{Notas}

1 Ad Immortalitatem' (O Globo, 18/06/1959 - Arquivo Pessoal Oswaldo Cruz, Centro de Memória/ABL).

2 O mesmo argumento era defendido pelo acadêmico Salvador de Mendonça. 'Ad Immortalitatem' (O Globo, 18/06/1959 - Arquivo Pessoal Oswaldo Cruz, Centro de Memória/ABL).

3 'Oswaldo Cruz, legenda centenária' (O Estado de S. Paulo, 05/08/1972 - Arquivo Pessoal Oswaldo Cruz, Centro de Memória/ABL).

4 O tema também aparece em 'Dois depoimentos sobre Oswaldo Cruz' (Jornal do Brasil, 10/12/1940) e em Afrânio Peixoto. 'O que abala as montanhas' (O Jornal, 11/02/1927 - Arquivo Pessoal Oswaldo Cruz. Centro de Memória/ABL).

5 A rigor, a imprensa era particularmente incisiva nas críticas quando da entrada de médicos e 'cientistas' na ABL. No entanto, não se pode deixar de mencionar o escândalo provocado pela eleição de Lauro Müller para a Academia. E a sua entrada foi particularmente censurada por ter acontecido em 1912, ou seja, o ano da eleição de Oswaldo Cruz. O golpe certamente foi muito forte para os ciosos da 'literatura' como 'arte de ficção'.

6 'Discurso de Aloísio de Castro na ABL', 1929 (Arquivo Pessoal Aloísio de Castro. Centro de Memória/ABL).

7 Nos seus arquivos, há uma única notícia sobre esta acusação de plágio que estaria respondendo na França. E nela, consta que teria sido inclusive intimado a comparecer nos tribunais parisienses. A escassez de referências leva a considerar a implicância, mas a desconfiar da autenticidade dessa acusação do poeta francês Albert Samain, de quem Castro teria traduzido alguns poemas para justamente atribuir-lhes a sua autoria. Segundo a notícia, o plágio seria, é claro, um artifício para driblar a sua falta de talento literário. A solitária fonte intitula-se 'A justiça francesa agindo contra um brasileiro. O Sr. Aloísio de Castro está sendo processado em Paris' (O Carioca, 07/08/ 1933 - Arquivo Pessoal Aló́sio de Castro. Centro de Memória/ABL).

8 Benjamin Costallat. 'Um mestre de humorismo' (Arquivo Pessoal Aloísio de Castro. Centro de Memória/ABL).

9 Sobre as candidaturas de Kehl e Chagas, ver $A$ Batalha, 12/06/1934 e O Estado da Bahia, 12/06/1934 (Arquivo Pessoal Miguel Couto. Centro de Memória/ABL).

10 Afrânio Peixoto estava se referindo à Sociedade dos Amantes da Instrução fundada em 1859 sob os auspícios do Imperador Pedro II. Sobre a sociedade, ver o Relatório da Imperial Sociedade dos Amantes da Instrução. Rio de Janeiro: Tipografia Acadêmica, 1878. 
11 'Discurso do Sr. Presidente da Academia Brasileira, o Dr. Afrânio Peixoto, na última sessão de 1922' (Arquivo Pessoal Afrânio Peixoto. Centro de Memória/ABL).

1 Discurso de recepção do Sr. Miguel Ozório de Almeida na Academia Brasileira de Letras, sucessor de Medeiros e Albuquerque, feito por Roquette-Pinto em 23 nov. 1935 (Arquivo Pessoal Roquette-Pinto, caixa 15, Centro de Memória/ABL).

13 A troca se explicaria por terem decidido que o nome Academia Brasileira de Ciências era mais adequado e forte como vínculo institucional quando da sua apresentação em congressos científicos internacionais (Ata da sessão extraordinária de 2 de dezembro de 1921. Revista de Ciências, jan.-dez., 1921, p. 94). E no que se refere aos seus vínculos no estrangeiro, a $\mathrm{ABC}$ aderiu ao Conselho Internacional de Pesquisas Químicas, ao XI Congresso Internacional de Geografia e de Etnologia (sessão de 6 de abr. 1923), ao Conselho Internacional de Pesquisas de Bruxelas (sessão de 3 maio 1926) e à comemoração do centenário de Marcellin Berthelot no ano de 1927 (sessão de 28 set. 1928). Notícias encontradas nas atas publicadas, respectivamente, na Revista da Academia Brasileira de Ciências, n. 1, abr. 1926, p. 112 e na Revista da Academia Brasileira de Ciências, n. 2, jan. 1928, p. 5 e 15.

14 Interessante é fazer notar que nas atas das reuniões da $A B C$ referem-se uns aos outros cada vez mais como 'cientistas', enquanto a expressão 'homem de ciências' passa a designar, mais especificamente, a dedicação a assuntos médicos.

15 Segundo o autor, todo esse debate teria sido travado no interior da Escola de Altos Estudos do IHGB.

16 Sobre as atribuições das ciências sociais, ver a revista $A$ Época (1906-1920).

${ }_{17}$ Roquette-Pinto. Ciência e Cientistas do Brasil. Manuscrito encontrado no seu arquivo pessoal sob a guarda do Centro de Memória da ABL, caixa 24, [s.d.]. O tema foi também arduamente debatido na $\mathrm{ABC}$, como se vê na ata da sessão de 15 de junho de 1923. Discutiram especificamente a necessidade da criação de uma Faculdade Superior de Ciências no Brasil (Revista da Academia Brasileira de Ciências, n. 1, abr. 1926, p. 112).

18 Ata da reunião da seção do ensino técnico e superior da ABE realizada em 08/10/1926 - Arquivo Pessoal Roquette-Pinto, caixa 24, Centro de Memória/ABL.

19 Ata da reunião da seção de ensino técnico e superior de 04/08/1927, Acervo ABE.

2) Ata da reunião da seção de ensino técnico e superior de 11/08/1927, Acervo ABE.

21 Esses eram alguns dos adjetivos que ouvintes da rádio mencionavam ao se referirem à programação da emissora. Acervo Rádio Sociedade do Rio de Janeiro, Rádio MEC.

22 'As viagens na literatura infantil'. Texto datilografado encontrado no Arquivo Pessoal Roquette-Pinto, caixa 15, Centro de Memória/ABL. 



\section{Conclusĩa}

Chega mais perto e contempla as palavras. Cada uma tem mil faces secretas sob a face neutra e te pergunta sem interesse pela resposta pobre ou terrível que lhe deres: trouxeste a chave? Carlos Drummond de Andrade (1969)

Nesses tempos de 'relativismo cognitivo' em que a retórica figura como pura autonomia da linguagem, fazer referência à 'prova' significa tomar partido na historiografia. Discutir a ironia com que foram colhidos os intelectuais brasileiros do século XIX, ou os velhos bacharéis e homens de letras 'enciclopédicos', foi um procedimento metodológico que aspirou a ter a força de uma 'prova' dos argumentos desenvolvidos. Em outras palavras, ao consenso o mais profundo silêncio. À polifonia o riso ensurdecedor e o espanto, evidenciando, como um pano de fundo, os ecos da suposta incompatibilidade entre a beleza da expressão, a vasta ilustração, a profissionalização intelectual e os saberes modernos.

Dentre os denunciadores dessas 'incoerências', os aspirantes à especialização científica da virada do século XIX para o XX. Em outras palavras, os herdeiros do imperativo da internacionalização dos cânones científicos, da valorização da padronização da linguagem científica e da emergência da noção limitativa da evidência, que se contrapôs por completo à deliberação, à argumentação para a adesão dos espíritos, ao convencimento e ao fascínio exercido pelo discurso oral. Nessa ocasião, fortaleceu-se a idéia de que a linguagem não era um ornamento ou uma embalagem que vestia o pensamento, mas tão-somente o veículo da realidade, a condutora das evidências. 
Além do legado dessas inflexões epistemológicas, os defensores da especialização intelectual vivenciaram os efeitos da chamada Segunda Revolução Industrial ou Tecnológica, expandindo seu ideal de divisão internacional do trabalho, sem contar ainda os estudos em fisiologia nervosa, distinguindo 'raciocínio lógico' e 'imaginação'. Filhos das ciências naturais que se desenvolveram nos museus e associações de caráter científico criados e diversificados no século XIX, acompanharam e participaram, nos periódicos, sociedades científicas e congressos, da institucionalização das ciências biomédicas e das ciências sociais no Brasil.

Com essa geração nasceu a idéia de que nunca se tinha feito, até o limiar do século XX, ciência original no país. Esse preconceito de época enraizou-se nas suas obras, nas obras dos seus contemporâneos fundadores das universidades brasileiras na década de 1930, fincando-se ainda na historiografia sobre o tema até, ao menos, a década de 1980.

Revistos os marcos temporais e a abordagem, nos últimos vinte anos a ciência foi mesmo 'descoberta' no Brasil colonial, mas ao seu lado persistiu a aversão à retórica e aos seus múltiplos saberes, como se ela não fosse o próprio ambiente em que se desenvolveram a educação e a sociabilidade intelectuais, parte mesmo do conhecimento que então se produzia, instalada como estava no centro dos esforços dos brasileiros em tornar o seu país civilizado.

Para contribuir com a reavaliação dessa premissa na historiografia da ciência no Brasil, discuti a legitimação social da atividade científica nas três primeiras décadas do século XX. Privilegiei os debates, nos jornais e revistas do período, em torno da definição da mentalidade, mas, sobretudo, da escrita científica, considerada, então, como fixa e padronizada porque permeada por conceitos e definições unívocas; da especialização dos saberes como um sintoma do crescimento dos conhecimentos e de sua obsolescência cada vez mais rápida; e do estatuto da ciência como um saber organizado, capaz de se autodotar de instituições e de uma linguagem própria. Nesse sentido, examinei como os 'cientistas' edificaram autorepresentações em torno da especialização das suas atividades, competências, linguagem e conhecimento. Grande parte das palavras associadas à atividade intelectual teve o seu conteúdo e o seu emprego alterados naquela ocasião, por isso o estudo das mudanças na linguagem que representavam transformações no trabalho cultural.

E como vimos, não transformaram somente os nomes e os sentidos das palavras que usavam para fazer referência a si mesmos, ao seu trabalho e aos seus objetos. Todas essas variações estiveram altamente relacionadas às mudanças epistemológicas ocorridas em fins do século XIX, quando 
se impôs, definitivamente, o ideal da especialização intelectual. Na sua fórmula, pleitear a especialização e uniformizar a linguagem científica era adquirir objetividade intelectual e integrar o debate internacional.

De todo modo, essas variações precisam ser matizadas. Não houve, definitivamente, imediata ruptura no padrão intelectual do período com a emergência dessa geração de homens de ciência/cientistas, dado que, eles próprios, a despeito das suas falas de interrupção com o 'passado enciclopédico', não eram, ao fim, especializados. Atuaram, concomitantemente, como médicos, sanitaristas, cientistas naturais e sociais, educadores, engenheiros, advogados, administradores e literatos.

No entanto, ao filiar-me à historiografia intelectual que prioriza o estudo dos diferentes usos das idéias num mesmo contexto discursivo, preteri a ferrenha filiação dos autores a rígidas correntes de pensamento, para perceber os seus discursos como performativos, como 'atos de fala'. Com isso, busquei examinar o sentido histórico da exaltação da sua singularidade geracional. E ela explica-se pela descompensação entre o padrão de produção intelectual enciclopédico, de um lado, e o especializado, de outro. No padrão enciclopédico, o saber era entendido como 'exemplo', como 'autoridade' e 'modelo', não importando, digamos, a nacionalidade ou a origem das teorias. Se servissem para fazer progredir o país, atualizando-o com os padrões europeus-símbolos da civilização, eram, portanto, todas aplicáveis. No padrão especializado, ao contrário, passou-se a conferir importância a categorias e procedimentos analíticos invariáveis, mas que deveriam funcionar como uma busca de 'soluções brasileiras' para 'problemas brasileiros'. De onde a recorrente ênfase na realização de uma ciência 'nacional', 'original', em todo esse período. Por essa variação na maneira de conceber a produção intelectual, com essa geração, exatamente, fortaleceu-se uma convicção generalizada de que a 'vasta ilustração' seria uma qualidade negativa do espírito, e de que ela teria sido o perfil por excelência da produção intelectual brasileira de todos os séculos anteriores dado que fruto da herança ibérica. Espécie de cancro, paralisando, carcomindo, dispersando e adulterando a verdadeira percepção do que se lhes passava em torno. Urgia, portanto, no seu dizer, tornar os produtos do espírito 'práticos', 'modernos' e 'úteis'. Nas suas falas, a contemplação romântica fora substituída pelo objetivismo científico, e a observação da realidade teria limitado a indisciplina mental.

E nessa crítica, além da censura ao enciclopedismo humanista, incluíram também o que chamavam de o 'empiricismo' da clínica médica com suas terapêuticas baseadas nas argúcias da memória em bem relacionar conhecimentos teóricos a casos clínicos. No mais, toda expressão ou 
produção intelectual sem ajustado perfil profissional era imediatamente desqualificada pelos seus pretensos excessos de palavras e leituras. Em suma, era 'retórica'. Não mais o culto da beleza da expressão e a felicidade de dominar a maior variedade possível de assuntos, autores e ramos do conhecimento. Era uma espécie de xingamento, que traduzia o ceticismo, bastante difundido, em relação à competência dos intelectuais que pretendiam passear pelos saberes.

E ao salientarem o incremento das aptidões e vocações individuais, esses cientistas foram os atores fundamentais das reformas e novas políticas educacionais levadas a cabo na década de 1920, cuja culminância, aliás, foi o conhecido Manifesto dos Pioneiros da Educação Nova lançado em 1932. No Manifesto e em nome do novo espírito científico, a cultura geral foi definitivamente sepultada como hedonismo intelectual e erudição - não só contemplativa, mas também passiva, superficial, acrítica, verbalista, anárquica, enciclopédica, literária, autodidata, enfim, como uma superposição inútil de informações e de frases feitas.

Quanto à mudança nos modelos e padrões de produção intelectual no país, não há data precisa a fixar um fim ou um novo começo, nem 'causa' indiscutível a estabelecer, fazer encadear e explicar as mudanças. A emergência de novos cânones teóricos presumindo a fixidez e a especificidade da linguagem científica; a valorização da divisão social do trabalho nos países europeus que se industrializavam e se urbanizavam; a modernização da Capital Federal e a sensação generalizada tanto de afastamento da herança ibérica quanto da obrigatoriedade da administração do uso do tempo foram alguns dos eventos que ajudaram a fortalecer a importância da delimitação das fronteiras entre as disciplinas. Contemporaneidade dos debates, na Europa e no Brasil, e justaposição da herança cultural com os então novos paradigmas científicos são os elementos a reter nessa história. As referências cômicas citadas no início do livro demonstram tão-somente a perplexidade com o entrelaçamento de dois tempos, assim como ainda o desajustamento entre diferentes modelos analíticos e variados tipos sociais. Uns em vias de desaparecer, como os enciclopédicos, outros em vias de se estabelecer, como os especialistas.

E quanto aos aspirantes a especialistas, da sua agenda, das suas meras intenções e esforços, dos múltiplos papéis que representaram e das palavras que entoaram nasceram a Academia Brasileira de Ciências em 1916, a Universidade do Rio de Janeiro em 1920, a Rádio Sociedade do Rio de Janeiro em 1923, a Associação Brasileira de Educação em 1924, o Instituto Nacional de Pesos e Padrões em 1930, a Universidade de São Paulo 
em 1934, a Universidade do Distrito Federal em 1935, a Sociedade Brasileira para o Progresso da Ciência em 1948 e o CNPq em 1951.

Com eles desenvolveu-se, no Brasil, a premissa de que trabalhos especializados seriam mais consistentes. No seu entender, intelectuais especializados seriam mais eficazes em conjunto, permitindo um amplo trabalho em equipe nas imaginações, planos e instituições; e nos seus projetos, transformariam todo o país garantindo-lhe um novo rumo. Ao fim, uma frase do incansável Roquette-Pinto ilustra como nenhuma outra toda a sua motivação recheada das contradições que só os humanos demasiadamente humanos podem exibir. Nela, demonstra toda a riqueza das suas falas de especialização quando ainda não eram efetivamente especializados: "(...), tão certo é que os homens juntos pensam de modo muito diferente do que pensam separados" (1937: 85). 



\section{Referencicias Bibliográficas}

\section{FONTES PRIMÁRIAS}

\section{RELATÓRIOS DE CONGRESSO E GUIAS DE EXPOSIÇÃO}

BRAZIL, A. W. (Org.) Reunião do Congresso Científico Latino-Americano: 1905. Atos solenes, visitas e excursões. Rio de Janeiro: Imprensa Nacional, 1909. Tomo VIII.

FREITAS, A. de P. (Org.) Reunião do Congresso Científico Latino-Americano: 1905. Relatório Geral: trabalhos preliminares e inauguração do congresso. Rio de Janeiro: Imprensa Nacional, 1906. Tomo I.

EXPOSITION UNIVERSELLE DE 1900. Séjours à Paris pendant l'Exposition de 1900. Paris: Société Française des Voyages Duchemain, 1900.

GUIDES BALLE. L'Exposition et les Attractions de Paris et de l'Exposition. Paris: O. Balle, 1900. PARIS EXPOSITION. Guide Pratique du Visiteur de Paris et de l'Exposition. Paris: Hachette, 1900.

\section{PERIÓDICOS BRASILEIROS}

Almanaque Garnier (1903-1914)

Anais da Academia de Medicina do Rio de Janeiro (1904-1916)

Boletim da Academia Nacional de Medicina (1919)

Boletim da ABE (1927)

Brasil Acadêmico (1910) 
Braziléa (1917-1918)

Careta (1907-1908)

Ciência e Educação (1929-1930)

Ciências e Letras (1912-1918)

Ciência Médica (1929)

A Educação (1925)

A Época (1906-1920)

Elétron (1926)

Fon-Fon! (1907)

Kosmos (1908)

Rádio (1924)

Renascença (1904-1908)

Revista da Academia Brasileira de Ciências (1926-1928)

Revista Americana (1909-1919)

Revista da Semana (1900)

Revista do Brasil (1917-1927)

Revista do Centro 21 de setembro (1911)

Revista de Ciências (1920-1922)

Revista de Educação Pública (1951-1954)

Revista da Sociedade Brasileira de Ciências (1917-1919)

Revista do IHGB (1900-1924)

\section{Periódicos Franceses}

J'Apprends Tout. Revue littéraire, hebdomadaire, artistique, scientifique (1906)

Je m'Instruis et la Science pour Tous. Inventions, découvertes, applications scientifiques et pratiques (1910)

Je Sais Tout. Encyclopédie Mondiale Illustrée (1905)

La Science au XXe Siècle. Nouvelle revue illustrée des sciences et de leurs applications (1904-1907)

La Science Moderne: journal illustré (1891)

Le Phare Illustré. Revue mensuelle internationale d'actualité littéraire, scientifique et commercial (1898)

Revue Scientifique (1900-1902)

Revue du Mois (1906) 


\title{
Arquivos Pessoais (Centro de Memória da Academia Brasileira DE LETRAS)
}

\author{
Afrânio Peixoto \\ Aloíso de Castro \\ Edgard Roquette-Pinto \\ Miguel Couto \\ Miguel Ozório de Almeida \\ Oswaldo Cruz
}

\section{FONTES SECUNDÁRIAS}

ALMEIDA, M. O. de. A Mentalidade Científica no Brasil. Rio de Janeiro: Livraria Científica Brasileira, 1922 .

ALMEIDA, M. O. de. Homens e Coisas de Ciência. São Paulo: Ed. Monteiro Lobato, 1925.

ALMEIDA, M. O. de. A Vulgarização do Saber. Rio de Janeiro: Ariel Editora Ltda, 1931.

ALMEIDA, M. O. de. Ensaios, Críticas e Perfis. Rio de Janeiro: Briguiet e Cia, 1938.

BARRETO, P. (João do Rio). O Momento Literário. Rio de Janeiro/Paris: Garnier, s.d.

BARRETO, P. (João do Rio). A Alma Encantadora das Ruas. São Paulo: Companhia das Letras, 1997.

BEAUMARCHAIS, J.-P. de; COUTY, D. \& REY, A. Dictionnaire des Littératures de Langue Française. Paris: Bordas, 1994.

BENOÎT, P. Le métier littéraire. In: FEBVRE, L. (Org.) Encyclopédie Française: arts et littératures dans la société contemporaine II. Paris: Société de Gestion de l'Encyclopédie Française, Librairie Larousse, 1936. Tome XVII.

BOMFIM, M. A América Latina: males de origem. Rio de Janeiro: Topbooks, 1993.

CARVALHO, E. de. Five O'Clock. Rio de Janeiro/Paris: Garnier, 1909.

COSTA, L. E. da. O Rio de Janeiro do Meu Tempo. Rio de Janeiro: Imprensa Nacional, 1938. 3v.

COUTO, A. M. do. Dicionário da Maior Parte dos Termos Homônimos e Equívocos da Língua Portuguesa. Lisboa: Tipografia de Antonio José da Rocha, 1842. (Edição aumentada e enriquecida)

CRESSON, A. La Malaise de la Pensée Philosophique. Paris: Alcan, 1905.

DISCURSOS ACADÊMICOS (1927-1932). Rio de Janeiro: Empresa Editora ABC Limitada, 1937. v.VII.

FigueIREDO, C. de. Novo Dicionário da Língua Portuguesa. Lisboa: Livraria Editora Tavares Cardoso e Irmão, 1899. 2v. 
FLEIUSS, M. História da imprensa. In: Dicionário Histórico, Geográfico e Etnográfico do Brasil. Rio de Janeiro: Imprensa Nacional/Instituto Histórico e Geográfico Brasileiro. 1922, v.I. (Comemorativo do Primeiro Centenário da Independência)

FREIRE, L. Grande e Novíssimo Dicionário da Língua Portuguesa. 2.ed. Rio de Janeiro/São Paulo/Belo Horizonte/Recife/Porto Alegre: José Olympio, 1954. 5v.

GOMES, A. História literária. In: Dicionário Histórico, Geográfico e Etnográfico do Brasil. Rio de Janeiro: Imprensa Nacional/Instituto Histórico e Geográfico Brasileiro, 1922. v.I. (Comemorativo do Primeiro Centenário da Independência)

LASTEYRIE, R. de. \& VIDIER, A. Bibliographie Génèrale des Travaux Historiques et Archéologiques Publiés par les Sociétés Savantes de la France. Paris: Ministère de l'Instruction Publique, 1972. $7 \mathrm{v}$.

LEÃO, M. Roteiro de duas gerações. A Manhã, Rio de Janeiro, 9 ago. 1942, p. 22

LE BON, G. Psychologie des Foules. Paris: Puf, 1981. [1.ed., 1895]

PAPINI, G. Il Crepusculo dei Filosofi. Milano: Societá Editrice Lombarda, 1906.

PÉGUY, C. Oeuvres en Prose Complètes. Paris: Gallimard, 1988. v. I. [1.ed., 1907]

POINCARÉ, H. La Valeur de la Science. Paris: Flammarion, 1904.

POINCARÉ, H. La Science et l'Hipothèse. Paris: Flammarion, 1968. [1.ed., 1902]

REIS, A. A. de S. História científica. In: Dicionário Histórico, Geográfico e Etnográfico do Brasil Rio de Janeiro: Imprensa Nacional/Instituto Histórico e Geográfico Brasileiro, 1922. v.I. (Comemorativo do Primeiro Centenário da Independência)

ROQUETTE-PINTO, E. Seixos Rolados. Rio de Janeiro: Sussekind \& Mendonça, Machado \& Cia, 1927.

SANTOS, M. P. de O. Instrução pública. In: Dicionário Histórico, Geográfico e Etnográfico do Brasil Rio de Janeiro: Imprensa Nacional/Instituto Histórico e Geográfico Brasileiro, 1922. v.I. (Comemorativo do Primeiro Centenário da Independência)

VERÍSSIMO, J. Que é Literatura? E Outros Escritos. Rio de Janeiro/Paris: Garnier, 1907.

VIEIRA, F. D. Grande Dicionário Português ou Tesouro da Língua Portuguesa. Porto: Ernesto Chardron e Bartholomeu H. de Moraes, 1871. 5v.

\section{LIVROS, TESES E ARTIGOS}

ABREU, R. O Enigma de Os Sertões. Rio de Janeiro: Rocco/Funarte, 1998.

AlmeIDA, A. C. L. de. A República das Letras na Corte da América Portuguesa: a reforma dos estudos menores no Rio de Janeiro setecentista, 1995. Dissertação de Mestrado, Rio de Janeiro: UFRJ/Programa de Pós-Graduação em História Social.

ALONSO, A. Idéias em Movimento: a geração 1870 na crise do Brasil-Império. São Paulo: Paz e Terra, 2002. 
ALVES, I. M. da S. Modelo, produção e reprodução na ciência: as escolas na formação do campo científico no Brasil (séc. XIX-XX). Fórum Educacional, 114(3): 31-39, 1990.

ALVeS, J. J. de A. A Ciência: as atividades que se fizeram em seu nome (1920-1950), 1989. Tese de Doutorado, São Paulo: USP/FFLCH.

ANDRADE, A. M. R. de (Org.) A Terceira Reunião do Congresso Scientifico Latino-Americano: ciência e política. Brasília/Rio de Janeiro: CGEE/Museu de Astronomia e Ciências Afins, 2002.

ANDRADE, C. D. de. Reunião - 10 livros de poesia. Rio de Janeiro: José Olympio, 1969.

ARENDT, H. Entre o Passado e o Futuro. São Paulo: Perspectiva, 1992.

ARENDT, H. A Dignidade da Política. Rio de Janeiro: Relume-Dumará, 1993.

AZEVEDO, F. de. (Org.) As Ciências no Brasil. 2.ed. Rio de Janeiro: UFRJ, 1994. 2v.

BACZKO, B. Imaginação social. In: ROMANO, R. (Org.) Enciclopédia Einaudi: anthroposhomem. Lisboa: Imprensa Nacional Casa da Moeda, 1985. v.5.

BAHIA, J. História da Imprensa Brasileira. 4.ed. São Paulo: Ática, 1990. v.1.

BARBOSA, J. A. A Tradição do Impasse. São Paulo: Ática, 1974.

BARKER, F. The Tremulous Private Body: essays on subjection. Nova Iorque: Methuen, 1984.

BARNES, B. \& SHAPIN, S. (Eds.) Natural Order: historical studies of scientific culture. Bervely Hills/Londres: Sage Publications INC, 1979.

BARROS, R. S. M. de. A Ilustração Brasileira e a Idéia de Universidade. São Paulo: Convívio/ Edusp, 1986.

BAUMAN, Z. Legislators and Interpreters: on modernity, post-modernity and intellectuals. Nova Iorque: Cornell University Press, 1987.

BÉGUET, B. (Org.) La Science pour Tous: sur la vulgarisation scientifique en France de 1850 à 1914. Paris: Bibliothèque du Conservatoire National des Arts et Métiers, 1990.

BELAVAL, Y. Digressions sur la Rhétorique. Paris: Éditions Ramsay, 1988.

BELY, N. et al. Procédures d'Analyse Sémantique Appliquées à la Documentation Scientifique. Paris: Gauthier-Villars, 1970.

BENCHIMOL, J. L. Manguinhos do Sonho à Vida: a ciência na Belle Époque. Rio de Janeiro: Fiocruz, 1990.

BENCHIMOL, J. L. Pereira Passos: um Haussmann tropical - a renovação urbana da cidade do Rio de Janeiro no início do século XX. Rio de Janeiro: Secretaria Municipal de Cultura, Turismo e Esportes/Departamento Geral de Documentação e Informação Cultural/ Divisão de Editoração, 1992.

BENCHIMOL, J. L. Dos Micróbios aos Mosquitos: febre amarela e a revolução pasteuriana no Brasil. Rio de Janeiro: Fiocruz/UFRJ, 1999.

BENDA, J. La France Byzantine ou le Triomphe de la Littérature Pure. Paris: Gallimard, 1975. 
BENJAMIN, W. A Modernidade e os Modernos. 2.ed. Rio de Janeiro: Tempo Brasileiro, 2000.

BERGSON, H. Le Rire: essai sur la signification du comique. Paris: PUF, 1978.

BERNUCCI, L. M. A Imitação dos Sentidos: prógonos, contemporâneos e epígonos de Euclides da Cunha. São Paulo: Edusp, 1995.

BERTHELOT, J.-M. Épistémologie des Sciences Sociales. Paris: PUF, 2001.

BIARD, A.; BOUREZ, D. \& BRIAN, É. (Orgs.) Henri Berr et la Culture du XXe Siècle: histoire, science et philosophie. Paris: Albin Michel, 1997.

BLAISE, F. Études sur la Genèse du Système Scientifique Moderne. Lille: Presses Universitaires de Lille, 1991.

BOIA, L. Pour une Histoire de l'Imaginaire. Paris: Les Belles Lettres, 1999.

BOVÉ, P. Intellectuals in Power: a genealogy of critical humanism. Nova Iorque: Columbia University Press, 1986.

BRITO, N. Oswaldo Cruz: a construção de um mito da ciência brasileira. Rio de Janeiro: Fiocruz, 1995.

BROCA, B. A Vida Literária no Brasil: 1900. Rio de Janeiro: José Olympio, 1975.

BROCA, B. Naturalistas, Parnasianos e Decadistas: vida literária do realismo ao pré-modernismo. Campinas: Unicamp, 1991.

BURKE, P. A Arte da Conversação. São Paulo: Unesp, 1995.

BURKE, P. Desafios de uma história polifônica. Caderno Mais! Folha de S. Paulo, São Paulo, 15 out. 2000 .

BURKE, P. Uma História Social do Conhecimento: de Gutemberg a Diderot. Rio de Janeiro: Jorge Zahar, 2003.

BURKE, P. \& PORTER, R. Linguagem, Indivíduo e Sociedade. São Paulo: Unesp, 1993.

BURKE, P. \& PORTER, R. Línguas e Jargões: contribuições para uma história social da linguagem. São Paulo: Unesp, 1997a.

BURKE, P. \& PORTER, R. (Orgs.) História Social da Linguagem. São Paulo: Unesp, 1997b.

CABRAL, D. Da Barbárie à Civilização: a cidade do Rio de Janeiro no discurso da Academia Imperial de Medicina (1870-1890), 1995. Dissertação de Mestrado, Rio de Janeiro: UFRJ/Programa de Pós-Graduação em História Social.

CAILlARD, M. Les Revues d'Avant-garde. Paris: J.-M. Place, 1990.

CANDIDO, A. Literatura e Sociedade. 2.ed. São Paulo: Companhia Editora Nacional, 1967.

CANDIDO, A. O Método Crítico de Sílvio Romero. 3.ed. São Paulo: Edusp, 1988.

CANDIDO, A. Formação da Literatura Brasileira: momentos decisivos. Belo Horizonte: Rio de Janeiro: Itatiaia, 1997. $2 \mathrm{v}$.

CANDIDO, A. O Romantismo no Brasil. São Paulo: Humanitas/FFLCH, 2002. 
CAPONI, S. El veneno y el mosquito: aspectos epistemológicos de la etiología y la profilaxis de la fiebre amarilla. História, Ciências, Saúde - Manguinhos, VII(2): 249-280, jul.out., 2000.

CAPONI, S. La generación espontánea y la preocupación higienista por la diseminación de los gérmenes. História, Ciências, Saúde - Manguinhos, 9(3): 591-608, set.-dez. 2002a.

CAPONI, S. Trópicos, microbios y vectores. História, Ciências, Saúde - Manguinhos, 9 (supl.) 111-138, 2002b.

CAPONI, S. Coordenadas epistemológicas de la medicina tropical. História, Ciências, Saúde - Manguinhos, 10(1): 113-149, jan.-abr., 2003.

CARVAlHO, J. M. de. A Construção da Ordem: a elite política imperial. Brasília: Universidade de Brasília, 1981.

CARVALHO, J. M. de. A Formação das Almas: o imaginário da República no Brasil. São Paulo: Companhia das Letras, 1990.

CARVALHO, J. M. de. Historia intelectual: la retórica como clave de lectura. Prismas Revista de História Intelectual, 2: 149-168, 1998.

CARVAlHO, J. M. de. et al. Sobre o Pré-Modernismo. Rio de Janeiro: FCRB, 1988.

CARVALHO, M. A. R. de. A institucionalização das ciências sociais e o campo da saúde. In: CANESQUi, A. M. (Org.) Ciências Sociais e Saúde. São Paulo: Hucitec/Abrasco, 1997.

CARVAlHO, M. A. R. de. \& LIMA, N. T. O argumento histórico nas análises de saúde coletiva. In: TEIXEIRA, S. F. (Org.) Saúde Coletiva? Questionando a Onipotência do Social. Rio de Janeiro: Relume-Dumará, 1993.

CASSAGne, A. La Théorie de l'Art pour l'Art en France chez les Derniers Romantiques et les Premiers Réalistes. Paris: L. Dorbon, 1959.

CASSEN, B. (Org.) Quelles Langues pour la Science? Paris: La Découverte, 1990.

CASSIRER, E. A Filosofia do Iluminismo. Campinas: Unicamp, 1992.

CHALINE, J-P. Sociabilité et Érudition: les sociétés savantes en France. Paris: Éditions du Comité des Travaux Historiques et Scientifiques, 1995.

CHALMERS, A. La Fabrication de la Science. Paris: La Découverte, 1991.

CHARLE, C. La Crise Littéraire à l'Époque du Naturalisme: roman, théâtre, politique. Paris: Presses de l'École Normale Supérieure, 1979.

CHARLE, C. Naissance des "Intellectuels": 1880-1900. Paris: Les Éditions de Minuit, 1990.

CHARLE, C. Les Intellectuels en Europe au XIXe Siècle. Paris: Ed. du Seuil, 1996.

CHARTIER, R. História Cultural: entre práticas e representações. Lisboa: Difel, 1990.

CHARTIER, R. O homem de letras. In: VOVElle, M. (Org.) O Homem do Iluminismo. Lisboa: Editorial Presença, 1997. 
CHEVREL, Y. Le Naturalisme: étude d'un mouvement littéraire international. Paris: Puf, 1982.

CHRISTIN, O. Comment naquit la conception moderne de l'art. Le Monde des Livres. Le Monde, Paris, 19 set. 2003.

CLARKE, E. \& JACYNA, L. S. Nineteenth-Century Origins of Neuroscientific Concepts. Los Angeles: University of California Press, 1987.

COCHART, D. \& HAROCHE, C. La république et la science. Cahier d'Histoire et de Philosophie des Sciences, 27: 65-78, 1989.

COELHO, E. C. Profissões Imperiais: medicina, engenharia e advocacia no Rio de Janeiro 1822-1930. Rio de Janeiro: Record, 1999.

COHEN, Y. \& DROUIN, J.-M. (Orgs.) Cahiers d'Histoire et de Philosophie des Sciences, 27, 1989. (Número Special "Amateurisme")

COSTA, J. C. Contribuição à História das Idéias no Brasil. 2.ed. Rio de Janeiro: Civilização Brasileira, 1967.

COSTA, J. C. Pequena História da República. 3.ed. São Paulo: Brasiliense, 1989.

CoutinHo, A. (Dir.) A Literatura no Brasil. Rio de Janeiro: Sul Americana, 1969, v.3.

CROSLAND, M. Science under Control: the French Academy of Sciences - 1795-1914. Cambrigde: Cambrigde University Press, 1992.

CUNHA, L. A. A Universidade Temporã. Rio de Janeiro/Fortaleza: Civilização Brasileira/ Universidade Federal do Ceará, 1980.

DANTES, M. A. Fases da implantação da ciência no Brasil. Quipu, 2(5): 265-75, 1988.

DANTES, M. A. Os positivistas brasileiros e as ciências no final do século XIX. In: DANTES, M. A. et al. (Orgs.) A Ciência nas Relações Brasil-França. São Paulo: Edusp/ Fapesp, 1996.

DANTES, M. A. (Org.) Espaços da Ciência no Brasil: 1800-1930. Rio de Janeiro: Fiocruz, 2001a.

DANTES, M. A. As instituições imperiais na historiografia das ciências no Brasil. In: HEIZER, A. \& VIEIRA, A. A. P. (Orgs.) Ciência, Civilização e Império nos Trópicos. Rio de Janeiro: Access, 2001b.

DARNTON, R. Intelectual and cultural history. In: KAMMEN, M. (Ed.) The Past Before Us: contemporary historical writing in the United States. Ithaca: Cornell University Press, 1986.

DARNTON, R. O Beijo de Lamourette: mídia, cultura e revolução. São Paulo: Companhia das Letras, 1990.

DASCAL, M. A construção das teorias. Caderno Mais! Folha de S. Paulo, 21 maio 2000.

DÉGUY, J. (Org.) L’Intellectuel et ses Miroirs Romanesques (1920-1960). Lille: Presses Universitaires de Lille, 1993.

DESPY-MEYER, A. \& DEVRIESE, D. (Orgs.) Positivismes, Philosophie, Sociologie, Histoire, Sciences. Turnhout: Brepols, 1999. 
DHOMBRES, N. \& DHOMBRES, J. Naissance d'un Nouveau Pouvoir: sciences et savants en France: 1793-1824. Paris: Payot, 1989.

DIAS, M. O. da S. Aspectos da Ilustração no Brasil. Revista do IHGB, 278: 105-170, jan.mar., 1968.

DOMingUES, H. M. B. A Noção de Civilização na Visão dos Construtores do Império (a Revista do Instituto Histórico e Geográfico Brasileiro: 1838-1850/60), 1989. Dissertação de Mestrado, Niterói: UFF/Departamento de História.

DOMINGUES, H. M. B. Ciência: um caso de política - as relações entre as ciências naturais e agricultura no Brasil Império, 1995. Tese de Doutorado, São Paulo: USP/FFLCH.

DOYLE, P. História de Revistas e Jornais Literários. Rio de Janeiro: Fundação Casa de Rui Barbosa, 1984.

DUARTE, R. H. Em todos os lares, o conforto moral da ciência e da arte - a Revista Nacional de Educação e a divulgação científica no Brasil (1932-1934). História, Ciência, Saúde - Manguinhos, 11 (1): 33-56, 2004.

EDLER, F. C. As Reformas do Ensino Médico e a Profissionalização da Medicina na Corte do Rio de Janeiro: 1854-1884, 1992. Dissertação de Mestrado, São Paulo: USP/FFLCH.

EDLER, F. C. A Constituição da Medicina Tropical no Brasil Oitocentista: da climatologia à parasitologia médica, 1999. Tese de Doutorado, Rio de Janeiro: Uerj/IMS.

EDLER, F. C. A medicina acadêmica imperial e as ciências naturais. In: HEIZER, A. \& VIEIRA, A. A. P. (Orgs.) Ciência, Civilização e Império nos Trópicos. Rio de Janeiro: Access, 2001.

EL FAR, A. A Encenação da Imortalidade: uma análise da Academia Brasileira de Letras nos primeiros anos da República (1897-1924). Rio de Janeiro: FGV, 2000.

ELIAS, N. O Processo Civilizador 1: uma história dos costumes. Rio de Janeiro: Jorge Zahar, 1993.

ELIAS, N. O Processo Civilizador 2: formação do estado e civilização. Rio de Janeiro: Jorge Zahar, 1994.

ELIAS, N. A Sociedade de Corte. 2.ed. Lisboa: Editorial Estampa, 1995.

FEBVRE, L. Civilisation: évolution d'un mot et d'un groupe d'idées. In: FEBVRE, L. (Org.) Civilisation: le mot et l'idée. Paris: Renaissance du Livre, 1936.

FERNANDES, A. M. A Construção da Ciência no Brasil e a SBPC. 2.ed. Brasília: UNB, 2000.

FERREIRA, L. O. Os Politécnicos: ciência e reorganização social segundo o pensamento positivista da Escola Politécnica do Rio de Janeiro: 1862-1922, 1989. Dissertação de Mestrado, Rio de Janeiro: UFRJ/Departamento de Sociologia.

FERREIRA, L. O. O Nascimento de uma Instituição Científica: o periódico médico brasileiro da primeira metade do século XIX, 1996. Tese de Doutorado, São Paulo: USP/FFLCH.

FERREIRA, L. O.; FONSECA, M. R. F. da. \& EDLER, F. A Faculdade de Medicina do Rio de Janeiro no século XIX: a organização institucional e os modelos de ensino. In: DANTES, M. A. (Org.) Espaços da Ciência no Brasil: 1800-1930. Rio de Janeiro: Fiocruz, 2001. 
FERRI, M. G. \& MOTOYAMA, S. História das Ciências no Brasil. São Paulo: Edusp, 1979, 4v.

FERRONE, V. O homem de ciência. In: VOVELlE, M. (Org.) O Homem do Iluminismo. Lisboa: Editorial Presença, 1997.

FERRONE, V. \& ROSSI, P. Lo Scienziato nell'Etá Moderna. Bari: Laterza, 1994.

FIGUEIREDO, B. G. A Arte de Curar: cirurgiões, médicos, boticários e curandeiros no século XIX em Minas Gerais. Rio de Janeiro: Vício de Leitura, 2002.

FIGUEIRÔA, S. F. de. M. \& LOPES, M. M. A difusão da ciência e da tecnologia através da imprensa e dos periódicos especializados (São Paulo, 1890-1930). In: ALVES, I. \& GARCIA, E. M. (Orgs.) Anais do VI Seminário Nacional de História da Ciência e da Tecnologia. Rio de Janeiro: SBHC, 1997.

FONSECA, G. da. Biografia do Jornalismo Carioca (1808-1908). Rio de Janeiro: Quaresma, 1941.

FONSECA, M. R. F. da. As Conferências Populares da Glória: a divulgação do saber científico. História, Ciências, Saúde - Manguinhos, 2(3): 35-166, nov.1995-fev.-1996.

FONSECA, M. R. F. da. Expressões da ilustração brasileira e a saúde pública: a Sociedade Literária do Rio de Janeiro e O Patriota. In: GOLDFARB, J. L. \& FERRAZ, M. H. M. (Orgs.) Anais do V Seminário Nacional de História da Ciência e da Tecnologia. São Paulo: SBHC, 1998.

FONSECA FILHO, O. da. A Escola de Manguinhos: contribuição para o estudo do desenvolvimento da medicina experimental no Brasil. São Paulo: Revista dos Tribunais, 1974. Tomo II.

FOX, R. \& WEISZ, G. The Organisation of Sciences and Technology in France: 1808-1914. Cambrigde/Londres/Nova Iorque/Paris: Cambrigde University Press/Ed. de la Maison des Sciences de l'Homme, 1980.

FRANCE, P. Rhetoric and Truth in France: Descartes to Diderot. Oxford: Clarendon Press, 1972.

FREITAS, M. V. de. Charles Frederick Hartt: um naturalista no Império de Pedro II. Belo Horizonte: UFMG, 2002.

FREULER, L. Les tendances majeures de la philosophie autour de 1900. In: PANZA, M. \& PONT, J.-C. (Orgs.) Les Savants et l'Epistémologie vers la Fin du XIXe Siècle. Paris: A. Blanchard, 1995.

FREYRE, G. Ordem e Progresso: processo de desintegração das sociedades patriarcal e semipatriarcal no Brasil. 3.ed. Rio de Janeiro/Brasília: José Olympio/INL, 1974. 2v.

FREYRE, G. Sobrados e Mocambos: decadência do patriarcado rural e desenvolvimento do urbano. 12.ed. Rio de Janeiro: Record, 2000.

FUMAROLI, M. La République des Lettres. Diogène, 143: 131-150, jul.-sept., 1988.

FUMAROLI, M. L'Âge de l'Éloquence: rhétorique et res literaria de la Renaissance au seuil de l'époque classique. Paris: A. Michel, 1994.

FURET, F. L'Atelier de l'Histoire. Paris: Flammarion, 1982.

GALVÃO, W. N. (Org.) Euclides da Cunha. São Paulo: Ática, 1984. 
GARDIN, J.-C. Le Calcul et la Raison: essais sur la formalisation du discours savant. Paris: EHESS, 1991.

GARDIN, J.-C. et al. La Logique du Plausible: essais d'épistémologique pratique en sciences humaines. Paris: Éditions de la Maison des Sciences de l'Homme, 1987.

GATTINARA, E. C. Épistémologie, histoire et histoire des sciences. Revue de Synthèse, 4(1): 12-17, janv.-mars., 1998a.

GATTINARA, E. C. Les Inquiétudes de la Raison. Paris: Vrin, 1998b.

GAULIN, M. Le Concept d'Homme de Lettres en France à l'Époque de l'Encyclopédie. Nova Iorque: Garland, 1991.

GAY, P. O Cultivo do Ódio: a experiência burguesa da Rainha Vitória a Freud. São Paulo: Companhia das Letras, 1995.

GENTHILHOMME, Y. Les faces cachées du discours scientifique. Langue Française, (64): 29-37, 1984.

GEMELLI, G. L'encyclopédisme au XXe siècle. In: BIARD, A.; BOUREZ, D. \& BRIAN, É. (Orgs.) Henri Berr et la Culture du XXe Siècle: histoire, science et philosophie. Paris: Albin Michel, 1997.

GIERE, R. N. Explaining Science: a cognitive approach. Chicago/Londres: The University of Chicago Press, 1988.

GILLE, A. Histoire des Techniques. Paris: Gallimard, 1978.

GILLISPIE, C. C. The Edge of Objectivity: an essay in the history of scientific ideas. Princeton/ Nova Jersey: Princeton University Press, 1960.

GINGRAS, Y.; KEATING, P. \& LIMOGES, C. Du Scribe au Savant: les porteurs du savoir de l'Antiquité à la révolution industrielle. Paris: Presses Universitaires de France, 2000.

GINZBURG, C. Relações de Força: história, retórica, prova. São Paulo: Companhia das Letras, 2002.

GOFFMAN, E. A Representação do EU na Vida Cotidiana. 8.ed. Petrópolis: Vozes, 1995.

GOMES, A. de C. A dialética da tradição. Revista Brasileira de Ciências Sociais, 5(12): 1627,1990 .

GOMES, A. de C. Essa Gente do Rio...Modernismo e Nacionalismo. Rio de Janeiro: FGV, 1999.

GOMES, S. de C. Bibliotecas e Sociedade na Primeira República. São Paulo/Brasília: Pioneira/ INL, 1983.

GOULEMOT, J. Gens de Lettres: écrivains et bohèmes. Paris: Minerva, 1992.

GRENIER, J.-Y.; GRIGNON, C. \& MENGER, P.-M. Le Modèle et le Récit. Paris: Éditions de la Maison des Sciences de l'Homme, 2001.

GUILHAUMOU, J. La rhétorique du discours, objet d'histoire (XVIII-XXe siècles). Bulletin du Centre d'Analyse du Discours, 5: 149-196, 1981. 
GUILHAUMOU, J. (Org.) Le Mot: analyse du discours et sciences sociales. Aix-en-provence: Publications de l'Université de Provence, 1998.

GUILHAUMOU, J. L'Histoire des concepts: le contexte historique en débat. Annales. Histoire, Sciences Sociales, 3: 685-698, mai.-juin., 2001.

GUIMARÃES, M. L. S. Nação e civilização nos trópicos: o Instituto Histórico e Geográfico Brasileiro e o projeto de uma história nacional. Estudos Históricos, 1: 5-27, 1988.

GUSDORF, G. Dieu, la Nature, l'Homme au Siècle des Lumières. Paris: Payot, 1972a.

GUSDORF, G. Le Savoir Romantique de la Nature. Paris: Payot, 1972b.

GUSDORF, G. L'Avènement des Sciences Humaines au Siècle des Lumières. Paris: Payot, 1973.

GUSDORF, G. Introduction aux Sciences Humaines. Paris: Éditions Ophrys, 1974.

GUSDORF, G. Fondements du Savoir Romantique. Paris: Payot, 1982.

HABERMAS, J. Mudança Estrutural da Esfera Pública. Rio de Janeiro: Tempo Brasileiro, 1984

HALLEWELL, L. O Livro no Brasil (sua história). São Paulo: Edusp, 1985.

HAMPSON, N. O Iluminismo. Lisboa: Ulisséia, 1973.

HARDMAN, F. F. Engenheiros, anarquistas, literatos: sinais da modernidade no Brasil. In: CARVALHO, J. M. et al. (Orgs.) Sobre o Pré-Modernismo. Rio de Janeiro: FCRB, 1988.

HARDMAN, F. F. Antigos modernistas. In: NOVAES, A. (Org.) Tempo e História. São Paulo: Companhia das Letras, 1992.

HARTOG, F. A arte da narrativa histórica. In: BOUTIER, J. \& JULIA, D. (Orgs.) Passados Recompostos: campos e canteiros da história. Rio de Janeiro: UFRJ/FGV, 1998.

HAYEK, F. von. Scientisme et Sciences Sociales. Paris: Plon, 1953.

HEILBRON, J. Theory of knowledge and theory of science in the work of Auguste Comte: note on Comte's originality. Revue de Synthèse, 4(1): 75-89, jan.-mar., 1991.

HERSANT, Y. Disparition de la République des Lettres. Colloque Respublica Literaria - les figures de l'intellectuel européen. Bologne, janv. 1995.

HOCHMAN, G. A Era do Saneamento: as bases da política de saúde pública no Brasil. São Paulo: Hucitec/Anpocs, 1998.

HOLANDA, S. B. de. Raízes do Brasil. 15.ed. Rio de Janeiro: José Olympio, 1982.

JACOBI, D. Du discours scientifique, de sa reformulation et de quelques usages sociaux de la science. Langue Française, 64: 38-52, 1984.

JACOBI, D. La Communication Scientifique: discours, figures, modèles. Saint-Martin-d'Hères: PUG, 1999.

JUILlARD, J. Sur la causalité dans l'histoire des idées. Mil Neuf Cent - Revue d'Histoire Intellectuelle, 19: 5-18, 2001.

KARL, F. O Moderno e o Modernismo: a soberania do artista - 1885-1925. Rio de Janeiro: Imago, 1988. 
KEMPF, R. Dandies, Baudelaire et Cie. Paris: Seuil, 1977.

KNIGHT, D. The Age of Science: the scientific world-view in the nineteenth century. Nova Iorque: B. Blackwell, 1986.

KOSELLECK, R. Le Futur Passé: contribution à la sémantique des temps historiques. Paris: EHESS, 1990.

KOSELLECK, R. Uma história dos conceitos: problemas teóricos e práticos. Estudos Históricos, 5(10): 134-146, 1992.

KOSELLECK, R. Crítica e Crise. Rio de Janeiro: Eduerj/Contraponto, 1999a.

KOSELLECK, R. L'Expérience de l'Histoire. Paris: Gallimard, 1999b.

KOYRÉ, A. Estudos de História do Pensamento Científico. 2.ed. Rio de Janeiro: Forense Universitária, 1991.

KURY, L. B. O Império dos Miasmas: a Academia Imperial de Medicina (1830-1850), 1990a. Dissertação de Mestrado, Niterói: UFF/Departamento de História.

KURY, L. B. Natureza brasileira, paraíso ou inferno? Estudos de História e Saúde, 1(1): 2$25,1990 \mathrm{~b}$.

KURY, L. B. Ciência e nação: romantismo e história natural na obra de E. J. da Silva Maia. História, Ciências, Saúde - Manguinhos, 5(2): 267-291, 1998.

KURY, L. B. A comissão científica de exploração: a ciência imperial e a musa cabocla. In: HEIZER, A. \& VIEIRA, A. A. P. (Orgs.) Ciência, Civilização e Império nos Trópicos. Rio de Janeiro: Access, 2001.

LA CAPRA, D. Rethinking Intellectual History: texts, contexts, language. Ithaca: Cornell University Press, 1983.

LANDES, D. Revolution in Time: clocks and the making of modern world. Cambridge: The Belknap Press, 1983.

LATOUR, B. Les Microbes, Guerre et Paix, Suivi de Irréductions. Paris: A.-M. Métailié, 1984.

LATOUR, B. La Vie de Laboratoire. Paris: La Découverte, 1988.

LATOUR, B. Ciência em Ação: como seguir cientistas e engenheiros sociedade afora. São Paulo: Unesp, 2000.

LE GOFF, J. Les Intellectuels au Moyen Âge. Paris: Le Seuil, 1957.

LEITE, D. M. O Caráter Nacional Brasileiro. São Paulo: Pioneira, 1976.

LÉONARD, J. La pensée médicale au XIXe siècle. Revue de Synthèse, 3(109): 29-52, janv.mars., 1983.

LEPENIES, W. Sur la guerre des sciences et des belles-lettres à partir du 18e siècle. MSH Informations - Bulletin de la Fondation Maison des Sciences de l'Homme 54: 8-17, 1987.

LEPENIES, W. La Fin de l'Utopie et le Retour de la Mélancolie: regards sur les intellectuels d'un vieux continent. Paris: Collège de France, 1992. 
LEPENIES, W. As Três Culturas. São Paulo: Edusp, 1996.

LEROY, G. \& BERTRAND-SABIANI, J. La Vie Littéraire à la Belle Époque. Paris: PUF, 1998. LÉVY-LEBLOND, J.-M. La Pierre de Touche: la science à l'épreuve. Paris: Gallimard, 1996.

LICOPPE, C. La Formation de la Pratique Scientifique: le discours de l'expérience en France et en Angleterre (1630-1820). Paris: La Découverte, 1996.

LIMA, L. C. Dispersa Demanda. Rio de Janeiro: Francisco Alves, 1981.

LIMA, L. C. Sociedade e Discurso Ficcional. Rio de Janeiro: Guanabara, 1986.

LIMA, L. C. Terra Ignota: a construção de Os Sertões. Rio de Janeiro: Civilização Brasileira, 1997.

LIMA, N. T. Um Sertão Chamado Brasil. Rio de Janeiro: Revan/Iuperj/Ucam, 1999.

LIMA, N. T. \& HOCHMAN, G. Condenado pela raça, absolvido pela medicina: o Brasil descoberto pelo Movimento Sanitarista da Primeira República. In: MAIO, M. C. \& SANTOS, R. V. (Orgs.) Raça, Ciência e Sociedade. Rio de Janeiro: Fiocruz/CCBB, 1996.

LIMA, N. T. \& SÁ, D. M. de. Um mestre da ciência para todos. Revista Nossa História, 17: 72-75, mar., 2005.

LIPOVETSKY, G. L'Empire de l'Ephémère. Paris: Gallimard, 1987.

LOPES, M. M. Mais vale um jegue que me carregue, que um camelo que me derrube...lá no Ceará. História, Ciências, Saúde - Manguinhos, 3(1): 50-64, mar.-jun., 1996.

LOPES, M. M. O Brasil Descobre a Pesquisa Científica: os museus e as ciências naturais no século XIX. São Paulo: Hucitec, 1997.

LÖWY, I. On hybridizations, networks and new disciplines: the Pasteur Institute and the development of microbiology in France. Studies in History of Philosophie and Sciencies, 25(5): 655-688, 1994.

LÖWY, M. \& SAYRE, R. Révolte et Mélancolie: le romantisme à contre-courant de la modernité Paris: Éditions Payot, 1992.

MACHADO NETO, A. L. Estrutura Social da República das Letras: sociologia da vida intelectual brasileira - 1870-1930. São Paulo: Grijalbo/Edusp, 1973.

MANDROU, R. Histoire de la Pensée Européenne: des humanistes aux hommes des sciences. Paris: Le Seuil, 1973.

MARTIN-FUGIER, A. Les Romantiques. Paris: Le Grand Livre du Mois, 1998.

MARTINS, L. A gênese de uma intelligentsia: intelectuais e política no Brasil - 1920-1940. Revista Brasileira de Ciências Sociais, 2(4): 65-87, jul. 1987.

MARTINS, W. Interpretações: ensaios de crítica. Rio de Janeiro: José Olympio, 1946.

MATAGNE, P. Les mutations de la curiosité et la professionnalisation de la science. Bulletin de la Société Botanique du Centre-Ouest, 23: 3-12, 1992.

MATALON, B. La Construction de la Science: de l'épistémologie à la sociologie de la connaissance scientifique. Lausanne/Paris: Delachaux et Niestlé, 1996. 
MAYER, A. J. A Força da Tradição: a persistência do Antigo Regime (1848-1914). 2.ed. São Paulo: Companhia das Letras, 1987.

MICELI, S. Poder, Sexo e Letras na República Velha: estudo clínico dos anatolianos. São Paulo: Perspectiva, 1977.

MICELI, S. Intelectuais e Classe Dirigente no Brasil (1920-1945). São Paulo: Difel, 1979.

MICELI, S. (Org.) História das Ciências Sociais no Brasil: São Paulo: Vértice/Idesp, 1989. v.1.

MICELI, S. (Org.) História das Ciências Sociais no Brasil: São Paulo: Sumaré/Fapesp, 1995. v.2.

MICELI, S. Intelectuais brasileiros. In: MICELI, S. (Org.) O Que Ler na Ciência Social Brasileira (1970-1995)? São Paulo/Brasília: Sumaré/Anpocs/Capes, 1999.

MiGUEL-PEREIRA, L. História da Literatura Brasileira: prosa de ficção (de 1870 a 1920). Belo Horizonte/São Paulo: Itatiaia/Edusp, 1988.

MOREIRA, I. C. \& MASSARINI, L. A divulgação científica no Rio de Janeiro: algumas reflexões sobre a década de 1920. História, Ciências, Saúde - Manguinhos, 7(3): 627651, nov. 2000-fev. 2001.

MOREIRA, I. C. \& MASSARINI, L. A divulgação científica no Rio de Janeiro: um passeio histórico e o contexto atual. Revista Rio de Janeiro, 11: 39-58, set.-dez., 2003.

MORSE, R. O Espelho de Próspero: cultura e idéias nas Américas. 2.ed. São Paulo: Companhia das Letras, 1988.

MORTON, P. The Vital Science: biology and the literary imagination - 1860-1900. Londres: Allen and Unwin, 1984.

MOTA, M. A. R. Sílvio Romero: uma "imagem nervosa" do Brasil, 1992. Dissertação de Mestrado, Rio de Janeiro: UFRJ/PPGHIS.

MUNFORD, L. Tecnica y Civilisación. Madri: Alianza, 1987.

MUNTEAL FILHO, O. Ciência, natureza e sociabilidade intelectual em Portugal no século XVIII: a Academia Real das Ciências de Lisboa e os caminhos da ilustração ibérica. In: GOLDFARB, J. L. \& FERRAZ, M. H. M. (Orgs.) Anais do V Seminário Nacional de História da Ciência e da Tecnologia. São Paulo: SBHC, 1998.

NAGLE, J. A educação na Primeira República. In: FAUSTO, B. (Dir.) História Geral da Civilização Brasileira: o Brasil Republicano - sociedade e instituições (1889-1930). 5.ed. Rio de Janeiro: Bertrand Brasil, 1997. v.2.

NEEDELL, J. Belle Époque Tropical: sociedade e cultura de elite no Rio de Janeiro na virada do século. São Paulo: Companhia das Letras, 1993.

ORTIZ, R. Mundialização e Cultura. São Paulo: Brasiliense, 2003.

ORY, P. Les Expositions Universelles de Paris. Paris: Ramsay, 1982.

ORY, P. (Dir.) Dernières Questions aux Intellectuels. Paris: Olivier Orban, 1990.

ORY, P. \& SIRINELLI, J. F. Les Intellectuels en France (de l'Affaire Dreyfus à nos jours). Paris: Armand Colin, 1992. 
PANZA, M. \& PONT, J.-C. Les Savants et l'Epistémologie vers la Fin du XIXe Siècle. Paris: A. Blanchard, 1995.

PAUL, H. W. La science. In: SIRINELLI, J. F. (Org.) Sensibilités. Paris: Gallimard, 1992. v.3. PÉCAUT, D. Os Intelectuais e a Política no Brasil: entre o povo e a nação. São Paulo: Ática, 1990. PERELMAN, C. Rhétorique et Philosophie. Paris: Presses Universitaires de France, 1952.

PERELMAN, C. L'Empire Rhétorique. Paris: Vrin, 1977.

PERELMAN, C. Argumentação. In: ROMANO, R. (Org.) Enciclopédia Einaudi. Lisboa: Imprensa Nacional Casa da Moeda, 1987. v.11.

PESSANHA, J. A. A teoria da argumentação ou nova retórica. In: CARVALHO, M. C. M. de. (Org.) Paradigmas Filosóficos da Atualidade. Campinas: Papirus, 1989.

PESSANHA, J. A. O sono e a vigília. In: NOVAES, A. (Org.) Tempo e História. São Paulo: Companhia das Letras, 1992.

PESTRE, D. Les revues de vulgarisation scientifique en France, 1918-1940: un panorama. Cahiers d'Histoire et de Philosophie des Sciences, 24, 1987.

PETIT, A. Genèse de la classification des sciences d'Auguste Comte. Revue de Synthèse, 4(1-2): 71-102, janv.-juin. 1994.

PEYTARD, J. Problématique de l'altération des discours: réformulation et transcodage. Langue Française, 64: 17-28, 1984.

PICCHIO, L. S. História da Literatura Brasileira. Rio de Janeiro: Nova Aguilar, 1997.

PICON, A. Les rapports entre sciences et techniques dans l'organisation du savoir. Revue de Synthèse, 4(1-2): 103-120, janv.-juin. 1994.

PLUET-DESPATIN, J. Une contribution à l'histoire des intellectuels: les revues. Cahiers de l'Institut du Temps Present, 20, mars, 1992.

POCOCK, J. The concept of a language and the métier d'historien: some considerations on practice. In: PAGDEN, A. (Ed.) The Languages of Political Theory in Early-Modern Europe. Cambridge: Cambridge University Press, 1990.

POMIAN, K. Collectionneurs, Amateurs et Curieux. Paris: Gallimard, 1987.

POMIAN, K. Temps, espace, objets. In: REVEL, J. \& SCHMITT, J.-C. (Orgs.) L'Ogre Historien. Autour de Jacques Le Goff. Paris: Gallimard, 1998.

POMIAN, K. Sur l'Histoire. Paris: Gallimard, 1999.

PROCHASSON, C. Les congrès, lieux de l'échange intellectuel (1850-1914). Mil Neuf Cent - Revue d'Histoire Intellectuele, 7: 5-8, 1989.

PROCHASSON, C. Les Années Électriques: 1880-1910. Paris: La Découverte, 1991.

PROCHASSON, C. Héritages et trahisons: la réception des oeuvres. Mil Neuf Cent - Revue d'Histoire Intellectuelle, 12: 5-13, 1994.

PROCHASSON, C. L'affaire dans tous ses états. In: RIOUX, J. P. \& SIRINELLI, J.-F. (Orgs.) Pour une Histoire Culturelle. Paris: Seuil, 1997. 
PROCHASSON, C. Paris 1900. Paris: Calmann-Lévy, 1999.

PROCHASSON, C. \& RASMUSSEN, A. Au Nom de la Patrie: les intellectuels et la Première Guerre Mondiale (1910-1919). Paris: La Découverte, 1996.

QUEIROZ, M. I. P. de. Brésil, XIXe Siècle: les précurseurs des sciences sociales - culture, science et développement. Paris: Privat, 1979.

RACINE, N. \& TREBITSCH, M. (Orgs.) Sociabilités intellectuelles: lieux, milieux, réseaux. Cahiers de l'Institut d'Histoire du Temps Présent, 20, mars 1992.

RASMUSSEN, A. Jalons pour une histoire des congrès scientifiques internationaux au XIXe siècle: régulation scientifique et propagande intellectuelle. Les Relations Internationales (Les Congrès Scientifiques Internationaux), 62, 1990.

RASMUSSEN, A. L'Internationale Scientifique - 1890-1914, 1995. Tese de Doutorado, Paris: EHESS.

RASMUSSEN, A. Critique du progrès, 'crise de la science': débats et représentations du tournant du siècle. Mil Neuf Cent - Revue d'Histoire Intellectuelle, 14: 89-113, 1996.

RÉGALDO, M. Lumières, élite, démocratie: la difficile position des idéologies. Révue DixHuitième Siècle, 6: 193-208, 1974.

RENAN, E. L'Avenir de la Science. Paris: Calmann-Lévy, 1949.

RIOUX, J.-P. Frissons: fin-de-siècle - 1889-1900. Paris: Le Monde Éditions, 1990.

RIOUX, J.-P. \& SIRINELLI, J-F. Pour une Histoire Culturelle. Paris: Éditions du Seuil, 1997.

ROCHE, D. Les Républicains des Lettres. Paris: Fayard, 1988.

ROGER, J. Pour une Histoire des Sciences à Part Entière. Paris: Albin Michel, 1995.

ROGER, J. \& LOUIS, P. (Dirs.) Transfert de Vocabulaire dans les Sciences. Paris: CNRS, 1988.

ROllemberG, M. A Esfinge e seus Segredos: máximas e citações de Oscar Wilde. Rio de Janeiro: São Paulo: Record, 2000.

ROSSI, P. La Naissance de la Science Moderne en Europe. Paris: Seuil, 1999.

ROUSSEAU, G. S. Para uma semiótica do nervo: a história social da linguagem em novo tom. In: BURKE, P. \& PORTER, R. (Orgs.) Linguagem, Indivíduo e Sociedade. São Paulo: Unesp, 1993.

SALIBA, E. T. A dimensão cômica da vida privada na República. In: SEVCENKO, N. (Org.) História da Vida Privada no Brasil. República: da Belle Époque à era do rádio. São Paulo: Companhia das Letras, 1998. v.3.

SALIBA, E. T. Raízes do Riso: a representação humorística na história brasileira: da Belle Époque aos primeiros tempos do rádio. São Paulo: Companhia das Letras, 2002.

SALOMON-BAYET, C. Pasteur et la Révolution Pastorienne. Paris: Payot, 1986.

SAMPAIO, G. dos R. Nas Trincheiras da Cura: as diferentes medicinas no Rio de Janeiro imperial. Campinas: Unicamp, 2001. 
SANTIAGO, S. Nas Malhas da Letra. São Paulo: Companhia das Letras, 1989.

SANTOS, A. C. M. dos. (Org.) O Rio de Janeiro de Lima Barreto. Rio de Janeiro: Rioarte, 1983. $2 \mathrm{v}$.

SANTOS, A. C. M. dos. A invenção do Brasil: um problema nacional? Revista de História, 118: 3-12, jan.-jun., 1985.

SANTOS, A. C. M. dos. No Rascunho da Nação: Inconfidência no Rio de Janeiro. Rio de Janeiro: Secretaria Municipal de Cultura, Turismo e Esportes/Departamento Geral de Documentação e Informação Cultural/Divisão de Editoração, 1992.

SANTOS, A. C. M. dos. A cidade do Rio de Janeiro: de laboratório da civilização à cidade símbolo da nacionalidade. In: A Visão do Outro: seminário Brasil-Argentina. Brasília: Funag, 2000.

SANTOS, W. G. dos. A imaginação político-social brasileira. Dados, 2-3: 182-193,1967.

SANTOS, W. G. dos. Raízes da imaginação política brasileira. Dados, 7: 137-161, 1970.

SANTOS, W. G. dos. Ordem Burguesa e Liberalismo Político. São Paulo: Duas Cidades, 1978.

SENNETT, R. O Declínio do Homem Público: as tiranias da intimidade. 6.ed. São Paulo: Companhia das Letras, 1999.

SHAPIN, S. \& SHAFFER, S. Leviathan et la Pompe à l'Air. Paris: La Découverte, 1993.

SCHLANGER, J. E. Les Métaphores de l'Organisme. Paris: Vrin, 1971.

SCHVARZMAN, S. Humberto Mauro e as Imagens do Brasil. São Paulo: Unesp, 2004.

SCHWARCZ, L. K. M. O Espetáculo das Raças: cientistas, instituições e questão racial no Brasil (1870-1930). São Paulo: Companhia das Letras, 1993.

SCHWARZ, R. Ao Vencedor as Batatas. São Paulo: Duas Cidades, 1977.

SCHWARTZMAN, S. Formação da Comunidade Científica no Brasil. Rio de Janeiro/São Paulo: Companhia Editora Nacional/Finep, 1979.

SENNA, H. República das Letras. 3.ed. Rio de Janeiro: Civilização Brasileira, 1996.

SEVCENKO, N. Literatura como Missão: tensões sociais e criação cultural na Primeira República. 4.ed. São Paulo: Brasiliense, 1995.

SHEETS-PYENSON, S. Popular science periodicals in Paris and London: the emergence of a low scientific culture, 1820-1875. Annals of Science, 42(6): 549-572, 1985.

SIGRIST, R. L'expérimentation comme rhétorique de la preuve. Revue d'Histoire des Sciences, 4: 419-449, oct.-déc., 2001.

SIMMEL, G. A metrópole e a vida mental. In: VELHO, O. (Org.) O Fenômeno Urbano. Rio de Janeiro: Zahar, 1975.

SIRINELLI, J-F. Le hasard ou la nécessité? Une histoire en chantier: l'histoire des intellectuels. Vingtième Siècle - Revue d'Histoire, 9: 97-108, janv.-mars. 1986.

SIRINELLI, J-F. Effets d'âge et phénomènes de génération. Les Cahiers de l'IHTP - Générations Intellectuelles, 6: 5-12, nov. 1987. 
SIRINELLI, J-F. (Org.) Sensibilités. Paris: Gallimard, 1992. v.3.

SIRINELLI, J-F. (Dir.) École Normale: le livre du bicentenaire. Paris: Puf, 1994.

SMITH, J. H. The Spirit and its Letter: traces of rethoric in Hegel's philosophy of 'Bildung'. Ithaca: Cornell University Press, 1988.

SNOW, C. P. Les Deux Cultures. Paris: Jean-Jacques Pauvert, 1968.

SODRÉ, N. W. História da Imprensa no Brasil. 3.ed. Martins Fontes, 1983.

STAROBINSKI, J. Le Remède dans le Mal: critique et légitimation de l'artifice à l'Âge des Lumières. Paris: Gallimard, 1989.

STEPAN, N. Begginings of Brazilian Science: Oswaldo Cruz, Medical Research and Policy, 18901920. Nova Iorque: Neale Watson Academy Publications, 1976.

STOEKL, A. Agonies of the Intellectual: commitment, subjectivity and the performative in the twentieth-century french tradition. Lincoln/Londres: University of Nebraska Press, 1992.

SÜSSEKIND, F. Cinematógrafo das Letras: literatura, técnica e modernização no Brasil. São Paulo: Companhia das Letras, 1987.

SÜSSEKIND, F. O Brasil não é Longe Daqui: o narrador, a viagem. São Paulo: Companhia das Letras, 1990.

THOMPSON, E. P. Tradición, Revuelta y Consciencia de Classe. Barcelona: Crítica, 1984.

TILLY, C. An Urban World. Boston: Brown and Co., 1974.

TRAUTMANN, J. (Ed.) Healing Arts in Dialogue: medicine and literature. Carbondale/Illinois: Southern Illinois University Press, 1981.

TREBITSCH, M. \& GRANJON, M.-C. (Dirs.) Pour une Histoire Comparée des Intellectuels. Paris: Éditions Complexe, 1998.

VELLOSO, M. P. A literatura como espelho da nação. Estudos Históricos, 1(2): 239-263, 1988.

VELLOSO, M. P. Modernismo no Rio de Janeiro. Rio de Janeiro: FGV, 1996.

VENÂNCIO FILHO, A. Das Arcadas ao Bacharelismo (150 anos de ensino jurídico no Brasil). São Paulo: Perspectiva, 1982.

VENTURA, R. Estilo Tropical: história cultural e polêmicas literárias no Brasil - 1870-1914. São Paulo: Companhia das Letras, 1991.

VIANNA, L. W. A Revolução Passiva: iberismo e americanismo no Brasil. Rio de Janeiro: Revan, 1997.

VILHENA, L. R. Projeto e Missão: o movimento folclórico brasileiro (1947-1964). Rio de Janeiro: Funarte: FGV, 1997.

VOVELLE, M. (Org.) O Homem do Iluminismo. Lisboa: Editorial Presença, 1997.

WALLENBORN, G. Les enjeux de la vulgarisation des pratiques scientifiques. In: CASSEN, B. (Dir.) Quelles Langues pour la Science? Paris: La Découverte, 1990. 
WEBER, E. Fin-de-Siècle: la France à la fin du XIXe siècle. Paris: Fayard, 1986.

WEber, M. Ciência e Política: duas vocações. São Paulo: Martin Claret, 2002.

WILLIAMS, P. The Laboratory Revolution in Medicine. Cambridge: Cambridge University Press, 1992.

WILLIAMS, R. Keywords: a vocabulary of culture and society. Londres: Fontana, 1976.

WINOCK, M. O Século dos Intelectuais. Rio de Janeiro: Bertrand, 2000.

ZALUAR, A. E. O Doutor Benignus. Rio de Janeiro: UFRJ, 1994. [1.ed., 1875] 


\section{Índice Onomástico}

ABREU, João Capistrano de - 73

ABREU, Regina - 128

AGASSIZ, Louis - 126

ALENCAR, José de - 63

ALENCAR, Mário de - 154, 156

ALENCAR, Otto de - 113

ALIGHIERI, Dante - 39

ALMEIDA, Álvaro Ozório de - 18, 119, 138, $164,172,176$

ALMEIDA, Anita Correia Lima de - 60

ALMEIDA, Miguel Ozório de - 18, 22, 107,

$119,120,121,124,125,131,132,133$,

$134,136,140,141,160,164,166,167$,

$173,176,181$

ALMEIDA, Renato - 150

ALONSO, Ângela - 32

ALVES, Isidoro Maria da S. - 78

ALVES, José Jerônimo de Alencar - 15

AMARAL, Amadeu - 70, 142

AMARAL, Ignácio Azevedo do - 176

ANDRADE, Ana Maria Ribeiro de - 140

ANDRADE, Carlos Drummond de - 183

ARAGÃO, Henrique - 164

ARANHA, Graça - 67

ARAÚJO, Jorge - 128, 129, 130

ARISTÓTELES - 51
ARENDT, Hannah - 51, 99

AZEVEDO, Fernando de - 15, 28, 29, 75, $78,86,178$

BACKHEUSER, Everardo - 176

BACON, Francis - 39

BACZKO, Bronislaw - 32

BAHIA, Juarez - 44

BALZAC, Honoré de - 34, 47, 86

BANDEIRA, João Carneiro de Sousa - 48

BARBOSA, João Alexandre - 34, 35, 70, 72

BARBOSA, Rui - 22, 65, 70, 73, 84, 125,

$133,143,144,154$

BARKER, Francis - 102

BARRETO, Paulo (João do Rio) - 38, 39, 61, $68,69,70,71$

BARRETO, Plínio - 80, 82

BARROS, João de - 65

BARROS, Roque Spencer Maciel de - 29, 108, 140,175

BARROSO, Sebastião - 176

BAUDELAIRE, Charles - 71, 103

BAUMAN, Zigmunt - 26

BEAUMARCHAIS, Jean-pierre de - 71, 91

BÉGUET, Bruno - 40, 91, 92, 98, 104, 174

BELAVAL, Yvon - 52, 55

BELLO, José Maria - 46, 77, 133 
BELMONTE, Villar - 132

BENCHIMOL, jaime larry - 15, 17, 42, 110, 111,112

BENDA, Julien - 71

BENJAMIN, Walter - 82

BENOÎT, Pierre - 86

BERGSON, Henri - 46, 59

BERNARD, Claude - 91, 147

BERNUCCI, Leopoldo M. - 128

BERR, Henri - 93

BERTHELOT, Marcellin - 91, 92, 94, 104, 181

BEVILACQUA, Clóvis - 73

BIARD, Agnes - 90, 93

BILAC, Olavo - 47, 50, 59, 70, 73

BITTENCOURT, Liberato - 137

BOIA, Lucien - 91

BOMÍLCAR, Álvaro - 73

BOMFIM, Manuel - 28, 73, 74, 75

BOUGLÉ, Celestin - 104

BOUREZ, Dominique - 90, 93

BRAZIL, Américo W. - 139

BRAZIL, Vital - 111

BRIAN, Éric - 90, 93

BRITO, Nara - 111

BRITTO, Mário - 172

BROCA, Brito - 23, 42, 44, 58, 59, 65, 70, 72

BRUSCHINI, Américo - 79, 124

BUFFON, Georges Louis Leclerc de - 103, 128

BURCKARDT, Jacob - 98, 104

BURKE, Peter - 20, 26, 52, 53

BYRON, Lorde (George Gordon) - 47

CABRAL, Dilma - 33

CAMÕES, Luís de - 39, 152

CANDIDO, Antonio - 35, 36, 37, 38, 43, 57, $58,67,72,82,83$

CAPONI, Sandra - 139

CARDOSO, Jaime - 151
CARDOSO, Licínio - 164

CARVALHO, Elísio de - 58, 62, 64, 65, 66

CARVALHO, José Murilo de - 23, 29, 33, 52, $58,60,108$

CARVALHO, Maria Alice Rezende de - 140

CASSAGNE, A. - 71

CASSEN, Bernard - 60, 127

CASSIRER, Ernst -36

CASTELO, Augusto Viana do - 172

CASTRO, Aloíso de - 19, 134, 140, 141, 147, $148,149,150,151,152,153,180$

CASTRO, Olegário Herculano D’Aquino e 113,161

CASTRO E SILVA, Demócrito de - 151

CÍCERO - 51, 84

CHAGAS, Carlos - 18, 110, 155, 164, 180

CHARLE, Christophe - 25, 26, 31, 54, 58, $72,83,85,102$

CHARTIER, Roger - 25, 31, 52

CHATEAUBRIAND, Assis - 142, 150

CHEVREL, Yves - 72

CHILDE, Alberto - 176, 178

CHRISTIN, Olivier - 71

CLARKE, E. - 102

COCHART, Dominique - 93, 105

COELHO, Edmundo Campos - 23, 41, 58, $81,82,83,109$

COELHO NETO, Henrique Maximiano de $22,47,59,63,68,69,70,71,73,129$

COHEN, Yves - 95

COMTE, Augusto - 47, 108, 175

CONDILLAC, Etienne Bonnot de - 59

CORREIA, Raimundo - 68, 145

COSTA, Manuel Amoroso - 125, 164, 172

COSTA, João Cruz - 67, 70, 107, 108, 144

COSTA, Luiz Edmundo da - 48, 59

COSTALLAT, Benjamim - 71, 152, 153, 180

COUTINHO, Afrânio - 67

COUTINHO, A. Moraes - 130, 142 
COUTO, Antonio Maria do - 20, 137

COUTO, Miguel - 113, 132, 134, 141, 150, $151,152,154,155,180$

COUTY, Daniel - 71, 91

CRESSON, A. - 91

CRULS, Louis - 113

CRULS, Gastão - 50

CRUZ, Oswaldo - 18, 22, 65, 111, 116, 120 , $133,134,135,140,141,142,143,144$, $145,146,147,148,164,180$

CUNHA, Euclides da - 22, 67, 70, 116, 128, $129,130,133,158$

CUNHA, Luís Antônio - 15

DANTES, Maria Amélia - 20, 108, 124, 125

DARNTON, Robert - 24, 26

DARWIN, Charles - 91

DAUDET, Alphonse - 34

DEGUY, Jacques - 25

DE MONZIE, Anatole - 105

DEL PICCHIA, Menotti - 151, 152

DERBY, Orville - 113

DESPY-MEYER, Andrée - 124

DEVRIESE, Didier - 124

DHOMBRES, Nicole \& Jean - 94

DIAS, Antonio Gonçalves - 126

DIAS, Maria Odila Leite da Silva - 57

DOLORES, carmem - 59

DOMINGUES, Heloísa M. Bertol - 15, 34

DOYLE, Plínio - 44

DREYFUS, Alfred - 31

DREYFUS, André - 172

DROUIN, Jean-Marc - 95

DUARTE, Regina Horta - 178

DUMAS FILHO, Alexandre - 146

DUMONT, Alberto Santos - 89, 90, 103, 104

DUQUE, Gonzaga - 71

DURKHEIM, Emile - 31, 98

EDLER, Flavio Coelho - 15, 58, 109, 110, 139

EINSTEIN, Albert - 165, 176
EL FAR, Alessandra - 61, 62, 70

ELIAS, Norbert - 37, 53, 58

ENGELS, Friedrich - 98

ÉSQUILO - 39

FARIAS BRITO, Raimundo - 70, 73

FEBVRE, Lucien - 31, 58, 71

FERNANDES, Ana Maria - 15

FERREIRA, Luiz Otávio - 15, 17, 41, 58, 108, 109, 110, 141

FERREIRA, Procópio - 153

FERRI, Mario Guimarães - 15

FERRONE, Vincenzo - 92, 105

FIALHO, Abreu - 113, 135

FIALHO, Branca - 172

FIGUEIRA, Fernandes - 113, 123

FIGUEIREDO, Betânia Gonçalves - 110

FIGUEIREDO, Cândido de - 20, 137

FIGUEIREDO, Jackson de - 158

FIGUEIREDO FILHO, Afonso Celso de Assis $-73,85,155,169$

FIGUEIRÔA, Sílvia F. de M. - 17

FLAUBERT, Gustave - 34, 71

FLEIUSS, Max - 58, 163, 168, 169, 170

FONSECA, Gondim da - 44

FONSECA, Maria Rachel Fróes da - 39, 58, 110

FONSECA FILHO, Olympio da - 111

FOOT HARDMAN, Francisco - 87

FRANCE, Anatole - 31, 71

FRANCE, Peter - 52

FRANCO, A. Cardoso - 80

FREIRE, Laudelino - 20, 87, 113

FREITAS, Antonio de Paula - 112, 113, 114, 140,141

FREITAS, Marcus Vinícius de - 126

FREULER, Léo - 91

FREYRE, Gilberto - 39, 45, 74, 75

FRÓES DA FONSECA, Álvaro - 176

FUGIER, Martin - 82 
FUMAROLI, Marc - 52, 53, 55, 58

FURET, François - 53

GALILEI, Galileu - 59

GALVÃO, Ramiz - 163, 164, 169

GALVÃO, Walnice n. - 128

GARDIN, Jean-Claude - 60, 127

GATTINARA, Enrico Castelli - 99, 105

GAULIN, Michel - 36

GAY, Peter - 59, 98

GEMELLI, Giuliana - 55, 92

GENTHILHOMME, Yves - 60, 127

GIDE, André - 31

GIERE, Ronald N. - 60

GILLE, A. - 83

GILLISPIE, Charles Coulston - 90

GINGRAS, Yves - 36

GINZBURG, Carlo - 51, 54, 105

GOETHE, Johann Wolfgang Von - 39, 54, 98

GOFFMAN, Erwing - 21

GOMES, Angela de Castro - 72, 76

GOMES, Sônia de Conti - 58

GOUBIN, M. - 105

GOULEMOT, Jean - 102

GOUNCOURT, Edmond de \& Jules de - 34, 71

GRANJON, Marie-Christine - 25, 40

GRENIER, Jean-Yves - 60, 105

GRIGNON, Claude - 60, 105

GUANABARA, Alcindo - 47

GUILHAUMOU, Jacques - 26, 60

GUIMARÃES, Bernardo - 63

GUIMARÃES, Manoel Luiz Salgado - 33, 34

GURGEL, Luiz do Nascimento - 113, 152

GUSDORF, Georges - 376, 59, 82, 104

HABERMAS, Jürgen - 99

HAECKEL, Ernest Heinrich - 108

HALLEWELL, Laurence - 58
HAROCHE, Claudine - 93, 105

HARTOG, François - 53

HARTT, Charles Frederick - 126

HAYEK, Friedrich von - 58

HEILBRON, J. - 108

HERSANT, Yves - 92

HOCHMAN, Gilberto - 140, 179

HOEHNE, Frederico Carlos - 122, 164

HOLANDA, Sérgio Buarque de - 74, 75, 77

HOMERO - 39

HUGO, Victor - 55

HUMBOLDT, Alexander von - 54

HUME, David - 59

IHERING, Herman von - 113

IHERING, Rodolfo von - 164

JACOBI, Daniel - 60, 127, 128

JACYNA, L. S. - 102

JOPPERT, Maurício - 176

JOÃO DO RIO (Paulo Barreto) - 22, 38, 39, $47,61,66,68,69,70,71,73,129$

JUILLARD, Jacques - 139

KARL, Frederick - 71

KEATING, Peter - 36

KEHL, Renato - 131, 155, 180

KEMPF, Roger - 71

KIERKEGAARD, Sören - 104

KNIGHT, David - 94, 100, 105

KOSELLECK, Reinhart - 25, 26, 27, 83

KOYRÉ, Alexandre - 21

KURY, Lorelai Brilhante - 33, 34, 126

LABORIAU, Ferdinand - 172, 176

LA CAPRA, Dominick - 26

LACERDA, João Batista de - 113

LAET, Carlos de - 145

LA FONTAINE, Jean de -47

LAGRANGE, M-S. - 98

LANDES, D. - 83

LAPLACE, Pierre Simon - 98 
LASTEYRIE, Robert de.- 53

LATOUR, Bruno - 139

LEÃO, Antonio Carneiro - 87

LEÃO, Múcio - 77

LE BON, Gustave - 89

LE DANTEC, Felix - 105

LE GOFF, Jacques - 31

LEITE, Dante Moreira - 67

LEME, Alberto Betim Paes - 18, 164, 178

LEME, Luís Betim Paes - 122

LÉONARD, J. - 109

LEONARDOS, Othon - 176

LEPENIES, Wolf - 102, 103, 104

LE PLAY, Pierre-Guillaume-Frédéric - 116

LESSA, Pedro - 73

LÉVY-LEBLOND, Jean-Marc - 60, 127

LICOPPE, Christian - 60, 127

LIMA, Agostinho José de Souza - 113

LIMA, Alceu Amoroso - 155

LIMA, Henrique Rocha - 113

LIMA, Luiz Costa - 38, 67, 70, 128

LIMA, Manuel de Oliveira - 169, 170

LIMA, Nísia Trindade - 15, 28, 57, 71, 76, $140,175,176,178,179$

LIMOGES, Camille - 36

LIPOVETSKY, G. - 82

LOBO, Bruno Álvares da Silva - 164

LOBO, Laurinda Santos - 47

LOCKE John- 59

LOPES, Júlia - 47

LOPES, Maria Margaret - 15, 17, 39, 109 , $112,126,136$

LOPES, Oscar - 59

LOUIS, Pierre - 32

LOURENÇO FILHO, Manuel Bergström - 178

LOVEJOY, Arthur O. - 24

LÖWY, Ilana - 92, 139

LÖWY, Michael - 40, 81
LUSO, João - 70

LUTZ, Adolfo - 111, 135, 140, 141, 142, 164

MACEDO, Joaquim Manuel de - 63

MACHADO DE ASSIS, Joaquim Maria - 61, $63,66,67,70,72,87,142,150,154$

MACHADO NETO, A. L. - 70

MAGALHÃES, Basílio de - 169

MAGALHÃES, Fernando de - 141, 176

MALLARMÉ, Sthéphane - 71

MANDROU, Robert - 36

MAQUIAVEL, Nicolo - 39

MARQUES, Xavier - 84

MARTIN-FUGIER, Anne - 82

MARTINS, Luciano - 28

MARTINS, Wilson - 67

MARTIUS, Karl Friederich Philipp von - 126

MARX, Karl - 98

MASSARINI, Luísa - 175

MATAGNE, Patrick - 95

MAUPASSANT, Guy de - 34

MAUSS, Marcel - 31

MAYER, Arno J. - 31, 54, 91, 103

MEDEIROS E ALBUQUERQUE, J. J. de Campos da C. de $-47,59,70,73,149,181$

MELLO, Barão Homem de -113

MELLO, Miguel - 70

MELLO LEITÃO, Cândido de - 164, 178

MENDONÇA, Salvador de - 180

MENEZES, Emílio de - 145, 146

MENGER, Pierre-Michel - 60, 105

MENUCCI, Sud - 64, 71

MICELI, Sérgio - 15, 28, 29, 43, 81

MIGUEL-PEREIRA, Lúcia - 34, 64, 67

MOLIÉRE - 118

MONGE, Gaspard - 98

MOREIRA, Álvaro - 71

MOREIRA, Ildeu de C. - 175

MOREIRA, Juliano - 19, 113, 118, 120, 123, $134,140,141,164,173$ 
MORIZE, Henrique - 113, 125, 164, 173, 175

MORSE, Richard - 86

MORTON, Peter - 102

MOSCOSO, Tobias - 176

MOSES, Arthur Alexandre - 164, 172

MOTA, Maria Aparecida Rezende - 34, 67

MOTOYAMA, Shozo - 15

MOTTA, Arthur - 37, 146, 147, 158

MÜLLER, Lauro - 70, 73, 180

MUNFORD, L.- 83

MUNTEAL FILHO, Oswaldo - 58

NAGLE, Jorge - 78, 81

NASCIMENTO, Alfredo - 137

NEEDELL, Jeffrey - 42

NEIVA, Arthur - 123

NETO, Ladislau - 109

NEWTON, Isaac - 59

NIETZSCHE - 104, 105

NORTE, João do - 41

NOVICOW, J. - 97

OLIVEIRA, Eusébio de - 176

ORTIZ, Renato - 83

ORY, Pascal - 25, 26, 31

OTAVIO, Rodrigo (Filho) - 169

PANZA, Marco - 90, 92, 99

PAPINI, G. - 91

PARREIRAS HORTA, Paulo de Figueiredo - 164

PASSOS, Pereira - 42

PASTEUR, Louis - 91, 109, 125, 147

PAUL, Harry W.- 90

PÉCAUT, Daniel - 28

PEDERNEIRAS, Raul - 71

PEDRO II, Dom - 72, 132, 180

PÉGUY, Charles - 31, 93

PEIXOTO, Júlio Afrânio- 22, 45, 64, 65, 70, $71,113,125,130,135,141,143,145$, $146,148,149,150,158,159,167,171$, 180,181

PEREIRA, Dulcídio - 176
PEREIRA, Miguel - 123

PERELMAN, Chaim - 50

PESCE, G-L.- 96

PESSANHA, José Américo - 53, 54

PESTANA, Rangel - 164

PESTRE, Dominique - 174

PETIT, Anne - 108

PEYTARD, Jean - 60, 127, 128

PICCHIO, Luciana Stegagno - 67

PICON, Antoine - 37, 94

PIMENTEL, Figueiredo - 66

PLATÃO - 47, 51, 54

PLUET-DESPATIN, Jacqueline - 43

POCOCK, John - 27

POINCARÉ, Henri - 94, 99, 105, 125, 165

POMBAL, Marquês de - 59

POMIAN, Krzysztof - 24, 31, 36, 59, 99, 103,133

PONT, Jean-Claude - 90, 92, 99

PORTELLA, Joaquim Pinto - 131

PORTER, ROy - 26

PORTO-ALEGRE, Manoel de Araújo - 126

POSNY, J. H. - 86

PROCHASSON, Christophe - 31, 43, 82, 87, 92, 93, 97, 105, 139

PROUST, Marcel - 31

QUEIRÓS, Eça de - 34

QUEIROZ, Maria Isaura Pereira de - 71

QUINTELLA, Arnaldo - 141

QUINTILIANO - 51

RAMOS, Guerreiro - 29

RASMUSSEN, Anne - 31, 92, 93, 97, 99

REDONDO, Garcia - 59

RÉGALDO, Marc - 40

RENAN, Ernest - 34, 91, 108

REY, Alain - 71, 91

RIBAS, Emílio - 140

RIBEIRO, João - 76 
RICHET, Charles - 96, 97, 148

ROCHA, Arnaldo - 172

ROCHA FARIA, Benjamin Antônio da - 113, 138

ROCHA POMBO, José Francisco de - 73

ROCHE, Daniel - 58

ROGER, Jacques - 32, 95

ROLLAND, C. H.- 101, 102

ROLLEMBERG, Marcello - 71

ROMERO, Sílvio - 28, 34, 49, 70, 72, 74, 77, 116,129

ROQUETTE-PINTO, Edgar - 18, 22, 118, $121,122,123,125,126,129,134,135$, $139,140,142,159,164,169,173,175$, $176,177,178,181,187$

ROSSI, Paolo - 92

ROUSSEAU, G. S. - 101, 102

SÁ, Dominichi Miranda de - 175, 176, 178

SAINT-HILAIRE, Auguste de - 126

SALIBA, Elias Thomé - 45, 46, 177

SALOMON-BAYET, Claire - 92

SAMAIN, Alberto - 180

SAMPAIO, Gabriela dos Reis - 110

SANTIAGO, Silviano - 76

SANTOS, Afonso Carlos Marques dos - 33, $37,40,42,58,59,60$

SANTOS, M. P. de Oliveira - 81

SANTOS, Wanderley Guilherme dos - 29, $30,57,124$

SARAIVA, Mário - 176

SAUSSURE, L de - 100

SAYRE, Robert - 40, 81

SCHILLER, Friedrich von - 54

SCHLANGER, Judith E.- 97

SCHVARZMAN, Scheila - 178

SCHWARCZ, Lília K. Moritz - 28, 109

SCHWARTZMAN, Simon - 15, 28

SCHWARZ, Roberto - 27, 28

SEIDL, Carlos - 113, 137, 138
SENNA, Homero - 158

SENNETT, Richard - 52, 54, 72, 93, 101

SERGENT, Edmond - 140

SERRANO, Jonatas - 141, 167

SEVCENKO, Nicolau - 42, 43, 72, 84, 128

SHAFFER, Simon - 127

SHAKESPEARE, William - 39, 47

SHAPIN, Steven - 127

SHEETS-PYENSON, S. - 174

SHELLEY, Mary - 92

SIGRIST, René - 60, 127

SILVA, Álvaro Alberto da - 113

SILVA, Dias Ferreira - 132

SILVA, Moacir - 84

SIMMEL, Georg - 82, 84

SIRINELLI, Jean-François - 24, 25, 31, 54, 87,93

SMITH, Adam - 98

SMITH, John H. - 54

SNOW, C. P. - 105

SÓCRATES - 47

SODRÉ, Nelson Werneck.- 44

SÓFOCLES - 39

SOUZA, Inglês de - 47

SOUZA, Mário de - 173

SOUZA PITANGA, Antonio Ferreira de $112,113,169$

SPENCER, Herbert - 108

SPIX, Johann Baptist - 126

STAROBINSKI, Jean - 40, 42

STENDHAL (Marie Henri Beyle)- 34

STEPAN, Nancy - 15

STOEKL, Allan - 31

SÜSSEKIND, Flora - 43, 126

TÁCITO - 161

TAINE, Hippolyte - 34, 55, 91, 101, 108

TÁVORA, Franklin - 63

TEIXEIRA, Anísio - 178 
THOMPSON, E. P. - 83

TIGRE, Bastos - 59, 71

TORRES, Alberto - 73, 74, 116, 129

TORRES, Alberto de Seixas Martins - 168

TORRES, Antônio - 49, 50

TORRES, Heloísa Alberto - 176, 178

TRAUTMANN, Joanne - 102

TREBITSCH, Michel - 25, 40

VELOSO, Antônio Leão - 155

VELLOSO, Mônica Pimenta - 70, 72

VENÂNCIO FILHO, Alberto - 23

VENÂNCIO FILHO, Francisco - 176, 178

VENTURA, Roberto - 34, 43, 61, 67, 70, 72

VERÍSSIMO, José - 34, 40, 61, 62, 63, 64, $65,66,67,70,72,77,85,130$

VERLAINE, Paul - 55

VERNEY, Luís Antonio - 59, 60

VIANNA, Joaquim - 41, 77, 80

VIANNA, Luiz Werneck - 86
VIANNA, Francisco José de Oliveira - 75, 162,169

VIEIRA, Arnaldo Damasceno - 73

VIEIRA, Frei Domingos - 20, 137

VIEIRA, Padre Antonio - 39, 84, 125

VIDIER, Alexandre - 53

VILHENA, Luís Rodolfo - 28, 71

VIRGÍLIO - 39

VIVEIROS DE CASTRO, Augusto Olympio $-168$

VOVELLE, Michel - 36

WALLENBORN, Grégoire - 100

WEBER, Max - 31, 92

WILDE, Oscar - 71

WILLIAMS, P. - 92

WILLIAMS, R. - 102

WINOCK, Michel - 31

ZALUAR, Augusto Emílio - 126, 141

ZOLA, Émile - 31, 34, 47, 72, 91 


\author{
Formato: $16 \times 23 \mathrm{~cm}$ \\ Tipologia: Marigold e Carmina Lt BT \\ Papel: Pólen BOLD $70 \mathrm{~g} / \mathrm{m}^{2}$ (miolo) \\ Cartão Supremo $250 \mathrm{~g} / \mathrm{m}^{2}$ (capa) \\ Fotolitos: Laser vegetal. (miolo) \\ Engenho e Arte Editoração Gráfica Ltda. (capa) \\ Impressão e acabamento: Imprinta Express Gráfica e Editora Ltda. \\ Rio de Janeiro, agosto de 2006.
}

Não encontrando nossos títulos em livrarias, contactar a EDITORA FIOCRUZ:

Av. Brasil, 4036 - 1 andar - sala 112 - Manguinhos

21040-361 - Rio de Janeiro - RJ

Tel.: (21) 3882-9039 e 3882-9041

Telefax: (21) 3882-9007 
